Universidade de Brasília

Faculdade UnB Planaltina

Programa de Pós-Graduação em Gestão Pública

\title{
QUALIDADE DO ENSINO MÉDIO NA PERCEPÇÃO DE DUAS COMUNIDADES ESCOLARES: subsídios para gestores públicos
}

\section{Petra Kaari Fernandes}

\section{Brasília-DF}




\section{Petra Kaari Fernandes}

\section{QUALIDADE DO ENSINO MÉDIO NA PERCEPÇÃO DE DUAS COMUNIDADES ESCOLARES: subsídios para gestores públicos}

Dissertação apresentada ao Programa de PósGraduação em Gestão Pública da Faculdade UnB Planaltina (FUP) no Curso de Mestrado Profissional em Gestão Pública como requisito parcial para obtenção do título de Mestre em Gestão Pública.

Orientadora: Prof. $^{\mathrm{a}}$ Dr. $^{\mathrm{a}}$ Luciana de Oliveira Miranda

\section{Brasília-DF}


Ficha catalográfica elaborada automaticamente, com os dados fornecidos pelo(a) autor(a)

Kaari Fernandes, Petra
QUALIDADE DO ENSINO MÉDIO NA PERCEPÇÃo DE DUAS
COMUNIDADES ESCOLARES: subsidios para gestores
públicos / Petra Kaari Fernandes; orientador Luciana
de Oliveira Miranda. -- Brasilia, 2017.
194 p.
Dissertação (Mestrado - Mestrado Profissional em
Gestão Pública) -- Universidade de Brasilia, 2017.
1. educação. 2. qualidade educacional. 3. Ensino
Médio. I. de Oliveira Miranda, Luciana, orient. II.
Titulo.




\section{Petra Kaari Fernandes}

\section{QUALIDADE DO ENSINO MÉDIO NA PERCEPÇÃO DE DUAS COMUNIDADES ESCOLARES: subsídios para gestores públicos}

Dissertação de Mestrado Profissional apresentada ao Programa de Pós-Graduação em Gestão Pública da Faculdade UnB de Planaltina como requisito parcial para obtenção do título de Mestre em Gestão Pública.

\section{BANCA EXAMNADORA}

Professora Doutora Luciana de Oliveira Miranda

Universidade de Brasília - Presidente

Professor Doutor Geraldo Eustáquio Moreira

Universidade de Brasília - Membro Interno

Professor Doutor José Francisco Soares

Universidade Federal de Minas Gerais - Membro Externo

Professor Doutor Luiz Honorato da Silva Júnior

Universidade de Brasília - Membro Suplente

Brasília-DF, 17 de fevereiro de 2017. 
Dedico esse trabalho à minha querida filha Lorena e a todas as crianças e jovens, a quem desejo um Brasil mais ético e igualitário.

E a todos os profissionais da educação que, com criatividade, persistência e compromisso, buscam excelência em seus trabalhos. 


\section{Agradecimentos}

A Deus, pela oportunidade da vida (novamente);

Aos meus pais pela educação dada e a toda a família, pelo apoio e compreensão;

À minha querida e amada filha Lorena, em quem me inspirei para realizar esse trabalho;

Ao Édison, pelas contribuições no campo internacional e por todo suporte;

À Leilane, que já é da família;

A todos os amigos e amigas, em especial ao Mendes, pelas contribuições sempre valiosas;

A todos que, prontamente e pacientemente, colaboraram com a pesquisa;

Aos servidores do MEC, INEP e da Secretaria de Educação do GDF, que auxiliaram e disponibilizaram dados e informações para esse estudo;

À equipe da SNJ, pelo apoio e compreensão;

Ao FNDE e à UnB, pela oportunidade de aperfeiçoamento;

A todos os docentes do PPGP que ampliaram minha visão, em especial à minha Orientadora, por seu profissionalismo, disponibilidade, liberdade, confiança, apoio constante e leveza com que conduziu o meu processo de pesquisa e redação.

E não por último, a todos os colegas e amigos do mestrado, pelo incentivo e apoio mútuo sempre, aprendi muito com todos vocês!!

O meu MUITO OBRIGADA!! 


\section{RESUMO}

O cenário do Ensino Médio no Brasil é desafiador. Segundo o Ministério da Educação, apenas $58 \%$ dos jovens entre 15 e 17 anos estão nessa etapa de ensino e, em termos de proficiência, "mais de $75 \%$ dos alunos estão abaixo do esperado, e por volta de $25 \%$ encontram-se no nível zero, ou seja, mais de dois milhões de jovens não conseguem aplicar os conhecimentos adquiridos nas disciplinas de português e matemática" (BRASIL, 2016c, p. 2). Frente a essa conjuntura, como melhorar a qualidade educacional e como agir em termos de política pública? A partir de estudo de caso múltiplo, esse trabalho visa propiciar subsídios a gestores públicos que atuam na área educacional. Para isso, primeiramente, recorreu-se à legislação e à literatura nacional e internacional com vistas a se compreender a respeito do conceito sobre qualidade em educação e dos elementos que a compõem. Com essa base teórica foi-se a campo investigar a percepção de duas comunidades escolares sobre educação de qualidade e os desafios para a sua concretização. Participaram da pesquisa diretores, coordenadores pedagógicos, docentes e estudantes de duas escolas públicas regulares de Brasília-DF, as quais obtiveram as melhores notas, entre seus pares, no Exame Nacional do Ensino Médio (ENEM) edições 2014 e 2015. Dessa forma, o estudo buscou responder o seguinte problema de pesquisa: Quais são os principais desafios para a implementação de um Ensino Médio de qualidade? Como resultado observou-se que a maioria dos profissionais de ambas as escolas tem como conceito de educação de qualidade a formação integral do indivíduo, voltada não só para o mercado de trabalho, mas para o exercício da cidadania. Entre os principais desafios, sugestões e demandas, apontados pelos profissionais para a melhoria educacional estão: tornar a educação prioridade dentro dos governos federal e distrital; tornar a escola atual e atrativa aos estudantes; flexibilizar o currículo de modo a atender o objetivo de vida do estudante, o qual pode ser ensino técnico, superior ou profissão não alinhada ao mundo acadêmico, como evidenciado na pesquisa; fortalecer e investir no Ensino Médio, mas também no ensino fundamental; aumentar os recursos financeiros e repassá-los tempestivamente; ampliar a autonomia no gasto e na gestão de pessoas, assim como melhorar a área administrativa das escolas, tanto em termos de pessoal capacitado, como de sistemas informatizados; estabelecer boa comunicação entre todos os envolvidos; diminuir a rotatividade de pessoal; valorizar a classe docente financeiramente e em termos de participação na elaboração das políticas públicas; capacitar o professorado em tecnologia; capacitar o coordenador pedagógico para a função; diminuir o número de alunos por sala; realizar pré-diagnóstico do aluno para verificar seus conhecimentos pregressos com vistas a atendê-lo de forma mais apropriada; aperfeiçoar o sistema de aulas, de avaliação e o reforço escolar com o objetivo de mitigar deficiências do ensino fundamental; aprimorar o ambiente tecnológico, incluindo internet de alta velocidade; melhorar a temperatura das salas de aula, pois o telhado é de metal. Para os diretores, um dos principais desafios refere-se à gestão de pessoas, tanto em termos de alinhamento de percepção com os coordenadores pedagógicos eleitos pelos docentes, como em relação à resistência de professores em aperfeiçoar a didática e em aceitar novas práticas. Do ponto de vista geral, foram destacadas a necessidade de se melhorar o ensino fundamental e a urgência em se obter apoio das famílias no fortalecimento da escola pública, pois não basta uma escola que eduque, motive e discipline, se não há o reforço positivo por parte das famílias no empoderamento da equipe escolar e na orientação dos filhos para o futuro. A partir da pesquisa, foi possível constatar que sem a atuação conjunta, efetiva e determinada de todos os envolvidos: poder público, profissionais da educação, estudantes, famílias e sociedade em geral, a melhoria da qualidade educacional será sempre pontual e precária.

Palavras-chaves: educação, qualidade educacional, Ensino Médio. 


\begin{abstract}
The picture of high school education in Brazil is challenging. According to the Ministry of Education, only $58 \%$ of teenagers aged between 15 and 17 are in this stage of education and, in terms of proficiency, "over $75 \%$ of students are below the expected level, and around $25 \%$ are at level zero, i.e. more than 2 million young people have fail to apply the knowledge they acquired in Portuguese and Mathematics" (BRASIL, 2016c, p. 2). In light of this situation, how would it be possible to improve educational quality and to translate it in terms of public policy? Based on a multiple case study, the present work aims to provide subsidies for decision-making of public officials working in the education field. For this, firstly the legislation and the national and international literature on the topic were analyzed in order for the concept of quality in education and the elements that make it up to be understood. On this theoretical basis a field research was carried out to investigate the understanding of two school communities on quality of education and the challenges to its implementation. School principals, pedagogical coordinators, teachers and students from two regular public schools in Brasilia participated in the research. Both schools obtained the best rates among their peers in the 2014 and 2015 National High School Exam (ENEM). Therefore, the study sought to answer the following research problem: what are the main challenges for the implementation of a quality high school education? It was seen that most of the education practitioners from both schools have as a concept of quality education an all-round formation of the individual, designed not only for the labour market, but also for participating fully in civic life. Among the main challenges, the following suggestions and demands singled out by these education practitioners for educational improvement can be highlighted: making education a priority at federal and state level; making schools modern/contemporary and attractive to students; making the curriculum more flexible in order to meet the students' goals in life, which may be connected to vocational education, or higher education, or to profession not necessarily aligned to the academic world, as shown in the research; strengthening and investing in high school education, but also in middle schools; increasing financial resources and transferring them promptly; increasing the autonomy in spending and management of school personnel; improving the administrative field, both in terms of personnel and computerized systems; assuring good communication among people; decreasing staff turnover; valuing teachers both financially and in terms of participation in public policy-making; empowering teachers in terms of technology; qualifying the pedagogical coordinator; decreasing the number of students per class; pre-assessing students previous knowledge in order to serve them in a more appropriate way; improving the system of teaching, school evaluation and reinforcement classes in order to mitigate shortcomings in elementary schools; advancing the technological environment, including high speed internet; improving schools facilities such as classroom temperature. As reported by the school principals, one of the main challenges refers to people management, both in terms of alignment of perception with the pedagogical coordinators and teachers' resistance to improving teaching and accepting new practices. From a general point of view, the need for improvement in basic education and the urgency in obtaining support from families for the purpose of strengthening public schools were highlighted. That's because a school that educates, motivates and disciplines may not be enough if there is no positive reinforcement by families with a view to empower school practitioners and to guide children for the future. From the research it was found that without joint, effective and determined action from all those involved, that is government, education practitioners, students, families and society as a whole, improvement in quality education will always be ephemeral and precarious.
\end{abstract}

Keywords: education, education quality, high school. 


\section{RESUMEN}

La escena de la enseñanza media en Brasil es desafiante. Según el Ministerio de Educación, sólo el 58\% de los jóvenes entre 15 y 17 años están en esta etapa de la educación y, en términos de competencia, "más del $75 \%$ de los estudiantes están por debajo de lo esperado, y alrededor del $25 \%$ están en a nivel cero, es decir, más de 2 millones de jóvenes no aplican los conocimientos adquiridos en las disciplinas de portugués y matemáticas" (BRASIL, 2016c, p. 2). ¿Ante esta situación, cómo mejorar la calidad educativa y actuar en términos de política pública? A partir de un estudio de caso múltiple, este trabajo tiene como objetivo proporcionar subsidios a gestores públicos que trabajan en el área educativa. Con este propósito, primeramente se recurrió a la legislación y a la literatura nacional e internacional con el fin de entender el concepto de calidad en la educación y en los elementos que la componen. Con esta base teórica, se fue a campo para investigar la percepción de dos comunidades escolares sobre calidad y los retos para su implementación. Participaron en la investigación directores, coordinadores pedagógicos, maestros y alumnos de dos escuelas públicas regulares de Brasilia-DF que obtuvieron las mejores calificaciones entre sus pares, en las ediciones 2014 y 2015 del Examen Nacional de la Enseñanza Media (ENEM). De esta manera, el estudio intentó responder al siguiente problema de investigación: ¿Cuáles son los principales desafíos para la implementación de una escuela de alta calidad? Como resultado, se observó que la mayoría de los profesionales de ambas escuelas tiene como concepto de calidad de la educación la formación integral del individuo, dedicada no sólo al mercado de trabajo, sino al ejercicio de la ciudadanía. Entre los principales retos, propuestas y demandas señaladas por los profesionales para la mejora educativa están: hacer de la educación una prioridad dentro de los gobiernos federal y local; hacer de la escuela actual algo atractivo a los estudiantes; hacer que el plan de estudios sea más flexible con el fin de cumplir con el objetivo de la vida de los estudiantes, que puede ser formación técnica, educación superior o no alineada con el mundo académico, como se evidencia en la investigación; fortalecer e invertir en la escuela secundaria, pero también en la primaria; incrementar los recursos financieros y transferirlos en el plazo previsto; ampliar la autonomía de gasto y gestión de personal, así como mejorar el área administrativa de las escuelas, tanto en términos de personal competente con respecto a los sistemas computarizados; establecer buena comunicación entre todos los involucrados; disminuir la rotación de personal; mejorar el cuerpo docente financieramente y en términos de participación en la elaboración de políticas públicas; capacitar al profesorado en materia de tecnología; capacitar al coordinador pedagógico para la función; disminuir el número de alumnos por clase; realizar prediagnóstico del alumno para verificar sus conocimientos regreso a fin de atenderlo de modo más conveniente; perfeccionar el sistema de clases, de evaluación y el refuerzo escolar con el fin de mitigar las deficiencias de la escuela primaria; mejorar el entorno tecnológico, incluyendo alta velocidad a internet; mejorar la temperatura de las aulas en las que el techo es de metal. Para los directores, uno de los principales retos que se destaca se refiere a la gestión de personas, tanto en términos de alineamiento con los coordinadores pedagógicos elegidos por los profesores como en relación a la resistencia de los docentes para mejorar la didáctica y a aceptar nuevas prácticas. Desde un punto de vista general, se destacó la necesidad de mejorar la educación primaria y la urgencia en obtener el apoyo de las familias en el fortalecimiento de la escuela pública, pues no basta una escuela que educa, que motiva y que discipline si no hay ningún refuerzo positivo de parte de las familias en relación al empoderamiento del equipo escolar y a la orientación de los niños para el futuro. De la investigación realizada, se constató que sin una acción conjunta, eficaz y decidida de todos los involucrados, es decir, el gobierno, los profesionales de la educación, los estudiantes, las 
familias y la sociedad como un todo, la mejoría de la calidad educativa siempre será puntual y precaria.

Palabras: educación, calidad educativa, enseñanza secundaria. 


\section{LISTA DE FIGURAS}

Figura 1: Um referencial para entender qualidade da educação do ponto de vista da

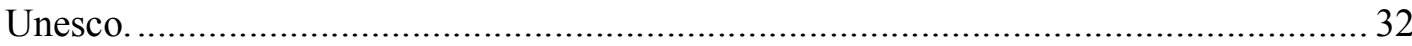

Figura 2: Estrutura para a compreensão da qualidade da educação em África................ 33

\section{LISTA DE GRÁFICOS}

Gráfico 1: Taxa de analfabetismo das pessoas de 15 anos ou mais de idade, segundo as Grandes Regiões no Brasil - 2013-2014 45

Gráfico 2: Taxa de analfabetismo das pessoas de 15 anos ou mais de idade, segundo os grupos de idade - Brasil - 2013-2014 45

Gráfico 3: Taxa de analfabetismo funcional das pessoas de 15 anos ou mais de idade, segundo as Grandes regiões - Brasil - 2013-2014 ................................................. 46

Gráfico 4: Distribuição percentual das pessoas de 25 anos ou mais de idade, segundo o nível de instrução - Brasil - 2013-2014

Gráfico 5: Áreas que deveriam ser enfatizadas na escola A na percepção de docentes, coordenação pedagógica e estudantes. 109

Gráfico 6: Áreas que deveriam ser enfatizadas na escola B na percepção de docentes, coordenação pedagógica e estudantes 109

Gráfico 7: O que precisa ser feito para melhorar a qualidade do Ensino Médio na escola A na percepção de estudantes, docentes e coordenação pedagógica. 118

Gráfico 8: O que precisa ser feito para melhorar a qualidade do Ensino Médio na escola B na percepção de estudantes, docentes e coordenação pedagógica. 118 


\section{LISTA DE QUADROS}

Quadro 1: Ênfases no debate sobre qualidade educacional conforme estágios de

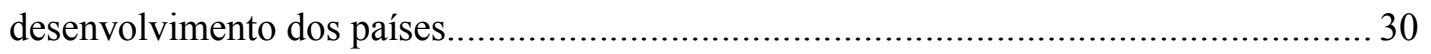

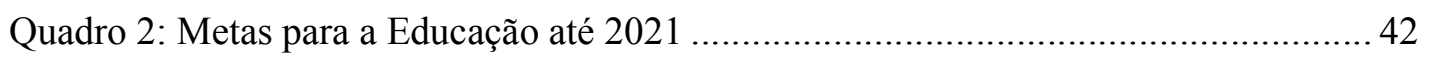

Quadro 3: Categorias de adequação da formação dos docentes em relação à disciplina que

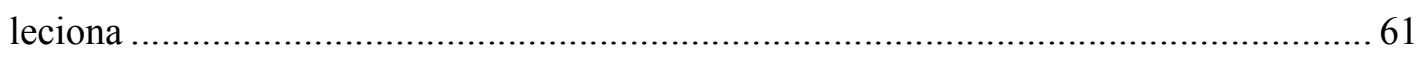

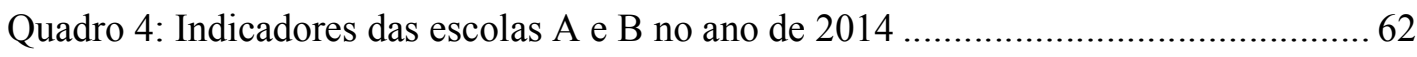

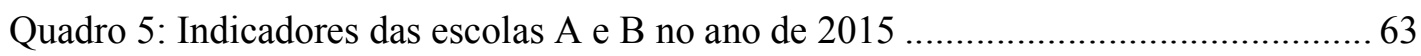

Quadro 6: Recursos financeiros recebidos pela Escola A no período de 2012 a 2016.... 69

Quadro 7: Perfil da Coordenação Pedagógica da Escola A ........................................ 72

Quadro 8: Docentes da escola A, anos de experiência na área................................... 73

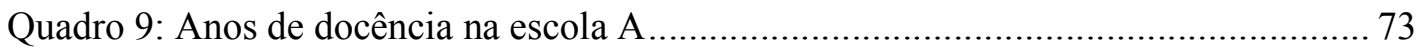

Quadro 10: Área de atuação dos professores que participaram da pesquisa na escola A.73

Quadro 11: Formação acadêmica dos docentes da escola A participantes da pesquisa

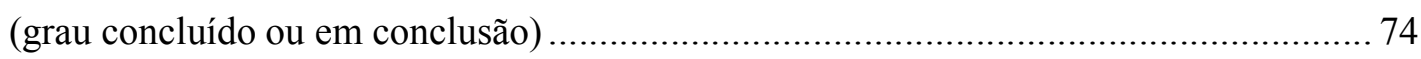

Quadro 12: Composição do Índice de Adequação da Formação Docente da Escola A no

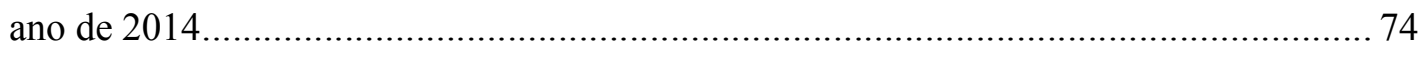

Quadro 13: Composição do Índice de Adequação da Formação Docente da Escola A no

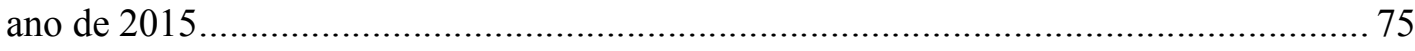

Quadro 14: Número de capacitações realizadas nos últimos 2 (dois) anos pelos docentes

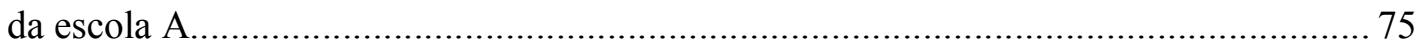

Quadro 15: Escola A: turmas, alunos por turma, série e turno, no período de 2012 a 2015.

Quadro 16: Gênero do público discente da Escola A ................................................ 78 
Quadro 17: Porcentagem de estudantes da escola A que trabalham, por gênero 78

Quadro 18: Carga horária média de trabalho semanal do público discente ativo da escola A, conforme gênero. 79

Quadro 19: Percentagem de ocupação do público discente da escola A por série escolar e gênero. 79

Quadro 20: Formação escolar de pais ou responsáveis do público discente da escola A. 79 Quadro 21: Escola A - relação entre formação de pais ou responsáveis e filhos que trabalham 80

Quadro 22: Recursos financeiros recebidos pela Escola B no período de 2012 a 2016... 86

Quadro 23: Perfil da Coordenação Pedagógica da Escola B 90

Quadro 24: Docentes da escola B, anos de experiência na área .................................... 91

Quadro 25: Quantos anos atuam na escola B 91

Quadro 26: Área de atuação dos professores que participaram da pesquisa na escola B.92 Quadro 27: Formação acadêmica (grau concluído ou em conclusão) dos docentes participantes da pesquisa da escola $\mathrm{B}$ 92

Quadro 28: Composição do Índice de Adequação da Formação Docente na Escola B em 2014 92

Quadro 29: Composição do Índice de Adequação da Formação Docente da Escola B em 2015. 93

Quadro 30: Número de capacitações realizadas nos últimos 2 (dois) anos pelos docentes da escola B. 93

Quadro 31: Escola B: turmas, alunos por turma, série e turno, no período de 2012 a 2015.

Quadro 32: Gênero do público discente da Escola B. 96

Quadro 33: Porcentagem de estudantes da escola B que trabalham, por gênero e turno.. 97 
Quadro 34: Carga horária média de trabalho semanal do público discente ativo da escola $\mathrm{B}$, conforme gênero. 97

Quadro 35: Carga horária média de trabalho semanal do público discente do matutino da escola B, conforme gênero. 98

Quadro 36: Carga horária média de trabalho semanal do público discente do noturno da escola $\mathrm{B}$, conforme gênero. 98

Quadro 37: Porcentagem de ocupação do público discente do matutino da escola B, por série escolar. 98

Quadro 38: Formação escolar de pais ou responsáveis do público discente da escola B. 99 Quadro 39: Escola B - relação entre formação de pais ou responsáveis e filhos que trabalham.

Quadro 40: Percepção da comunidade da Escola A sobre a correlação entre sucesso no ENEM e a qualidade da educação ofertada. 105

Quadro 41: Percepção da comunidade da escola B sobre a correlação entre sucesso no ENEM e a qualidade da educação ofertada. 105

Quadro 42: Áreas que deveriam ser enfatizadas na percepção das comunidades da Escola A e da Escola B 110

Quadro 43: Percepção das comunidades escolares sobre a necessidade de reforço ou promoção de atividades extracurriculares sobre os temas: autoconhecimento, projeto de vida e solidariedade.

Quadro 44: Regularidade com que a escola incentiva os alunos a buscar um futuro melhor, superar desafios, ser perseverante nos seus objetivos, cooperativo, criativo, inovador, na percepção das comunidades escolares.

Quadro 45: Regularidade com que a escola A incentiva os alunos, na percepção dos estudantes, por gênero e série. 114

Quadro 46: Regularidade com que a escola B incentiva os alunos, na percepção dos estudantes, por gênero e série. 
Quadro 47: O que precisa ser feito para melhorar a qualidade do Ensino Médio na percepção das comunidades das escolas A e B.

119

Quadro 48: Percepção das comunidades escolares sobre a necessidade de se promover um ambiente educativo mais acolhedor, que favoreça o bom relacionamento entre todos. . 120

Quadro 49: Grau de satisfação dos estudantes com a qualidade do ensino ofertado pela escola A, geral e por gênero.

Quadro 50: Gostam de trabalhar na escola A 121

Quadro 51: Grau de satisfação dos estudantes com a qualidade do ensino ofertado pela escola $\mathrm{B}$, geral e por gênero 123

Quadro 52: Gostam de trabalhar na escola B.

Quadro 53: Percepção das comunidades escolares sobre aspectos pedagógicos. 125

Quadro 54: Percepção das comunidades escolares no tocante à necessidade de melhoria da forma avaliativa dos alunos e do reforço escolar. 127

Quadro 55: Percepção das comunidades escolares no tocante à necessidade de melhoria da gestão e de criação de espaços de discussão sobre regras de disciplina e encaminhamentos 128

Quadro 56: Percepção das comunidades escolares no tocante à necessidade de melhoria da formação docente.

Quadro 57: Percepção das comunidades escolares no tocante à necessidade de melhoria do material de ensino e da infraestrutura escolar. 130

Quadro 58: Fatores que dificultam a melhoria educacional na percepção da comunidade da escola A no quesito Políticas Públicas.

Quadro 59: Demandas e sugestões para melhoria da educação na percepção da comunidade da escola A em relação ao quesito Políticas Públicas.

Quadro 60: Fatores que dificultam a melhoria educacional na percepção da comunidade da escola B no quesito Políticas Públicas. 
Quadro 61: Demandas e sugestões para melhoria da educação na percepção da comunidade da escola B em relação ao quesito Políticas Públicas.

Quadro 62: Demandas e sugestões para melhoria da educação na percepção das comunidades escolares A e B em relação ao quesito Políticas Públicas. 140

Quadro 63: Fatores que dificultam a melhoria educacional, na percepção da comunidade da escola A, no quesito Planejamento e Gestão Escolar.

Quadro 64: Demandas e sugestões para melhoria da educação na percepção da comunidade da escola A em relação ao quesito Planejamento e Gestão Escolar.

Quadro 65: Fatores que dificultam a melhoria educacional na percepção da comunidade da escola B no quesito Planejamento e Gestão Escolar. 143

Quadro 66: Demandas e sugestões para melhoria da educação na percepção da comunidade da escola B em relação ao quesito Planejamento e Gestão Escolar. 145

Quadro 67: Fatores que dificultam a melhoria educacional na percepção das comunidades escolares A e B em relação ao quesito Planejamento e Gestão Escolar. 146

Quadro 68: Demandas e sugestões para melhoria da educação na percepção das comunidades escolares A e B em relação ao quesito Planejamento e Gestão Escolar ... 146

Quadro 69: Fatores que dificultam a melhoria educacional na percepção da comunidade da escola A no quesito Coordenação e Prática Pedagógica. 147

Quadro 70: Demandas e sugestões para melhoria da educação na percepção da comunidade da escola A em relação ao quesito Coordenação e Prática Pedagógica. .... 148

Quadro 71: Fatores que dificultam a melhoria educacional na percepção da comunidade da escola B no quesito Coordenação e Prática Pedagógica

Quadro 72: Demandas e sugestões para melhoria da educação na percepção da comunidade da escola B em relação ao quesito Coordenação e Prática Pedagógica. .... 151

Quadro 73: Fatores que dificultam a melhoria educacional na percepção das comunidades escolares A e B em relação ao quesito Coordenação e Prática Pedagógica 152 
Quadro 74: Demandas e sugestões para melhoria da educação na percepção das comunidades escolares A e B em relação ao quesito Coordenação e Prática Pedagógica.

Quadro 75: Fatores que dificultam a melhoria educacional na percepção da comunidade da escola A no quesito Infraestrutura e Recursos. 153

Quadro 76: Demandas e sugestões para melhoria da educação na percepção da comunidade da escola A em relação ao quesito Infraestrutura e Recursos. 154

Quadro 77: Fatores que dificultam a melhoria educacional na percepção da comunidade da escola B no quesito Infraestrutura e Recursos. 154

Quadro 78: Demandas e sugestões para melhoria da educação na percepção da comunidade da escola B em relação ao quesito Infraestrutura e Recursos. 155

Quadro 79: Demandas e sugestões para melhoria da educação na percepção das comunidades escolares A e B em relação ao quesito Infraestrutura e Recursos. 156

Quadro 80: Fatores que dificultam a melhoria educacional na percepção da comunidade da escola A no quesito Professores e condições de trabalho.

Quadro 81: Demandas e sugestões para melhoria da educação na percepção da comunidade da escola A em relação ao quesito Professores e condições de trabalho.... 157

Quadro 82: Fatores que dificultam a melhoria educacional na percepção dos coordenadores da escola B no quesito Professores 158

Quadro 83: Demandas e sugestões para melhoria da educação na percepção da comunidade da escola B em relação ao quesito Professores. 159

Quadro 84: Fatores que dificultam a melhoria educacional na percepção das comunidades escolares A e B em relação ao quesito Professores e Condições de Trabalho. 160

Quadro 85: Demandas e sugestões para melhoria da educação na percepção das comunidades escolares A e B em relação ao quesito Professores e Condições de Trabalho 160

Quadro 86: Fatores que dificultam a melhoria educacional na percepção da comunidade da escola A no quesito Alunos 161 
Quadro 87: Fatores que influenciam na melhoria da educação na percepção da comunidade da escola A em relação ao quesito Alunos. 162

Quadro 88: Fatores que dificultam a melhoria educacional na percepção da comunidade da escola B no Alunos. 163

Quadro 89: Fatores que influenciam na melhoria da educação na percepção da comunidade da escola B em relação ao quesito Alunos. 164

Quadro 90: Fatores que dificultam a melhoria educacional na percepção das comunidades escolares A e B em relação ao quesito Alunos. 164

Quadro 91: Demandas e sugestões para melhoria da educação na percepção das comunidades escolares A e B em relação ao quesito Alunos. 165

Quadro 92: Fator que dificulta a melhoria educacional na percepção de docente da escola A no quesito Família. 165

Quadro 93: Fatores que propiciam a melhoria da educação na percepção da comunidade da escola A em relação ao quesito Família. 166

Quadro 94: Fatores que dificultam a melhoria educacional na percepção da comunidade da escola B no quesito Família. 167

Quadro 95: Fatores que propiciam a melhoria da educação na percepção da comunidade da escola B em relação ao quesito Família. 167

Quadro 96: Fatores que dificultam a melhoria educacional na percepção das comunidades escolares A e B em relação ao quesito Família. 168 


\section{LISTA DE ABREVIATURAS}

APAAM - Associação de Pais, Alunos, Auxiliares e Mestres

APM - Associação de Pais e Mestres

E1; E2 - Entrevista 1; Entrevista 2

CAQ - Custo Aluno Qualidade

CAQi - Custo Aluno Qualidade Inicial

CEB - Câmara de Educação Básica

CNE - Conselho Nacional de Educação

DF - Distrito Federal

EAPE - Escola de Aperfeiçoamento dos Profisssionais da Educação

ENEM - Exame Nacional do Ensino Médio

FNDE - Fundo Nacional de Desenvolvimento da Educação

FUNDEF - Fundo de Manutenção e Desenvolvimento do Ensino Fundamental e de

Valorização do Magistério

GDF - Governo do Distrito Federal

IBGE - Instituto Brasileiro de Geografia e Estatística

IDEB - Índice de Desenvolvimento da Educação Básica

Inse - Indicador de Nível Socioeconômico

INEP - Instituto Nacional de Estudos e Pesquisas Educacionais Anísio Teixeira

IPE - Indicador de Permanência na Escola

LDB - Lei de Diretrizes e Bases da Educação Nacional

MEC - Ministério da Educação

OCDE - Organização para a Cooperação e Desenvolvimento Econômico

ODS - Objetivos de Desenvolvimento Sustentável

PAS - Programa de Avaliação Seriada da Universidade de Brasília

PDAF - Programa de Descentralização Administrativa e Financeira

PDE - Plano de Desenvolvimento da Educação

PNAD - Pesquisa Nacional por Amostra de Domicílios

PNE - Plano Nacional de Educação

PNEM - Pacto Nacional pelo fortalecimento do Ensino Médio

PI - Projeto Interdisciplinar

PIBID - Programa Institucional de Bolsas de Iniciação à Docência

PPP - Projeto Político Pedagógico

PRC - Projeto de Redesenho Curricular

UnB - Universidade de Brasília

UNESCO - Organização das Nações Unidas para a Educação, a Ciência e a Cultura UNICEF - Fundo das Nações Unidas para a Infância 


\section{SUMÁRIO}

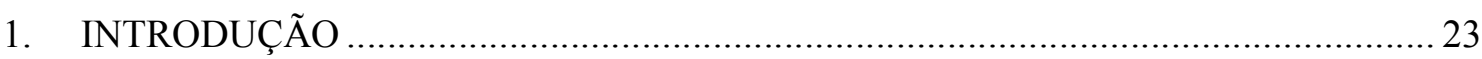

1.1. Formulação do Problema de Pesquisa........................................................................ 24

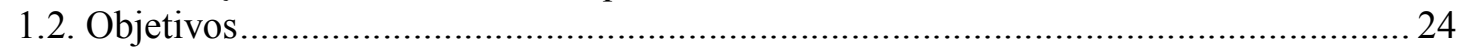

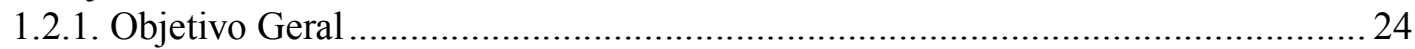

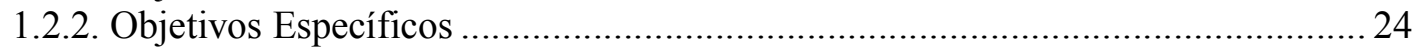

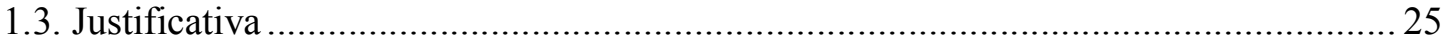

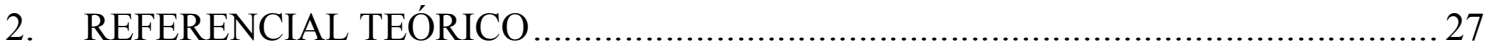

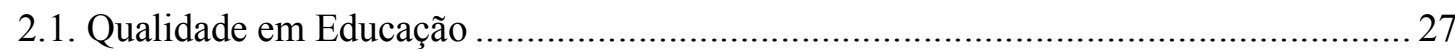

2.1.1. Concepções de qualidade em educação no Brasil e no Mundo ...............................22

2.1.2. Qualidade da educação na legislação brasileira ..................................................... 40

2.2. Contexto da Educação e do Ensino Médio no Brasil ................................................... 44

2.3. Qualidade da educação: das concepções ao desafio da implementação ........................ 48

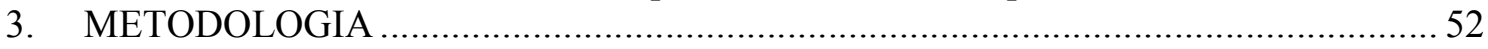

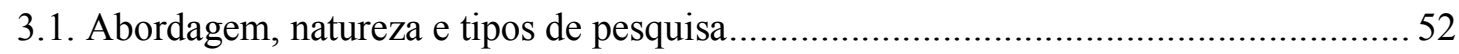

3.2. Critérios de seleção das escolas pesquisadas ...........................................................5 54

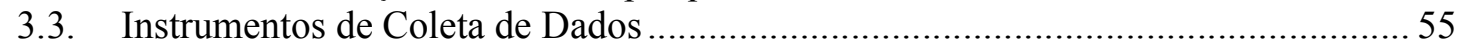

3.4. Análise de Dados ................................................................................................ 57

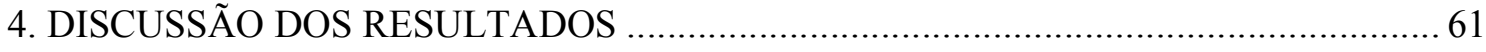

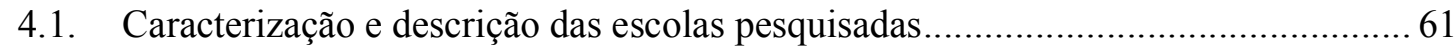

4.2. Educação de qualidade na percepção das comunidades pesquisadas........................ 100

4.2.1. Relação entre Educação de qualidade e ENEM. ……………………............. 104

4.2.2. Formação integral do indivíduo - áreas a serem aperfeiçoadas nas escolas

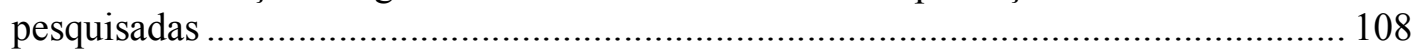

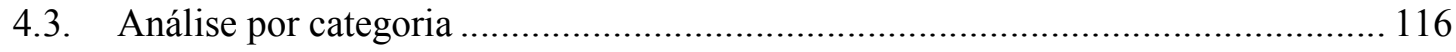

4.3.1. Ambiente educativo/clima organizacional................................................. 120

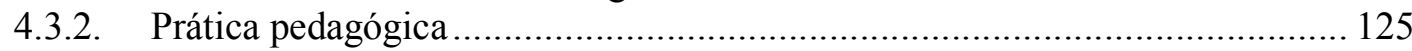

4.3.3. Avaliação do estudante e reforço escolar...................................................... 127

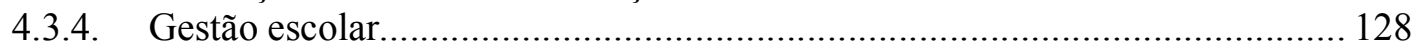

4.3.5. Formação e condições de trabalho dos docentes............................................ 129

4.3.6. Ambiente físico escolar (infraestrutura e recursos escolares) ......................... 130

4.4. Principais desafios para implementação de uma educação de melhor qualidade ... 132

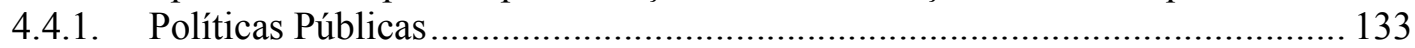

4.4.2. Planejamento e Gestão Escolar …………………….................................. 140

4.4.3. Coordenação e Prática Pedagógica............................................................ 147

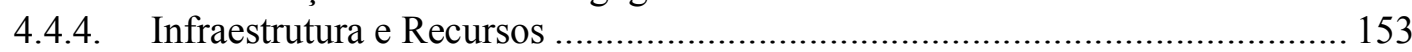

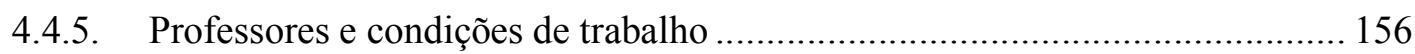

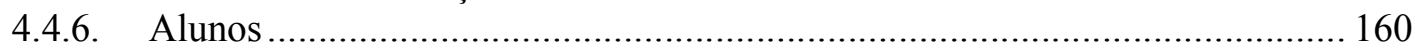

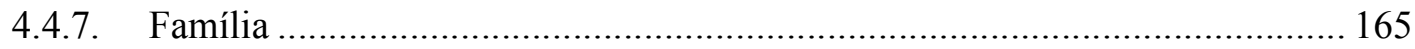

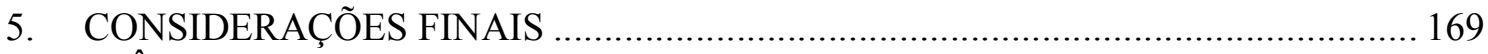

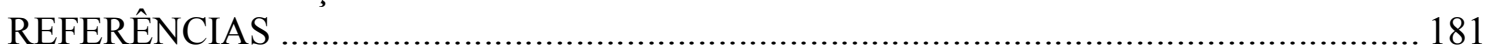

ANEXO 1 - Questionário aplicado aos alunos .............................................................. 187

ANEXO 2 - Questionário aplicado aos docentes............................................................ 188

ANEXO 3 - Questionário aplicado aos coordenadores pedagógicos ................................... 193

ANEXO 4 - Questionário aplicado aos diretores............................................................... 194 


\section{INTRODUÇÃO}

A formação de um ser humano integral requer do Estado, da sociedade e das escolas em particular, uma dinâmica que propicie ao indivíduo desenvolver competências aliadas à capacidade crítica para filtrar e compreender o mundo em que vive e, dessa forma, decidir e fazer escolhas autônomas e conscienciosas.

Do ponto de vista governamental, a educação é um vetor-chave para o desenvolvimento do País. Partindo-se da "tese comprovada teórica e empiricamente da relação positiva entre educação, crescimento econômico e diminuição das desigualdades sociais" (SETÚBAL, 2010, p. 349), o presente estudo concentra atenção nos principais desafios para a implementação de um Ensino Médio de qualidade na percepção de duas comunidades escolares, compreendidas, nesta pesquisa, como sendo a direção da escola, a coordenação pedagógica, os docentes e os alunos.

Segundo Langoni (1973), disparidades educacionais geram desigualdades de renda. Nesse mesmo sentido, Barros (2011, p. 37) afirma que a educação, em termos de quantidade de anos de estudo e de qualidade, em geral, é o fator de produção mais importante para gerar desigualdades regionais no Brasil. Essa constatação evidencia, de forma objetiva, a forma como o Estado pode e deve mitigar as desigualdades de renda e regionais no Brasil. E expõe a necessidade não apenas de se refletir sobre a qualidade da educação pública ofertada, mas principalmente de se definir meios para melhorá-la.

De acordo com Neri (2009), pesquisas demonstram que mais educação produz ganhos tanto em termos de eficiência econômica como de equidade distributiva. Porém, aponta para o paradoxo de baixo investimento em educação no Brasil, apesar da alta e persistente desigualdade social brasileira.

Para Setúbal, "uma sociedade mais justa e com equidade exige que todos os indivíduos sejam reconhecidos em sua dignidade pessoal e os diferentes grupos sociais aceitos e respeitados em suas diferenças materiais e simbólicas" (SETÚBAL, 2010, p. 358). Dessa forma, para o alcance desse objetivo requer-se uma educação formal abrangente e de qualidade.

Assim, de modo a se garantir o padrão de qualidade na educação determinado pela Constituição brasileira de 1988, quais são os principais desafios para a implementação de um Ensino Médio de qualidade na percepção de quem a executa?

$\mathrm{Na}$ literatura internacional encontram-se duas correntes dominantes no que se refere ao debate sobre qualidade em educação: uma econômica e outra humanista ou 
progressiva de educação (BARRETT et al, 2006, p. iii), voltada para a formação holística do indivíduo em sociedade.

Ambos os olhares enxergam a educação como propulsora do desenvolvimento humano e como fator decisivo para a diminuição das desigualdades sociais e consequente aumento do bem-estar individual e coletivo.

É nesse contexto que o presente estudo identifica as concepções que fundamentam a qualidade em educação na literatura nacional e internacional; apresenta o arcabouço legal brasileiro sobre educação de qualidade; descreve os contextos social e legal do Ensino Médio público brasileiro; investiga quais fatores, na percepção das comunidades escolares, propiciam ou dificultam a implementação de um Ensino Médio de qualidade. E, a partir disso, identifica e analisa os principais desafios enfrentados pelos "burocratas de nível de rua" (LIPSKY, 1980) de duas escolas públicas regulares do Distrito Federal, para a implementação de um Ensino Médio de melhor qualidade.

\subsection{Formulação do Problema de Pesquisa}

- Quais são os principais desafios para a implementação de um Ensino Médio de qualidade na percepção de duas comunidades escolares?

\subsection{Objetivos}

\subsubsection{Objetivo Geral}

- Analisar os principais desafios para a implementação de um Ensino Médio de qualidade.

\subsubsection{Objetivos Específicos}

- Identificar as concepções que fundamentam a qualidade em educação na literatura nacional e internacional;

- Descrever o arcabouço jurídico que norteia a qualidade da educação no Brasil;

- Caracterizar o contexto social e legal do Ensino Médio brasileiro;

- Investigar os principais fatores, na percepção de duas comunidades escolares, que influenciam na implementação de um Ensino Médio de qualidade no âmbito de duas escolas públicas regulares do Distrito Federal;

- Analisar os principais desafios para a implementação de um Ensino Médio de qualidade na percepção destas comunidades. 


\subsection{Justificativa}

Em uma sociedade do conhecimento, perante desafios transdisciplinares que afetam a vida no planeta Terra, faz-se premente uma educação equitativa, de qualidade, inclusiva, solidária, disseminadora de princípios e valores, tais como paz, solidariedade, respeito e alteridade. Uma formação educativa que instigue o estudante a se perceber e a perceber o outro, a se colocar no lugar do outro, a não só respeitar, mas enxergar a importância das diferenças, a compreender o local, o tempo histórico e a sociedade onde vive, uma educação que forme cidadãos para o mundo.

Assegurar educação inclusiva, equitativa e de qualidade, e promover oportunidades de aprendizagem ao longo da vida para todos é um dos Objetivos de Desenvolvimento Sustentável (ODS) a ser alcançado pelo Brasil e pelo mundo até 2030, conforme compromisso firmado em setembro de 2015 durante a Cúpula das Nações Unidas para o Desenvolvimento Sustentável (NAÇÕES UNIDAS, 2015).

Segundo o Conselho Nacional de Educação, a estrutura, os conteúdos, assim como as condições atuais do Ensino Médio no Brasil, "estão longe de atender às necessidades dos estudantes, tanto nos aspectos da formação para a cidadania como para o mundo do trabalho" (BRASIL, 2013, p. 145).

De acordo com a Pesquisa Nacional por Amostra de Domicílios (PNAD) 2014, realizada pelo Instituto Brasileiro de Geografia e Estatística (IBGE), a taxa de analfabetismo de pessoas de 15 anos ou mais de idade no Brasil, no ano de 2014, foi estimada em 8,3\%, o que corresponde a 13,2 milhões de pessoas. Além da quantidade de analfabetos plenos, o Brasil possui cerca de $20 \%$ dos indivíduos com 15 anos ou mais com menos de quatro anos de estudo, denominados analfabetos funcionais (IBGE, 2015, p. 43).

Em relação à população de 25 anos ou mais de idade, segundo dados da PNAD 2014, cerca de 60\% não havia cursado Ensino Médio completo até 2014 (IBGE, 2015, p. 44).

Isto posto, o alto índice de analfabetismo funcional aliado ao baixo percentual de concluintes no Ensino Médio revela uma perspectiva desafiadora para os governantes e gestores da área da educação brasileira.

No Brasil, percebe-se que há todo um esforço legal e em termos de política pública educacional para a implementação de Ensino Médio de qualidade, mas que na prática não se concretiza. Por que isso acontece? A presente pesquisa visou ouvir aqueles que estão diretamente envolvidos com a implementação da política educacional. Descobrir o que ocorre na ponta, quais são os principais desafios na percepção da comunidade escolar (considerados, 
nessa pesquisa: diretor (a), coordenadores pedagógicos, professores e estudantes) de duas escolas públicas regulares de relativo sucesso no Distrito Federal. Quais seriam os desafios? Gestão ineficaz, escassez de financiamento, prática pedagógica inadequada, falta de empatia dos alunos com os temas abordados (não correlação com a realidade vivida), baixa motivação de professores e alunos, falta de engajamento dos jovens que precisam dividir os estudos com o trabalho? O que fazer em termos de política pública?

Com o presente estudo visa-se contribuir com alguns subsídios para gestores públicos da área educacional, com vistas à melhoria do Ensino Médio no País.

Diante desse contexto, ouvir os atores que implementam a educação em duas escolas que obtiveram as melhores notas no Exame Nacional de Ensino Médio (ENEM) nos últimos anos, entre as escolas públicas regulares no Distrito Federal, pode trazer à luz elementos que contribuam para a implementação de uma educação de melhor qualidade. Além disso, atentar para o que os beneficiados da política, no caso os educandos, tem a nos dizer sobre o que faz diferença para um aprendizado mais satisfatório na escola, pode auxiliar no alinhamento de interesses e, consequentemente, no alcance de um resultado mais efetivo.

Nesse mesmo sentido, conforme recomendam Soares e Candian, estudos quantitativos de projetos de avaliação educacional "devem ser seguidos de estudos de caso, que descrevam na sua totalidade as escolas de sucesso, de forma que sua experiência possa ser utilizada por outras escolas" (SOARES, CANDIAN, 2007, p. 16).

A partir da investigação dos fatores que propiciam e/ou dificultam a implementação de um Ensino Médio de qualidade, objetiva-se analisar os principais desafios enfrentados pelas comunidades escolares para a implementação de um Ensino Médio público, regular, de excelência no Distrito Federal.

Dessa forma, este trabalho poderá contribuir com os formuladores e os diversos gestores da política pública educacional, analisando os principais gargalos e indicando possíveis caminhos para superação e melhoria da qualidade do ensino, apontados por aqueles que vivenciam os desafios na prática.

Outrossim, esta pesquisa buscou obter informações que pudessem contribuir para a implementação do Plano Nacional de Educação - PNE 2014-2024 (Lei 13.005/2014), com vistas ao alcance das metas, em especial da Meta 7: "fomentar a qualidade da Educação Básica”, de modo a aperfeiçoar as políticas públicas (planos, programas, projetos e ações) voltadas para a melhoria da qualidade do Ensino Médio no País. E, dessa forma, possibilitar uma atuação mais assertiva dos diversos gestores públicos engajados na melhoria da qualidade do Ensino Médio no Brasil (BRASIL, 2014). 


\section{REFERENCIAL TEÓRICO}

\subsection{Qualidade em Educação}

2.1.1. Concepções de qualidade em educação no Brasil e no Mundo

O termo qualidade em educação aparece em diversas normas e documentos governamentais brasileiros com diferentes sentidos ou definições. Um conceito polissêmico, segundo a literatura, que varia conforme o referencial de análise.

Do ponto de vista jurídico, a qualidade educacional perpassa o direito fundamental, os direitos humanos e, por conseguinte, os conceitos de cidadania, dignidade da pessoa humana e formação para o trabalho, conforme estabelece a Carta Magna brasileira.

Sob a ótica econômica, a qualidade do ensino é compreendida em termos de formação de capital humano para o trabalho. Conforme nos ensina Barros, capital humano é composto por três elementos básicos: formação educacional do indivíduo, experiências prévias de trabalho e capacidade física de trabalho. De acordo com o estudo realizado pelo autor, as desigualdades econômicas regionais no Brasil se devem, em grande parte, pelas desigualdades de capital humano e, mais especificamente, pela desigualdade educacional tanto em termos de qualidade da educação recebida como de quantidade de anos de estudo realizado (BARROS, 2011).

Sob o olhar social, a qualidade educacional abrange, entre outros aspectos, os conceitos de emancipação do sujeito, participação social crítica, capacidade de optar e de decidir, asseverada por Paulo Freire (1989). Para Gadotti, "falar em qualidade social da educação é falar de uma nova qualidade, onde se acentua o aspecto social, cultural e ambiental da educação, em que se valoriza não só o conhecimento simbólico, mas também o sensivel e o técnico” (GADOTTI, 2010, p. 1, grifos do autor).

Segundo Dourado, Oliveira e Santos (2007), para se verificar a qualidade da educação é preciso considerar não apenas a dimensão intra, mas também as dimensões extraescolares que afetam as condições de ensino e aprendizagem nas escolas. Visão compartilhada por Soares e Xavier, quando recomendam que o Índice de Desenvolvimento da Educação Básica (IDEB) “deve ser divulgado de forma contextualizada”, contendo, no mínimo, "uma descrição do nível socioeconômico das escolas ou dos municípios", sendo desejável, que outras características, tais como infraestrutura escolar, sejam disponibilizadas também (SOARES, XAVIER, 2013, p. 920). Nesse mesmo sentido, Gadotti entende que "há 
um conjunto de variáveis, intra e extraescolares, que interferem na qualidade da educação" (GADOTTI, 2010, p. 1), por isso, deve ser analisada de forma sistêmica.

Com o objetivo de alcançar uma educação emancipadora que contemple todas as dimensões da formação humana, as Diretrizes Curriculares Nacionais da Educação Básica, publicada em 2013, conceitua qualidade da educação "como uma construção histórica que assume diferentes significados em tempos e espaços diversos e tem relação com os lugares de onde falam os sujeitos, os grupos sociais a que pertencem, os interesses e os valores envolvidos, os projetos de sociedade em jogo" (BRASIL, 2013, p. 151).

Segundo a Organização das Nações Unidas para a Educação, a Ciência e a Cultura (Unesco), uma educação básica de qualidade é essencial para: a erradicação da pobreza; a redução da mortalidade infantil; o controle do crescimento populacional; o alcance da igualdade de gênero e para se assegurar o desenvolvimento sustentável, a paz e a democracia (UNESCO, 2014). De acordo com o Relatório Delors, a educação para o século 21 requer capacitar o indivíduo em quatro pilares fundamentais: aprender a ser, aprender a conviver, aprender a conhecer e aprender a fazer (DELORS, 1996).

Nesse sentido, está o desenvolvimento de competências não só cognitivas, mas também socioemocionais, alvo do Fórum Internacional de Políticas Públicas: Educar para as competências do século 21, promovido em conjunto pelo Ministério da Educação (MEC), pelo Instituto Nacional de Estudos e Pesquisas Educacionais Anísio Teixeira (INEP), pelo Instituto Ayrton Senna e pela Organização para a Cooperação e Desenvolvimento Econômico (OCDE), em 2014. Previstas na Medida Provisória nº746/2016 (BRASIL, 2016b), conhecida por Reforma do Ensino Médio, as competências socioemocionais incluem aspectos relacionados à motivação, perseverança, responsabilidade, colaboração, comunicação, extroversão, amabilidade, criatividade, estabilidade emocional, pensamento crítico, resiliência perante dificuldades, abertura a experiências, entre outros fatores (ABED, 2014; FÓRUM INTERNACIONAL, 2014).

A partir de estudos realizados, Paul Tough destaca a importância de se estimular as competências socioemocionais e a "mentalidade de crescimento" (growth mindset) nos jovens, associada com a crença de que o indivíduo pode mudar e melhorar suas habilidades através do esforço (in FÓRUM INTERNACIONAL, 2014, p. 3).

Segundo o documento do Fórum, o professor James Heckman afirma que tais competências são "determinantes para o êxito na vida [...] e podem ser estimuladas por meio de intervenções e formulação de políticas públicas”. Assim como salienta que as famílias são 
fundamentais no desenvolvimento dessas habilidades (in FÓRUM INTERNACIONAL, 2014, p. 3).

Para Koïchiro Matsuura, diretor geral da Unesco entre 1999 e 2009, a educação primária e secundária devem garantir que todos os alunos adquiram conhecimentos, habilidades e valores necessários para melhorar suas vidas e desempenhar seu papel na construção de sociedades mais pacíficas e equitativas, isto é, para o exercício da cidadania responsável. Segundo ele, a qualidade em educação, adaptável à luz do contexto de cada sociedade, perpassa, na maioria dos países, dois objetivos principais:

O primeiro é garantir o desenvolvimento cognitivo dos aprendizes; o segundo enfatiza a papel da educação no provimento do desenvolvimento criativo e emocional dos aprendizes, ajudando-os a adquirir valores e atitudes para uma cidadania responsável. Por fim, a qualidade deve ser aprovada no teste de equidade: um sistema educacional caracterizado pela discriminação contra qualquer grupo particular não está cumprindo sua missão (UNESCO, 2005, p. 5).

De acordo com relatório da Unesco, inúmeras necessidades são apontadas para melhorar a qualidade da aprendizagem: professores com melhor capacitação, livros didáticos de melhor qualidade disponíveis para todos os alunos, renovação pedagógica, e ambientes de aprendizagem mais agradáveis. Estabelece, ainda, como determinantes principais para melhoria da qualidade em educação o relacionamento entre alunos e professores, pela qual há evidências de que a aprendizagem seja mais fluente quando há uma correspondência estreita de valores e objetivos entre os dois grupos, assim como os recursos disponíveis para as escolas para o alcance dos objetivos curriculares e para as práticas de ensino adotadas (UNESCO, 2005, p. 228).

Para Irina Bokova, diretora geral da Unesco entre 2009 e 2017, a qualidade de um sistema educacional é reflexo da qualidade de seus educadores, por isso, "desenvolver o seu potencial é fundamental para elevar a qualidade da aprendizagem. Dados mostram que a qualidade da educação melhora quando os professores são apoiados - e pioram quando eles não o são" (UNESCO, 2014, p. 3). Com vistas ao desenvolvimento de competências socioemocionais, além do apoio necessário aos professores é preciso incorporar o ensino dessas competências em sua formação (FÓRUM INTERNACIONAL, 2014, p. 3).

No cenário internacional, a problematização do entendimento sobre educação de qualidade perpassa pela dificuldade de se chegar a um consenso sobre o aspecto conceitual do termo qualidade. Uma ampla literatura internacional citada no estudo de Barrett et al (2006, p.13 a 15, a saber: BANCO MUNDIAL, 1990; CHAPMAN et al, 1996; CHITTY, 2002; DELAMONICA et al, 2004; HAWES, STEPHENS, 1990; HEYNEMAN, WHITE, 1986; 
LAWRENCE, TATE, 1997; LOCKHEED, HANUSHEK, 1988; MICHAELOWA, 2001; PSACHAROPOULOS, WOODHALL, 1985; SAYED, 1997; TIBI, 1985; UNESCO 2000; WATKINS, 2000; WELCH, 2000; WINDHAM, 1988) sinaliza a existência de cinco dimensões recorrentes no debate, a saber: efetividade (atingir os objetivos almejados); eficiência (fazer o melhor uso dos recursos, monetários ou não, para alcançar os objetivos educacionais); equidade (qualidade educacional como um direito humano para todos); relevância (educação para quê?) e sustentabilidade (obrigação de estabelecer e manter a mesmas oportunidades para todos os indivíduos, ao longo do tempo, para que alcancem resultados de valor).

Todavia, a vastidão de temas e as distintas priorizações de governos, organismos internacionais e acadêmicos, no tocante à área, demonstram a fragilidade na busca por uma definição de educação de qualidade universalmente aceita.

Em contrapartida, o que o levantamento conceitual realizado por instituições e pesquisadores internacionais parece revelar é que as definições e o estabelecimento de prioridades no campo da qualidade educacional estão vinculados a fatores como o nível de desenvolvimento das nações e o escopo de abrangência no entendimento do que venha a ser a formação de um ser humano e a priorização de sua bagagem sociocultural para interagir em sociedade.

Quanto à relação prioridades na qualidade da educação versus estágios de desenvolvimento dos países, Barrett et al (2006) sintetizaram o quadro relacional apresentado a seguir (Quadro 1), o qual demonstra que a ênfase no debate sobre qualidade em educação varia conforme o tipo de interlocutor.

Quadro 1: Ênfases no debate sobre qualidade educacional conforme estágios de desenvolvimento dos países

\begin{tabular}{|l|l|}
\hline Estado & Ênfase no debate sobre qualidade \\
\hline $\begin{array}{l}\text { Pós-conflito; Estados recém- } \\
\text { fundados }\end{array}$ & $\begin{array}{l}\text { Subsistência, segurança, confiabilidade do sistema escolar, } \\
\text { currículo. }\end{array}$ \\
\hline Países de baixa renda & $\begin{array}{l}\text { Acesso, meios de subsistência (enfrentamento, } \\
\text { durabilidade, adaptabilidade) - ensino fundamental. }\end{array}$ \\
\hline Países de renda média & Continuidade - Ensino Médio, grupos desfavorecidos. \\
\hline Países da OCDE & $\begin{array}{l}\text { Competências, responsabilidade, aprendizagem ao longo } \\
\text { da vida. }\end{array}$ \\
\hline
\end{tabular}

Fonte: Sintetizado de: McDowell (2002); Michaelowa (2001); Akkari (2005); Romano (2002); Kagia (2005), apud Barrett et al (2006, p. 14) (traduzido do original em inglês). 
Acrescenta-se que, quando a discussão sobre educação de qualidade engloba o aspecto do contexto de desigualdade entre sociedades e a busca por políticas públicas corretivas, a busca conceitual do termo qualidade deixa de ser uma seara puramente técnica, passando a envolver conflitos de interesses nacionais e globais. Nesse sentido, como ressaltam Robertson et al (2007 apud TIKLY, 2010, p. 6), discursos políticos antagônicos sobre o entendimento por qualidade em educação são lançados em múltiplas escalas, do global ao local, e envolvem a negociação de interesses conflitantes.

$\mathrm{Na}$ seara da discussão conceitual, a literatura internacional tem encontrado dois campos ou tradições dominantes no que se refere ao debate sobre qualidade: uma visão econômica de educação e uma visão humanista ou progressiva de educação (BARRETT et al, 2006, p. iii). A primeira vertente utiliza, como elementos de avaliação de qualidade, resultados mensuráveis quantitativos. A segunda volta-se para a discussão de processos educacionais.

Ao passo que a visão econômica prioriza aspectos como taxas de retorno sobre investimento em educação (relacionadas, por exemplo, à percepção salarial e ao desempenho cognitivo verificado em avaliações externas), assim como taxas de escolarização, retenção e fluxo, a visão humanista tende a relativizar a ideia de indicadores educacionais (ainda que valorize a aquisição de conhecimentos e habilidades) e a relacionar qualidade ao ambiente que é formado na escola e em sala de aula, onde se constrói atitudes e valores culturais.

Constatou-se que a abordagem humanista, cuja principal influência advém dos autores Pestalozzi, Froebel e Dewey (BARRETT et al, 2006, p. 4), comporta três metas educacionais: a realização humana, a preparação para o mundo do trabalho e a contribuição para o progresso e a mudança social.

Deve-se ressaltar que há uma ligação entre as duas distintas tradições dominantes e a reflexão de organismos internacionais sobre o conceito de educação de qualidade. Como exemplo, ao passo que o Banco Mundial adota um pensamento com viés econômico sobre educação, a Unesco adota uma visão humanista, para além da economia.

Elaborada no âmbito da Unesco, para subsidiar o Relatório de Monitoramento Global do programa Educação Para Todos, apresenta-se, na Figura 1 a seguir, um modelo de estrutura para entendimento do que compõe uma educação de qualidade. 
Figura 1: Um referencial para entender qualidade da educação do ponto de vista da Unesco.

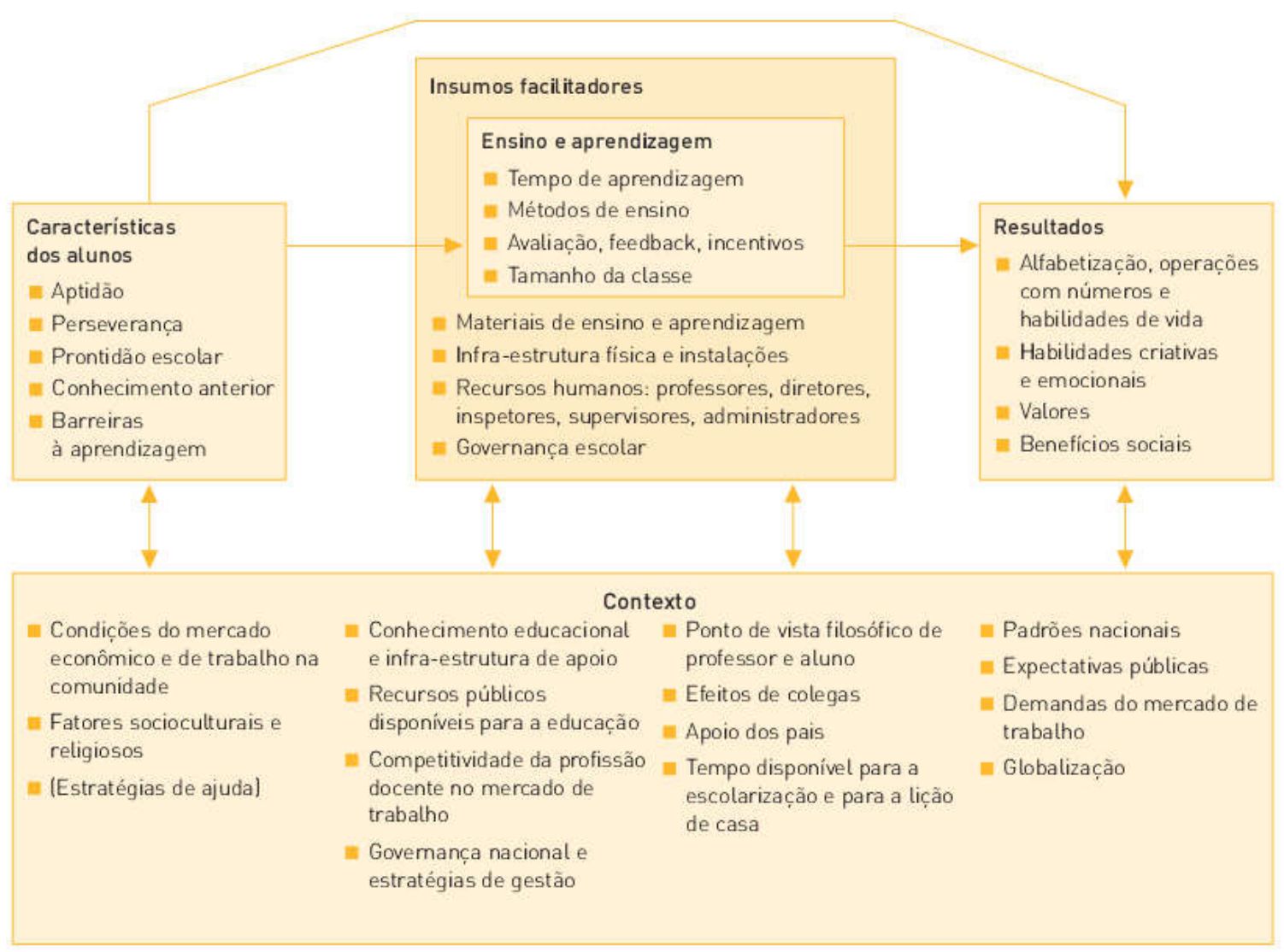

Fonte: UNESCO, 2005, p. 36.

Com base nos inúmeros debates nacionais sobre educação de qualidade, o consórcio de pesquisa sobre a implementação da qualidade da educação em países de baixa renda, liderado pela Universidade de Bristol no Reino Unido em cooperação com nações africanas, Paquistão e Chile, denominado EdQual, estabeleceu uma estrutura de insumos e processos que orientariam a promoção de uma educação de qualidade na África, a qual foi sintetizada por Tikly (2010) na Figura 2. 
Figura 2: Estrutura para a compreensão da qualidade da educação em África.

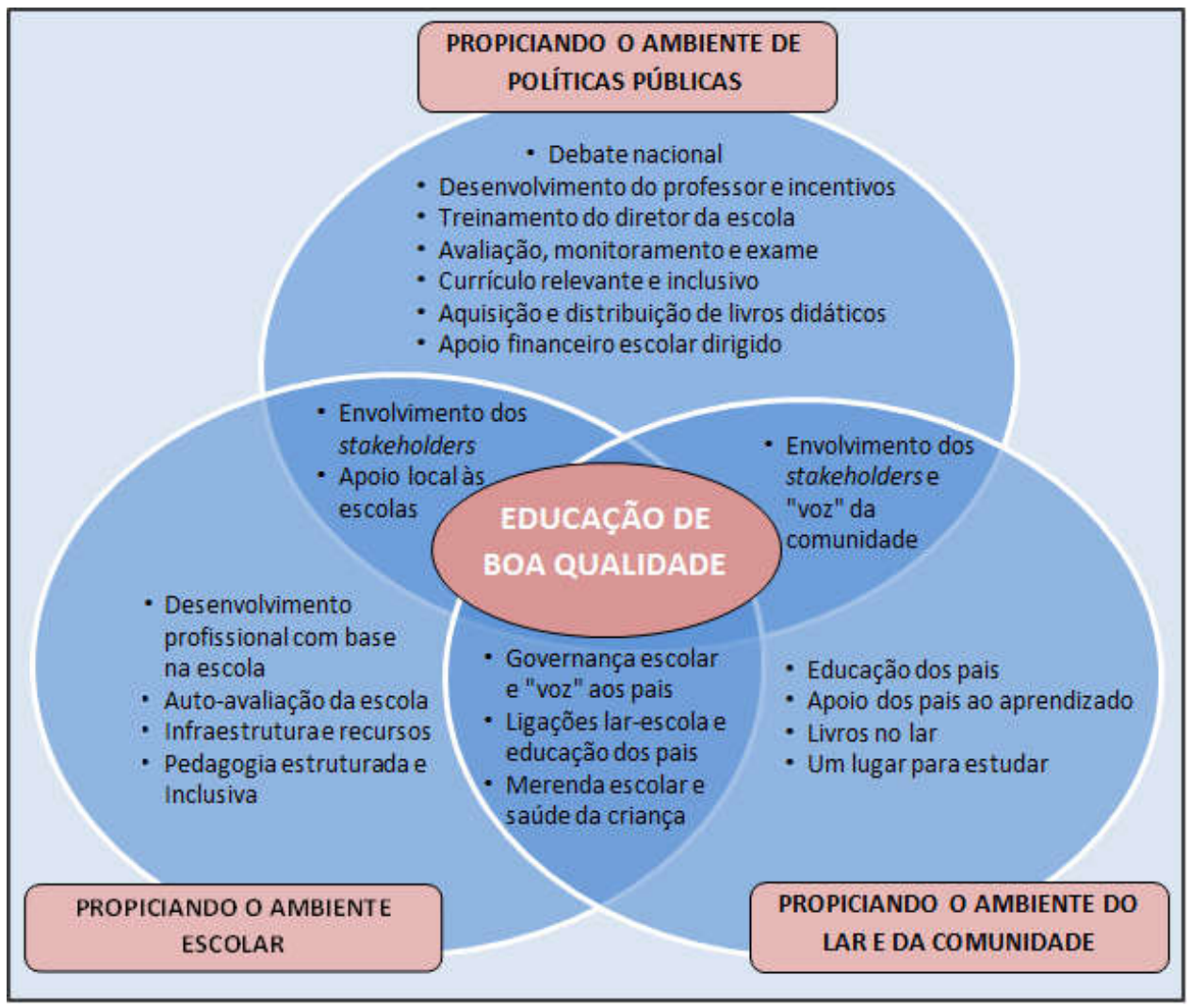

Fonte: TIKLY, 2010, p. 19 (traduzido do original em inglês).

Segundo Fonseca, no Brasil, em específico, a qualidade educacional oscilou entre as duas correntes dominantes durante as últimas décadas. Enquanto leis e programas se aproximavam de uma interpretação mais humanista:

ressaltando a igualdade de oportunidades para todos, a gestão democrática do sistema e o compromisso ético com a educação [...] Na prática, a ação educativa deu ênfase a programas e projetos orientados pela lógica do campo econômico, dirigindo a ação escolar para as atividades instrumentais do fazer pedagógico e para a administração de meios ou insumos. A qualidade, por sua vez, foi sendo legitimada pelo horizonte restrito da competitividade, cuja medida é a boa colocação no ranking das avaliações externas (FONSECA, 2009, p. 172 e 173).

Esse enfoque utilitarista, segundo a autora "não é suficiente para orientar a qualidade da ação educativa", a qual tem como perspectiva "as diferentes dimensões da vida social" (FONSECA, 2009, p. 173).

Um processo em construção, esse posicionamento entre as duas correntes pode ser visto na postura política do País em suas participações em organismos internacionais, como Unesco e Banco Mundial, bem como nas relações bilaterais e multilaterais, a exemplo das declarações dos Ministros de Educação do BRICS, grupo político de cooperação internacional 
composto pelo Brasil, Rússia, Índia, China e África do Sul, com orientações voltadas tanto à formação para o mercado de trabalho e qualificação profissional quanto para a melhoria em equidade, inclusão e qualidade dos nossos sistemas educacionais (BRICS, 2015).

No âmbito nacional, o mesmo se percebe na formulação de políticas públicas, programas e estudos voltados à busca pela efetivação da qualidade na educação, a exemplos: da elaboração de leis, tais como a Lei 13.005/2014 (BRASIL, 2014), que instituiu o PNE 2014-2024; do embasamento conceitual de diversos programas educacionais do MEC e da busca por modelos de mensuração de elementos estruturais que orientariam o governo em suas decisões no investimento em educação de qualidade, a exemplo do CAQi (Custo Aluno Qualidade Inicial), previsto no atual PNE.

Cabe salientar que a perspectiva da competitividade tem sido objeto de crítica de inúmeros estudiosos dos processos educacionais, que observam a importância de se transcender a lógica do ranqueamento em prol de uma perspectiva capaz de considerar a efetividade transformadora do processo educacional.

Porém, conforme salientam Soares e Xavier, "o uso dos resultados de rendimento e aprendizado no monitoramento de sistemas de educação básica” é a forma que o Estado tem para saber "se o direito à educação de seus cidadãos está sendo atendido. Na ausência de um sistema como esse, o direito público subjetivo estabelecido no texto constitucional não pode ser monitorado e, eventualmente, exigido" (SOARES, XAVIER, 2013, p. 905).

Ademais, de acordo com Bryk e Hermanson, um conjunto de indicadores é uma forma de descrever o sistema e não uma ferramenta de gestão escolar: "para isso, é preciso considerar cada processo da escola - administrativo, interação com a sociedade e de ensino/aprendizagem - e escolher as informações de estrutura e resultado adequadas para o monitoramento de cada processo" (BRYK, HERMANSON, 1993, apud SOARES, XAVIER, 2013, p. 920).

Por esse motivo, conforme nos ensinam Soares e Xavier, o Índice de Desenvolvimento da Educação Básica (IDEB), um indicador que mede a qualidade do ensino no Brasil, "deve ser divulgado de forma contextualizada", contendo, no mínimo, "uma descrição do nível socioeconômico das escolas ou dos municípios”, sendo desejável, também, que outras características, tais como infraestrutura escolar, sejam disponibilizadas. Para os autores, “isso não advoga que as expectativas relativas ao aprendizado dos alunos devem ser diferentes em diferentes municípios, mas apenas que, para atingir os aprendizados necessários, alguns cenários sociais são mais adversos do que outros" (SOARES, XAVIER, 2013, p. 920). 
Para o educador Paulo Freire (1989), reconhecido mundialmente, é preciso construir uma nova qualidade que consiga acolher a todos e a todas, que ascenda o sujeito da ingenuidade à criticidade. Segundo o educador alfabetizar-se não é aprender a repetir palavras, mas a dizer a sua palavra, criadora de cultura. Acrescenta, ainda, que a palavra viva se plenifica no trabalho. Assim, educação, trabalho e cidadania não estão dissociados (FREIRE, 2006).

Dessa forma, não há que se falar em antagonismo entre a visão social e a econômica, pelo contrário, há que se conjugar concepções, esforços, metodologias e instrumentos - e as avaliações são parte importante desses instrumentos - em busca de uma melhor qualidade educativa.

De acordo com as Diretrizes Curriculares Nacionais, a função precípua da educação e, mais especificamente do Ensino Médio, "vai além da formação profissional, e atinge a construção da cidadania”. Segundo o documento, é preciso oferecer aos jovens:

\begin{abstract}
novas perspectivas culturais para que possam expandir seus horizontes e dotá-los de autonomia intelectual, assegurando-lhes o acesso ao conhecimento historicamente acumulado e à produção coletiva de novos conhecimentos, sem perder de vista que a educação também é, em grande medida, uma chave para o exercício dos demais direitos sociais (BRASIL, 2013, p. 145).
\end{abstract}

No entanto, uma educação pública de qualidade, para diminuir as desigualdades e para promover o desenvolvimento nacional, precisa, necessariamente, estar atrelada à igualdade de oportunidade e de acesso ao ensino em todo o País.

Com o intuito de corroborar para a melhoria da qualidade da educação pública brasileira, com equidade, o movimento social denominado Campanha Nacional pelo Direito à Educação, articulado com organizações da sociedade civil, instituições acadêmicas e de pesquisa, institutos de pesquisa, pais/mães e alunos/alunas e apoiado por organismos internacionais, como a Unesco e a União Europeia, promoveu amplo debate entre os anos de 2002 e 2005 com o objetivo principal de definir os critérios mínimos para a promoção de uma educação pública de qualidade no Brasil. Para isso, utilizou-se o conceito de qualidade sob a perspectiva democrática e de qualidade social, em permanente construção. Após a maturação de consensos por meio de encontros e oficinas, formulou-se o índice Custo Aluno Qualidade Inicial - CAQi no ano de 2005 (CARREIRA, PINTO, 2011).

Construído com base em ampla participação social, por meio de encontros, debates, seminários e diálogo com outros movimentos sociais e instituições acadêmicas e de pesquisa, o CAQi considerou como conceito de educação de qualidade aquela que (CARREIRA, PINTO, 2011, p. 18): 
- Fortaleça as pessoas para viver a vida em sua "inteireza", para aprender umas com as outras, atuar pelos seus direitos, cumprir seus deveres, ter melhor qualidade de vida e lutar por uma sociedade mais justa e solidária. Uma educação que reconheça e dialogue com as necessidades do mercado do trabalho, mas que vá além delas;

- Valorize a diversidade humana, superando preconceitos e discriminações;

- Permita a redescoberta do nosso vínculo com a natureza e nos estimula a cuidar do planeta, questionando o consumismo e as ações gananciosas e predatórias da ação humana; que mude comportamentos no cotidiano e estimule as pessoas a pressionarem as autoridades a promover políticas públicas com vistas à sustentabilidade ambiental;

- Faz aprender e construir a democracia no dia a dia das casas, da escola, do trabalho, da praça, dos meios de comunicação, dos governos e em todos os lugares, de forma não violenta e repudiando posturas e ações autoritárias;

- Reconhece as desigualdades sociais presentes na própria educação, como as de renda, raça e etnia, gênero, região, de orientação sexual, de deficiência física e mental. E reconhece que o enfrentamento dessas desigualdades exige mudanças que vão além da educação, exigem ações articuladas entre políticas sociais e econômicas;

- Considera as especificidades, as necessidades, as potencialidades e os desafios de uma localidade, de uma região, de um país.

- Aprimora-se por meio da participação social e política. Qualidade real é aquela que exige participação e controle social. Portanto, precisa estar ligada a uma instituição ou organização (como comitês e conselhos) e a processos participativos e democráticos que sejam independentes da vontade política do gestor ou da gestora em exercício. Participação e transparência nas informações são direitos do cidadão;

- Envolve políticas consistentes de avaliação, que não podem se limitar à medição do desempenho dos alunos em testes padronizados, mas que devem considerar a opinião dos trabalhadores e dos usuários da educação, incorporando instrumentos de avaliação interna e externa das instituições escolares;

- Exige investimentos financeiros de longo prazo, com aprimoramento das formas de gestão democrática e controle social para o melhor uso desses recursos.

Dessa forma, a partir de uma visão humanista da educação, sem prescindir do olhar voltado para o mercado de trabalho, a "matriz" do Custo Aluno-Qualidade Inicial desenvolvida pela Campanha Nacional pelo Direito à Educação, compreende os seguintes aspectos na construção de uma educação de qualidade: os desafios referentes às desigualdades 
na educação; as dimensões fundamentais dos processos de ensino e aprendizagem; os insumos, recursos humanos e materiais necessários.

Segundo Carreira e Pinto (2011, p. 22), no tocante ao processo de ensino e aprendizagem, o CAQi prevê quatro dimensões fundamentais, a saber:

- Dimensão do conhecimento: discute a relevância dos conteúdos curriculares, sua relação com os processos produtivos e as relações entre teoria e prática na compreensão do conhecimento científico.

- Dimensão estética: compreende as condições do ambiente educativo que possibilitam prazer, criatividade e pertencimento, assim como à formação dos educadores para potencializar a capacidade criativa e apreciativa dos aprendizes.

- Dimensão ambiental: envolve as condições necessárias para que estudantes, educadores e comunidade escolar possam sentir a escola como um espaço que promova relações de respeito por si e pelos outros e de pertencimento à natureza.

- Dimensão dos relacionamentos humanos: trata da promoção de vínculos, de interação e de reconhecimento e respeito à diversidade humana.

Com vistas a se alcançar um padrão mínimo, básico, previsto na legislação educacional brasileira, o valor do CAQi foi calculado a partir dos insumos indispensáveis ao desenvolvimento dos processos de ensino e aprendizagem. Entre os insumos, a formulação do CAQi previu quatro grandes tipos (CARREIRA, PINTO, 2011, p. 23 a 28):

1. Estrutura e funcionamento: o valor varia de acordo com a etapa e a modalidade de ensino;

2. Trabalhadores e trabalhadoras em educação: prevê salário digno e perspectiva de carreira aos profissionais do magistério e aos demais profissionais da educação, assim como formação docente prevista no Plano Nacional de Educação de 2001;

3. Gestão democrática;

4. Acesso e à permanência na escola.

Entre os principais fatores que geram impactos no cálculo do valor do CAQi e que estão diretamente ligados à melhoria da qualidade da educação estão (CARREIRA, PINTO, 2011, p. 32 e 33):

1. Tamanho da creche ou da escola;

2. Jornada dos alunos e das crianças;

3. Número de alunos (as) ou crianças por turma; 
4. Salários dos profissionais da educação: insumo de maior impacto sobre o CAQi, (representa cerca de $80 \%$ do valor do índice).

Corroborando nesse sentido, Barbosa afirma que "a melhoria da educação pública passa pelo aumento dos recursos a ela destinados e os salários dos professores compõem grande parte desse montante" (BARBOSA, 2014, p. 528).

Estudo realizado por Rivkin, Hanushek e Kain (2005) constatou a importância da eficácia do professor na determinação da qualidade da educação escolar.

Segundo relatório da Unesco, em países em desenvolvimento, "a maioria dos estudos que encontram relações significativas sugere que o desempenho cognitivo, medido por testes padronizados, aumenta à medida que aumentam os gastos escolares, a educação de professores e as facilidades escolares" (UNESCO, 2005, p. 228). Os estudos indicam que:

Os níveis de desempenho cognitivo são significativamente melhorados pela provisão de livros didáticos e outros materiais pedagógicos (Quênia, Filipinas), por redução no tamanho das turmas (Índia, Israel, África do Sul) e pela oferta de recuperação escolar acolhedora por para professores recrutados localmente (Índia) (UNESCO, 2005, p. 229).

Esses estudos demonstram, ainda, que recursos são extremamente importantes para a qualidade da educação, particularmente em lugares mais pobres. Porém, destacam que:

As escolas definitivamente não são fábricas que produzem resultados de acordo com uma receita, de uma maneira tecnicamente determinística. O que é crucial para sua eficácia é o próprio processo educacional, no qual professores e alunos utilizam os recursos disponíveis e interagem reciprocamente de maneiras criativas (UNESCO, 2005, p. 229).

Em relação ao tema, pesquisas revelam, ainda, um ponto de convergência nas experiências nacionais de sucesso, qual seja: valorização do magistério, com capacitação, apoio, padrões de recrutamento e de remuneração destacadas das outras profisssões. Ademais, grande ênfase é dada à atuação do governo como condutor-chave desse processo. Nessa direção, percebeu-se a existência de políticas de longo prazo que perdurem à gestão de governos. Evidenciou-se que uma visão sólida e duradoura sobre o modelo de educação que se almeja, aliada à constância do fator qualidade, são aspectos indispensáveis para a melhoria da educação ofertada (UNESCO, 2005, p. 21).

No entanto, é preciso salientar que, conforme nos aponta Tavares (2014, p. 35), na literatura econômica há duas vertentes sobre o tema. Há trabalhos que não encontram "uma relação positiva sistemática entre os níveis salariais e medidas de proficiência ou outros resultados educacionais, como aprovação ou conclusão" (PODGURSKY, 2011, apud 
TAVARES, 2014, p. 34) e autores que afirmam que políticas de aumento salarial dos professores "têm o potencial de afetar o esforço do professor e, portanto, o aprendizado. No entanto, para isto elas deveriam vir acompanhadas de políticas complementares, como a maior autonomia aos gestores escolares, que os permitissem, por exemplo, contratar e demitir professores" (HANUSHEK, 2003; MILANOWSKI, 2008, apud TAVARES, 2014, p. 35).

Um caminho do meio pode ser a conclusão alcançada por Nascimento em artigo sobre "Recursos destinados à educação e Desempenho Escolar: uma revisão na literatura internacional", no qual pondera que:

\begin{abstract}
A realidade de cada escola e de seus alunos indicará a pertinência ou não de se investir mais em recursos educacionais (como defendem Hedges, Laine e Greenwald), sendo sempre adequada a discussão em torno da eficiência e eficácia dos gastos da escola (ponto central de Hanushek) (NASCIMENTO, 2007, p. 132 e $133)$.
\end{abstract}

Visão compartilhada por Gusso e Oliveira, que recomendam que o "foco na eficiência do gasto seja maior do que se alvejar o aumento dos mesmos" (GUSSO, OLIVEIRA, 2014, p. 212). E Tikly, que aponta que o apoio financeiro escolar deve ser dirigido (TIKLY, 2010).

No Brasil, segundo Frigotto, "os atuais investimentos em educação pública passam longe das necessidades para dar uma base material ao ensino público de qualidade" (FRIGOTTO, 2013, p. 12). Para Amaral (2012), há uma relação clara, porém, não linear, entre os valores financeiros aplicados em educação e a sua qualidade, o que corrobora com o ponto de vista de Hanushek.

Nesse contexto, a definição de um referencial sobre a qualidade que se pretende, nos diversos níveis e modalidades educacionais, é essencial para o planejamento público brasileiro na área educacional. Diante disso, a definição do CAQi, previsto no PNE e proposto pela Campanha Nacional pelo Direito à Educação, poderá contribuir nessa reflexão.

É importante destacar ainda, que para o enfrentamento das desigualdades existentes na educação brasileira (de renda, regionais, raciais, entre sexos, decorrentes de deficiência ou de orientação sexual), a Campanha Nacional pelo Direito à Educação propõe, também, CAQis específicos e CAQis adicionais, destinados a aumentar o valor do CAQi em territórios e/ou regiões desfavorecidas ou junto a grupos discriminados.

Para além da questão financeira, cabe salientar ainda que, de acordo com Setúbal (2010, p. 359), para não se aumentar as desigualdades entre as escolas e nem deixar para trás uma parcela significativa de alunos, a busca por qualidade em educação para todos no País deve levar em conta, ainda, os seguintes fatores: 
1. Articulação entre a educação, as políticas sociais e os equipamentos públicos nos territórios;

2. Currículos e metodologias mais adequados ao mundo contemporâneo e à realidade escolar;

3. Apoio pedagógico e acompanhamento próximo dos alunos com maiores dificuldades;

4. O professor no centro da educação de qualidade.

Assim, é importante ressaltar que a busca por qualidade em educação deve ser equitativa, garantindo a formação de todos e todas no País.

Cabe salientar ainda, que as concepções aqui apresentadas não indicam, por si só, estratégias concretas de efetivação da educação de qualidade, porém, possibilitam os gestores da área a pensar a política educacional de forma mais abrangente e contextualizada.

Construído esse panorama, o presente estudo passa a descrever o contexto legal e social do Ensino Médio público brasileiro e a contextualizar o desafio da implementação de políticas públicas, conforme a literatura científica. E, na sequência, mergulha em duas realidades escolares para investigar os desafios postos para a concretização de uma educação de melhor qualidade na prática.

\subsubsection{Qualidade da educação na legislação brasileira}

A Carta Magna brasileira preconiza a educação como direito social de todos e dever do Estado e da família, a qual será promovida e incentivada com a colaboração da sociedade, visando o pleno desenvolvimento da pessoa, seu preparo para o exercício da cidadania e sua qualificação para o trabalho. Estabelece, ainda, como princípio basilar do ensino, a garantia de padrão de qualidade (BRASIL, 2016a, arts. 6, 205 e 206, inciso VII).

Para o alcance desse objetivo, a Constituição determina, no artigo 214, a criação de um Plano Nacional de Educação (PNE), de duração decenal, com o qual se visa articular o sistema nacional de educação, em regime de colaboração, e definir diretrizes, objetivos, metas e estratégias de implementação que conduzam, entre outros aspectos, à erradicação do analfabetismo no país, à universalização do atendimento escolar e à melhoria da qualidade do ensino.

De acordo com a Lei de Diretrizes e Bases da Educação Nacional (LDB), Lei n9394/1996, os padrões mínimos de qualidade de ensino são definidos como a variedade e a 
quantidade mínimas, por aluno, de insumos indispensáveis ao desenvolvimento do processo de ensino-aprendizagem (BRASIL, 1996b).

Também no ano de 1996, a Emenda Constitucional $n^{\circ} 14$ alterou o $§ 1^{\circ}$ do artigo 211 da Constituição Federal, estabelecendo que a União "exercerá, em matéria educacional, função redistributiva e supletiva, de forma a garantir equalização de oportunidades educacionais e padrão mínimo de qualidade do ensino mediante assistência técnica e financeira aos Estados, ao Distrito Federal e aos Municípios” (BRASIL, 1996a, grifo nosso).

Com o objetivo de se viabilizar essa cooperação, ainda no ano de 1996, foi criado e regulamentado o Fundo de Manutenção e Desenvolvimento do Ensino Fundamental e de Valorização do Magistério - FUNDEF, o qual teve como foco central a equidade, buscando-se o estabelecimento de um custo mínimo por aluno, por ano, definido nacionalmente.

Em 2001 foi promulgado o primeiro PNE (BRASIL, 2001), o qual apresentou como um de seus objetivos "a melhoria da qualidade do ensino em todos os níveis". Nesse sentido, estabeleceu como desafio a adequação da aprendizagem dos alunos a um padrão mínimo de qualidade (capítulo V, item 11.3.1, 24, PNE 2001 e art. 211,§ $1^{\circ}$, CF e art. $60, \S 4^{\circ}$, ADCT), para isso, propõe a busca pelo custo-aluno-qualidade.

Para enfrentar o desafio de uma educação de qualidade para todos os brasileiros, o Ministério da Educação lançou, em 2007, o Plano de Desenvolvimento da Educação (PDE), por meio do Decreto n6.094, de 24 de abril de 2007 (BRASIL, 2007).

Com vistas a aferir a qualidade da Educação Básica no Brasil, o Instituto Nacional de Estudos e Pesquisas Educacionais Anísio Teixeira (INEP), autarquia federal vinculada ao Ministério da Educação (MEC), criou o Índice de Desenvolvimento da Educação Básica (IDEB) no ano de 2007.

Esse índice reúne, em um só indicador, dois conceitos igualmente importantes para a aferição da qualidade da educação: taxa de rendimento escolar (aprovação), obtida a partir do Censo Escolar; e desempenho obtido pelos estudantes, ao final das etapas de ensino, nos exames padronizados do INEP (Prova Brasil, para avaliar o ensino fundamental e Sistema de Avaliação da Educação Básica - Saeb, no tocante ao Ensino Médio).

Nesse sentido, no ano de 2010 a Câmara de Educação Básica do Conselho Nacional de Educação (CEB/CNE/MEC) emitiu o Parecer $n^{\circ} 08 / 2010$, no qual sinaliza que a construção de uma educação de qualidade para todos perpassa, sobretudo, pela:

valorização da carreira do magistério (valorização salarial, plano de carreira, formação inicial e continuada, e condições de trabalho), financiamento e gestão da educação, e estabelecimento de padrões mínimo de qualidade para nossas escolas públicas de Educação Básica (BRASIL, 2010). 
Em consonância com a legislação e após análise de estudos e pesquisas que visavam construir o marco de qualidade para a Educação Infantil, o Ensino Fundamental e o Ensino Médio, preconizado pelo inciso IX do artigo $4^{\circ}$ da LDB (BRASIL, 1996b), o CAQi proposto pela Campanha Nacional pelo Direito à Educação foi aprovado como referência para a construção da matriz de Padrões Mínimos de Qualidade para a Educação Básica Pública no Brasil pelo Parecer nº/2010 da Câmara de Educação Básica do Conselho Nacional de Educação do Ministério da Educação (CEB/CNE/MEC). Porém, para a sua implementação, depende-se, ainda, da sua homologação pelo ministro da educação.

Em novembro de 2013, o MEC instituiu, por meio da Portaria $n^{\circ} 1.140$, o Pacto Nacional pelo fortalecimento do Ensino Médio (PNEM). Com vistas a elevar o padrão de qualidade do Ensino Médio brasileiro, o Pacto entre União, Estados e Distrito Federal possui duas ações estratégicas articuladas: o redesenho curricular, com vistas à formação humana integral, a ser desenvolvido pelas escolas por meio do Programa Ensino Médio Inovador (ProEMI) e a formação continuada de professores do Ensino Médio. O Projeto de Redesenho Curricular (PRC) deve integrar o currículo existente às dimensões trabalho, ciência, cultura e tecnologia, conforme previsto nas Diretrizes Curriculares Nacionais para o Ensino Médio.

Sancionado em junho de 2014, o novo Plano Nacional de Educação, PNE 20142024, Lei 13.005/2014 (BRASIL, 2014), apresenta como Meta 7: "fomentar a qualidade da educação básica em todas as etapas e modalidades, com melhoria do fluxo escolar e da aprendizagem de modo a atingir as seguintes médias nacionais para o IDEB”:

Quadro 2: Metas para a Educação até 2021

\begin{tabular}{|l|c|c|c|c|}
\hline \multicolumn{1}{|c|}{ IDEB } & 2015 & 2017 & 2019 & 2021 \\
\hline Anos iniciais do ensino fundamental & 5,2 & 5,5 & 5,7 & 6,0 \\
\hline Anos finais do ensino fundamental & 4,7 & 5,0 & 5,2 & 5,5 \\
\hline Ensino Médio & 4,3 & 4,7 & 5,0 & 5,2 \\
\hline
\end{tabular}

Fonte: PNE 2014-2024 (BRASIL, 2014).

Ocorre que, segundo dados do IDEB (INEP, 2016c), o Ensino Médio no Brasil não progride desde 2011, quando a meta de 3,7 foi alcançada. Nos anos 2013 e 2015, o IDEB observado permaneceu em 3,7, quando deveria ter avançado para 3,9 e 4,3, respectivamente. A título de parâmetro internacional, o IDEB igual a 6, segundo o Parecer $n^{\circ} 8 / 2010$ da $\mathrm{CEB} / \mathrm{CNE} / \mathrm{MEC}$, corresponde aos padrões de qualidade dos países da Comunidade Europeia (BRASIL, 2010, p. 18). 
De acordo com a exposição de motivos apresentada pelo Ministro da Educação junto à Medida Provisória ${ }^{\circ} 746$, de 22 de setembro de 2016, apenas 58\% dos jovens de 15 a 17 anos estão no Ensino Médio e, em termos de proficiência, "mais de $75 \%$ dos alunos estão abaixo do esperado, e por volta de $25 \%$ encontram-se no nível zero, ou seja, mais de dois milhões de jovens não conseguem aplicar os conhecimentos adquiridos nas disciplinas de português e matemática" (BRASIL, 2016c).

Diante desse cenário, o Governo Federal propôs a Medida Provisória nº746 (BRASIL, 2016b), em 22 de setembro de 2016, a ser votada no Congresso Nacional. Denominada de Reforma do Ensino Médio, a MP propõe flexibilização curricular, com a possibilidade de itinerários formativos pela via tradicional ou técnica e profissional; aumento gradativo da carga horária e possibilidade de contratação de professores sem licenciatura. Alvo de manifestações contrárias e de ocupações atuais de escolas e universidades por estudantes, o fato é que a MP trouxe o tema para a agenda governamental e propiciou enxergar a diversidade de públicos envolvidos e a complexidade para se efetuar mudanças na área.

Posto isto, entre as estratégias previstas no PNE 2014-2024 (BRASIL, 2014) para o alcance dessa meta está o estabelecimento, pela União, em regime de colaboração com os entes federados subnacionais, no prazo de dois anos, de parâmetros mínimos de qualidade dos serviços da Educação Básica, a serem utilizados como referência para infraestrutura das escolas, recursos pedagógicos, entre outros insumos relevantes, bem como a criação de instrumento para adoção de medidas para a melhoria da qualidade do ensino (PNE 20142024, Estratégia 7.21).

O mesmo PNE 2014-2024 estabelece como estratégia para ampliar o financiamento público em educação pública básica (Meta 20) a utilização do índice Custo Aluno-Qualidade inicial (CAQi) estabelecido na legislação educacional. Estratégia 20.6:

No prazo de 2 (dois) anos da vigência deste PNE, será implantado o Custo AlunoQualidade inicial - CAQi, referenciado no conjunto de padrões mínimos estabelecidos na legislação educacional e cujo financiamento será calculado com base nos respectivos insumos indispensáveis ao processo de ensino-aprendizagem e será progressivamente reajustado até a implementação plena do Custo Aluno Qualidade - CAQ (BRASIL, 2014).

No âmbito internacional, o Brasil firmou compromisso em setembro de 2015, por ocasião da Cúpula das Nações Unidas para o Desenvolvimento Sustentável, na adoção dos Objetivos de Desenvolvimento Sustentável (ODS). Entre os objetivos está o de "assegurar educação inclusiva, equitativa e de qualidade, e promover oportunidades de aprendizagem ao 
longo da vida para todos", ODS 4, a ser alcançado pelo Brasil e pelo mundo até 2030. Entre as metas estabelecidas para esse alcance estão: garantir educação primária e secundária que conduza a resultados de aprendizagem relevantes e eficazes (ODS 4, Meta 4.1); "aumentar substancialmente o número de jovens e adultos que tenham habilidades relevantes, inclusive competências técnicas e profissionais, para emprego, trabalho decente e empreendedorismo" (ODS 4, Meta 4.4) e:

até 2030, garantir que todos os alunos adquiram conhecimentos e habilidades necessárias para promover o desenvolvimento sustentável, inclusive, entre outros, por meio da educação para o desenvolvimento sustentável e estilos de vida sustentáveis, direitos humanos, igualdade de gênero, promoção de uma cultura de paz e não-violência, cidadania global, e valorização da diversidade cultural e da contribuição da cultura para o desenvolvimento sustentável (ODS 4, Meta 4.7) (NAÇÕES UNIDAS, 2015).

Para isso, segundo as diretrizes previstas, os países devem aumentar substancialmente "o contingente de professores qualificados, inclusive por meio da cooperação internacional para a formação de professores, nos países em desenvolvimento" (ODS 4, Meta 4.c), o que amplia as possibilidades de capacitação docente nesse sentido.

\subsection{Contexto da Educação e do Ensino Médio no Brasil}

De acordo com as Diretrizes Curriculares Nacionais da Educação Básica, “a função precípua da educação, de um modo geral, e do Ensino Médio - última etapa da Educação Básica - em particular, vai além da formação profissional, e atinge a construção da cidadania" (BRASIL, 2013, p. 145). Segundo o documento:

[...] o Ensino Médio tem ocupado, nos últimos anos, um papel de destaque nas discussões sobre educação brasileira, pois sua estrutura, seus conteúdos, bem como suas condições atuais, estão longe de atender às necessidades dos estudantes, tanto nos aspectos da formação para a cidadania como para o mundo do trabalho. Como consequência dessas discussões, sua organização e funcionamento têm sido objeto de mudanças na busca da melhoria da qualidade. Propostas têm sido feitas na forma de leis, de decretos e de portarias ministeriais e visam, desde a inclusão de novas disciplinas e conteúdos, até a alteração da forma de financiamento. Constituem-se exemplos dessas alterações legislativas a criação do FUNDEB e a ampliação da obrigatoriedade de escolarização, resultante da Emenda Constitucional n ${ }^{\circ} 59$, de novembro de 2009 (BRASIL, 2013, p. 145).

Para que se tenha uma visão do cenário educacional brasileiro atual, apresenta-se a seguir alguns dados estatísticos. Segundo a Pesquisa Nacional por Amostra de Domicílios (PNAD) 2013-2014, realizada pelo IBGE, a taxa de analfabetismo das pessoas de 15 anos ou mais de idade no Brasil, no ano de 2014, foi estimada em 8,3\% (13,2 milhões de pessoas). Em 
2013, esse indicador havia sido 8,5\% (13,3 milhões de pessoas). A região Centro-Oeste manteve a taxa de 6,5\% nos dois anos (IBGE, 2015, p. 42).

Gráfico 1: Taxa de analfabetismo das pessoas de 15 anos ou mais de idade, segundo as Grandes Regiões no Brasil - 2013-2014

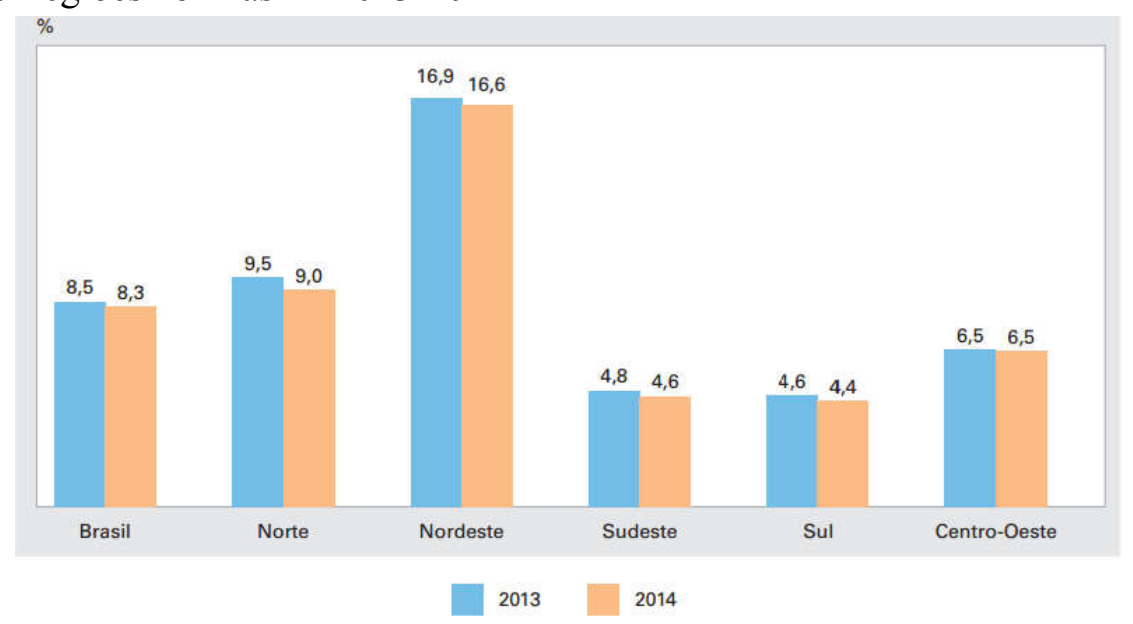

Fonte: IBGE, 2015, p. 42

Em relação às faixas etárias, nota-se que este indicador aumenta à medida que a idade avança. No grupo entre 15 e 19 anos, o analfabetismo caiu de 1\% para 0,9\% nos anos de 2013 e 2014. E, entre os grupos etários de 20 a 24 anos e 25 a 29 anos, no ano de 2014, esse índice foi de $1,4 \%$ e 2,1\%, respectivamente, conforme demonstrado no Gráfico 2.

Gráfico 2: Taxa de analfabetismo das pessoas de 15 anos ou mais de idade, segundo os grupos de idade - Brasil - 2013-2014

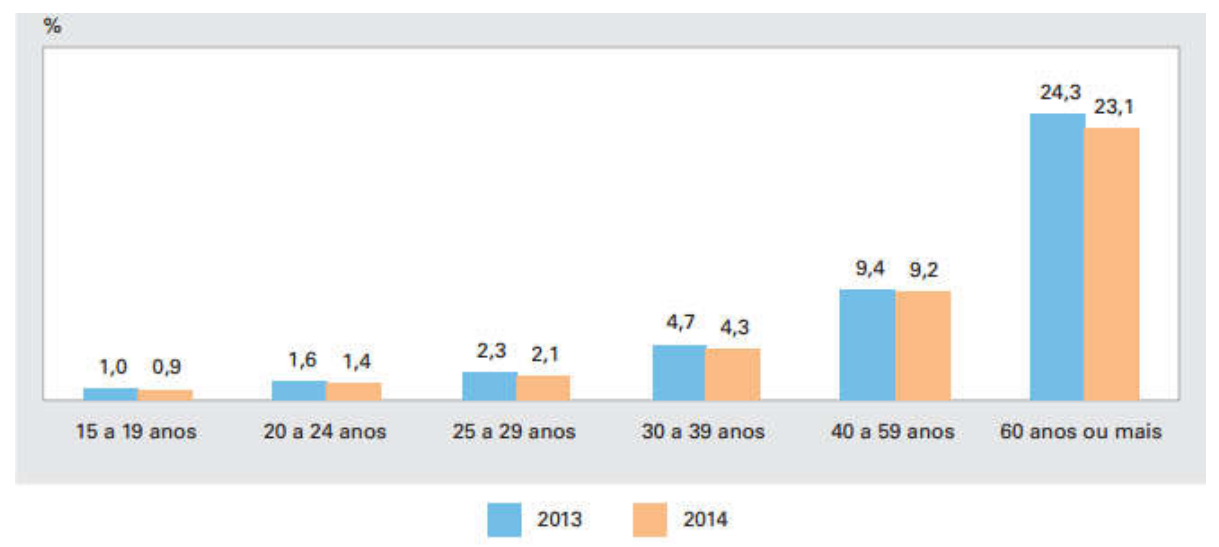

Fonte: IBGE, 2015, p. 43.

Além do analfabetismo pleno, é preciso destacar o alto índice de analfabetos funcionais no País. De acordo com a PNAD 2013-2014 (IBGE, 2015, p. 43), é considerado analfabeto funcional aquele indivíduo com 15 anos ou mais, que possui menos de quatro anos de estudo, o que soma cerca de $20 \%$ dessa população. Segundo a PNAD, a região nordeste 
lidera a taxa de analfabetismo funcional, com 27,1\% em 2014. A região Centro-Oeste, por sua vez, detém $16,1 \%$.

Gráfico 3: Taxa de analfabetismo funcional das pessoas de 15 anos ou mais de idade, segundo as Grandes regiões - Brasil - 2013-2014

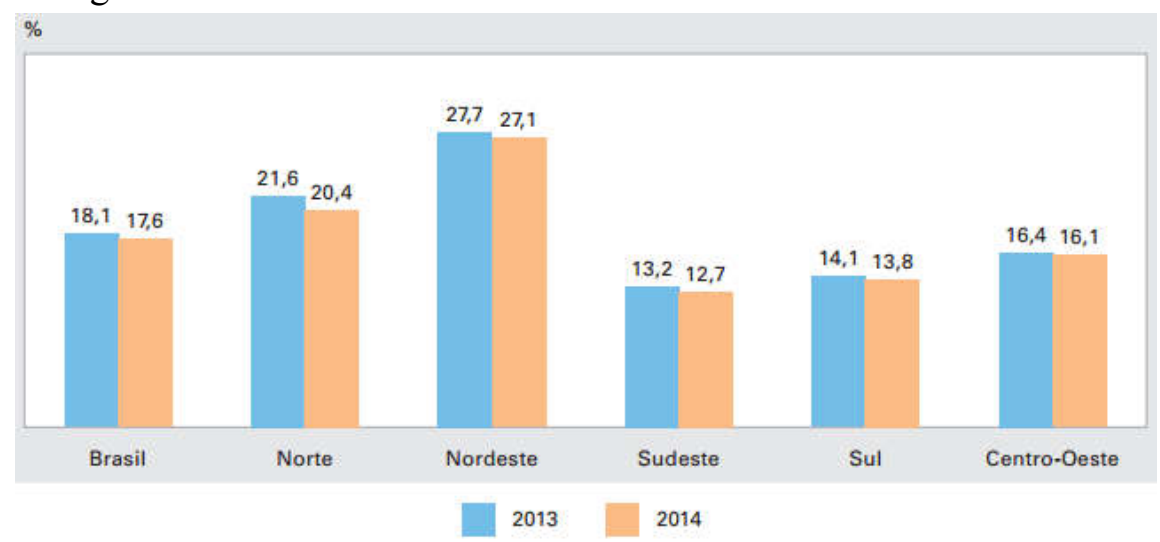

Fonte: IBGE, 2015, p. 44.

Para um melhor entendimento da situação da educação nacional, conforme demonstrado no Gráfico 4, a PNAD indica que da população com 25 anos ou mais de idade, no ano de 2014, 12\% não possui instrução ou menos de 1 ano de estudo; $32 \%$ possui ensino fundamental incompleto; fundamental completo soma 9,5\%; Ensino Médio incompleto eram 4,2\% desse público e apenas 25,5\% concluíram o Ensino Médio; superior incompleto, 4\% e completo $13 \%$. Isso significa que, de toda a população brasileira com mais de 25 anos, em 2014, cerca de 60\% não havia cursado Ensino Médio completo (IBGE, 2015, p. 44).

Diante desse cenário desafiador, é premente a necessidade de aperfeiçoamento da gestão educacional brasileira. Para se repensar a questão no País, ouvir atores locais que implementam a educação escolar pode ser uma estratégia que traga à luz elementos que contribuam para a reflexão de como implementar uma educação de melhor qualidade, que atraia os jovens. Além disso, atentar para o que os beneficiários da política, no caso os educandos, tem a nos indicar sobre o que faz diferença para um aprendizado mais satisfatório na escola, pode auxiliar no alinhamento de interesses e, consequentemente, no alcance de um resultado mais efetivo. 
Gráfico 4: Distribuição percentual das pessoas de 25 anos ou mais de idade, segundo o nível de instrução - Brasil - 2013-2014

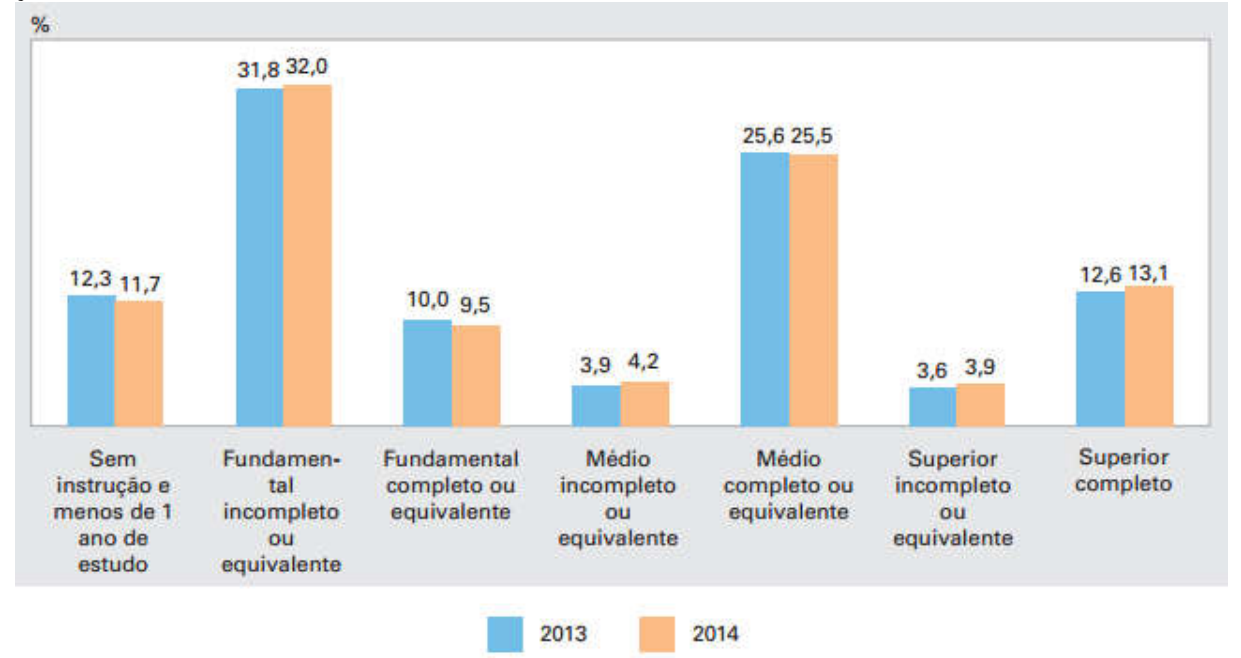

Fonte: IBGE, 2015, p. 44.

Ciclo final da educação básica, o Ensino Médio no Brasil tornou-se etapa obrigatória somente a partir da Emenda Constitucional n $n^{\circ} 59 / 2009$, a qual preconiza que a educação básica deve ser "obrigatória e gratuita dos 4 aos 17 anos de idade, assegurada inclusive sua oferta gratuita para todos os que a ela não tiveram acesso na idade própria" (art. $\left.1^{\circ}, \mathrm{EC} \mathrm{n}^{\circ} 59 / 2009\right)$.

Essa Emenda estabelece, ainda, o prazo até o ano de 2016 para que a educação básica seja progressivamente implementada, "nos termos do Plano Nacional de Educação, com apoio técnico e financeiro da União".

Por conseguinte, o Plano Nacional de Educação, PNE 2014-2024, apresenta como terceira meta a universalização do atendimento escolar para toda a população de 15 a 17 anos até o ano de 2016, e elevar, até o ano de 2024, a taxa líquida de matrículas no Ensino Médio para $85 \%$ (oitenta e cinco por cento).

Para o alcance dessa meta, uma das estratégias previstas no PNE 2014-2024 é:

\begin{abstract}
Estratégia 3.1) institucionalizar programa nacional de renovação do Ensino Médio, a fim de incentivar práticas pedagógicas com abordagens interdisciplinares estruturadas pela relação entre teoria e prática, por meio de currículos escolares que organizem, de maneira flexível e diversificada, conteúdos obrigatórios e eletivos articulados em dimensões como ciência, trabalho, linguagens, tecnologia, cultura e esporte, garantindo-se a aquisição de equipamentos e laboratórios, a produção de material didático específico, a formação continuada de professores e a articulação com instituições acadêmicas, esportivas e culturais [...](BRASIL, 2014).
\end{abstract}

Segundo Jaqueline Moll e Sandra Garcia, respectivamente, Diretora de Currículos e Educação Integral e Coordenadora Geral de Ensino Médio da Secretaria de Educação Básica 
do Ministério da Educação em 2013, a “crise atual do Ensino Médio não é mais do que a explicitação da ausência histórica dessa etapa educativa como possibilidade de todos, agravada por uma profunda perda de sentido identitário e pedagógico da instituição escolar" (in DAYRELL, CARRANO, MAIA, 2014, p. 7 e 8).

Para Moll e Garcia, o enfrentamento dessa crise não perpassa "saídas simples, receitas, roteiros predeterminados", que, como aconteceu no passado, prenda "as escolas de Ensino Médio em fazeres dissociado da compreensão da amplitude da tarefa formativa nesse momento da vida dos jovens e, principalmente, dissociados dos sujeitos jovens que muito têm a dizer de si, dos seus sonhos, dos seus projetos, dos seus saberes" (in DAYRELL, CARRANO, MAIA, 2014, p. 8). Daí a importância de se ouvir e de se compreender o público alvo da política.

\subsection{Qualidade da educação: das concepções ao desafio da implementação}

Estudos têm apontado que a causa de muitos fracassos governamentais em alcançar os objetivos das políticas deve-se a fatores relacionados à implementação de políticas públicas. O processo de implementação tem sido considerado pela literatura científica o "elo perdido" dentro da análise da ação governamental. Por esse motivo, Silva e Melo defendem que "as avaliações de políticas públicas, programas e projetos, devem focar de forma privilegiada o processo de implementação" (SILVA, MELO, 2000, p. 3).

$\mathrm{Na}$ visão tradicional, a implementação faz parte do ciclo de políticas públicas e corresponde à mera execução de atividades previamente estabelecidas de forma racional pelos formuladores da política, com vistas ao alcance dos resultados almejados. Para essa corrente, o insucesso da política deve-se, principalmente, a problemas na formulação.

Na perspectiva linear, as dificuldades de implementação são imputadas a fatores relacionados à incapacidade institucional dos implementadores; ou, de natureza política, ou, ainda, a fatores correlacionados a resistências e sabotagens de grupos contrários à política (SILVA, MELO, 2000).

Para além da visão tradicional e da perspectiva linear, Silva e Melo apontam que "estudos de situações concretas revelam um padrão muito distinto, onde prevalece a troca, a negociação e barganha, o dissenso e a contradição quanto aos objetivos" (SILVA, MELO, 2000, p. 9).

Conforme explicam os autores, o foco da literatura tem residido prioritariamente no governo e não em outros setores ou entidades que afetam de forma direta ou indireta a 
implementação. Isso tem ocasionado uma lacuna nos estudos sobre os fatores ambientais e as influências de contexto existentes, que afetam os processos de implementação. Por isso, recomendam que a implementação seja estudada como um "processo autônomo onde decisões cruciais são tomadas” pelos executores da política (SILVA, MELO, 2000, p. 10).

Nesse sentido, partindo-se do pressuposto que os implementadores representam e respondem pelo Estado, Lotta (2012) defende que se torna necessário o entendimento da ação e interação realizadas por eles para se compreender a ação efetiva do Estado.

De acordo com Lima e Medeiros (2012), a literatura tem apontado a atuação dos agentes que interagem diretamente com o público-alvo ou beneficiários das políticas públicas como um dos fatores que influenciam a implementação, tendo em vista possuírem poder discricionário na execução das ações.

Segundo Oliveira (2012), quando o legislador não consegue equalizar os conflitos existentes entre os diversos atores envolvidos, transfere o problema para a área administrativa, ou seja, para aqueles que irão materializar a política pública em ações. Isso, por sua vez, dá, aos executores das políticas públicas, um poder discricionário para irem além da decisão de aplicá-las ou não, pois têm de julgar os significados delas e os resultados que elas almejam, ampliando a ação discricionária dos executores imediatos.

Esses agentes que interagem diretamente com os cidadãos, e que possuem grande discricionariedade na execução de suas tarefas foram denominados por Lipsky (1980) de "burocratas de nível de rua" e por Oliveira (2012) de "burocratas da linha de frente".

Segundo Oliveira, a atuação dos burocratas da linha de frente pode ser decisiva na implementação de uma política pública, pois são eles que traduzem os programas em bens e serviços à sociedade. De acordo com o autor, a literatura tem apontado que "os resultados da implementação são dependentes das burocracias, pois elas desempenham papel capital não só na execução das politicas que alocam recursos públicos, como também na própria tomada de decisão sobre quem ganha o quê do governo" (OLIVEIRA, 2012, p. 1553).

Ademais, de acordo com o mesmo autor, a literatura tem apontado a distância existente entre os políticos e os administradores do topo e os burocratas da linha de frente, pois os primeiros enxergam os cidadãos como abstrações, enquanto os burocratas da base encaram os cidadãos como indivíduos concretos. No trabalho cotidiano essa situação proporciona, nos agentes executores, a percepção de que seus superiores estão distanciados da realidade e que os programas por eles elaborados são impraticáveis. Isso leva esses burocratas a duvidarem "de que as autoridades estejam realmente preocupadas em solucionar os problemas da sociedade". Esse distanciamento pode contribuir para que os agentes venham a 
duvidar da legitimidade dos gestores, que por sua vez poderá levá-los a ignorar as diretrizes da hierarquia (OLIVEIRA, 2012, p. 1557).

Transportando essas visões para o campo da educação pública formal, torna-se importante compreender como se dá a implementação da qualidade educacional na ponta. Quais são os desafios postos à comunidade escolar, composta por aqueles que efetivamente implementam e transformam em realidade a política pública educacional, pensada e formulada por legisladores e corpo técnico da alta burocracia governamental, seja ela federal, estadual ou, ainda, distrital.

Nesse sentido, do ponto de vista da política educacional, o papel de articulação política e institucional compete ao diretor escolar; a função administrativa, ao corpo administrativo escolar; já o papel efetivo de interação social com os educandos (foco da melhoria da qualidade educacional), de interface entre os aprendizes e o campo abstrato do conhecimento e dos valores a serem incentivados ou não em sociedade, fica a cargo dos professores, tendo a coordenação pedagógica a atribuição de melhor analisar e orientar esse processo. Nesse contexto, a depender do aspecto a ser analisado, pode-se compreender toda a comunidade escolar: diretor, corpo administrativo, coordenador pedagógico e docentes, como sendo os burocratas da linha de frente da política educacional.

Apesar da delegação de atribuições ser feita a papeis, em especial no tocante à implementação de políticas públicas, essa divisão envolve indivíduos que tem interesses e objetivos que nem sempre estão alinhados com os do sistema formal. Por isso, a execução da política pública no plano micro depende da discricionariedade dos burocratas de nível de rua.

Segundo Lotta (2012), para se analisar a atuação dos burocratas faz-se necessário compreender de que maneira esses atores constroem suas ações, considerando que esses fazem parte de uma estrutura programática e institucional e, ao mesmo tempo, têm o poder de implementar políticas públicas. De acordo com o autor, mesmo que dimensões políticas oficiais moldem alguns padrões e normas comunitárias e administrativas, os implementadores conseguem ter autonomia para decidir como aplicá-las e inseri-las nas práticas da implementação.

Ademais, é importante salientar que, de acordo com Silva e Melo os seguintes fatores precisam ser considerados na análise da implementação de políticas públicas:

o contexto institucional e organizacional brasileiro caracteriza-se por especificidades importantes - dentre as quais se destacam sua complexidade e forte diferenciação funcional, e principalmente os problemas de coordenação e cooperação intergovernamentais (SILVA, MELO, 2000, p. 3). 
No mesmo sentido, Lima e Medeiros (2012) apontam que, apesar das políticas e programas governamentais serem formulados e definidos para serem implementados de forma homogênea em todo o Brasil, a implementação dessas políticas e programas varia muito dependendo da localidade, mesmo que haja semelhança nas instituições ou órgãos.

Segundo Arretche (2001), a diversidade de contextos de implementação pode fazer com que a mesma regulamentação produza resultados diversos em realidades diferentes.

Para Lotta (2012), no cotidiano dos burocratas, observa-se uma série de interações realizadas com os sistemas político, institucional, organizacional e comunitário, inerentes à sua função, trazendo impacto e influência em sua capacidade de ação e, consequentemente, no processo de implementação de políticas públicas.

Por fim, conforme destaca Cavalieri “é preciso lembrar que a escola é, por natureza, a instituição do aluno e para o aluno. Com todas as suas limitações, é a instituição onde o aluno é sempre a parte principal, onde seu lugar é um direito constitucional" (CAVALIERI, 2007, p. 1031). Esse é o foco deste trabalho. 


\section{METODOLOGIA}

\subsection{Abordagem, natureza e tipos de pesquisa}

A presente pesquisa insere-se nas áreas de gestão pública e educação, campo das pesquisas sociais aplicadas. Trata-se de uma pesquisa qualitativa, de caráter descritivo e exploratório, pela qual se visa identificar e analisar os principais desafios para a implementação de Ensino Médio de qualidade a partir do olhar de uma comunidade escolar.

De acordo com Denhardt (2012), existe uma crise de legitimidade na administração pública convencional, segundo a qual a teoria não reflete as necessidades dos atores do campo - teóricos, profissionais e cidadãos. Por isso, o estudo visa ouvir os atores diretamente envolvidos com a implementação da política educacional e, a partir da realidade vivida, dos desafios expostos, contribuir com subsídios para o aperfeiçoamento do Ensino Médio.

Para o alcance desse objetivo, a construção de um referencial teórico que dê base ao estudo, se faz fundamental. Nesse sentido, definiram-se como categorias centrais da revisão de literatura e da pesquisa bibliográfica os termos: qualidade em educação, Ensino Médio e implementação de políticas públicas.

Salienta-se que, para este estudo, a comunidade escolar compõe-se dos seguintes atores: diretor da instituição escolar, coordenador pedagógico, docentes e educandos, públicoalvo da política educacional.

Conforme apontado pela literatura, o termo qualidade em educação é complexo, polissêmico e varia conforme o tempo histórico e o referencial de análise. No presente estudo, busca-se investigar qual é o conceito compreendido pelos componentes da comunidade escolar analisada e como ele tem sido desenvolvido na prática. A partir daí, visa-se analisar os principais desafios para a sua implementação.

Para a realização da pesquisa, utilizaremos o método de Estudo de Caso Múltiplo, apregoado por Yin (2001) como uma pesquisa empírica que investiga um fenômeno contemporâneo em seu contexto real, podendo ser utilizado como etapa exploratória na pesquisa de fenômenos pouco investigados.

Por se tratar de uma pesquisa empírica, optou-se pela estratégia do Estudo de Caso tendo em vista o método propiciar a investigação de um "fenômeno contemporâneo dentro de seu contexto de vida real" (YIN, 2001, p. 32) e preservar as características holísticas e significativas do evento concreto. Trata-se de um método abrangente que possibilita o uso 
de múltiplas fontes de evidências (entrevistas semiestruturadas, questionários, pesquisas bibliográfica e documental) e engloba a lógica do design, a técnica da coleta de dados e abordagens para análise dos mesmos.

De acordo com pesquisa realizada por Soares e Candian:

[...] depois que as diferenças nos antecedentes familiares dos alunos são controladas, há escolas cujos alunos tem desempenho muito melhor que os de outras, indicando que seus projetos pedagógicos e formas de gestão são mais adequados à realidade brasileira. Por outro lado, as variáveis coletadas nos questionários contextuais não permitem identificar quais fatores as tornam mais efetivas (SOARES, CANDIAN, 2007, p. 16).

Nesse sentido, Soares e Candian recomendam que estudos quantitativos de projetos de avaliação educacional "devem ser seguidos de estudos de caso, que descrevam na sua totalidade as escolas de sucesso, de forma que sua experiência possa ser utilizada por outras escolas (SOARES, CANDIAN, 2007, p. 16).

De acordo com Lüdke e André (1988), o material obtido em estudos de cunho qualitativo é rico em descrições de pessoas, situações e acontecimentos, pois estudam os problemas no ambiente em que ocorrem naturalmente e consideram os pontos de vista dos participantes. Isso propicia verificar como a questão estudada se manifesta nas atividades, nos procedimentos e nas interações cotidianas. Segundo os autores, o intuito não é buscar evidências que comprovem hipóteses, mas analisar criticamente os problemas, buscando uma compreensão contextualizada da realidade.

$\mathrm{Na}$ tipologia de Jensen e Rodgers (2001), a presente pesquisa caracteriza-se como estudos de caso acumulativos, que descreve duas organizações, num determinado período de tempo, no caso, duas escolas públicas regulares de Ensino Médio que obtiveram as melhores notas no ENEM nas edições 2014 e 2015.

Nesse sentido, objetiva-se compreender o caso em si, sem interesse em inferências teóricas ou generalizações empíricas futuras. Conforme Stake nos ensina "mesmo um estudo de caso intrínseco pode ser visto como um pequeno passo em direção a uma grande generalização" (STAKE, 2000, p. 439).

Dessa forma, a partir da análise da realidade, tem-se o intuito de possibilitar, a quem assim desejar, a generalização analítica (YIN, 2001, p. 29). Esse tipo de estudo sugere que, ao invés do pesquisador assumir a responsabilidade de definir para que contextos os resultados obtidos possam ser generalizados, o estudo deixará essa decisão para o leitor. 


\subsection{Critérios de seleção das escolas pesquisadas}

O primeiro critério utilizado para escolha das duas escolas a serem pesquisadas foi ser escola pública regular de Ensino Médio do Distrito Federal. Com isso, escolas privadas, militares, profissionalizantes e federais foram excluídas do processo de seleção tendo em vista suas características peculiares (entre elas, fonte de financiamento e normatizações diferenciadas).

Como segundo critério arbitrou-se a utilização das notas alcançadas pelas escolas no ENEM nas edições de 2012, 2013 e 2014 (INEP, 2013; INEP, 2014c; INEP, 2015b). Dessa forma, as duas escolas a pesquisadas deveriam estar entre as cinco mais bem colocadas na edição do ENEM 2014, resultado mais atualizado disponível à época da escolha. Ademais, por se tratar de pesquisa sobre qualidade educacional, optou-se por selecionar a primeira colocada nessa edição para se investigar como se dá, na ponta, essa implementação. Contudo, tendo em vista diversas tentativas e a dificuldade de agenda do corpo diretivo dessa escola, optou-se por pesquisar a segunda mais bem classificada no ano de 2014, dentro dos parâmetros estabelecidos, a qual denominamos no trabalho de Escola A. Outro critério utilizado para a seleção da segunda escola a ser pesquisada foi ter obtido sucessiva melhora na classificação nas edições do ENEM 2012-2013 e 2013-2014. Assim, segunda escola selecionada, denominada Escola B, de uma posição de $24^{\circ}$ lugar em 2012 galgou a $21^{\text {a }}$ colocação em 2013 e o $5^{\circ}$ lugar em 2014. Com isso, buscou-se apurar o que tem sido realizado nessa escola, nos últimos anos, para que o desempenho dos alunos tenha melhorado significativamente no ENEM. A título de informação, salienta-se que a Escola A tem estado entre as três melhores posições no ENEM nas edições de 2012 a 2015. Apenas para fins de acompanhamento do rendimento no ENEM, em 2015 a Escola B obteve a $7^{\mathrm{a}}$ posição entre as escolas públicas regulares do DF.

É importante destacar que, tendo em vista não haver dados do IDEB por escola referentes ao Ensino Médio, não foi possível o uso desse índice para a escolha das escolas a serem pesquisadas. Houve a solicitação dessa informação junto ao INEP, porém, o instituto informou que não calcula o IDEB por escola e município para o Ensino Médio devido ao fato de a aplicação do Saeb, nesta etapa de ensino, ser amostral. Por esse motivo, na presente pesquisa foi arbitrado o uso dos resultados das escolas no ENEM como critério de escolha das unidades de pesquisa.

Cabe observar que, primeiramente, buscou-se compreender, no conjunto das escolas analisadas, qual o horizonte de qualidade concebido e almejado, tanto por estudantes 
quanto por profissionais do ensino. Então, contrastar essa visão com os conceitos apresentados pela literatura e, a partir disso, investigar quais são os principais desafios para o alcance de um ensino de melhor qualidade na ponta.

Ressalta-se que o estudo não tomou como parâmetro de qualidade os resultados obtidos no ENEM, que serviram tão somente como um critério para escolha das unidades a serem pesquisadas. Apesar da sociedade, de uma maneira geral, qualificar as escolas de acordo com a colocação no referido exame, o estudo buscou investigar antes qual o conceito que os profissionais de educação na ponta, burocratas de nível de rua (LIPSKY, 1980), têm sobre qualidade do Ensino Médio. Assim como, se essa avaliação da sociedade de modo geral sobre o ENEM corresponde ao entendimento desses profissionais também. Por essa razão, esse exame foi abordado em duas questões aplicadas na pesquisa.

Outro aspecto a ser destacado é, ainda que alunos das escolas do Plano Piloto possam ser, de certo modo, auto selecionados, ou seja, procuram estudar nessas escolas em busca de melhor qualidade do ensino e/ou de maior chance de ingresso em uma universidade pública e por isso, já possuem algum grau de propensão maior ao estudo, esse fato não prejudica a pesquisa das escolas escolhidas. Pelo contrário, corrobora com o estudo sobre qualidade do Ensino Médio uma vez que se tem a opinião daqueles que buscam educação de melhor qualidade na rede pública de ensino.

Ademais, é prudente salientar que o presente estudo não tem a pretensão de oferecer soluções conclusivas para questões aqui apresentadas, mas, antes, propiciar reflexões a partir das visões apresentadas pela comunidade escolar, incluindo nela, diretor(a), coordenadores(as) pedagógicos(as), docentes e estudantes - beneficiários do serviço prestado.

Outrossim, observa-se que os principais desafios apontados nesse estudo para o alcance de uma educação pública de melhor qualidade partem de uma condição preexistente, de estrutura mínima já constituída por essas escolas, a qual está relatada no próximo capítulo.

\subsection{Instrumentos de Coleta de Dados}

Para o alcance do objetivo principal, foram realizadas pesquisas documental e bibliográfica nacional e internacional, referentes à concepção de qualidade em educação. Também foram analisados documentos normativos, tais como leis e decretos; Parecer Executivo, Resolução, artigos científicos, dissertações de mestrado, teses acadêmicas, livros e relatórios técnicos. 
Em relação aos casos específicos, foi realizada pesquisa documental, entrevista semiestruturada à direção escolar (compreendida, nessa pesquisa, quem exerce a função de diretor), assim como se aplicou questionários à comunidade escolar: diretor, docentes, coordenação pedagógica e estudantes, os quais estão disponíveis como anexos.

Em relação à entrevista, foram realizadas duas, uma com cada dirigente escolar, as quais tiveram duração de $2 \mathrm{~h} 20$ minutos cada. A entrevista com a direção da escola A é citada no trabalho como E1; já a entrevista com a direção da escola B, E2. Cumpre informar que na escola B houve a participação esporádica da vice-diretora na entrevista, porém, como havia alinhamento de percepções com a dirigente, sua opinião não foi diferenciada no presente trabalho.

Cumpre informar que os questionários foram elaborados a partir dos principais temas apontados e discutidos na literatura e em documentos da sociedade civil organizada e de organismos internacionais. Adianta-se que esses temas foram posteriormente analisados por meio de seis categorias.

Optou-se por aplicar questionário a todos os docentes e alunos do Ensino Médio regular das escolas pesquisadas, assim como à direção e à coordenação pedagógica, em razão de acreditar-se que a qualidade educacional depende do entendimento, da dedicação e da criatividade individual de cada um e do trabalho coletivo entre docentes, direção, coordenação pedagógica e estudantes. Apesar da importância dos demais profissionais presentes no ambiente escolar, a pesquisa restringiu-se a esses públicos.

Para a coordenação pedagógica e o público docente os questionários foram semelhantes, distinguindo apenas na primeira parte, referente ao perfil do profissional. A segunda parte conteve 6 questões subjetivas e 4 semiabertas, todas voltadas ao tema qualidade em educação.

Aos estudantes aplicou-se questionário também composto por duas partes. Uma relacionada ao perfil do aluno e à formação escolar de pais ou responsáveis, visando compreender o contexto no qual se insere o indivíduo. E outra parte composta por cinco questões objetivas.

Para melhor captar o entendimento de cada público sobre os mesmos assuntos, aplicaram-se as mesmas questões objetivas, com adaptação do enunciado ao público respondente, à comunidade escolar pesquisada. Com isso, buscou-se a percepção dos diversos públicos sobre os mesmos conteúdos. Ao todo foram 5 questões semelhantes aos estudantes, à coordenação pedagógica e aos docentes. Dessas, 4 questões foram também aplicadas à 
direção escolar, sendo duas em meio impresso e duas inseridas na entrevista. Para melhor análise desses tópicos, construiu-se gráfico radar, também conhecido como gráfico polar.

Entre as questões semelhantes aplicadas à comunidade escolar estão duas de múltipla escolha, quais sejam: a) Q3-Alunos, correspondente à Q6 - Docentes e Coordenação e Q1- Direção; b) Q5-Alunos, Q8 - Docentes e Coordenação e Q2- Direção. Adaptado o enunciado da primeira ao público respondente, as perguntas seguem na sequência.

- (Q3-Alunos) Com vistas a uma melhor formação, marque as áreas abaixo que você gostaria que a escola explorasse mais ou promovesse atividades extracurriculares (pode marcar mais de $1 \mathrm{vez}$ ):

- (Q6 - Docentes e Coordenação e Q1- Direção) Com vistas à melhoria da qualidade da educação ofertada, marque abaixo as áreas que deveriam ser enfatizadas ou promovidas atividades extracurriculares na escola:

- (Q5-Alunos, Q8 - Docentes e Coordenação e Q2- Direção) Em sua opinião, o que precisa ser feito para melhorar a qualidade do Ensino Médio nessa escola?

Em ambas, os participantes puderam escolher mais de uma opção como resposta. O intuito foi buscar descobrir possíveis demandas da comunidade escolar, assim como sinalizações para o alcance de uma educação de melhor qualidade.

\subsection{Análise de Dados}

A partir dos principais temas debatidos na literatura (CARREIRA, PINTO, 2011; TIKLY, 2010; RIVKIN, HANUSHEK, KAIN, 2005), em relatórios internacionais da Unesco (2005; 2014) e em documento elaborado sob coordenação conjunta da Ação Educativa, do Fundo das Nações Unidas para a Infância (Unicef), do Programa das Nações Unidas para o Desenvolvimento (PNUD) e do INEP (AÇÃO EDUCATIVA et al, 2004) foram estabelecidas as seguintes categorias de análise:

1. Ambiente educativo/clima organizacional;

2. Prática pedagógica;

3. Avaliação do estudante;

4. Gestão escolar;

5. Formação e condições de trabalho dos docentes;

6. Ambiente físico escolar (infraestrutura e recursos escolares).

Cumpre informar que os itens-resposta de uma das questões de múltipla escolha aplicada (questão 5 aplicada aos alunos; questão 8, aos docentes e coordenação pedagógica e questão 2 , à direção), referente ao que precisa ser feito para melhorar a qualidade do Ensino 
Médio na escola, foram elaborados com base na coleção Indicadores da Qualidade na Educação (AÇÃO EDUCATIVA, 2004).

Salienta-se que, a princípio as categorias analisadas restringir-se-iam ao âmbito intraescolar, de governabilidade da direção da escola e de sua equipe. Porém, com a aplicação da pesquisa, surgiu a necessidade de se acrescentar na análise duas categorias: "Políticas Públicas" e "Família". A primeira pelas condições legais impostas pelos poderes governamentais distrital e federal sobre as unidades escolares. A segunda que, inicialmente, seria apontada apenas na contextualização do aluno, acabou sendo incorporada na análise por ter sido destacada por diversos profissionais como importante fator que influi no sucesso escolar do estudante. O que vai ao encontro de análises realizadas por autores e organismos internacionais (UNESCO, 2005 e 2014; TIKLY, 2010).

Como critério para interpretação dos dados foi realizada análise de conteúdo com base na literatura de Franco (2003) e Bardin (2010), e contrastada as informações obtidas com as características identificadas no referencial teórico.

Ressalta-se que o presente estudo não tem o intuito de avaliar o sistema educacional posto, a ideologia defendida, suas fragilidades ou contradições, mas analisar os principais desafios vivenciados na prática por aqueles que implementam a política educacional no País. Desafios esses enfrentados por quem desempenha o papel de diretor, coordenador pedagógico, docente e estudante.

Dessa forma, o estudo tem como pressupostos:

a) A qualidade medida por avaliação externa, como o ENEM, não corresponde necessariamente à qualidade almejada pelos implementadores;

b) A burocracia de base possui papel fundamental não apenas na implementação de um Ensino Médio de melhor qualidade como também nas etapas de elaboração e avaliação da política pública educacional.

\section{Participantes da pesquisa}

\section{Escola A}

Ao todo participaram da pesquisa na escola A: 1 dirigente, 2 coordenadores pedagógicos, 13 docentes e 339 estudantes.

No tocante ao público docente da escola $\mathrm{A}$, cabe informar que parte ofereceu resistência em responder ao questionário aplicado. De um total de 30 docentes que atuam em sala de aula, 13 responderam à pesquisa, o que corresponde a $43 \%$ da população local em 
regência de classe. Em relação ao turno, colaboraram seis professores do período matutino ( $2^{\circ}$ e $3^{\circ}$ anos $)$ e sete do vespertino ( $1^{\circ}$ e $2^{\circ}$ anos $)$.

Em relação aos estudantes da escola A, de um total de 827 alunos do Ensino Médio regular em 2016, conforme Censo Escolar 2016 (DISTRITO FEDERALb, 2016), responderam ao questionário aplicado 339 estudantes, o que corresponde a $40 \%$ da população. De acordo com cálculos estatísticos de Levin (1987) e Levine (2000), essa amostra possui um grau de confiabilidade no resultado de $98,29 \%$ com margem de erro de $5 \%$.

Na Escola A, a entrevista e a aplicação dos questionários aos públicos docente, discente e coordenação pedagógica foi no mês de julho de 2016. A primeira tentativa foi desestimulada pela direção e pela coordenação pedagógica em razão de se tratar de semana de revisão de conteúdos em sala de aula e de preparação de provas, momento em que os docentes não dispunham de tempo. Por esse motivo, fomos orientados a realizar a pesquisa duas semanas mais tarde, período posterior à aplicação e à correção das provas. Momento mais propício aos docentes, porém, com reduzido número de estudantes na escola em razão de se tratar de véspera de férias.

\section{Escola B}

Em relação à escola $\mathrm{B}$, contribuíram com a pesquisa: 1 dirigente, 1 coordenador $\mathrm{e}$ 1 supervisor pedagógico, 1 orientador educacional, 15 docentes e 415 estudantes.

No tocante à coordenação pedagógica, esclarece-se que a escola B possui, para a etapa do Ensino Médio, dois coordenadores pedagógicos, um que trabalha no período matutino e um no noturno. Como este último não respondeu ao questionário, apesar das várias tentativas, com vistas a se obter maiores informações sobre o noturno, convidou-se a participar da pesquisa uma supervisora pedagógica e uma orientadora educacional, as quais gentilmente se disponibilizaram a responder ao questionário adaptado, aplicado aos coordenadores. Para que o anonimato dos participantes fosse preservado, optou-se por expor os resultados dessas profissionais em conjunto com o do coordenador pedagógico do matutino, mantendo-se a nomenclatura nos quadros e nas análises como coordenação pedagógica.

Em relação ao público docente, trabalham na escola B, ao todo, 24 professores no Ensino Médio regular, sendo 13 no matutino e 11 no noturno. Cumpre esclarecer que a aplicação dos questionários ao público docente seguiu dois momentos distintos. Para os profissionais do turno matutino, a coordenação pedagógica autorizou a aplicação dos questionários ao final da reunião geral de coordenação, em julho de 2016. Apesar dos 
docentes terem levado cerca de meia hora respondendo às 7 questões propostas, o que demonstrou intuito de colaboração com a pesquisa, percebeu-se que as respostas às questões abertas eram genéricas e não traziam, de certo modo, direcionamento para se compreender os desafios postos na prática. Por esse motivo, após uma semana aplicou-se questionário complementar contendo três questões adicionais.

No período noturno, como não havia coordenação pedagógica com todos os docentes ao mesmo tempo, a pesquisadora visitou a escola três dias do mês de julho, porém, obteve o retorno de apenas um docente. Para que a pesquisa não prescindisse do noturno, foi necessária a ida da pesquisadora à escola por mais 6 vezes no mês de agosto, quando se obteve mais 4 respostas.

Assim, em resumo, na pesquisa de campo realizada na escola $\mathrm{B}$, de 13 docentes do diurno, 10 responderam ao questionário; e de 11 professores do noturno, 5 participaram da pesquisa. Com isso, ao todo 15 docentes colaboraram com a pesquisa.

Em relação ao público discente da escola B, de um total de 457 alunos do Ensino Médio regular em 2016, conforme Censo Escolar 2016 (DISTRITO FEDERALb, 2016), responderam ao questionário aplicado 415 estudantes, o que corresponde a 90\% da população. De acordo com cálculos de Levin (1987) e Levine (2000), essa amostra corresponde a um grau de confiabilidade no resultado de $99 \%$ com margem de erro de $2 \%$.

Cabe informar que duas limitações foram percebidas durante a aplicação da pesquisa de campo. Uma relativa ao gênero dos alunos: previu-se feminino e masculino, mas não uma terceira classificação, demandada por estudantes. Outro aspecto refere-se ao tema esporte, não previsto na pergunta objetiva do questionário como uma possível área a ser fortalecida. Sugestões para pesquisas futuras, contemplar esses aspectos. 


\section{DISCUSSÃO DOS RESULTADOS}

\subsection{Caracterização e descrição das escolas pesquisadas}

O universo de pesquisa incluiu duas escolas públicas regulares urbanas de Ensino Médio, ambas localizadas no Plano Piloto de Brasília, no Distrito Federal. A primeira, denominada escola A, encontra-se a $4 \mathrm{~km}$ e a segunda, escola $\mathrm{B}$, a cerca de $8 \mathrm{~km}$ do centro da Capital Federal. Ainda que as duas estejam no Plano Piloto, observaram-se, por meio dos resultados do ENEM, duas diferenças entre elas: uma em relação ao nível socioeconômico dos alunos e outra no tocante à formação docente.

Criado pelo INEP no ano de 2014, o Indicador de Nível Socioeconômico (Inse) das Escolas tem por objetivo "situar o conjunto dos alunos atendidos por cada escola em um estrato, definido pela posse de bens domésticos, renda e contratação de serviços pela família dos alunos e pelo nível de escolaridade de seus pais" (INEP, 2014a, p. 1).

Também desenvolvido em 2014, o Indicador de adequação da formação do docente da educação básica visa medir o alinhamento da formação acadêmica dos docentes com a(s) disciplina(s) que lecionam, segundo as orientações legais (INEP, 2014b). Dessa forma, o índice é construído com base em cinco perfis de regência das disciplinas, conforme apresentado no Quadro 3:

Quadro 3: Categorias de adequação da formação dos docentes em relação à disciplina que leciona

\begin{tabular}{|c|l|}
\hline Grupo & \multicolumn{1}{|c|}{ Descrição } \\
\hline 1 & $\begin{array}{l}\text { Docentes com formação superior de licenciatura na mesma disciplina que lecionam, ou } \\
\text { bacharelado na mesma disciplina com curso de complementação pedagógica concluído. }\end{array}$ \\
\hline 2 & $\begin{array}{l}\text { Docentes com formação superior de bacharelado na disciplina correspondente, mas sem } \\
\text { licenciatura ou complementação pedagógica. }\end{array}$ \\
\hline 3 & $\begin{array}{l}\text { Docentes com licenciatura em área diferente daquela que leciona, ou com bacharelado } \\
\text { nas disciplinas da base curricular comum e complementação pedagógica concluída em } \\
\text { área diferente daquela que leciona. }\end{array}$ \\
\hline 4 & Docentes com outra formação superior não considerada nas categorias anteriores. \\
\hline 5 & Docentes que não possuem curso superior completo. \\
\hline
\end{tabular}

Fonte: INEP, $2014 b$.

Por meio dos resultados do ENEM 2013 e 2014, verificou-se que enquanto na escola A o nível socioeconômico dos alunos é alto, o Inse da escola B é médio alto, característica verificada em $60 \%$ das escolas públicas do Distrito Federal. Com isso, a pesquisa pode analisar a opinião de dois perfis de jovens. 
Em relação ao Indicador de adequação da formação docente, a escola A possuía, nos anos de 2013 e 2014, índice de quase $100 \%$, enquanto na escola B o índice era de $60 \%$, o que corresponde a um dos piores índices entre as escolas públicas regulares no DF nesse período. Desse modo, a pesquisa buscou contar com a visão de dois perfis de docentes (INEP, 2014c; INEP, 2015b). Porém, de acordo com a pesquisa de campo verificou-se que, entre os respondentes da escola $\mathrm{A}$, apenas $50 \%$ dos docentes atuam na instituição há mais de 2 anos. $\mathrm{Na}$ escola $\mathrm{B}$, dos respondentes, $60 \%$ trabalham na escola há mais de 3 anos.

Nesse sentido, com a disponibilização dos resultados do ENEM 2015 (INEP, 2016b), foi possível verificar que a rotatividade de docentes na escola A refletiu na queda significativa do Índice de Formação Docente da escola. De quase 100 em 2014, caiu para cerca de 70 o percentual de docentes com formação adequada em 2015. Em relação à escola B, a rotatividade foi favorável. Houve um aumento do índice de $60 \%$ para $70 \%$ a parcela de docentes com formação adequada.

Ainda a título de contextualização das escolas, outros indicadores constantes nos resultados do ENEM do ano de 2014 (INEP, 2015b), por unidade escolar, são: Indicador de Permanência na Escola (IPE); taxa de aprovação; taxa de reprovação e taxa de abandono.

Um fator de distinção que deve ser considerado e que interfere na qualidade da educação ofertada pela escola refere-se ao IPE. De acordo com os resultados do ENEM 2014, enquanto $40 \%$ a $60 \%$ dos alunos da escola A estudaram os três anos do Ensino Médio na escola, na escola B entre $20 \%$ e $40 \%$ dos alunos concluíram os três anos na mesma escola.

Em relação às taxas, somente o valor da taxa de reprovação foi semelhante entre as duas escolas, em torno de $20 \%$. Na escola A, a taxa de aprovação é menor que na escola B, porém, ambas em torno de $70 \%$. No tocante à taxa de abandono, enquanto na escola $\mathrm{A}$ ficou em cerca de 5\% no ano de 2014 , na escola B foi inexistente.

Isto posto, nos Quadros 4 e 5 apresenta-se o resumo dos indicadores obtidos em 2014 pelas duas escolas pesquisadas.

Quadro 4: Indicadores das escolas A e B no ano de 2014

\begin{tabular}{|c|c|c|c|c|c|c|}
\hline Escola & $\begin{array}{c}\text { Indicador de } \\
\text { Permanência } \\
\text { na Escola }\end{array}$ & $\begin{array}{c}\text { Indicador Nível } \\
\text { Socioeconômico }\end{array}$ & $\begin{array}{c}\text { Indicador de } \\
\text { Formação } \\
\text { Docente }\end{array}$ & $\begin{array}{c}\text { Taxa de } \\
\text { Aprovação }\end{array}$ & $\begin{array}{c}\text { Taxa de } \\
\text { Reprovação }\end{array}$ & $\begin{array}{c}\text { Taxa de } \\
\text { Abandono }\end{array}$ \\
\hline A & De $40 \%$ a $60 \%$ & Alto & $>90$ & cerca de 70 & cerca de 20 & $<10$ \\
\hline B & De $20 \%$ a $40 \%$ & Médio Alto & cerca de 60 & cerca de 70 & cerca de 20 & 0 \\
\hline
\end{tabular}

Fonte: INEP, 2015b. 
A título de acompanhamento, de acordo com os resultados auferidos no ENEM edição 2015, os principais índices que sofreram modificação em relação ao ano anterior foram: i) o Indicador de Formação Docente de ambas as escolas ficou em torno de 70, ou seja, houve melhora desse índice na escola B, porém, significativa piora na escola A; ii) Melhora na taxa de aprovação, em ambas subiu para cerca de 80 ; iii) taxa de reprovação ficou abaixo de 10 na escola $\mathrm{B}$ e de abandono, subiu para quase 10, na mesma escola, conforme dados apresentados no Quadro 5.

Quadro 5: Indicadores das escolas A e B no ano de 2015

\begin{tabular}{|c|c|c|c|c|c|c|}
\hline Escola & $\begin{array}{c}\text { Indicador de } \\
\text { Permanência } \\
\text { na Escola }\end{array}$ & $\begin{array}{c}\text { Indicador Nível } \\
\text { Socioeconômico }\end{array}$ & $\begin{array}{c}\text { Indicador de } \\
\text { Formação } \\
\text { Docente }\end{array}$ & $\begin{array}{c}\text { Taxa de } \\
\text { Aprovação }\end{array}$ & $\begin{array}{c}\text { Taxa de } \\
\text { Reprovação }\end{array}$ & $\begin{array}{c}\text { Taxa de } \\
\text { Abandono }\end{array}$ \\
\hline A & De $40 \%$ a $60 \%$ & Alto & cerca de 70 & cerca de 80 & cerca de 20 & $<5$ \\
\hline B & Menos de $20 \%$ & Médio Alto & cerca de 70 & cerca de 80 & $<10$ & $5<10$ \\
\hline
\end{tabular}

Fonte: INEP, 2016b.

Cabe destacar que, as Taxas de Aprovação, Reprovação e Abandono, foram apresentadas a título de contextualização das escolas e não serão analisadas em razão de extrapolar o escopo do trabalho.

\subsubsection{Perfil da Escola A}

Escola pública regular urbana de Ensino Médio, a escola A está localizada no Plano Piloto, há 4 quilômetros do centro de Brasília-DF. Área de fácil acesso por meio de transporte público e bem servida de comércio e serviços, além de prédios residenciais próximos.

De acordo com o Projeto Político Pedagógico (PPP) da Escola A, inaugurada no ano de 1981, sua constituição recebeu influência de diversas experiências educacionais locais anteriores, iniciadas na década de 1960 e fundamentadas em aspectos político-pedagógicos da Escola Nova, a qual tinha por base as teorias de John Dewey e Jean Piaget.

Segundo o PPP da escola, este foi elaborado, apreciado e aprovado de modo coletivo, contando com a participação de docentes, pais e alunos, além do Conselho Escolar.

\section{Gestão Escolar}

No tocante à gestão escolar, o PPP informa que em 2012, a direção foi indicada e posteriormente referendada pela comunidade escolar, com o pleito de um ano. Em 2013, para 
um mandato de 03 anos, ocorreram eleições aos cargos de Diretor e Vice e para os integrantes do Conselho Escolar, fato este inserido na Gestão Democrática.

Cabe salientar que a gestão democrática do ensino público está prevista na Constituição Federal (art. 206, inciso VI), na Lei de Diretrizes e Bases da Educação Nacional (arts. $3^{\circ}$, inciso VIII, e 14) e na Lei Orgânica do Distrito Federal (art. 222). Para a sua implementação local, foi promulgada a Lei $\mathrm{n}^{\mathrm{o}} 4.036 / 2007$, pela qual se estabelece a gestão compartilhada nas instituições educacionais da rede pública de ensino do Distrito Federal. A lei prevê como um de seus objetivos, assegurar a qualidade, a equidade e a responsabilidade social de todos os envolvidos (art. 2, inciso I). Para isso estabelece que a gestão seja "desempenhada pelo diretor e pelo vice-diretor, em consonância com as deliberações do Conselho Escolar" (art. $3^{\circ}$ ), cujos integrantes serão capacitados pela Secretaria de Estado de Educação, para o exercício de suas funções (parágrafo único do art. $3^{\circ}$ da Lei Distrital $\left.\mathrm{n}^{\circ} 4.036 / 2007\right)$.

Posto isso, o dirigente da escola A informou que trabalha na escola faz sete anos, destes menos de um ano atuou como supervisor pedagógico e os demais como diretor. Assim, nunca vivenciou a regência de sala nessa escola, porém, lecionou por 15 anos em outra escola. Atuou também como coordenador pedagógico e supervisor em outras escolas.

Formado em licenciatura plena em matemática e docência superior, a direção realizou curso de gestão promovido pela Secretaria de Educação do Governo do Distrito Federal (GDF) entre os anos de 2011 e 2012. Desse período pra cá não participou de cursos voltados para a área.

Segundo a direção da escola $\mathrm{A}$, há dois órgãos principais que assessoram a escola, são eles: o Conselho Escolar, que é deliberativo, e a Associação de Pais, Alunos, Auxiliares e Mestres (APAAM), que é a entidade executora. Outros meios de participação e contribuição na escola são: Representante de Turma, Grêmio Estudantil e o Conselho de Classe. Outro instrumento apontado no PPP da escola é o pré-Conselho, o qual se trata de uma "reunião de preparação para o Conselho de Classe participativo. É um espaço onde a turma, os representantes e os conselheiros irão se organizar para discutir e registrar considerações avaliativas a serem apresentadas no Conselho de Classe” (PPP escola A, 2016, p. 72).

De acordo com a entrevista (E1), a gestão da escola A é dividida da seguinte forma: a direção desempenha a gestão administrativa e financeira, além de ficar responsável pela busca e constituição das parcerias externas, enquanto a vice direção acompanha os aspectos pedagógicos da unidade escolar. 
No tocante à prática pedagógica, com intuito de promover uma educação mais qualitativa, integral do ponto de vista da formação do aluno, a escola oferece oficinas diversificadas. Entre elas: de robótica; química dos alimentos; sobre a cultura da Inglaterra; redação para o Programa de Avaliação Seriada da Universidade de Brasília (PAS/UnB) e para o ENEM; sustentabilidade; dança; yoga; política, cine arte, na qual são trabalhados filmes históricos, entre outras. Com duração de duas horas cada, por semana, são realizadas as terças e quintas-feiras. Ao todo são oferecidas 12 oficinas, tanto para os alunos da manhã como para os da tarde, dentre as quais o estudante escolhe uma para realizar no semestre, no seu turno de aula.

Segundo a direção, as oficinas são um ponto de atrito com alguns professores, alvo de muita discussão: "tem professor que aceita, tem professor que não gosta, tem professor que adora" (Direção Escola A- E1). O intuito é ampliar a formação do estudante.

Com duração de duas horas por semana, as oficinas são ministradas pelos próprios docentes da escola ou por meio de parcerias externas. Como exemplos, a oficina de dança é promovida pelo Instituto Federal Brasília, já robótica é ministrada por um ex-aluno da escola que está cursando computação na UnB.

Dessa forma, as oficinas visam o exercício prático da área, por exemplo, "na oficina de sustentabilidade, os alunos vão pegar na massa mesmo, vão lá cuidar lá da horta, vão cuidar da árvore, vão cuidar do jardim da área florestal, vão cuidar lá de uma hortinha" (Direção Escola A, E1).

Entre as parcerias, a escola possui, também, com a agência de intercâmbio AFS. De acordo com o sítio eletrônico da agência, trata-se de "uma organização internacional, voluntária, não governamental e sem fins lucrativos, comprometida em oferecer oportunidades de aprendizagem intercultural por meio de programas de intercâmbio". Por meio dessa parceria a escola recebe cerca de três a quatro alunos estrangeiros por semestre. Segundo a direção, vêm alunos de diversos países, como Argentina Alemanha, Sérvia, Índia, China, Austrália. A duração do intercâmbio varia de quinze dias a um ano.

Com a UnB, a escola A constitui parcerias com alguns departamentos, que encaminham estudantes para fazer estágio, monitoria, nas áreas de Línguas, Matemática, Química, por meio do Programa Institucional de Bolsas de Iniciação à Docência (PIBID) do MEC; também já realizou parceria com o Centro de Desenvolvimento Tecnológico, e com o Instituto de Permacultura IPOEMA. Patrocinada pela Petrobrás, o instituto construiu a fossa ecológica e o tanque de captação de água da chuva. Todo esse processo foi acompanhado pelos alunos da oficina de sustentabilidade. A parceria finalizou no ano de 2015. 
Para melhor desenvolvimento da prática pedagógica, a escola A implementou sala ambiente para cada disciplina. Com isso, os estudantes mudam de sala a cada duas aulas seguidas de 50 minutos cada. Entre essas aulas duplas é dado um intervalo de 15 minutos para os alunos mudarem de sala e se organizarem. Ao todo são três aulas duplas e dois intervalos de 15 minutos cada. A merenda escolar é oferecida no segundo intervalo (10h45 às $11 \mathrm{~h})$. Ao todo são ministradas três disciplinas por dia. No contra turno, são oferecidas atividades esporádicas, como a monitoria de algumas matérias.

Em relação à colocação no ENEM, de acordo com a direção, a escola $\mathrm{A}$ não trabalha com intuito de atingir índices de desempenho em relação ao número de alunos que ingressam na UnB. Por isso, não separa os melhores alunos em uma sala. Segundo o dirigente, isso geraria o seguinte problema: "E aí o professor gosta de trabalhar nessa turma, então ele se empolga com essa turma, e os outros como é que ficam? A gente não trabalha assim não" (Direção Escola A - E1).

Com vistas ao ENEM, a escola A promove, além de algumas oficinas com esse foco, a feira literária. Nela os alunos do segundo e do terceiro anos realizam teatro referente aos livros cobrados no ENEM e no PAS da UnB. Dessa forma, a escola trabalha os autores junto aos alunos. Com isso, de acordo com a direção, os alunos:

vão ter que ler o livro para poder fazer a interpretação deles aqui, a princípio, é claro que não são todos que fazem, mas aqueles que fazem [...] tem um conhecimento do livro, do que acontece no livro, então eles fazem teatro do livro dentro da sala [...], então a gente sai visitando as salas (Direção Escola A - E1).

Em relação à formação promovida pela escola, segundo a direção:

Se você me perguntar, a sua escola é boa? [...] é boa, eu acho que é uma escola boa, prepara bem o aluno para o que vai vir, para ele ir para o mercado de trabalho, para ele ir para uma faculdade, para ele fazer as coisas que ele tem que fazer, eu acho que a gente prepara ele em cima disso (Direção Escola A - E1).

Em relação aos desafios vivenciados na condução da escola, a direção apontou a

gestão de pessoas como um ponto crucial. E destacou a importância do coordenador pedagógico na mediação dos interesses. Segundo a direção:

Coordenação pedagógica, os professores [elegem]. Há um conflito aí, o coordenador pedagógico ele trabalha com a gente também, com a direção, e ao mesmo tempo com os professores, então há um certo conflito nesse processo, a gente tem que ter as manhas e artimanhas para poder atender essa demanda [melhorar a qualidade], porque eles são cobrados pelos professores: "eu elegi você", e não foi escolhido por mim, direção. [...] Mas ao mesmo tempo a gente tem que falar a mesma coisa, mesma linguagem, porque a gente afina o projeto pedagógico da escola. Se eu tiver um processo de embate direto com a coordenação eu vou sair bem prejudicado.

$[\ldots]$

Por exemplo, a gente quer fazer uma feira de ciências, leva o diretor para os professores e os professores fecham com a coordenação que não querem a feira de ciências. Há um conflito aí, e o conflito aí bancado até por uma coordenação que também fala que não quer. Aí tem conversa, aí tem que conversar, de alguma forma 
as partes tem que sair convencidas de que tem que ter ou não tem que ter... (Direção Escola A - E1).

A Feira Literária que, segundo a direção, “está no projeto político pedagógico. É um debate intenso de convencimento". Com isso é possível constatar a complexidade que é gerir uma escola.

Outro aspecto apontado pela direção se refere à ingerência ou baixa autonomia dada pela Secretaria de Educação do GDF no quesito de gestão de pessoas. Para a direção escolar, seria necessário que a escola tivesse três coordenadores pedagógicos ao invés de dois. E dois supervisores educacionais, ao invés de um. Segundo a direção o supervisor é uma pessoa que ocupa cargo comissionado, escolhida pela direção e que faz a ponte entre direção, professores e alunos. Conforme relata:

\begin{abstract}
antigamente dois supervisores na escola [um administrativo e um pedagógico] [...] eu preciso de alguém no administrativo com ela, então é uma forma de você melhorar as condições da escola, ensino de qualidade. O supervisor que deveria, o que abre o turno, é o que mantém os alunos, vendo os alunos, olhando os alunos, vendo a necessidade dos alunos e dos professores na sala de aula (Direção Escola A $-\mathrm{E} 1)$.
\end{abstract}

Dessa forma, com vistas a proporcionar uma educação de melhor qualidade, a direção entende ser importante o aumento de profissionais no quadro da escola, tanto supervisor quanto coordenador.

Questionada sobre o melhor desempenho de muitas escolas particulares no ENEM, a direção escolar explicou que as unidades particulares focam o ensino nas avaliações externas, como ENEM e vestibulares em geral. Por isso, não se debruçam em temas e questões de formação integral do indivíduo. Motivo pelo qual a ênfase dada por essas instituições particulares na avaliação do aluno é a prova.

Assim, para o dirigente, a principal diferença entre escolas públicas e particulares está no "método de ensino. Eles são voltados para a prova, prova, prova. A pública não se preocupa só com a prova, a gente se preocupa com outras coisas que cercam o aluno, que é fundamental" (Direção Escola A, E1).

Por isso, na seara da avaliação do aluno, a direção esclarece que a mesma se dá da seguinte forma na escola A: dos dez pontos previstos, cinco provém de duas provas formais. Uma denominada "provão", multidisciplinar, tipo ENEM, vale 3 pontos, a outra, discursiva de cada disciplina, vale 2 pontos. Os outros cinco pontos são obtidos ao longo do processo de aprendizado, para isso avalia-se o comportamento, a frequência, o trabalho entregue e a participação do aluno em oficinas, feiras, o saber trabalhar em equipe, como a gincana promovida na escola. 
A gincana funciona da seguinte maneira: são formados cinco grupos com os alunos do $1^{\circ}, 2^{\circ}$ e $3^{\circ}$ anos e a cada grupo é demandada uma tarefa diferente a ser apresentada no final. Com isso, além dos estudantes do matutino serem integrados aos do vespertino, os alunos são desafiados a trabalhar em equipe, o que envolve saber se relacionar, desenvolver poder de negociação, escolha de liderança, aprender a lidar com contrariedades e ter humildade para aprender com o outro. Com isso, segundo a direção, visa-se ampliar e transcender o saber da disciplina em si e ir além da prova do ENEM. Isso vai ao encontro do desenvolvimento de habilidades socioemocionais, tais como nos ensina Abed (2014), saber inserir-se no grupo, saber trabalhar em equipe, saber expressar-se com clareza, respeitar, ser colaborativo, cooperativo e saber postergar seus desejos em prol dos objetivos do grupo.

Outro aspecto apontado pela direção se refere às principais disciplinas que reprovam, quais sejam: matemática, física e química. Isso, apesar de haver a possibilidade de o aluno ficar com dependência em duas disciplinas. Se ficar em três é reprovado.

\section{Financiamento}

De acordo com o PPP da escola A, a APAAM (Associação de Pais, Alunos, Auxiliares e Mestres), juntamente com a direção da escola e toda a comunidade escolar, define as prioridades e administra financeiramente os recursos.

Do Governo Distrital, a escola A recebe recursos por meio do Programa de Descentralização Administrativa e Financeira (PDAF). Como fonte de financiamento do Governo Federal, a escola A obtém verbas por meio do Programa Dinheiro Direto na Escola (PDDE) e do Programa Ensino Médio Inovador (ProEMI), ambos do MEC, operacionalizados pelo Fundo Nacional de Desenvolvimento da Educação (FNDE).

Em relação os recursos recebidos pela escola A no período de 2012 a 2016, cumpre observar que houve divergência entre os dados fornecidos pelas três fontes, a saber: escola pesquisada, GDF e FNDE. Porém, cabe esclarecer que essa questão não foi aprofundada em razão de não ser o foco da pesquisa.

No tocante aos repasses realizados pelo Governo Distrital, optou-se por apresentar os dados fornecidos pela própria escola, uma vez que se obteve a informação, de modo 
informal $^{1}$, de que os valores constantes nos sistemas eletrônicos do GDF são aqueles empenhados pelo governo e não necessariamente foram transferidos às escolas nesse período.

Em relação aos repasses federais, utilizaram-se os dados obtidos no sítio eletrônico do FNDE, tendo em vista tratar-se dos recursos financeiros repassados pela autarquia à unidade escolar. No Quadro 6 apresentam-se os valores recebidos pela escola A no período de 2012 a 2016, segundo essas fontes.

Quadro 6: Recursos financeiros recebidos pela Escola A no período de 2012 a 2016.

\begin{tabular}{|c|c|c|c|c|c|c|}
\hline \multirow{2}{*}{ Escola A } & Verba & $\begin{array}{c}2012 \\
(\mathrm{R} \$)\end{array}$ & $\begin{array}{c}2013 \\
(\mathrm{R} \$)\end{array}$ & $\begin{array}{c}2014 \\
(\mathrm{R} \$)\end{array}$ & $\begin{array}{c}2015 \\
(\mathrm{R} \$)\end{array}$ & $\begin{array}{c}2016 \text { (até } \\
\text { novembro) } \\
(\mathrm{R} \$)\end{array}$ \\
\hline \multirow{2}{*}{ PDAF } & CAPITAL & $59.200,00$ & $99.600,00$ & $47.000,00$ & $76.300,00$ & $38.200,00$ \\
\cline { 2 - 7 } & CUSTEIO & $48.600,00$ & $2.900,00$ & 0,00 & 0,00 & 0,00 \\
\hline PDDE & GLOBAL & $5.300,00$ & $14.500,00$ & $7.300,00$ & 0,00 & 0,00 \\
\hline PROEMI & GLOBAL & $50.000,00$ & $50.000,00$ & $18.000,00$ & $7.500,00$ & 0,00 \\
\hline TOTAL & TOTAL & $163.100,00$ & $167.000,00$ & $72.300,00$ & $83.800,00$ & $38.200,00$ \\
\hline
\end{tabular}

Fonte: Escola A e FNDE.

Assim, do Governo do Distrito Federal, de acordo com dados fornecidos pela direção, a escola A recebeu em 2012, por meio do PDAF, o montante de R \$107.800,00, sendo $\mathrm{R} \$ 48.600,00$ para gastos com custeio e $\mathrm{R} \$ 59.200,00$ para despesas de capital. No ano de 2013, o valor recebido foi de $\mathrm{R} \$ 102.500,00$, destes, $\mathrm{R} \$ 99.600,00$ para despesas de capital. Já nos anos subsequentes, 2014 e 2015, o GDF repassou os valores de R\$47.000,00 e $\mathrm{R} \$ 76.300,00$, respectivamente, ambos para despesas de capital. A título de base comparativa, em 2016 a escola havia recebido, até o mês de novembro, R\$38.200,00 do GDF.

Em relação aos recursos provenientes do Governo Federal, de acordo com o FNDE, a escola A recebeu, por meio do ProEMI, R\$50.000,00 no ano de 2012 e o mesmo valor em 2013; R\$18.000,00 em 2014 e R\$7.500,00 no ano de 2015. Em relação ao PDDE, segundo a autarquia, foram repassados nos anos de 2012, 2013 e 2014, respectivamente, R\$5.300,00, R\$14.500,00 e R\$7.300,00. Em 2015 e 2016, não há indicação de repasse por meio desse programa para a escola A.

Dessa forma, pode-se observar que houve queda significativa no repasse de recursos tanto pelo Governo Federal quanto Distrital nesse período. Enquanto nos anos de

\footnotetext{
${ }^{1}$ Informação prestada por servidor da Secretaria de Educação do Governo do Distrito Federal por telefone.
} 
2012 e 2013 a escola recebeu, em média, R\$165.000,00. Nos anos de 2014 e 2015 esse valor caiu, respectivamente, para $\mathrm{R} \$ 72.300,00, \mathrm{R} \$ 83.800,00$. E, a título de acompanhamento, em 2016 a escola B recebeu recursos apenas do GDF no valor de $\mathrm{R} \$ 38.200,00$.

Segundo a direção escolar, a escola A não conta com fonte adicional. A APAAM não contribui financeiramente com a escola, apesar dos esforços empreendidos nesse sentido.

\section{Missão e Objetivo Geral da Escola A}

Em relação à missão, de acordo com o PPP:

A escola e seus agentes têm como missão a educação. Esta é vista como atividade mediadora capaz de viabilizar a sistematização do saber escolar por meio da relação entre os sujeitos escolares e o conhecimento acumulado pelas ciências, pela filosofia, pelas artes e pelo senso comum. Aliada ao conhecimento acrescenta-se a apropriação de valores, ambos necessários à formação cidadã. Tonar-se um centro de excelência em educação para vida (PPP Escola A, 2016, p. 44).

Nesse sentido, cabe salientar que a escola disponibiliza uma sala para o Grêmio Estudantil, o que possibilita o empoderamento do jovem e lhe dá condições de se reunir, trocar ideias e experiências e organizar suas ações. Isso propicia o desenvolvimento de "competências e habilidades capazes de torná-lo sujeito consciente, autônomo, sensível, atuante, responsável, crítico e democrático", objetivo geral da escola, além de ampliar e aprofundar o conhecimento adquirido no Ensino Fundamental (PPP Escola A, 2016, p. 45).

Uma preocupação apontada no PPP é no tocante à humanização do espaço escolar. De acordo com o documento, "A estrutura física da escola e a sua organização político-pedagógica propicia e materializa-se, na práxis, uma vivência democrática, de liberdade, responsabilidade e autonomia" (PPP Escola A, 2016, p. 13).

Essa prática foi possível verificar durante a pesquisa de campo, quando jovens pintavam na escada de entrada da escola frases de combate à homofobia e à discriminação de modo geral. Como apontou a direção escolar:

a gente trabalha com instrumentalidade, a gente trabalha com diversidade [...] religiosa, cultural, sexual, por exemplo, quando você passar você vai ver a escadinha ali, os meninos mexendo [...] essa questão de homofobia, entendeu, tudo isso eles trabalham e a escola dá a maior liberdade para eles em cima desse processo, a gente cobra só responsabilidade em cima desse processo também (Direção Escola A - E1).

Isso proporciona ao estudante a percepção de que a escola é um espaço realmente seu, no qual ele pode sim ser um agente de mudança. Além de possibilitar um sentimento de pertencimento, de respeito mútuo, de confiança e de responsabilidade, bastante favorável em um ambiente de aprendizagem de jovens. 


\section{Infraestrutura Física da Escola A}

No tocante à infraestrutura física, além da sala para o Grêmio Estudantil, a escola A possui 14 salas de aula ambientadas, uma sala de leitura/biblioteca, um laboratório de informática com 27 máquinas e impressora, sala de múltiplas funções, cantina, refeitório, sala de coordenação, sala dos professores, sala de orientação educacional, rádio, sala de recursos, sala da direção, secretaria, laboratórios (química e biologia), sala dos servidores, banheiro dos professores, dois banheiros de alunos, sala de educação física, vestiário, uma quadra coberta e um piso descoberto usado como quadra de vôlei (PPP da Escola A, 2016).

As salas de aula ambientadas são salas temáticas (como exemplos, sala de física, sala de geografia), o que possibilita um melhor aproveitamento do espaço, do horário e de uso de recursos pedagógicos pelo professor. Isso requer dos alunos a troca de ambiente a cada duas aulas seguidas, outra característica pedagógica estabelecida na escola. Ao todo são 6 aulas por dia, distribuídas em três disciplinas. Intercalando cada aula dupla de $1 \mathrm{~h} 30$, são realizados intervalos de 15 minutos. Essa mudança faz com que o aluno se movimente, desperte, o que pode melhorar a concentração e o aprendizado.

Já a sala de recursos é destinada à alunos com necessidade de acompanhamento especial, tais como déficit de atenção e deficiência intelectual. Na escola, segundo o PPP, atualmente está sem uso, pois não dispõem de profissionais para sua utilização.

Em relação à cantina, de acordo com a entrevista, optou-se por encerrar o seu uso em favor de uma alimentação mais equilibrada concedida pela merenda escolar. Além de priorizarem uma refeição completa no segundo intervalo, disponibilizam almoço aos estudantes quando a escola promove alguma atividade extraordinária no contra turno (por exemplo, saída ao teatro).

Ainda em relação ao ambiente físico, uma demanda apresentada pela direção, pelos docentes e relatado por alunos no momento da aplicação do questionário, e que, segundo todos, influencia na qualidade da educação ofertada, é a construção de um auditório. Atividades mais amplas, que demandem mais de duas turmas (80 pessoas), são restringidas em função dessa carência.

\section{Coordenação Pedagógica da Escola A}

O cargo de coordenador pedagógico é regulado, atualmente, pela Portaria da Secretaria de Estado de Educação, Esporte e Lazer do DF n²7/2016. Entre os requisitos para o exercício no cargo estão: ser professor de Educação Básica do DF; ser eleito pelos professores; ter, no mínimo, três anos de efetivo exercício em sala de aula; atender ao Projeto 
Político Pedagógico da unidade escolar e ter habilitação compatível com a etapa de atuação, no caso, Ensino Médio (DISTRITO FEDERAL, 2016, art. 34, incisos).

A escola A possui dois coordenadores pedagógicos. Eleitos pelos docentes para uma gestão de um ano podem ser reeleitos por quantas vezes desejarem. Na pesquisa, dois responderam ao questionário aplicado, um trabalha em período integral na escola pesquisada e o outro somente no turno vespertino.

No tocante ao perfil dos coordenadores, é relevante observar que ambos lecionaram em sala de aula mais de 10 anos, o que é bastante positivo no sentido de que conhecem a realidade e os desafios da prática.

$\mathrm{Na}$ função de coordenador pedagógico, um atua há cerca de 2 a 3anos, mas há menos de 2 anos na escola $\mathrm{A}$; o outro, há mais de 3 anos nessa função, porém, na escola $\mathrm{A}$, menos de um ano. Quanto à formação acadêmica, ambos possuem especialização. Em relação ao total de capacitações relacionadas à educação, nos últimos 2 (dois) anos, 1 realizou uma, enquanto o segundo quatro ou mais. No Quadro 7 apresenta-se um resumo do exposto.

Quadro 7: Perfil da Coordenação Pedagógica da Escola A

\begin{tabular}{|c|c|c|c|c|c|c|}
\hline $\begin{array}{l}\text { Coordenador } \\
\text { Pedagógico } \\
\text { Escola A }\end{array}$ & $\begin{array}{l}\text { Atua } \\
\text { nessa } \\
\text { função }\end{array}$ & $\begin{array}{c}\text { Nessa } \\
\text { função na } \\
\text { Escola A }\end{array}$ & $\begin{array}{l}\text { Experiência } \\
\text { em sala de } \\
\text { aula }\end{array}$ & $\begin{array}{l}\text { Lecionou na } \\
\text { Escola A }\end{array}$ & $\begin{array}{l}\text { Formação } \\
\text { acadêmica }\end{array}$ & $\begin{array}{c}\mathrm{N}^{\mathrm{o}} \text { de } \\
\text { capacitações } \\
\text { nos últimos } 2 \\
\text { anos }\end{array}$ \\
\hline 1 & $\begin{array}{l}2 \text { a } 3 \\
\text { anos }\end{array}$ & $\begin{array}{c}\text { de } 1 \text { a } 2 \\
\text { anos }\end{array}$ & $\begin{array}{c}\text { mais de } 10 \\
\text { anos }\end{array}$ & $\begin{array}{c}\text { menos de } 1 \\
\text { ano }\end{array}$ & Especialização & 1 \\
\hline 2 & $\begin{array}{c}\text { mais de } 3 \\
\text { anos }\end{array}$ & $\begin{array}{c}\text { menos de } \\
1 \text { ano }\end{array}$ & $\begin{array}{c}\text { mais de } 10 \\
\text { anos }\end{array}$ & $\begin{array}{c}\text { de } 1 \text { a } 3 \\
\text { anos }\end{array}$ & Especialização & 4 ou mais \\
\hline
\end{tabular}

Diante desse contexto, verifica-se que ambos não colaboraram, nessa função de coordenador pedagógico, para o sucesso da escola A no ENEM no período analisado de 2012 a 2014.

\section{Público Docente da Escola A (Perfil)}

No tocante ao público docente da escola $\mathrm{A}$, de um total de 30 profissionais que atuam em regência de classe, responderam ao questionário 13 docentes, sendo seis do período matutino ( $2^{\circ}$ e $3^{\circ}$ anos) e sete do vespertino ( $1^{\circ}$ e $2^{\circ}$ anos).

No DF, segundo a Portaria $\mathrm{n}^{\circ} 27 / 2016$ da Secretaria de Estado de Educação, Esporte e Lazer, a carga horária de trabalho dos professores do Ensino Médio que atuam em regência de classe, de modo geral, é distribuída da seguinte forma: para aqueles que trabalham 40 horas semanais, 25 horas são destinadas ao exercício em sala de aula e 15 horas à 
coordenação pedagógica, das quais $6 \mathrm{~h}$ podem ser utilizadas para formação continuada. Para os docentes que trabalham 20 horas semanais, 12 horas em exercício em sala de aula e 8 horas em coordenação pedagógica (DISTRITO FEDERAL, 2016, arts. 4, 26 e 27).

É importante destacar que parte da carga horária destinada à coordenação pedagógica pode ser utilizada para formação continuada fora do ambiente da unidade escolar, o que demonstra, por parte do poder público, incentivo para que os docentes se aperfeiçoem permanentemente dentro do horário de trabalho semanal. Cumpre, ainda, salientar que a duração das aulas é de cinquenta minutos, salvo as duas últimas aulas do turno noturno, que possuem duração de quarenta e cinco minutos. A seguir apresentamos o perfil do público docente que respondeu à pesquisa.

No tocante à experiência, $77 \%$ dos respondentes informaram possuir mais de 10 anos de atuação na área de docência; $15 \%$, entre 5 e 10 anos e $8 \%$, até 5 anos de experiência, conforme demonstrado no Quadro 8.

Quadro 8: Docentes da escola A, anos de experiência na área

\begin{tabular}{|c|c|c|}
\hline 0 a 5 anos & 5 a 10 anos & acima de 10 anos \\
\hline $8 \%$ & $15 \%$ & $77 \%$ \\
\hline
\end{tabular}

Em relação aos anos de atuação na escola A, conforme Quadro 9, verificou-se que, dos pesquisados, cerca de $70 \%$ lecionam na escola $\mathrm{A}$ há menos de três anos, o que tende a dificultar o aperfeiçoamento da implementação do Projeto Político Pedagógico da escola e a maturação da proposta pedagógica e, consequentemente, prejudica a melhoria da qualidade do ensino ofertado.

Quadro 9: Anos de docência na escola A

\begin{tabular}{|c|c|c|c|}
\hline menos de 1 ano & de 1 a 2 anos & de 2 a 3 anos & acima de 3 anos \\
\hline $38 \%$ & $8 \%$ & $23 \%$ & $31 \%$ \\
\hline
\end{tabular}

Dos 13 respondentes, 6 lecionam na área de Linguagens (Língua Portuguesa; Inglês/Espanhol; Artes, Educação Física; Tecnologias da Informação e Comunicação); 3 são professores na área de Ciências da Natureza (Biologia; Física, Química e Matemática) e 4 de Ciências Humanas (História; Geografia; Filosofia e Sociologia), conforme apresentado no Quadro 10.

Quadro 10: Área de atuação dos professores que participaram da pesquisa na escola A

\begin{tabular}{|c|c|c|}
\hline $\begin{array}{c}\text { Linguagens: Língua Portuguesa; } \\
\text { Inglês/Espanhol; Artes, Educação } \\
\text { Física; Tecnologias da } \\
\text { Informação e Comunicação }\end{array}$ & $\begin{array}{c}\text { Ciências da Natureza: } \\
\text { Biologia; Física, Química e } \\
\text { Matemática }\end{array}$ & $\begin{array}{c}\text { Ciências Humanas: História; } \\
\text { Geografia; Filosofia e } \\
\text { Sociologia }\end{array}$ \\
\hline $46 \%$ & $23 \%$ & $31 \%$ \\
\hline
\end{tabular}


No tocante à formação acadêmica, $100 \%$ dos docentes da escola A tem formação em nível superior e licenciatura. Cerca de 70\% concluíram ou cursam pós-graduação: 39\% em nível de especialização; $15 \%$, mestrado e 15\%, doutorado. Desses, somente um informou que o mestrado foi em área diversa da qual leciona, todos os demais se aperfeiçoaram na disciplina que ministram.

Quadro 11: Formação acadêmica dos docentes da escola A participantes da pesquisa (grau concluído ou em conclusão)

\begin{tabular}{|c|c|c|c|}
\hline Graduação & Especialização & Mestrado & Doutorado \\
\hline $31 \%$ & $39 \%$ & $15 \%$ & $15 \%$ \\
\hline
\end{tabular}

Esses dados demonstram que a escola possui de fato capital humano qualificado em termos de formação acadêmica. Apesar disso, entre os anos de 2014 e 2015 houve queda significativa no Indicador de Adequação da Formação Docente. Nos anos de 2013 e 2014, a escola A possuía um índice acima de 90\%, (INEP, 2014c; INEP, 2015b). Isso indica que quase $100 \%$ dos professores possuíam "formação superior de licenciatura na mesma disciplina que lecionam, ou bacharelado na mesma disciplina com curso de complementação pedagógica concluído" (INEP, 2014b, p. 5).

Em 2014, a equipe de professores estava composta da seguinte forma: 27 docentes classificados em grau 1 (todas as disciplinas); 1 docente, grau 2 (Sociologia) e 1 professor grau 3 (Sociologia). Cabe observar que em 2014 a escola contava com a colaboração de três docentes de Sociologia. Conforme demonstrado no Quadro 12.

Quadro 12: Composição do Índice de Adequação da Formação Docente da Escola A no ano de 2014

\begin{tabular}{|c|c|l|}
\hline Grau & Total de Docentes & \multicolumn{1}{c|}{ Disciplinas } \\
\hline 1 & 27 & Todas (inclusive Sociologia) \\
\hline 2 & 1 & Sociologia \\
\hline 3 & 1 & Sociologia \\
\hline
\end{tabular}

Fonte: INEP, 2015a.

Apesar do alto índice obtido pela escola A nos anos 2013 e 2014, em 2015 caiu para 70. De acordo com dados obtidos junto ao INEP (INEP, 2016a), foi possível verificar que a queda foi em razão da rotatividade de profissionais, consolidando o quadro da seguinte forma em 2015: um docente classificado em grau 5 (Filosofia); seis professores, em grau 3 (Língua Portuguesa, dois de Língua Estrangeira, Filosofia, Química e Educação Física); um 
profissional, grau 2 (Sociologia) e 22 docentes em grau 1 (de todas as disciplinas, exceto Filosofia), conforme Quadro 13.

Quadro 13: Composição do Índice de Adequação da Formação Docente da Escola A no ano de 2015

\begin{tabular}{|c|c|l|}
\hline Grau & Total de Docentes & \multicolumn{1}{c|}{ Disciplinas } \\
\hline 1 & 22 & Todas, exceto Filosofia \\
\hline 2 & 1 & Sociologia \\
\hline 3 & 6 & $\begin{array}{l}\text { Língua Portuguesa, dois de Língua Estrangeira, Filosofia, } \\
\text { Química e Educação Física }\end{array}$ \\
\hline 5 & 1 & Filosofia \\
\hline
\end{tabular}

Fonte: INEP, 2016a.

De acordo com a direção escolar, a rotatividade de professores "é muito grande, por exemplo, desde que eu entrei aqui devem ter poucos professores que estão aqui antes de mim, eu vim para cá em 2010, agora já tem poucos, por que, vai aposentando, vai saindo, o professor ele vai migrando de escola em escola" (Direção Escola A -E1), geralmente para mais próximo de sua casa, explica.

Cabe observar que a escola não possui uma estratégia específica para recepção dos novos docentes, segundo a direção o novo docente "conhece a estrutura da escola, [...] começa a participar dos eventos da escola, das reuniões, ele vai tomando pé como é que a gente procede" (Direção Escola A-E1).

Em relação às capacitações voltadas à docência, cerca de $80 \%$ dos docentes da escola A realizou pelo menos uma capacitação anual, o que permite perceber que haja um certo grau de renovação de ideias e troca de experiências na área. Na pesquisa não foi possível avaliar se esse número é baixo ou não, tendo em vista não se saber a carga horária dessas capacitações. Podem se tratar de cursos de especialização, mestrado ou doutorado ou mesmo de cursos com carga menor, oferecidos pelo Escola de Aperfeiçoamento dos Profissionais de Educação (EAPE) do GDF ou outras instituições.

Quadro 14: Número de capacitações realizadas nos últimos 2 (dois) anos pelos docentes da escola A

\begin{tabular}{|c|c|c|c|c|}
\hline 0 & 1 & 2 & 3 & 4 ou mais \\
\hline $15 \%$ & $8 \%$ & $31 \%$ & $23 \%$ & $23 \%$ \\
\hline
\end{tabular}

Cabe lembrar que os docentes do Distrito Federal, conforme mencionado anteriormente, possuem liberação de parte da carga horária semanal para formação 
continuada, o que é um incentivo, por parte do governo, para a melhoria da qualidade da educação ofertada.

Para isso, os docentes são incentivados a participar dos cursos oferecidos pela EAPE do GDF. Em pesquisa ao sítio eletrônico da EAPE, verificou-se que, só em 2016, estão sendo oferecidos 55 cursos de extensão, destes 20 possuem carga horária de 180 horas.

\section{Perfil do Público Discente da Escola A}

No tocante ao público discente, segundo levantamento realizado pela direção da escola, no ano de 2014 cerca de 65\% dos alunos residiam no Plano Piloto; 30\% nas regiões administrativas do DF (Taguatinga, Samambaia, Riacho Fundo, Recanto das Emas, Sobradinho e Planaltina), e até 5\% moravam em Goiás, em cidades como Águas Lindas, Valparaíso e Formosa, distantes entre 45 e 75 quilômetros da escola. Outra informação relatada é que muitos pais ou responsáveis trabalham próximo à escola ou, pelo menos, no Plano Piloto, motivo pelo qual se facilita, de alguma forma, o acesso do (a) jovem à escola A. Cabe observar que, de acordo com a direção, não é percebida diferença de rendimento escolar entre os alunos do Plano e os alunos do entorno.

Segundo dados da Secretaria de Educação do Distrito Federal, a escola possuía, nos anos de 2012 a 2015, uma média 700 a 800 alunos matriculados.

No período analisado, o $1^{\circ}$ ano concentrou-se no turno vespertino, já o $2^{\circ}$ e o $3^{\circ}$ anos, pela manhã. A média de alunos variou entre 30 e 36 alunos por sala de aula no $1^{\circ}$ ano, e entre 36 e 40 alunos no $2^{\circ}$ e $3^{\circ}$ anos, conforme demonstrado no Quadro 15:

Quadro 15: Escola A: turmas, alunos por turma, série e turno, no período de 2012 a 2015.

\begin{tabular}{|c|c|c|c|c|c|c|c|}
\hline \multicolumn{4}{|c|}{ Ano 2012} & \multicolumn{4}{|c|}{ Ano 2013} \\
\hline Série & $\begin{array}{l}\mathrm{N}^{\circ} \text { de } \\
\text { turmas }\end{array}$ & $\begin{array}{c}\text { Média de } \\
\text { alunos/turma }\end{array}$ & Período & Série & $\begin{array}{l}\mathrm{N}^{\circ} \text { de } \\
\text { turmas }\end{array}$ & $\begin{array}{c}\text { Média de } \\
\text { alunos/turma }\end{array}$ & Período \\
\hline $1^{\circ}$ ano & 10 & 30 & Tarde & $1^{\circ}$ ano & 10 & 34 & Tarde \\
\hline $2^{\circ}$ ano & 5 & 38 & Manhã & $2^{\circ}$ ano & 5 & 36 & Manhã \\
\hline $3^{\circ}$ ano & 5 & 38 & Manhã & $3^{\circ}$ ano & 5 & 37 & Manhã \\
\hline \multicolumn{4}{|c|}{ Ano 2014} & \multicolumn{4}{|c|}{ Ano 2015} \\
\hline Série & $\begin{array}{l}\mathrm{N}^{0} \text { de } \\
\text { turmas }\end{array}$ & $\begin{array}{c}\text { Média de } \\
\text { alunos/turma }\end{array}$ & Período & Série & $\begin{array}{l}\mathrm{N}^{\circ} \text { de } \\
\text { turmas }\end{array}$ & $\begin{array}{c}\text { Média de } \\
\text { alunos/turma }\end{array}$ & Período \\
\hline $1^{\circ}$ ano & 10 & 34 & Tarde & $1^{\circ}$ ano & 10 & 36 & Tarde \\
\hline $2^{\circ}$ ano & 7 & 40 & Manhã & $2^{\circ}$ ano & 6 & 39 & Manhã \\
\hline $3^{\circ}$ ano & 5 & 40 & Manhã & $3^{\circ}$ ano & 6 & 39 & Manhã \\
\hline
\end{tabular}

Cabe observar que há o Índice Defasagem Idade/Série, disponibilizado apenas a partir de 2015 . No $1^{\circ}$ ano esse índice ficou em $30 \%$; no $2^{\circ}$ ano, em $28 \%$ e no $3^{\circ}$ ano, em $19 \%$. 
Como pode-se verificar, há menos alunos defasados no $3^{\circ}$ ano do que no $1^{\circ}$ e $2^{\circ}$ anos na escola A.

Segundo a direção escolar, a concentração do $1^{\circ}$ ano no período da tarde foi uma estratégia implantada para adaptação dos novos alunos às regras e ao modo de funcionamento da escola (uma vez que não há nível fundamental na escola e todos os alunos são oriundos de outras realidades escolares). Além da adaptação, outro motivo exposto é a maior dispersão da atenção e o diferente grau de maturidade da faixa etária do $1^{\circ}$ ano: "Eles passam por um processo de amadurecimento no primeiro ano, aí quando vai para o segundo ano e vai para de manhã eles já estão com outra cabeça, eles já estão vendo o pessoal do terceiro ano já disposto a outra coisa" (Direção Escola A, E1).

O público da manhã, por sua vez melhor adaptado à escola, segundo a direção possui participação mais ativa e autônoma. Ademais, busca-se, propiciar aos alunos do $2^{\circ}$ ano o contato com o público do $3^{\circ}$ ano com maior maturidade e foco noturno ENEM e no PAS.

De acordo com resultados do ENEM (INEP, 2014c; INEP, 2015b), o nível socioeconômico da escola A elevou-se de "médio alto" para "alto" entre os anos de 2013 e 2014, o que significa que houve elevação do padrão de vida de seu público discente nesse período. Segundo a Nota Técnica do INEP, a passagem desse nível para o outro indica que ocorreu não só aumento no grau de instrução dos pais ou responsáveis (de modo geral 48\% possuem nível fundamental e $29 \%$, nível médio), como também o consumo e a renda familiar aumentou, estando, em média, entre 1,5 e 7 salários mínimos (INEP, 2014a).

Diante disso, visualizam-se duas razões possíveis para esse aumento no nível socioeconômico. Ou está havendo melhora efetiva na formação e na renda das famílias dos discentes ou está ocorrendo mudança efetiva do público dessa escola, isto é, filhos de famílias com grau de instrução e com renda familiar maior estão procurando a escola e aí seria necessário um aprofundamento futuro da pesquisa para saber se isso é real. E se for, se isso está ocorrendo, nesse caso em particular, como uma forma de se enquadrar nas cotas para quem estudou todo o Ensino Médio em escolas públicas. Isso porque a Lei nº 12.711/2012 (BRASIL, 2012a), conhecida como Lei de Cotas, sancionada em 2012, "garante a reserva de $50 \%$ das matrículas por curso e turno nas 59 universidades federais e 38 institutos federais de educação, ciência e tecnologia a alunos oriundos integralmente do Ensino Médio público" (BRASIL, 2012b). 


\section{Perfil do Público Discente da Escola A que participou da pesquisa}

Na pesquisa realizada na escola A, de um total de 827 alunos do Ensino Médio regular em 2016, responderam ao questionário aplicado 339 estudantes.

Como a pesquisa de campo foi realizada em 2016, cabe informar que nesse ano foram abertas, além das turmas do matutino, duas turmas de $2^{\circ}$ ano no vespertino, atendendo demanda de alunos que fazem estágio pela manhã, segundo a direção. Mantiveram-se concentradas as turmas do $1^{\circ}$ ano à tarde, e do $3^{\circ}$ pela manhã. Em termos de distribuição entre as séries, responderam ao questionário 107 alunos do $1^{\circ}$ ano, 102 do $2^{\circ}$ ano e 128 do $3^{\circ}$ ano.

Em termos de gênero, dos jovens que participaram da pesquisa, 55\% eram do público feminino e $41 \%$, masculino. Um aspecto a ser aperfeiçoado em uma próxima pesquisa é incluir um item denominado "outros", pois alguns jovens expuseram essa demanda expressamente. Talvez por esse motivo 4\% (14/339) dos estudantes não respondeu a essa pergunta. Este foi o maior índice de abstenção nas respostas.

Quadro 16: Gênero do público discente da Escola A

\begin{tabular}{|l|c|}
\hline \multicolumn{1}{|c|}{ Gênero } & Público Discente Escola A \\
\hline Feminino & $55 \%$ \\
\hline Masculino & $41 \%$ \\
\hline Não respondeu & $4 \%$ \\
\hline
\end{tabular}

Em termos de trabalho e gênero, foi possível aferir que dos estudantes respondentes da escola A que trabalham, cerca de $1 / 4$ é do público feminino e $1 / 3$, do masculino, conforme dados apresentados no Quadro 17. De modo geral, 25\% (85/339) dos estudantes trabalham.

Quadro 17: Porcentagem de estudantes da escola A que trabalham, por gênero

\begin{tabular}{|l|c|c|}
\hline \multicolumn{1}{|c|}{ Gênero } & Trabalha & Não trabalha \\
\hline Feminino & $23 \%$ & $77 \%$ \\
\hline Masculino & $29 \%$ & $71 \%$ \\
\hline
\end{tabular}

Desse total que trabalha, 70\% (60/85) exerce jornada de trabalho de no mínimo 20 horas semanais, conforme Quadro 18, o que prejudica significativamente seu tempo disponível para os estudos e, consequentemente, a qualidade do aprendizado. 
Quadro 18: Carga horária média de trabalho semanal do público discente ativo da escola A, conforme gênero.

\begin{tabular}{|c|c|c|c|c|}
\hline Escola A & Média de 10h & Média de 20h & Média de 30h & Média de 40h \\
\hline Discentes que trabalham & $29 \%$ & $47 \%$ & $19 \%$ & $5 \%$ \\
\hline
\end{tabular}

No Quadro 19, é possível constatar que conforme o grau de instrução das estudantes é maior, aumenta a percentagem de alunas que trabalham. Cabe salientar que 50\% das jovens que estão cursando o terceiro ano do Ensino Médio na escola A, no ano de 2016, trabalham. Entre o público masculino nessa série, são 37,5\% que exercem alguma profíssão.

Quadro 19: Percentagem de ocupação do público discente da escola A por série escolar e gênero.

\begin{tabular}{|c|c|c|}
\hline Público que trabalha & Feminino & Masculino \\
\hline $1^{\mathrm{o}}$ ano & $17 \%$ & $35 \%$ \\
\hline $2^{\mathrm{o}}$ ano & $33 \%$ & $27,5 \%$ \\
\hline $3^{\mathrm{o}}$ ano & $50 \%$ & $37,5 \%$ \\
\hline Total & $100 \%$ & $100 \%$ \\
\hline
\end{tabular}

Ainda em relação aos discentes da escola A, no quesito grau de instrução dos pais ou responsáveis, cabe destacar que cerca de $60 \%$ possuem no mínimo formação superior; $18 \%$ possuem pós-graduação incompleta e a maior concentração de pais ou responsáveis (22\%) está no nível de pós-graduação completo, conforme exposto no Quadro 20. Esse fato corrobora com a literatura de que quanto maior o grau de instrução dos pais ou responsáveis, maior o apoio familiar e maior a propensão do aluno ao estudo (TIKLY, 2010; UNESCO, 2005).

Quadro 20: Formação escolar de pais ou responsáveis do público discente da escola A

\begin{tabular}{|l|c|}
\hline \multicolumn{1}{|c|}{ Formação de Pais ou Responsáveis } & Porcentagem \\
\hline Analfabeto & $0,3 \%$ \\
\hline Fundamental incompleto & $6 \%$ \\
\hline Fundamental completo & $0,9 \%$ \\
\hline Ensino Médio incompleto & $9 \%$ \\
\hline Ensino Médio completo & $19 \%$ \\
\hline Ensino Superior incompleto & $6 \%$ \\
\hline Ensino Superior completo & $19 \%$ \\
\hline Pós-graduação incompleta & $18 \%$ \\
\hline Pós-graduação completa & $22 \%$ \\
\hline
\end{tabular}


É importante verificar que, na presente pesquisa, quanto maior o grau de instrução dos pais ou responsáveis, menor a incidência do aluno trabalhar. Cerca de $70 \%$ dos alunos que não trabalham são filhos de pais com, no mínimo, nível superior completo ou incompleto. Já em relação aos estudantes que trabalham, é curioso observar que 54\% possuem pais ou responsáveis nesse mesmo nível acadêmico, superior completo ou incompleto, conforme se pode observar no Quadro 21.

Quadro 21: Escola A - relação entre formação de pais ou responsáveis e filhos que trabalham

\begin{tabular}{|c|c|c|c|c|}
\hline Formação Pais/Responsáveis & Porcen & os que & $\begin{array}{r}\text { Porcen } \\
\text { nã }\end{array}$ & $\begin{array}{l}\text { ios que } \\
\text { m }\end{array}$ \\
\hline Analfabeto & $0 \%$ & \multirow{5}{*}{$46 \%$} & $0,5 \%$ & \multirow{5}{*}{$33 \%$} \\
\hline Fundamental incompleto & $7 \%$ & & $5 \%$ & \\
\hline Fundamental completo & $2 \%$ & & $0,5 \%$ & \\
\hline Ensino Médio incompleto & $12 \%$ & & $9 \%$ & \\
\hline Ensino Médio completo & $25 \%$ & & $18 \%$ & \\
\hline Ensino Superior incompleto & $7 \%$ & \multirow{4}{*}{$54 \%$} & $6 \%$ & \multirow{4}{*}{$67 \%$} \\
\hline Ensino Superior completo & $19 \%$ & & $18 \%$ & \\
\hline Pós-graduação incompleta & $17 \%$ & & $18 \%$ & \\
\hline Pós-graduação completa & $11 \%$ & & $25 \%$ & \\
\hline Total & $100 \%$ & & $100 \%$ & \\
\hline
\end{tabular}

\subsubsection{Perfil da Escola B}

Escola pública urbana do Distrito Federal, a escola B atende os níveis de Ensino Fundamental (anos finais); Ensino Médio e Educação de Jovens e Adultos (EJA). O Ensino Médio regular, foco da pesquisa, é oferecido nos períodos matutino e noturno.

Fundada no ano de 1979, a escola B está localizada no Plano Piloto e se encontra em uma região administrativa de alto poder aquisitivo, em uma área residencial, a cerca de oito quilômetros do centro de Brasília-DF.

\section{Gestão Escolar}

No tocante à gestão escolar, a direção informou que trabalha na escola B há 16 anos, destes 8 anos na supervisão pedagógica, 4 anos no cargo de vice-diretor e 4 anos como 
diretora. Assim, nunca atuou em sala de aula nessa escola, porém, lecionou por 26 anos em outra escola. É graduada e pós-graduada Lato sensu, em Biologia, possui Especialização em Gestão Educacional pela UnB, no ano de 2010, aproximadamente. Nos últimos dois anos não realizou nenhum curso tendo em vista a escassez de tempo o que considera "uma pena, você tem que se preparar para chegar [ao cargo de direção] porque quando você está é muito complicado, e aí a especialização ela ocorre aqui dentro a cada dia com as demandas que você tem" (Direção escola B, E2).

Segundo a direção, a gestão escolar é compartilhada e os meios de participação e contribuição na escola B são: Representante de Turma; Grêmio Estudantil (criado em 2016); Associação de Pais e Mestres (APM), Conselho de Classe e Conselho Escolar. Há também o Pré-Conselho, bastante utilizado pela direção que vai de sala em sala conversar com os alunos com vistas a colher informações de como aperfeiçoar o aprendizado de cada disciplina. Conforme explica a direção da escola B, o:

\begin{abstract}
Pré-Conselho que a gente faz com eles, eu sento com eles e falo, nós não vamos falar de professor, vamos falar de disciplina, certo, então vamos lá? Quais são as dificuldades em cada disciplina e quais são... Aquilo que você considera que o professor faz que facilita o seu aprendizado, vamos lá, eles vão falando e isso é bem legal, isso é bem legal, isso dá uma motivação para eles [...] E a gente vai trabalhando junto, eu como orientadora educacional, então quando eles falam assim, ah, o professor esteve aqui e não dá a matéria direito, fecha o caderno e fala que não vai dar mais nada porque a gente fez bagunça. Ah, então tá, vamos focar? Então [pensa] você prepara um trabalho para vir apresentar para o professor e o professor vira de costas para você, e aí, você vai estar motivado para continuar ou você vai calar? Eu vou calar. Então, você fez bagunça, então vamos mudar, vamos motivar, eis-me aqui professor, quando ele chegar vamos abrir o caderno? Vamos fazer o dever? Direção Escola B, E2).
\end{abstract}

Com isso, a direção oferece ao aluno a oportunidade de expor as suas necessidades e anseios na escola, o que empodera o aluno, incentiva a participação organizada e responsável, o que trabalha o exercício de cidadania, a negociação, a argumentação, a troca de experiência e de vivências, estimula o exercício de alteridade, a responsabilidade, o enxergar as consequências de seus atos no outro e o saber lidar com frustrações. Além de motivar o aluno, ele percebe que está sendo ouvido, respeitado, que pode contribuir com sugestões de mudança, as quais ele queira dentro da escola.

Fonte de informação, o Pré-Conselho é utilizado pela direção como forma de melhor compreender as demandas dos alunos, tanto do ponto de vista administrativo quanto pedagógico, e para poder intervir de forma mais qualificada junto à coordenação pedagógica e aos docentes. No PPP da escola B há a previsão, também, do instituto do Pós-Conselho, pelo qual é dado o retorno, o feedback, das decisões do Conselho de Classe (reuniões bimestrais) aos alunos. 
Assim como a direção da escola A destacou, a direção da escola B relata que a gestão de alguns docentes é um grande desafio:

porque professor é muito difícil, você oferece curso, você faz isso, você faz aquilo e sempre tem uma resistência, essa morosidade desse trabalho se deve à isso, a gente tem que trazer para dentro da escola, [...] porque tudo reclama, vamos para a reunião, reclama, vamos para o fórum, reclama.[...] professor é muito difícil, muito difícil, a gestão do professor é bem cansativa [...] é tão mais fácil trabalhar o aluno (Direção Escola B, E2).

Por isso, a direção se intitula "gestora de alunos". Sua estratégia é realizar o préconselho, ir para a sala de aula conversar diretamente com os estudantes: "Eu vou muito para a sala, eu faço muito pré-conselho, faço conselho, eu gosto muito de estar com eles [alunos]" (Direção Escola B, E2).

Questionada, a direção entende que "a estabilidade ela tem esse preço alto para se pagar, infelizmente. São poucos [os professores que dão trabalho], porque a grande maioria está aí dando o sangue, está fazendo a diferença, você está vendo aqui na escola, a maioria faz a diferença" (Direção Escola B, E2). Um meio de se tentar mitigar esse problema, a dirigente citou a avaliação funcional. Em implementação em outros países, segundo ela, se o docente não for bem avaliado, são dadas oportunidades a ele de se reciclar, de se melhorar enquanto profissional.

No caso da escola B, com intuito de se minimizar esse desafio, criaram o Projeto Interdisciplinar (PI). Antes de explicar do que se trata o PI, é importante esclarecer que, segundo informações obtidas na entrevista, desde 2010, 2011, quando a direção estava na função de vice, já se vinha estudando o índice do ENEM, "Por que nosso índice está ruim? O que está acontecendo? Por que essa área está desse jeito? A gente precisa estudar isso". Segundo a direção, a diretora à época cuidava bem do aspecto pedagógico.

Desde final de 2012, a equipe que assumiu a direção da escola B vem realizando experiências para a melhoria do ensino. Em 2013 estudaram o ENEM e trabalharam no convencimento dos docentes, pois, segundo a dirigente, quando ela assumiu a direção "tinha um professor aqui de matemática que ele nunca tinha pego uma prova do ENEM" (Direção Escola B -E2).

Em 2014, toda a equipe profissional estudou o Ensino Médio por meio da formação promovida pelo Pacto Nacional pelo fortalecimento do Ensino Médio (PNEM) na própria unidade escolar. Como relatou a direção escolar: "o estudo do Ensino Médio naquelas formações pedagógicas, eu acredito que tenha sido os maiores starts em relação a isso [à prática pedagógica] falando do docente" (Direção Escola B, E2). Em 2014, também, deram 
início às aulas de PI generalizadas e aplicaram provas e um simulado, tipo ENEM para os estudantes.

Segundo o PPP da escola B, por meio do PNEM "o tempo destinado à coordenação coletiva tem sido utilizado exclusivamente como período de formação [...] Os temas presentes nos cadernos de estudo, têm sido discutidos pelos professores", o que tem auxiliado na reflexão de suas práticas em sala de aula (PPP da escola B, 2014).

Em 2015 conseguiram fazer o PI em um mesmo horário para todas as turmas do turno. Assim, conseguiram fazer uma coordenação coletiva só voltada para o PI. No primeiro semestre de 2015, essa coordenação coletiva foi destinada à metodologia de estudos, adotaram um livro para auxiliá-los. No segundo semestre, um bimestre foi planejado por uma área do conhecimento e no outro bimestre outra área preparou. A direção esclareceu que o planejamento é para a escola inteira, para todos os professores, assim, planeja-se todo mundo junto, tanto a ideia quanto o material a ser trabalhado.

Semelhante às oficinas promovidas na escola A, o PI insere-se no PRC (Projeto de Redesenho Curricular) do PNEM. O PI é composto por duas aulas seguidas (de cinquenta minutos cada) por semana, sendo uma aula de informática e clube de ciências e a outra de assuntos diversificados. Esses assuntos variam de acordo com a série. No primeiro e segundo anos os professores trabalham textos e temas atuais. No terceiro ano, o foco é resolução de questões mais genéricas, interdisciplinares, do ENEM: "como essa questão aqui foi construída, como você [aluno] tem que ler essa questão, [...] o que tem nessa questão, qual o pré-requisito, o que a gente tinha que ter estudado e o que a gente estudou? Vamos lembrar, e agora vamos fazer a questão" (Direção da Escola B, E2). Nesse caso, não se trabalha apenas português e matemática, mas todas as disciplinas que possibilitam questões interdisciplinares.

Por isso, o PI foi uma estratégia para se transpor a resistência de alguns docentes e aperfeiçoar o ensino ofertado. Além de parte dos docentes, a gestão enfrentou também resistências por parte dos próprios alunos em aderir ao simulado aplicado, criado pela própria escola. Para transcender essa não adesão espontânea no ano de 2015, em 2016 o simulado tornou-se parte da avaliação do aluno no terceiro bimestre. Assim, em relação à avaliação geral do aluno, de acordo com a direção:

a prova equivale cinco pontos e ela passa a valer três e dois pontos a do simulado. Infelizmente a gente tem que fazer isso para valorizar, é uma pena, não é a filosofia que eu acho que tem que ser feita, mas a gente faz isso para valorizar que eles façam o simulado, porque no primeiro ano que nós fizemos sem dar nota houve pouca adesão, então a gente resolveu fazer isso. (Direção Escola B, E2). 
$\mathrm{Na}$ seara da avaliação do aluno cabe esclarecer que a mesma se dá da seguinte forma na escola B: dos dez pontos previstos, cinco provém de prova formal/avaliação formal. Os outros cinco pontos depende de cada docente, podem ser obtidos por meio de: elaboração de texto, apresentação de seminário, portfólio, testes com consulta ou sem consulta, varia de acordo com o professor. Segundo a direção "existe um simulado que os professores de português fazem junto com o de história e arte". Dessa forma, a escola vai montando estratégias de como melhor avaliar o aluno.

Além do pré-conselho e da abertura ao diálogo com o estudante no cotidiano, um outro canal de comunicação criado foi o Grêmio Estudantil, instituído em 2016. Ponto alto dessa motivação dos alunos, a direção declarou que a participação tem sido profícua e exemplificou:

$\mathrm{Na}$ festa junina, nós tínhamos uma gincana num modelo tradicionalíssimo nosso, que a gente já faz há anos, e o grêmio estudantil então entrou aqui, eu sou a representante da parte cultural do grêmio e gostaria de conversar com senhora e dar umas ideias, opa, senta aqui [...] estou com umas ideias aqui para a gente movimentar, o que a senhora acha, vamos fazer? Eu falei, vamos fazer, pronto, minha filha, bombou, essa tal dessa gincana e essa gincana nunca rendeu tanto como este ano. [...] isso vai fazer que ele pertencesse à escola, que goste da escola (Direção Escola B, E2).

Em termos de disciplina, dois aspectos foram destacados pela direção: uso de uniforme e pontualidade na chegada à escola. Para a direção da escola B, o uso de uniforme:

influencia no aprendizado, totalmente. [...] Eles vinham com [...] chinelo, bermuda, aí ele botava adereços, coisa na cabeça”. A escola adotou como uniforme: calça jeans (azul marinho ou preta), tênis e camiseta e não pode boné, nem colar "porque quanto mais adereço você tem mais disperso da aula você fica. [...] eu sei que é do adolescente, nós sabemos que é do adolescente, mas não é neste ambiente, existem outros dentro da sociedade para isso, este ambiente tem que ter um foco chamado estudo organizado (Direção Escola B, E2).

Com isso, a direção percebeu maior foco dos alunos nos estudos. Outro aspecto apontado foi em relação a quantidade cada vez maior de alunos que entravam somente na segunda aula. Tendo em vista a sua responsabilidade em garantir que os alunos recebam o conteúdo programático e a carga horária mínima prevista em lei, a estratégia encontrada para coibir esse tipo de abuso foi acordar com os pais no início do ano que a escola, em 2016, não iria mais permitir aluno que chega com mais de quinze minutos de atraso, exceto mediante: apresentação de atestado médico ou assinatura de um dos pais ou responsável na diretoria. Como declarou a direção:

Eles podiam chegar no segundo tempo, então quem chegasse atrasado depois tinha quinze minutos de tolerância só entraria no segundo tempo, e aí eu estava recebendo assim, duas turmas inteiras no segundo tempo, sessenta, setenta alunos, você entendeu, aí este ano o que eu fiz, eu chamei os pais no começo do ano antes de começar as aulas, falei, olha pai, o negócio é o seguinte, neste ano nós não vamos 
permitir mais, o aluno tem quinze minutos de tolerância, se ele não vier... então ele não vai entrar, ele só vai entrar se o senhor estiver presente e não é lá no estacionamento não, é aqui comigo para assinar que chegou com atraso, ou mediante atestado [...] Tudo bem pais, vocês concordam? Beleza? Beleza (Direção Escola B, E2).

Por esse motivo, segundo a direção ela é acusada por alguns alunos de ditadora: "não tem problema, se é para ditar uma escola de qualidade eu sou a líder", pontuou a Direção da Escola B. A dirigente tem conhecimento das normas legais, de que:

Você nunca pode impedir um aluno de entrar em sala, jamais, nem por uniforme, nem por horário, nem por nada, você não pode, eu sei disso, mas o aluno não pode fazer disso aqui um local de não aprendizado, porque se ele chegar no ENEM quinze minutos mais tarde, ele não pode entrar? Ele não pode, só que eu estou ensinando ele o errado, eu estou ensinando para ele que ele pode, nós cortamos. (Direção Escola B, E2).

Após esse ajuste, o índice de falta, segundo informou, é quase nulo, porque "aqueles que chegavam atrasados por burlar a coisa, que iam no Carrefour lanchar, esses pararam porque eles vêm no ônibus e o pai sabe que ele saiu" (Direção Escola B, E2). A escola só não obteve sucesso com os alunos provenientes de escola particular, público que tem aumentado na escola. Com melhor condição aquisitiva, são aqueles que o pai ou a mãe levam de carro para a escola. De acordo com a direção:

os alunos da escola particular, esses não deram certo [com esses a estratégia não deu certo] [...] porque chegam e não estão acostumados com outro tipo de rigidez, você entendeu, aí, ah, é um absurdo, aí o pai vem, de novo eu atrasei. Senhor, o senhor não pode, tem limite para o senhor inclusive vir acompanhando ele, porque o senhor não tem o direito de reduzir o horário de aula dele (Direção Escola B, E2).

O comportamento dessas famílias tem afetado, inclusive, a educação dos demais alunos, afirmou a direção escolar.

É preciso destacar que é da responsabilidade da direção escolar a garantia e a fiscalização da carga horária de ensino recebida pelo aluno, caso contrário, é preciso acionar os pais no Conselho Tutelar.

\section{Financiamento}

De acordo com o PPP, a gestão administrativa e financeira da escola B é feita de forma integrada entre a Direção, o Conselho Escolar e a Associação de Pais e Mestres, que em reuniões específicas deliberam a respeito da gestão dos recursos oriundos dos governos federal, distrital e de contribuição voluntária.

Em relação os recursos recebidos pela escola B no período de 2012 a 2016, como ocorreu na pesquisa de campo da escola A, observou-se divergência entre os dados fornecidos 
pela escola, pelo GDF e pelo FNDE. Por esse motivo, as mesmas fontes utilizadas para apresentação dos dados de financiamento da escola A foram usadas para a escola B.

Dessa forma, no tocante aos repasses realizados pelo Governo Distrital, optou-se por apresentar os valores fornecidos pela própria escola. Em relação aos repasses federais, utilizaram-se os dados obtidos no sítio eletrônico do FNDE. No Quadro 22 apresentam-se os valores recebidos pela escola B no período de 2012 a 2016, segundo essas fontes.

Quadro 22: Recursos financeiros recebidos pela Escola B no período de 2012 a 2016.

\begin{tabular}{|c|c|c|c|c|c|c|}
\hline Escola B & Verba & $\begin{array}{c}2012 \\
(\mathrm{R} \$)\end{array}$ & $\begin{array}{c}2013 \\
(\mathrm{R} \$)\end{array}$ & $\begin{array}{c}2014 \\
(\mathrm{R} \$)\end{array}$ & $\begin{array}{c}2015 \\
(\mathrm{R} \$)\end{array}$ & $\begin{array}{c}2016 \text { (até } \\
\text { novembro) } \\
(\mathrm{R} \$)\end{array}$ \\
\hline \multirow{2}{*}{ PDAF } & CAPITAL & $25.000,00$ & 0,00 & 0,00 & 0,00 & 0,00 \\
\cline { 2 - 7 } & CUSTEIO & $69.000,00$ & 0,00 & $45.000,00$ & $79.000,00$ & $36.500,00$ \\
\hline PDDE & GLOBAL & $3.650,00$ & $18.300,00$ & $8.300,00$ & 0,00 & 0,00 \\
\hline PROEMI & GLOBAL & $40.000,00$ & 0,00 & $40.000,00$ & 0,00 & 0,00 \\
\hline TOTAL & GLOBAL & $137.650,00$ & $18.300,00$ & $93.300,00$ & $79.000,00$ & $36.500,00$ \\
\hline
\end{tabular}

Fonte: Escola B e FNDE

Como é possível observar, os valores recebidos pela escola B variaram muito a cada ano. Do Governo do Distrito Federal, de acordo com dados fornecidos pela direção escolar, a escola B obteve, no ano de 2012, o montante de $\mathrm{R} \$ 94.000,00$ por meio do PDAF, sendo $\mathrm{R} \$ 25.000,00$ para despesas de capital e $\mathrm{R} \$ 69.000,00$ para despesas com custeio. No ano de 2013, segundo a direção não houve repasse do GDF. Nos anos subsequentes, 2014, 2015, os valores repassados por meio do PDAF foram $\mathrm{R} \$ 45.000,00$ e 79.000,00, respectivamente, ambos para despesas com custeio. E, a título de acompanhamento, até novembro de 2016 a escola havia recebido do GDF R $\$ 36.500,00$, também para custeio.

Em relação aos recursos provenientes da União, de acordo com dados obtidos junto ao FNDE, a escola B recebeu, por meio do PDDE R\$3.650,00 no ano de 2012; $\mathrm{R} \$ 18.300,00$ em 2013 , e $\mathrm{R} \$ 8.300,00$, no ano de 2014. Por meio desse programa não consta repasse à escola B em 2015 e 2016. No tocante ao ProEMI, segundo dados do FNDE a escola recebeu $\mathrm{R} \$ 40.000,00$ no ano de 2012 e o mesmo valor em 2014, não havendo repasse à escola B por meio desse programa nos demais anos.

Com isso, observa-se que houve queda significativa no repasse de recursos tanto pelo Governo Federal quanto Distrital no período analisado, o que dificulta o planejamento adequado da gestão escolar tanto administrativa como pedagógica. Enquanto em 2012 a escola B recebeu um valor total de $\mathrm{R} \$ 137.650,00$, em 2013 o montante total recebido pela 
escola foi de $\mathrm{R} \$ 18.300,00$. Nos anos 2014 e 2015, foram repassados $\mathrm{R} \$ 93.300,00$ e $\mathrm{R} \$ 79.000,00$, respectivamente. E, até novembro de 2016, a escola B contou apenas com recursos do GDF no valor de $\mathrm{R} \$ 36.500,00$.

Como fonte adicional, quando necessário e a depender da demanda, a escola B recorre à APM, a qual tem auxiliado na melhoria das condições de infraestrutura da escola, diferente da escola A que não conta com essa fonte colaborativa. Como exemplos, a APM da escola B custeou a instalação e a manutenção, em cada sala de aula, de ares condicionados adquiridos pela Secretaria de Educação do DF. Como o telhado aquece muito, as salas ficavam quentes, o que prejudicava a concentração e o aprendizado dos alunos. Outra benfeitoria realizada na escola, por meio da APM, foi a compra de armários individualizados, com cadeado, nos quais alunos e toda a comunidade escolar pode guardar os seus pertences.

É interessante destacar que a gestão financeira também é compartilhada com os alunos. Para além da APM e do Conselho Escolar, quando possível, a direção pergunta aos alunos diretamente onde melhor aplicar o recurso. Como exemplo, a escola B recebeu $\mathrm{R} \$ 700,00$ (setecentos reais) rubricado para compra de livros para a Feira do Livro. Para a escolha dos livros, a direção pediu aos alunos que trouxessem:

(...) sugestões de livros. Um dia tinha uma lista aqui imensa, você entendeu, eles foram na biblioteca eu falei, e eu não quero livro repetido, se eu tiver ali na biblioteca com livro que vocês estão pedindo eu não aceito, não tinha um livro, porque eu fui [checar], eu também faço a minha parte, mas eu vou lá atrás, tem, tem, não, então fizeram o dever de casa. [...] isso vai fazendo com que eles se apropriem da escola, eles gostem da escola (Direção Escola B, E2).

\section{Missão e Objetivo Geral da Escola B}

De acordo com o PPP, a escola B tem por missão:

Conquistar uma educação democrática e livre, com ensino de excelência, proporcionando condições para a formação de pessoas que se auto realizem, sejam felizes e participem construtivamente da sociedade em prol da justiça social, convivência harmônica e respeito mútuo.

A valorização e a formação geral do educando é enfatizada pelo espírito de equipe, a participação e principalmente a tomada de decisões conjuntas para um futuro melhor para todos.

A escola, no sentido mais amplo, deve ser o lugar onde a diversidade de opiniões sejam praticadas. Esta visão faz com que [a escola B] tenha a missão de formar indivíduos mais participativos, responsáveis por sua aprendizagem, críticos, transformadores de novas realidades, sem haver qualquer benefício de partes, construindo um mundo mais justo e igualitário (PPP Escola B, 2014, p. 7).

Na pesquisa foi possível observar que essa missão tem sido buscada de forma gradativa com a criação de canais de comunicação com o estudante, tais como Representante de Turma, Grêmio Estudantil, Pré-Conselho e Conselho Escolar. E com a tomada de decisões conjuntas, o que possibilita e estimula a participação do aluno na construção da escola que se 
almeja. Dessa forma, a escola tem buscado "formar indivíduos mais participativos, responsáveis por sua aprendizagem, críticos, transformadores de novas realidades" (PPP Escola B, 2014, p. 7).

A criação do Grêmio Estudantil era um dos objetivos previstos no PPP da escola B (2014), a ser fomentado pela equipe escolar, e que se tornou realidade no ano de 2016.

\section{Projetos e Parcerias}

Entre os projetos desenvolvidos pela escola B estão:

- Clube de Ciências. Por três anos (2013 a 2015) ofereceram iniciação à robótica por meio do Mais Educação. Promovido por alunos da UnB que vinham uma tarde inteira por semana ensinar alunos do Ensino Médio.

- Projeto Re(vi)vendo Êxodos, por meio do ProEMI promovido pelo MEC. Nele, a escola trabalha questões de história, cultura, leitura e letramento por meio dos temas: patrimônio, identidade e meio ambiente, sob o aspecto da formação do Distrito Federal. Criado a partir de uma exposição do fotógrafo Sebastião Salgado, esse projeto é realizado, segundo a direção, em parceria com mais três escolas públicas do DF. A partir das cidades vizinhas, é feita uma saída a campo de 15 dias de caminhada. Nesse período, os alunos conhecem as cidades do entorno e toda a história de formação de Brasília. Com apoio do Exército, que promove a segurança e o acampamento, ao todo participam cerca de oitenta alunos, das quatro escolas envolvidas. Esse trabalho, além de propiciar uma pausa no cotidiano do aluno, possibilita o conhecimento da realidade e estimula a troca de experiências entre os participantes, algo muito rico em termos de educação, e ao mesmo tempo, raro no cotidiano atual das grandes cidades.

Já em termos de parceria, a escola B possui parceria, também, com a embaixada dos Estados Unidos (EUA), pela qual os alunos podem acessar a biblioteca da Thomas Jefferson, inclusive sites de museus americanos. Segundo a Direção: "Eles ficaram impressionados com a quantidade [de livros] que os alunos leram e com a quantidade de alunos que tenha ido [...] aí começou a parceria” (Direção da Escola B, E2).

A embaixatriz visitou a escola e divulgou o projeto Embaixador do Futuro e trouxe alunos de escolas carentes do DF que já tinham ido para os EUA por meio do projeto. Para participar o aluno precisa passar por uma seleção, ter algum conhecimento em inglês e ter prestado algum trabalho voluntário à comunidade por pelo menos um ano. É considerado trabalho comunitário: ser representante de classe, participar do grêmio estudantil, participar de 
trabalhos em alguma igreja ou outra entidade reconhecida. Para os selecionados, a embaixada custeia passagens e estadia por algumas semanas nos EUA.

Isso demonstra o papel do estudante frente às oportunidades. Se os alunos não tivessem aproveitado a chance de uso da biblioteca, talvez a parceria com a embaixada não tivesse sido estabelecida com a escola. Com isso, a escola B recebeu doação de livros em inglês; os alunos que mais leram foram premiados e os estudantes continuam podendo acessar a biblioteca da Thomas Jefferson e tudo o que ela oferece, além de serem incentivados a participar do projeto Embaixador do Futuro.

\section{Infraestrutura Física da Escola B}

No tocante à infraestrutura física, a escola B possui: onze salas de aula, dois laboratórios de ciências (de física e de biologia), laboratório de informática, sala de vídeo, biblioteca, secretaria escolar, sala dos professores, sala de leitura, mecanografia e audiovisual (sala de reprografia e onde os equipamentos eletrônicos são guardados), sala da coordenação, direção, supervisores/assistência, sala dos Servidores, orientação educacional, sala de recursos generalista, depósito de material, cozinha, cantina, sanitários, quadra de esportes descoberta, guarita e outros (PPP da escola B, 2014).

Como na escola A, uma demanda apresentada pela direção, pelos docentes e pela coordenação pedagógica foi a construção de um auditório para a promoção de atividades mais amplas na escola. Outra necessidade apontada pela comunidade escolar da escola B é a cobertura da quadra de esportes.

\section{Coordenação Pedagógica da Escola B}

Como mencionado na metodologia, na escola B colaboraram com a pesquisa a coordenadora pedagógica do matutino, assim como uma supervisora pedagógica e uma orientadora educacional, ambas do noturno. Para que o anonimato dos participantes fosse preservado, optou-se por expor os resultados dessas profissionais em conjunto, mantendo-se a nomenclatura nos quadros e nas análises como coordenação pedagógica.

O cargo de coordenador pedagógico, conforme já exposto, é regulado pela Secretaria de Estado de Educação, Esporte e Lazer do DF. Entre os pré-requisitos para exercício no cargo, observa-se que não é requerida nenhuma capacitação específica prévia para atuação do docente como coordenador pedagógico. Fato apontado por participante da escola B como bastante prejudicial para a melhoria da qualidade da educação ofertada. 
Posto isso, no tocante ao perfil dos coordenadores da escola B (incluindo supervisor pedagógico e orientador educacional), é relevante observar que dois lecionaram mais de 10 anos em sala de aula, um deles na escola B, o que é bastante positivo no sentido de que conhece a realidade e os desafios da prática na escola pesquisada. Ademais, dois têm formação acadêmica em nível de especialização e um está concluindo o mestrado.

$\mathrm{Na}$ função de coordenador pedagógico, supervisor pedagógico ou orientador educacional, a quantidade de anos de experiência nessa função varia de 1 a mais de 3 anos. Porém, na escola B nessa função, menos de três anos. Em relação ao total de capacitações voltadas à educação, realizadas nos últimos 2 (dois) anos, variou entre 1, 2 e 4 ou mais. No Quadro 23 apresenta-se um resumo do exposto.

Quadro 23: Perfil da Coordenação Pedagógica da Escola B.

\begin{tabular}{|c|c|c|c|c|c|c|}
\hline $\begin{array}{c}\text { Coordenador } \\
\text { Pedagógico } \\
\text { Escola B }\end{array}$ & $\begin{array}{c}\text { Atua nessa } \\
\text { função }\end{array}$ & $\begin{array}{c}\text { Nessa } \\
\text { função na } \\
\text { Escola B }\end{array}$ & $\begin{array}{c}\text { Experiência } \\
\text { em sala de } \\
\text { aula }\end{array}$ & $\begin{array}{c}\text { Lecionou } \\
\text { na } \\
\text { Escola B }\end{array}$ & $\begin{array}{c}\text { Formação } \\
\text { acadêmica }\end{array}$ & $\begin{array}{c}\mathrm{N}^{\text {o de }} \\
\text { capacitações } \\
\text { nos últimos } \\
2 \text { anos }\end{array}$ \\
\hline 1 & $\begin{array}{c}\text { de } 1 \text { a } 2 \\
\text { anos }\end{array}$ & $\begin{array}{c}\text { de } 1 \text { a } 2 \\
\text { anos }\end{array}$ & $\begin{array}{c}\text { mais de } 10 \\
\text { anos }\end{array}$ & $\begin{array}{c}\text { mais de } \\
10 \text { anos }\end{array}$ & Especialização & 1 \\
\hline 2 & $\begin{array}{c}\text { mais de } 3 \\
\text { anos }\end{array}$ & $\begin{array}{c}\text { de } 1 \text { a } 2 \\
\text { anos }\end{array}$ & $\begin{array}{c}\text { de } 5 \text { a } 10 \\
\text { anos }\end{array}$ & $\begin{array}{c}\text { de 1 a 3 } \\
\text { anos }\end{array}$ & $\begin{array}{c}\text { Mestrado em } \\
\text { conclusão }\end{array}$ & 4 ou mais \\
\hline 3 & de 2 a 3 anos & $\begin{array}{c}\text { de } 2 \text { a 3 } \\
\text { anos }\end{array}$ & $\begin{array}{c}\text { mais de } 10 \\
\text { anos }\end{array}$ & nunca & Especialização & 2 \\
\hline
\end{tabular}

Diante desse contexto, na escola B observa-se que apenas um profissional atuava nessa função em 2014, e um trabalhava como docente em sala de aula no período analisado de 2012 a 2014.

Em termos de planejamento e prática pedagógica, segundo o PPP e a direção escolar, a escola B busca:

- Realizar avaliação diagnóstica construída coletivamente pelos professores;

- Garantir uma prática metodológica de ensino visando um aprendizado eficaz por meio de planejamento pelo qual os alunos sejam protagonistas de sua aprendizagem. Como exemplo, a escola disponibiliza, no contra turno das aulas, reforço escolar em horários de coordenação. Para isso, basta o aluno agendar previamente com o docente da disciplina;

- Estimular a participação dos alunos em Olimpíadas de conhecimento;

- Participar da Semana Profissional da UnB;

- Apresentar exemplos de sucesso para os alunos, por meio de vídeos; 
- Promover Gincana Interna (cultural e artística); show de talentos;

- Ação de ajuda solidária;

- Preservação do meio-ambiente e do patrimônio;

- Ampliar o acesso à informação, disponibilizando acesso à internet.

\section{Público Docente da Escola B (Perfil)}

Salienta-se que, na pesquisa de campo realizada na escola $B$, responderam ao questionário: 10 dos 13 docentes do diurno; e 5 dos 11 professores do noturno. Com isso, ao todo 15 docentes colaboraram com o estudo. A seguir apresentamos o perfil do público docente que respondeu à pesquisa.

No tocante à experiência, 93\% dos respondentes, ou 14 docentes, informaram possuir mais de 10 anos de atuação na área de docência; e 7\%, entre 0 e 5 anos de experiência, conforme demonstrado no Quadro 24.

Quadro 24: Docentes da escola B, anos de experiência na área

\begin{tabular}{|c|c|}
\hline 0 a 5 anos & acima de 10 anos \\
\hline $7 \%$ & $93 \%$ \\
\hline
\end{tabular}

Em relação aos anos de atuação na escola B, verificou-se que, dos pesquisados, cerca de $60 \%$ (9 docentes) leciona na escola B há mais de três anos; $20 \%$ trabalha na escola há menos de 1 ano e outros 20\%, entre 1 e 2 anos, conforme Quadro 25.

Quadro 25: Quantos anos atuam na escola B

\begin{tabular}{|c|c|c|}
\hline menos de 1 ano & de 1 a 2 anos & acima de 3 anos \\
\hline $20 \%$ & $20 \%$ & $60 \%$ \\
\hline
\end{tabular}

Em entrevista realizada com a direção escolar (E2), pode-se confirmar que a escola possui um grau de rotatividade razoável, só em 2015 foram cerca de cinco aposentadorias, sendo que em 2016, as duas cadeiras de Língua Portuguesa foram preenchidas por professores novos na escola. Como na escola A, esse fato dificulta a implementação do PPP da escola e a maturação da proposta pedagógica, o que, consequentemente, prejudica a possibilidade de melhoria da qualidade do ensino ofertado.

Dos respondentes, 6 lecionam na área de Linguagens (Língua Portuguesa; Inglês/Espanhol; Artes, Educação Física; Tecnologias da Informação e Comunicação); 5 são professores na área de Ciências da Natureza (Biologia; Física, Química e Matemática) e 4 de Ciências Humanas (História; Geografia; Filosofia e Sociologia). 
Quadro 26: Área de atuação dos professores que participaram da pesquisa na escola B

\begin{tabular}{|c|c|c|}
\hline $\begin{array}{c}\text { Linguagens: Língua Portuguesa; } \\
\text { Inglês/Espanhol; Artes, } \\
\begin{array}{c}\text { Educação Física; Tecnologias da } \\
\text { Informação e Comunicação }\end{array}\end{array}$ & $\begin{array}{c}\text { Ciências da Natureza: } \\
\text { Biologia; Física, Química e } \\
\text { Matemática }\end{array}$ & $\begin{array}{c}\text { Ciências Humanas: História; } \\
\text { Geografia; Filosofia e } \\
\text { Sociologia }\end{array}$ \\
\hline $40 \%$ & $33 \%$ & $27 \%$ \\
\hline
\end{tabular}

No tocante à formação acadêmica, conforme o Quadro 27, 14\% tem formação em graduação, e $86 \%$ concluiu ou cursa pós-graduação: $66 \%$ em nível de especialização e $20 \%$, mestrado. Ao todo, 4 , ou $27 \%$, informaram terem realizado pós-graduação em área diversa da qual lecionam, todos os demais aperfeiçoaram-se na disciplina que ministram. Ademais, todos os respondentes possuem formação em licenciatura.

Quadro 27: Formação acadêmica (grau concluído ou em conclusão) dos docentes participantes da pesquisa da escola B.

\begin{tabular}{|c|c|c|c|}
\hline Graduação & Especialização & Mestrado & Doutorado \\
\hline $14 \%$ & $66 \%$ & $20 \%$ & $0 \%$ \\
\hline
\end{tabular}

Esses dados demonstram que a escola possui capital humano qualificado em termos de formação acadêmica, porém, há dissonância com o índice de adequação da formação docente auferido pelo INEP, pelo qual 70\% dos docentes possuíam formação adequada em 2015 (INEP, 2016b). Esse dado revela que 30\% dos professores da escola B não possuem "formação superior de licenciatura na mesma disciplina que lecionam, ou bacharelado na mesma disciplina com curso de complementação pedagógica concluído" (INEP, 2014b, p. 5).

De acordo com dados obtidos junto ao INEP, foi possível verificar que o baixo índice obtido pela escola B em 2014 foi em razão do número de docentes classificados em grau três (docentes com licenciatura em área diferente daquela que leciona), ao todo oito docentes; assim como dois professores classificados em grau quatro (docentes com outra formação superior não considerada nas categorias anteriores). Nesse ano, a escola possuía 16 docentes classificados em grau 1 (docentes com formação superior de licenciatura na mesma disciplina que lecionam), conforme demonstrado no Quadro 28.

Quadro 28: Composição do Índice de Adequação da Formação Docente na Escola B em 2014.

\begin{tabular}{|c|c|l|}
\hline Grau & Total de Docentes & \multicolumn{1}{c|}{ Disciplinas } \\
\hline 1 & 16 & Todas, exceto Sociologia e Educação Física \\
\hline 3 & 8 & $\begin{array}{l}\text { Biologia, Química, História, Geografia, 2 Sociologia, 3 Língua } \\
\text { Estrangeira }\end{array}$ \\
\hline 4 & 2 & Educação Física \\
\hline
\end{tabular}

Fonte: INEP, 2015a. 
Cabe observar que, entre os docentes classificados em grau 3, em 2014, um ministra duas disciplinas, Biologia e Química; dois lecionam Sociologia e três, Língua Estrangeira.

No ano de 2015, esse índice subiu de 60\% para 70\%. Apesar de ter melhorado em relação a 2014, de acordo com dados obtidos junto ao INEP (INEP, 2016a), foi possível verificar que o que limitou o seu aumento foi um docente classificado em grau 5 (Língua Portuguesa); dois docentes já classificados em grau 4 (Educação Física); quatro profissionais classificados em grau 3 (História, Química, Língua Estrangeira e Sociologia) e um em grau 2 (Geografia). Ao todo foram 18 docentes classificados em grau 1 (todas as disciplinas, exceto Educação Física), conforme Quadro 29.

Quadro 29: Composição do Índice de Adequação da Formação Docente da Escola B em 2015.

\begin{tabular}{|c|c|l|}
\hline Grau & Total de Docentes & Disciplinas \\
\hline 1 & 18 & Todas, exceto Educação Física \\
\hline 2 & 1 & Geografia \\
\hline 3 & 4 & Química, História, Sociologia, Língua Estrangeira \\
\hline 4 & 2 & Educação Física \\
\hline 5 & 1 & Língua Portuguesa \\
\hline
\end{tabular}

Fonte: INEP, 2016a.

Em relação às capacitações voltadas à docência, apesar dos incentivos dado pelo GDF, de reservar parte da carga horária semanal dos docentes para aperfeiçoamento e de ofertar cursos por meio da EAPE, $27 \%$ dos docentes que responderam à pesquisa não se aperfeiçoaram nos últimos dois anos. Isso permite inferir que um terço do quadro não está se aperfeiçoamento em termos de ideias, nem de troca de experiências para a melhoria da qualidade da educação ofertada. No cômputo geral, somente $13 \%$ docentes do turno matutino realizaram duas capacitações nos últimos dois anos e 7\% dos docentes do noturno, 4 ou mais cursos, conforme Quadro 30.

Quadro 30: Número de capacitações realizadas nos últimos 2 (dois) anos pelos docentes da escola B.

\begin{tabular}{|c|c|c|c|c|}
\hline 0 & 1 & 2 & 3 & 4 ou mais \\
\hline $27 \%$ & $53 \%$ & $13 \%$ & $0 \%$ & $7 \%$ \\
\hline
\end{tabular}

Metade dos docentes que colaboraram com a pesquisa de campo realizou um curso nos últimos dois anos. O que não foi possível confirmar é se essa capacitação foi em nível de pós-graduação ou de aperfeiçoamento em geral. 


\section{Perfil do Público Discente da Escola B}

Como a escola B está localizada em uma área residencial de alto poder aquisitivo, cumpre destacar que a maior parte do seu público discente reside longe da escola ou trabalha e reside nas casas próximas. De acordo com o PPP da escola, há alunos provenientes das regiões administrativas do Paranoá, São Sebastião, Jardim Botânico, assim como de cidades goianas do entorno, tais como Valparaíso e Jardim ABC, distantes entre 15 e 35 quilômetros da escola.

Por esse motivo, conforme entrevista concedida pela direção, a escola não possui uma identidade própria em razão dos alunos serem provenientes de, pelo menos, cinco bairros distantes, sendo a escola o ponto central destes. Cabe salientar que os alunos contam com transporte público gratuito, ou por meio do "Passe Livre Estudantil" oferecido pelo Governo do Distrito Federal desde o ano de 2010 ou por meio dos ônibus escolares que servem a escola B.

Em termos de contextualização do público discente, para além do desempenho dos estudantes no ENEM, a escola B esteve entre as 10 mais bem classificadas no ENEM 2014 entre as escolas públicas regulares do DF, verifica-se que os alunos possuem um nível socioeconômico médio alto, característica verificada em $60 \%$ das escolas públicas do DF.

Segundo Nota Técnica do INEP, o nível socioeconômico médio alto indica que, de modo geral, os alunos possuem renda familiar mensal entre 1 e 5 salários mínimos; acesso à internet e o pai e a mãe (ou responsáveis) possuem ensino fundamental completo ou estão cursando esse nível de ensino (INEP, 2014a).

Segundo dados da Secretaria de Educação do Distrito Federal, a escola B possuía, nos anos de 2012 a 2015, entre 400 e 480 alunos do Ensino Médio matriculados por ano.

$\mathrm{Na}$ escola B, o Ensino Médio regular concentra-se no período matutino e em parte do noturno. No turno vespertino a escola oferece os anos finais do ensino fundamental. Em termos de número de alunos por sala, no período analisado de 2012 a 2015, turno matutino, a média de alunos por sala de aula foi de 36 estudantes no $1^{\circ}$ ano; e 39 , no $3^{\circ}$ ano. No $2^{\circ}$ ano, houve maior variação nesse período: 26, 37, 33 e 39 alunos, respectivamente. No noturno, foi oferecido uma turma de cada série por ano. $\mathrm{O}$ número de alunos por sala variou conforme demonstrado no Quadro 31. 
Quadro 31: Escola B: turmas, alunos por turma, série e turno, no período de 2012 a 2015.

\begin{tabular}{|c|c|c|c|c|c|}
\hline \multicolumn{3}{|c|}{ Ano 2012 - MATUTINO } & \multicolumn{3}{|c|}{ Ano 2012 - NOTURNO } \\
\hline Série & $\mathrm{N}^{0}$ de turmas & $\begin{array}{c}\text { Média de } \\
\text { alunos/turma }\end{array}$ & Série & $\mathrm{N}^{0}$ de turmas & $\begin{array}{c}\text { Média de } \\
\text { alunos/turma }\end{array}$ \\
\hline $1^{\circ}$ ano & 4 & 38 & $1^{\circ}$ ano & 1 & 35 \\
\hline $2^{\circ}$ ano & 3 & 26 & $2^{\circ}$ ano & 1 & 28 \\
\hline $3^{\circ}$ ano & 2 & 41 & $3^{\circ}$ ano & 1 & 28 \\
\hline \multicolumn{3}{|c|}{ Ano 2013 - MATUTINO } & \multicolumn{3}{|c|}{ Ano 2013 - NOTURNO } \\
\hline Série & $\mathrm{N}^{\mathrm{o}}$ de turmas & $\begin{array}{c}\text { Média de } \\
\text { alunos/turma }\end{array}$ & Série & $\mathrm{N}^{\mathrm{o}}$ de turmas & $\begin{array}{c}\text { Média de } \\
\text { alunos/turma }\end{array}$ \\
\hline $1^{\circ}$ ano & 4 & 36 & $1^{\circ}$ ano & 1 & 41 \\
\hline $2^{\circ}$ ano & 3 & 37 & $2^{\circ}$ ano & 1 & 28 \\
\hline $3^{\circ}$ ano & 2 & 38 & $3^{\circ}$ ano & 1 & 23 \\
\hline \multicolumn{3}{|c|}{ Ano 2014 - MATUTINO } & \multicolumn{3}{|c|}{ Ano 2014 - NOTURNO } \\
\hline Série & $\mathrm{N}^{\mathrm{o}}$ de turmas & $\begin{array}{c}\text { Média de } \\
\text { alunos/turma }\end{array}$ & Série & $\mathrm{N}^{0}$ de turmas & $\begin{array}{c}\text { Média de } \\
\text { alunos/turma }\end{array}$ \\
\hline $1^{\circ}$ ano & 5 & 35 & $1^{\circ}$ ano & 1 & 33 \\
\hline $2^{\circ}$ ano & 3 & 33 & $2^{\circ}$ ano & 1 & 26 \\
\hline $3^{\circ}$ ano & 2 & 38 & $3^{\circ}$ ano & 1 & 21 \\
\hline \multicolumn{3}{|c|}{ Ano 2015 - MATUTINO } & \multicolumn{3}{|c|}{ Ano 2015 - NOTURNO } \\
\hline Série & $\mathrm{N}^{\mathrm{o}}$ de turmas & $\begin{array}{c}\text { Média de } \\
\text { alunos/turma }\end{array}$ & Série & $\mathrm{N}^{\circ}$ de turmas & $\begin{array}{c}\text { Média de } \\
\text { alunos/turma }\end{array}$ \\
\hline $1^{\circ}$ ano & 4 & 39 & $1^{\circ}$ ano & 1 & 36 \\
\hline $2^{\circ}$ ano & 4 & 39 & $2^{\circ}$ ano & 1 & 25 \\
\hline $3^{\circ}$ ano & 2 & 40 & $3^{\circ}$ ano & 1 & 32 \\
\hline
\end{tabular}

No tocante ao índice Defasagem Idade/Série, no turno matutino da escola B, o $1^{\circ}$ ano possui índice de $29 \%$ de estudantes com idade defasada para a série; no $2^{\circ}$ ano, $24 \%$ e no $3^{\circ}$ ano, 14\%. Como ocorreu em relação aos alunos da escola $\mathrm{A}$, há menos alunos defasados no $3^{\circ}$ ano do que no $1^{\circ}$ e $2^{\circ}$ anos na escola B. No caso do noturno, o índice de defasagem é bem alto, $100 \%$ no $1^{\circ}$ ano; $88 \%$ no $2^{\circ}$ ano e $69 \%$ no $3^{\circ}$ ano.

Segundo a direção da escola B, o fato de a escola oferecer os anos finais do ensino fundamental prepara e adapta parte dos alunos que permanecerão no Ensino Médio na escola. Apesar disso, nos últimos anos (2015 e 2016), segundo a direção, houve um aumento do número de estudantes provenientes de escolas particulares no Ensino Médio, o que tem dificultado a manutenção do foco e da disciplina na escola. Provenientes de outra realidade, a direção tem empenhado esforço adicional na adaptação dos novos alunos às regras e ao modo de funcionamento da escola.

Já no tocante ao turno noturno, a realidade é outra. O público discente é destacadamente diferenciado, a começar pelo índice defasagem idade/série, que é bastante alta (média geral de 86\%), conforme se pode verificar no Quadro 31. De acordo com a direção e com os docentes do noturno, a formação dos alunos é mais baixa e requer atenção diferenciada e trabalho diversificado para atender todas as demandas. 


\section{Perfil do Público Discente da Escola B que participou da pesquisa}

Na pesquisa realizada na escola B, de um total de 457 alunos do Ensino Médio regular em 2016, responderam ao questionário aplicado 415 estudantes.

Cabe informar que as turmas do Ensino Médio regular se concentram nos turnos matutino e noturno. No período vespertino a escola atende os anos finais da etapa do ensino fundamental. Participaram da pesquisa 369 alunos da manhã, de um total de 393, e 46 do noturno, de um total de 64 alunos. Em termos de distribuição entre as séries, responderam ao questionário, 141 alunos do $1^{\circ}$ ano, 123 do $2^{\circ}$ ano e 150 do $3^{\circ}$ ano.

Semelhante ao público discente da escola $\mathrm{A}$, em termos de gênero, dos jovens que participaram da pesquisa na escola $\mathrm{B}, 56 \%$ eram do público feminino e $41 \%$, masculino. E também houve um grande número de abstenções nessa questão, 3\% (13/415) dos estudantes não responderam a essa pergunta.

Quadro 32: Gênero do público discente da Escola B

\begin{tabular}{|l|c|}
\hline \multicolumn{1}{|c|}{ Gênero } & Público Discente Escola B \\
\hline Feminino & $56 \%$ \\
\hline Masculino & $41 \%$ \\
\hline Não respondeu & $3 \%$ \\
\hline
\end{tabular}

Destaca-se que o público discente do noturno da escola B é reduzido, tendo apenas uma turma de cada série do Ensino Médio regular. Assim como diferenciado do perfil dos estudantes do matutino, conforme exposto pela direção e por docentes da escola. Tendo em vista possuir característica distinta, optou-se por apresentar alguns resultados de modo separado para propiciar uma análise mais aproximada dos públicos discentes do diurno das escolas A e B e para se ter uma visão mais real das necessidades no noturno.

Posto isso, dos alunos da escola B que responderam a essa questão, foi possível aferir que trabalham: $24 \%$ dos estudantes do matutino e $58 \%$ do noturno. Cabe esclarecer que responderam a essa pergunta: 363 estudantes do matutino e 36 do noturno.

Em termos de gênero, no turno da manhã não houve diferenciação entre os públicos feminino e masculino. Já no noturno, $67 \%$ dos alunos trabalham, contra $54 \%$ do público feminino, conforme apresentado no Quadro 33. 
Quadro 33: Porcentagem de estudantes da escola B que trabalham, por gênero e turno.

\begin{tabular}{|l|c|c|}
\hline \multirow{2}{*}{ Gênero } & \multicolumn{2}{|c|}{ Trabalham } \\
\cline { 2 - 3 } & Matutino & Noturno \\
\hline Feminino & $24 \%$ & $54 \%$ \\
\hline Masculino & $24 \%$ & $67 \%$ \\
\hline
\end{tabular}

Do total de estudantes da escola B do turno matutino que trabalha quase $90 \%$ (77/87) exerce jornada de trabalho de no mínimo 20 horas semanais, conforme Quadro 34, o que prejudica significativamente seu tempo disponível para os estudos e, consequentemente, para a qualidade do aprendizado escolar.

Em relação aos discentes do turno da noite da escola B, foi possível observar certa dificuldade dos alunos do $3^{\circ}$ ano em saber e fazer a conta da quantidade de horas trabalhadas por semana. Por esse motivo talvez, quase metade (9/20) dos respondentes do noturno informou, quem sabe de forma equivocada, que trabalha de 8 a 10 horas semanais. Outra evidência da dificuldade em responder às perguntas objetivas apresentadas, foi o tempo gasto para responder ao questionário. Enquanto no turno diurno das duas escolas pesquisadas todo o processo de entrega, resposta e devolução dos questionários levou, em média, 10 minutos, no noturno esse procedimento durou cerca de meia hora.

Posto isso, destaca-se a ressalva de que os dados relativos à carga de trabalho semanal do público discente do noturno podem não corresponder à realidade.

Quadro 34: Carga horária média de trabalho semanal do público discente ativo da escola B, conforme gênero.

\begin{tabular}{|l|c|c|c|c|}
\hline \multicolumn{1}{|c|}{ Escola B } & Média de 10h & Média de 20h & Média de 30h & Média de 40h \\
\hline $\begin{array}{l}\text { Discentes do matutino que } \\
\text { trabalham (86) }\end{array}$ & $11,5 \%$ & $72 \%$ & $11,5 \%$ & $5 \%$ \\
\hline $\begin{array}{l}\text { Discentes do noturno que } \\
\text { trabalham (20) }\end{array}$ & $45 \%$ & $15 \%$ & $10 \%$ & $30 \%$ \\
\hline
\end{tabular}

No Quadro 35, observa-se que, no quesito gênero e jornada de trabalho, das 51 alunas do matutino que trabalham, $80 \%$ trabalha 20 horas semanais. Em relação ao público masculino, dos 35 alunos do matutino que trabalham, 60\% exerce algum ofício 20 horas semanais e $17 \%, 30$ horas semanais. Entre o público que trabalha 40 horas semanais, não houve diferenciação significativa entre os gêneros, $4 \%$ e $6 \%$. 
Quadro 35: Carga horária média de trabalho semanal do público discente do matutino da escola B, conforme gênero.

\begin{tabular}{|l|c|c|c|c|}
\hline $\begin{array}{c}\text { Discentes do matutino } \\
\text { que trabalham }\end{array}$ & Média de 10h & Média de 20h & Média de 30h & Média de 40h \\
\hline Feminino & $8 \%$ & $80 \%$ & $8 \%$ & $4 \%$ \\
\hline Masculino & $17 \%$ & $60 \%$ & $17 \%$ & $6 \%$ \\
\hline
\end{tabular}

Em relação ao público discente da escola B do noturno, das 06 alunas respondentes que trabalham, metade respondeu que trabalha 10 horas semanais. Já entre os alunos, dos 14 respondentes do noturno que trabalham $43 \%$ exercem algum ofício 10 horas semanais e 36\%, 40 horas semanais. Como afirmado anteriormente, tendo em vista a forma com que a questão foi apresentada na pesquisa, quantas horas semanais de trabalho o indivíduo trabalha, talvez tenha confundido muitos alunos a hora de responder.

Quadro 36: Carga horária média de trabalho semanal do público discente do noturno da escola $\mathrm{B}$, conforme gênero.

\begin{tabular}{|l|c|c|c|c|}
\hline $\begin{array}{c}\text { Discentes do noturno } \\
\text { que trabalham }\end{array}$ & Média de 10h & Média de 20h & Média de 30h & Média de 40h \\
\hline Feminino & $50 \%$ & $17 \%$ & $17 \%$ & $17 \%$ \\
\hline Masculino & $43 \%$ & $14 \%$ & $7 \%$ & $36 \%$ \\
\hline
\end{tabular}

No Quadro 37, é possível constatar que conforme o grau de instrução dos estudantes da escola B é maior, aumenta a percentagem de alunos que trabalham. Cabe destacar que das alunas que trabalham: 65\% estão cursando o terceiro ano do Ensino Médio na escola B, no ano de 2016. Entre o público masculino que trabalha, $54 \%$ estão no $3^{\circ}$ ano.

Quadro 37: Porcentagem de ocupação do público discente do matutino da escola B, por série escolar.

\begin{tabular}{|c|c|c|c|c|}
\hline & \multicolumn{2}{|c|}{ Matutino } & \multicolumn{2}{c|}{ Noturno } \\
\hline $\begin{array}{c}\text { Discentes que } \\
\text { trabalham }\end{array}$ & Feminino & Masculino & Feminino & Masculino \\
\hline $1^{\mathrm{o}}$ ano & $14 \%$ & $14 \%$ & $50 \%$ & $29 \%$ \\
\hline $2^{\mathrm{o}}$ ano & $21 \%$ & $32 \%$ & $16 \%$ & $21 \%$ \\
\hline $3^{\mathrm{o}}$ ano & $65 \%$ & $54 \%$ & $34 \%$ & $50 \%$ \\
\hline Total & $100 \%$ & $100 \%$ & $100 \%$ & $100 \%$ \\
\hline
\end{tabular}

No quesito maior grau de instrução dos pais ou responsáveis dos discentes da escola B, cabe destacar que possuem no máximo Ensino Médio incompleto $27 \%$ dos pais do 
turno matutino e 58\%, do noturno. Concluíram o Ensino Médio 28\% dos pais do turno da manhã e $12 \%$, do noturno. Ensino superior, completo e incompleto, praticamente o mesmo percentual em ambos públicos, $16 \%$ e 17\%. Outro dado a ser observado refere-se ao percentual de pais ou responsáveis que estão cursando ou concluíram pós-graduação: $28 \%$ dos genitores do público matutino, e 14\% do noturno.

Com isso, observa-se que, quanto maior a formação dos pais da escola $\mathrm{B}$, maior a tendência do estudante cursar o Ensino Médio no período matutino. E quanto menor a formação, maior a chance de o aluno estudar a noite, conforme apresentado no Quadro 38.

Quadro 38: Formação escolar de pais ou responsáveis do público discente da escola B.

\begin{tabular}{|l|c|c|}
\hline \multicolumn{1}{|c|}{ Formação } & Matutino & Noturno \\
\hline Analfabeto & $0 \%$ & $7 \%$ \\
\hline Fundamental incompleto & $13 \%$ & $21 \%$ \\
\hline Fundamental completo & $5 \%$ & $2 \%$ \\
\hline Ensino Médio incompleto & $9 \%$ & $28 \%$ \\
\hline Ensino Médio completo & $28 \%$ & $12 \%$ \\
\hline Ensino Superior incompleto & $4 \%$ & $5 \%$ \\
\hline Ensino Superior completo & $12 \%$ & $12 \%$ \\
\hline Pós-graduação incompleta & $15 \%$ & $5 \%$ \\
\hline Pós-graduação completa & $13 \%$ & $9 \%$ \\
\hline
\end{tabular}

De acordo com o Quadro 39, em relação aos alunos do matutino que trabalham, é curioso verificar que, ao contrário do que ocorre em relação aos alunos do diurno da escola A, quanto maior a formação dos pais, menor a incidência dos filhos trabalharem. Outra característica interessante a se observar é em relação aos alunos do noturno que não trabalham. Quanto menor o grau de instrução dos pais, maior a porcentagem de filhos que não trabalham $(79 \%)$.

Ainda em comparação com os resultados obtidos em relação aos alunos que trabalham, 46\% dos pais do diurno da escola A possuem até Ensino Médio completo, em contraste com os pais do matutino da escola B que somam $62 \%$ com esse nível de formação. Já em relação aos estudantes que não trabalham, do diurno da escola A $67 \%$ dos pais possuem formação maior que Ensino Médio, já do matutino da escola B soma 46\% nesse nível de escolaridade. 
Quadro 39: Escola B - relação entre formação de pais ou responsáveis e filhos que trabalham.

\begin{tabular}{|c|c|c|c|c|c|c|c|c|}
\hline \multirow{3}{*}{$\begin{array}{l}\text { Formação Pais / Responsáveis } \\
\text { Analfabeto }\end{array}$} & \multicolumn{4}{|c|}{ MATUTINO } & \multicolumn{4}{|c|}{ NOTURNO } \\
\hline & \multicolumn{2}{|c|}{$\begin{array}{l}\text { Porcentagem } \\
\text { filhos que } \\
\text { trabalham } \\
\end{array}$} & \multicolumn{2}{|c|}{$\begin{array}{l}\text { Porcentagem } \\
\text { filhos que } \\
\text { não trabalham } \\
\end{array}$} & \multicolumn{2}{|c|}{$\begin{array}{c}\text { Porcentagem } \\
\text { filhos que } \\
\text { trabalham }\end{array}$} & \multicolumn{2}{|c|}{$\begin{array}{l}\text { Porcentagem } \\
\text { filhos que } \\
\text { não trabalham }\end{array}$} \\
\hline & $0 \%$ & \multirow{5}{*}{$62 \%$} & $0 \%$ & \multirow{5}{*}{$54 \%$} & $10 \%$ & \multirow{5}{*}{$50 \%$} & $0 \%$ & \multirow{5}{*}{$79 \%$} \\
\hline Fundamental incompleto & $16 \%$ & & $12 \%$ & & $5 \%$ & & $29 \%$ & \\
\hline Fundamental completo & $5 \%$ & & $5 \%$ & & $0 \%$ & & $7 \%$ & \\
\hline Ensino Médio incompleto & $10 \%$ & & $9 \%$ & & $30 \%$ & & $21 \%$ & \\
\hline Ensino Médio completo & $31 \%$ & & $27 \%$ & & $5 \%$ & & $21 \%$ & \\
\hline Ensino Superior incompleto & $3 \%$ & \multirow{4}{*}{$38 \%$} & $4 \%$ & \multirow{4}{*}{$46 \%$} & $10 \%$ & \multirow{4}{*}{$50 \%$} & $0 \%$ & \multirow{4}{*}{$21 \%$} \\
\hline Ensino Superior completo & $10 \%$ & & $13 \%$ & & $25 \%$ & & $0 \%$ & \\
\hline Pós-graduação incompleta & $18 \%$ & & $14 \%$ & & $10 \%$ & & $0 \%$ & \\
\hline Pós-graduação completa & $6 \%$ & & $15 \%$ & & $5 \%$ & & $21 \%$ & \\
\hline Total & $100 \%$ & & $100 \%$ & & $100 \%$ & & $100 \%$ & \\
\hline
\end{tabular}

Apresentado o perfil das escolas e das comunidades escolares que responderam à pesquisa, passamos a apresentar os resultados auferidos em relação ao tema qualidade em educação.

\subsection{Educação de qualidade na percepção das comunidades pesquisadas}

(Q1 - docentes e coordenação; Direção Escolar, E1 e E2)

Assim como o tema se apresenta na literatura e em documentos nacionais e internacionais, é possível perceber, na fala dos profissionais que atuam nas duas escolas pesquisadas, diferenciação entre aqueles que enxergam a educação de modo mais amplo e aqueles que compreendem a educação como forma de se alcançar a universidade e de se capacitar para o mercado de trabalho.

Assim sendo, uma parcela compreende educação de qualidade como sendo um meio de se formar cidadãos críticos, conscientes e atuantes no meio onde vivem. Para outros, a educação promovida pela escola deve focalizar o ENEM e o acesso do aluno à universidade, assim como o alcance de metas e indicadores educacionais nacionais propostos. Já um terceiro grupo expôs não um conceito do que se compreende por educação de qualidade, mas os meios e as formas de se melhorar a educação escolar. 
A seguir apresentam-se os resultados dessa questão por público e escola pesquisada.

\title{
Direção da escola A
}

Para a direção da escola A, educação de qualidade é um conceito amplo que vai além de ter o conhecimento das disciplinas:

\begin{abstract}
é uma rede de informação que você tem que dar para o aluno para ele ter aquele conhecimento do básico, [...] dar uma informação precisa, uma informação que ele tire proveito, e uma informação crítica, [...] educação crítica das coisas que a gente tem nesse país, só assim a gente consegue formar o aluno, formar, dar uma cidadania para o aluno, enquanto a gente tiver só dando a informação conceitual das disciplinas, você vai formar só alunos que sabem, que entendem tudo, mas não entende do que está acontecendo no país [...] o aluno ter capacidade de ele pensar, a gente não pode ficar pensando por ele (Direção escola A, E1).
\end{abstract}

\section{Coordenação Pedagógica da Escola A}

Um dos coordenadores pedagógicos entende que "educação de qualidade é evolução cognitiva e progresso social" (Coordenação Pedagógica 1, Escola A).

Os dois coordenadores pedagógicos enfatizaram as condições dos docentes para a oferta de uma educação de melhor qualidade, quais sejam: bom nível de conhecimento e valorização dos profissionais tanto em termos de capacitação quanto em termos de remuneração.

Um deles, em tom de desabafo, salientou que "a escola assume responsabilidades que seriam da família, assim está sobrecarregada. Os problemas sociais estão presentes e cada dia aumentam. O aluno conclui cada etapa de ensino, muitas vezes, sem as competências necessárias. A forma de avaliação não corresponde a realidade" (Coordenação Pedagógica 2, Escola A).

\section{Docentes da Escola A}

Dos treze professores da escola A que participaram da pesquisa, onze responderam à pergunta: $O$ que é educação de qualidade para você? Desses onze, cinco compreendem educação de qualidade no sentido mais amplo: aquela que proporciona as condições adequadas para que se faça o processo de ensino aprendizagem e a formação de um cidadão pleno; observa todos os aspectos de formação humana; transforma os alunos em cidadãos, reflexivos, críticos, questionadores; forma cidadão crítico, ético, com civilidade; espaço de reflexão autônomo que contemple as questões polêmicas da sociedade, respeitando as diversidades e as diferenças (Escola A, docentes: 2, 4, 8, 9 e 10). 
Um docente expressou que educação de qualidade é aquela que prepara o aluno para ingressar em uma universidade ou no mercado de trabalho, seja por meio de concurso ou da iniciativa privada.

Os demais docentes, no entanto, focaram em aspectos relacionados à gestão e às condições de trabalho, tais como: prática de gestão democrática para que haja fortalecimento nos compromissos pedagógicos e no entrosamento entre os profissionais; muita liberdade com as propostas pedagógicas; instalações adequadas, organização e estrutura, boas condições de trabalho com tecnologias, inovação e materiais didáticos de qualidade; formação continuada para os docentes; alunos motivados e com objetivos; coerência entre objetivos e avaliações; ter condições físicas e emocionais de lecionar.

\section{Direção da escola B}

Para a direção da escola B, educação de qualidade depende de muitos fatores, a saber: professores bem remunerados e qualificados; estrutura física adequada; percepção da família sobre educação e principalmente da questão cultural do aluno. Porém, ainda segundo a direção, é possível oferecer uma educação de qualidade "sem nada disso", e exemplificou com escolas do Piauí que não possuem essas condições, mas cujos alunos foram campões da matemática em 2014 e 2015 e obtiveram honra ao mérito. A direção da escola B acredita que educação de qualidade:

perpassa muito mais aquilo que você quer fazer, aquilo que é o seu foco, o seu objetivo para você conseguir matando dez, vinte leões ali por dia [...] você precisa ter motivação, você precisa ter um foco, ter um objetivo para você ter uma educação de qualidade, mas sempre, eu volto a dizer, sem um professor qualificado, bem remunerado, uma parte administrativa e estrutural boa, fica muito difícil, a probabilidade de uma educação de qualidade ela é bem menor. [...] você precisa ter o foco de algo que você quer e aonde você quer chegar, o que você está fazendo aqui, e quem são os seus alunos e do que eles precisam (Direção escola B, E2).

A partir disso, a direção aponta que a abordagem do conhecimento deve ser adequada para cada público atendido, ou seja, como a maior parte dos alunos do matutino visa o ingresso em uma universidade, o foco é o ENEM. Já no noturno (público reduzido composto por apenas 64 alunos do Ensino Médio regular), como há a concentração de alunos com mais idade, com dificuldades maiores e que não almejam o estudo acadêmico, o foco maior é na diminuição das deficiências escolares pregressas e na formação para a vida.

\section{Coordenação Pedagógica da escola B}

Relembrando que, na escola B, para fins dessa pesquisa, computou-se como coordenação pedagógica o coordenador pedagógico propriamente dito do matutino e, do 
noturno, os profissionais que exercem a função de supervisor pedagógico e orientador educacional.

Assim, para um desses profissionais, educação de qualidade é aquela que forma “alunos cidadãos, críticos e conscientes que precisam ver, perceber e transformar a realidade para sempre melhorar a si e sua sociedade" (Coordenação Pedagógica 3, Escola B). E, para isso, aponta que se faz necessário um ensino de qualidade e professores responsáveis e comprometidos com sua função.

Para outro, qualidade na educação é aquela que envolve:

a habilitação técnico-teórica, que valoriza os conhecimentos sistematizados nos livros, apostilas, enfim, durante os anos, décadas e séculos de estudo de outros, mas também que privilegia a socialização, o empreendedorismo, a criatividade, a cultura do nosso país e se possível de outros, a experimentação, que são conhecimentos do currículo oculto [...] complexidade humana, quer no que tange à vida prática, familiar, quanto à acadêmica e profissional dos estudantes (Coordenação Pedagógica 2, Escola B).

Além disso, salienta que se trata da educação que aborda o "contexto mais completo da complexidade humana, quer no que tange à vida prática, familiar, quanto à acadêmica e profissional dos estudantes" (Coordenação Pedagógica 2, Escola B).

Para um profissional que atua com o público do noturno, educação de qualidade:

\begin{abstract}
é aquela que transforma o indivíduo em cidadãos participativos e críticos da e na sociedade onde ele está inserido, assume responsabilidades, desenvolve suas potencialidades, fazendo o melhor em tudo que realiza e ainda promove a melhoria das relações familiares, profissionais e até mesmo filosóficas, políticas e religiosas. Educação de qualidade promove o indivíduo a pensador e transformador $\mathrm{e}$ proporciona meios para melhorar o meio onde o educando convive (Coordenação Pedagógica 1, Escola B).
\end{abstract}

\title{
Docentes Escola B
}

No tocante à percepção dos docentes da escola $\mathrm{B}$, para sete dos quinze que responderam à pesquisa, educação de qualidade é aquela que: ensina o aluno a pensar, refletir sobre sua realidade e lhe dá meios para fazer mudanças significativas no mundo em que vive; relaciona o conhecimento com sua vivência prática social; traz a matéria para o dia-a-dia do aluno; contribui para a formação de um indivíduo autônomo e crítico, capaz de buscar qualidade de vida; ensina valores, prepara para o mundo a enfrentar; desperta, no estudante, a consciência de suas potencialidades; forma para a paz e para o exercício da cidadania, amplia os horizontes em consciência e aceitação da diversidade em todos os níveis, capacita o aluno a exercer sua vida acadêmica e social (Escola B, docentes: 2, 7, 8, 9, 10; 12 e 14).

Para outros quatro docentes da escola $\mathrm{B}$, educação de qualidade é: possibilitar acesso ao conhecimento; ensinar o aluno de forma prática e rápida, facilitando seu raciocínio 
lógico e trazendo a matéria para o seu dia-a-dia; possibilitar o aluno entrar em uma universidade ou fazer boas escolhas profissionais; atender a indicadores educacionais e atingir as metas nacionais propostas (Escola B, docentes: 5, 6, 10 e 13).

Outros quatro focaram em aspectos relacionados aos meios de execução de uma educação de qualidade: exercida de forma compartilhada entre escola, família e Estado, educação de qualidade é aquela que, por meio de ausência de medo, desperta o interesse do aluno em aprender e o estimula a ir para a escola; inclui o estabelecimento de um projeto que consiga aliar professores, alunos, coordenação pedagógica e comunidade escolar, oferecendo o máximo de recursos aos alunos que auxiliem no processo de ensino/aprendizagem. Em termos de ambiente, educação que ofereça boa estrutura, professores capacitados, organização e boa comunicação entre direção, professores, alunos e pais. Compromisso com avaliações bem executadas e bem elaboradas (Escola B, docentes: 1, 3, 4 e 11).

\subsubsection{Relação entre Educação de qualidade e ENEM.}

(Q4 - alunos; Q7 - docentes e coordenação)

O tema ENEM foi tocado na pesquisa de duas maneiras, a saber: de forma espontânea pelos profissionais da educação pesquisados, nas questões abertas; e por meio de uma pergunta fechada aos alunos e semiaberta aos profissionais das escolas, conforme questão a seguir:

- (Q4 - alunos): Do seu ponto de vista, o sucesso dos alunos dessa escola no ENEM (Exame Nacional do Ensino Médio), nos últimos anos, reflete o que é educação de qualidade para você?
( ) não reflete
( ) reflete pouco
( ) reflete
( ) reflete muito

- (Q7 - docentes e coordenação): Do seu ponto de vista, o sucesso dos alunos e da escola no ENEM, nos últimos anos, reflete o que é educação de qualidade para você?

- ( ) não reflete ( ) reflete pouco $\quad($ ) reflete $\quad(\quad)$ reflete muito Por quê?

Salientamos que essa pergunta foi inserida na entrevista à direção escolar, por isso, não constou no questionário aplicado a esse público.

Nos Quadros 40 e 41, apresentam-se as respostas obtidas nas escolas A e B, respectivamente. 
Cabe salientar que, na escola A, essa pergunta contou com a opinião de 336 alunos, 12 docentes (tendo em vista que 01 não repondeu), 02 coordenadores pedagógicos e um diretor escolar da escola $\mathrm{A}$. No tocante à escola $\mathrm{B}$, assinala-se que essa pergunta contou com a opinião de 412 alunos (44 do noturno e 368 do matutino; 15 docentes; 1 coordenador pedagógico, 1 orientador educacional e 1 supervisor pedagógico (lembrando que as respostas do orientador e do supervisor foram consolidadas junto à coordenação perdagógica), além do diretor escolar.

Quadro 40: Percepção da comunidade da Escola A sobre a correlação entre sucesso no ENEM e a qualidade da educação ofertada.

\begin{tabular}{|l|c|c|c|c|}
\hline \multicolumn{1}{|c|}{ Resposta } & Alunos & Docentes & $\begin{array}{c}\text { Coordenação } \\
\text { Pedagógica }\end{array}$ & Direção Escolar \\
\hline não reflete & $8 \%$ & $25 \%$ & $0 \%$ & $0 \%$ \\
\hline reflete pouco & $35 \%$ & $25 \%$ & $100 \%$ & $0 \%$ \\
\hline Reflete & $49 \%$ & $42 \%$ & $0 \%$ & $100 \%$ \\
\hline reflete muito & $7 \%$ & $8 \%$ & $0 \%$ & $0 \%$ \\
\hline
\end{tabular}

Em relação à escola $\mathrm{A}$, de acordo com o Quadro 40, é possível observar que a maior parte da comunidade escolar, incluindo a direção, entende que obter sucesso no ENEM reflete que a escola oferece uma educação de qualidade. Entre os docentes, houve empate, $50 \%$ tem a opinião de que o exame reflete pouco ou não reflete e $50 \%$ entende que reflete ou reflete muito. Apesar disso, o maior número de respostas se deu para a resposta de que o exame reflete uma educação de qualidade. Entre os alunos, houve a mesma tendência dos docentes, pendendo um pouco mais para aqueles que entendem que o ENEM reflete ou reflete muito, com $56 \%$ das respostas. Já os coordenadores pedagógicos têm a percepção de que o exame reflete pouco a qualidade educacional ofertada pela escola.

Quadro 41: Percepção da comunidade da escola B sobre a correlação entre sucesso no ENEM e a qualidade da educação ofertada.

\begin{tabular}{|c|c|c|c|c|c|}
\hline Resposta & $\begin{array}{c}\text { Alunos } \\
\text { Matutino }\end{array}$ & $\begin{array}{c}\text { Alunos } \\
\text { Noturno }\end{array}$ & Docentes & $\begin{array}{c}\text { Coordenação } \\
\text { Pedagógica }\end{array}$ & $\begin{array}{c}\text { Direção } \\
\text { Escolar }\end{array}$ \\
\hline não reflete & $9 \%$ & $2 \%$ & $20 \%$ & $0,0 \%$ & $0 \%$ \\
\hline reflete pouco & $24 \%$ & $32 \%$ & $33 \%$ & $66,7 \%$ & $0 \%$ \\
\hline Reflete & $57 \%$ & $48 \%$ & $47 \%$ & $0,0 \%$ & $0 \%$ \\
\hline reflete muito & $9 \%$ & $18 \%$ & $0 \%$ & $33,3 \%$ & $100 \%$ \\
\hline
\end{tabular}

Em relação à comunidade da escola $\mathrm{B}$, conforme exposto no Quadro 41, cerca da metade dos docentes e dos estudantes tanto do matutino quanto do noturno entendem que o ENEM é reflexo de uma educação de qualidade, mesma tendência de percepção desses 
públicos da escola A. A opinião dos coordenadores pedagógicos de ambas escolas também foi parecida, dos três profissionais da escola $\mathrm{B}$, dois entendem que reflete pouco. $\mathrm{O}$ outro, assim como a direção escolar, considera que reflete muito.

Em relação aos motivos, três docentes da escola A entendem que o sucesso dos alunos no ENEM não reflete a qualidade da educação ofertada em razão do aluno: "Estuda[r] por fora"; "Os que passam é por sorte"; ou reflete pouco porque "Grande parte dos alunos se viram sozinhos!". Verdade ou não, o fato é que a escola A tem estado entre as três primeiras colocadas no ENEM, entre as escolas públicas regulares do DF, pelo menos, nas últimas quatro edições do ENEM (2012 a 2015).

Outros dois professores da escola A entendem que reflete sim, "Por ser um método de avaliação" e "Porque se não houvesse sucesso os alunos não passariam na prova do ENEM". Porém, dois responderam que o sucesso no ENEM se deve, principalmente, ao programa de cotas. Cabe salientar que o sistema de cotas não influi na colocação da escola no ENEM, mas no ingresso do estudante nas unidades federais de ensino superior.

Para um dos coordenadores pedagógicos da escola A: "O ENEM contribui para a progressão dos alunos mas não retrata a realidade e nem a qualidade" (Coordenador 1, Escola A). Para o outro " Os alunos tem acesso às informações dentro e fora da escola. Os alunos que se esforçam se destacam" (Coordenador 2, Escola A).

Entre os docentes da escola B que entendem que obter sucesso no ENEM reflete educação de qualidade, os motivos foram:

- Porque é um índice que ao menos indica um fator avaliativo.

- Pelo desejo de melhorar o estado como nos encontramos. Educação e acomodação não combinam.

- Porque se faz um trabalho visando alcançar essa meta, porém ainda falta muito para ser efetivo.

- O bom desempenho no ENEM nos diz o conhecimento adquirido.

- Reflete, mais para os alunos do diurno.

Para os docentes da escola B que entendem que o ENEM reflete pouco a qualidade da educação, o motivo não deixa de corroborar, de certa forma, com a visão anterior:

- Ainda é só o começo de uma grande jornada, muito a caminhar ainda. 
- Acho que ainda temos muito pela frente, no sentido de preparar o aluno melhor para a vida.

- É apenas uma avaliação. Educação de qualidade vai muito além.

Entre os docentes da escola B que entendem que não reflete, os motivos expostos foram: "A subjetividade na hora de responder ao teste" e porque "O ENEM é um instrumento meramente quantitativo, a prova é fácil e não garante educação de fato". Um docente destacou que reflete pouco porque "Os alunos são adestrados para fazer essas provas".

Na percepção de um dos coordenadores pedagógicos da escola B, para além do ENEM, "é preciso motivar mais os estudantes na busca por uma escolarização melhor, pois o mercado de trabalho exige cada vez mais e as relações interpessoais também". Para outro coordenador, houve a "conjugação de alguns fatores: mudança da clientela, comprometimento da escola com os projetos dos professores e um trabalho coletivo dos professores", o que é positivo, pois demonstra que o ENEM propiciou aos profissionais da escola reflexão em conjunto sobre um objetivo comum. Estimulou a reorganização dos trabalhos e a aproximação dos docentes de áreas distintas, parte, talvez, em função da interdisciplinaridade das questões. Dessa forma, dentro de suas limitações, e para além de seu papel, talvez o ENEM tenha criado um norte a ser alcançado pela equipe.

$\mathrm{Na}$ visão da direção da escola $\mathrm{B}$, reflete muito porque trata-se de um exame de Ensino Médio pelo qual é possível mensurar a educação dos alunos. Em relação ao salto dado pela escola B entre as edições do ENEM 2013 e 2014 (cerca de 15 posições), a direção credita ao trabalho realizado de estudo do ENEM desde quando assumiu a gestão em 2012 (vide item 1.2.1) e, em grande parte, ao empenho do coordenador pedagógico a época, o qual ministrou aos docentes, o curso promovido pelo MEC sobre Ensino Médio, incluído no PNEM.

Por fim, cabe salientar que o intuito de se questionar aos profissionais da educação se o sucesso no ENEM retrataria uma educação de qualidade para eles, foi simplesmente verificar o foco dos burocratas na ponta, responsáveis pela implementação da política educacional. Como se pode constatar na exposição de motivos, há a compreensão de que o ENEM é um importante instrumento avaliativo, que ao menos sinaliza o estado como a educação daquela unidade escolar se encontra. Porém, para a maioria dos profissionais de ambas as escolas, a educação de qualidade vai muito além do sucesso no ENEM, deve visar a formação para a vida. 
4.2.2. Formação integral do indivíduo - áreas a serem aperfeiçoadas nas escolas pesquisadas (Q3 - Alunos; Q6 - Docentes e Coordenação; Q1 - Direção).

Com base na visão de uma formação integral do indivíduo (o que inclui o desenvolvimento de competências para o trabalho e para o exercício da cidadania) e a partir de temas da atualidade, foi elaborada uma questão de múltipla escolha, aplicada a todos os participantes. Nela os respondentes puderam escolher mais de uma opção. O intuito foi buscar descobrir possíveis demandas da comunidade escolar, assim como sinalizações para o alcance de uma educação de melhor qualidade. Adaptado o enunciado da questão ao público respondente, a pergunta foi (as opções de respostas estão apresentadas no Quadro 42):

- (Q3-Alunos) Com vistas a uma melhor formação, marque as áreas abaixo que você gostaria que a escola explorasse mais ou promovesse atividades extracurriculares (pode marcar mais de 1 vez):

- (Q6 - Docentes e Coordenação e Q1- Direção) Com vistas à melhoria da qualidade da educação ofertada, marque abaixo as áreas que deveriam ser enfatizadas ou promovidas atividades extracurriculares na escola:

Salienta-se que, na escola A, essa pergunta contou com a opinião de 337 alunos, 11 docentes (tendo em vista que 02 não reponderam), 02 coordenadores pedagógicos e o diretor escolar da escola A. Esclarece-se que a opinião da direção não foi inserida no Gráfico 5, porém, consta na Quadro 42.

Em relação à escola $\mathrm{B}$, essa pergunta contou com a opinião de 413 alunos, 15 docentes, 3 coordenadores pedagógicos e o diretor da escola B. Ainda que, no gráfico polar, haja um peso maior às opiniões dos coordenadores, na prática esse ponto de vista pode ter mais ou menos peso a depender do grau de convencimento junto aos professores e à direção. Como ocorreu anteriormente, a opinião da direção da escola B não foi inserida no Gráfico 6, porém, consta na Quadro 42. Dessa forma, com os resultados elaboraram-se os Gráficos 5 e 6 e Quadro 42, apresentados a seguir. 
Gráfico 5: Áreas que deveriam ser enfatizadas na escola A na percepção de docentes, coordenação pedagógica e estudantes.

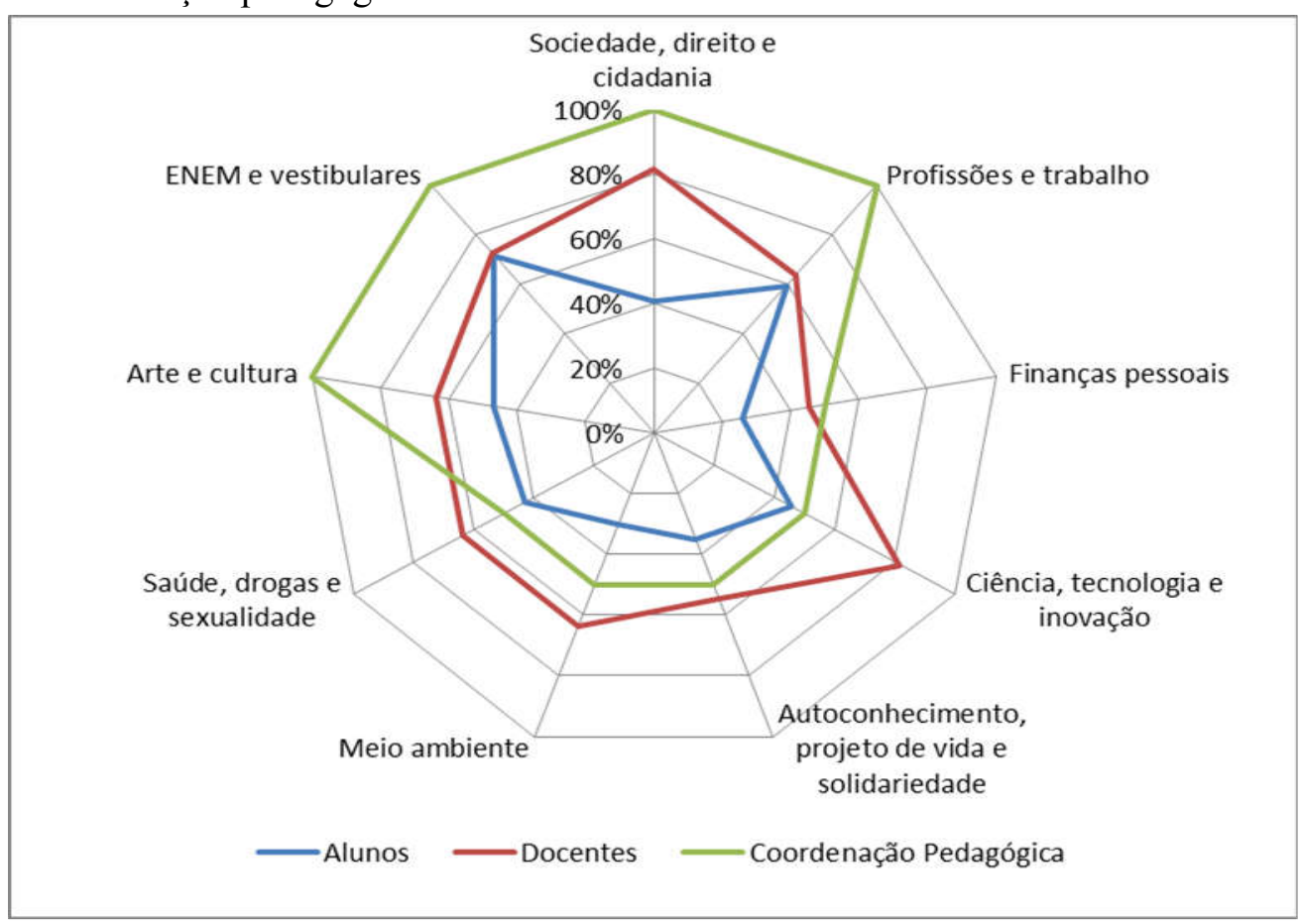

Gráfico 6: Áreas que deveriam ser enfatizadas na escola B na percepção de docentes, coordenação pedagógica e estudantes.

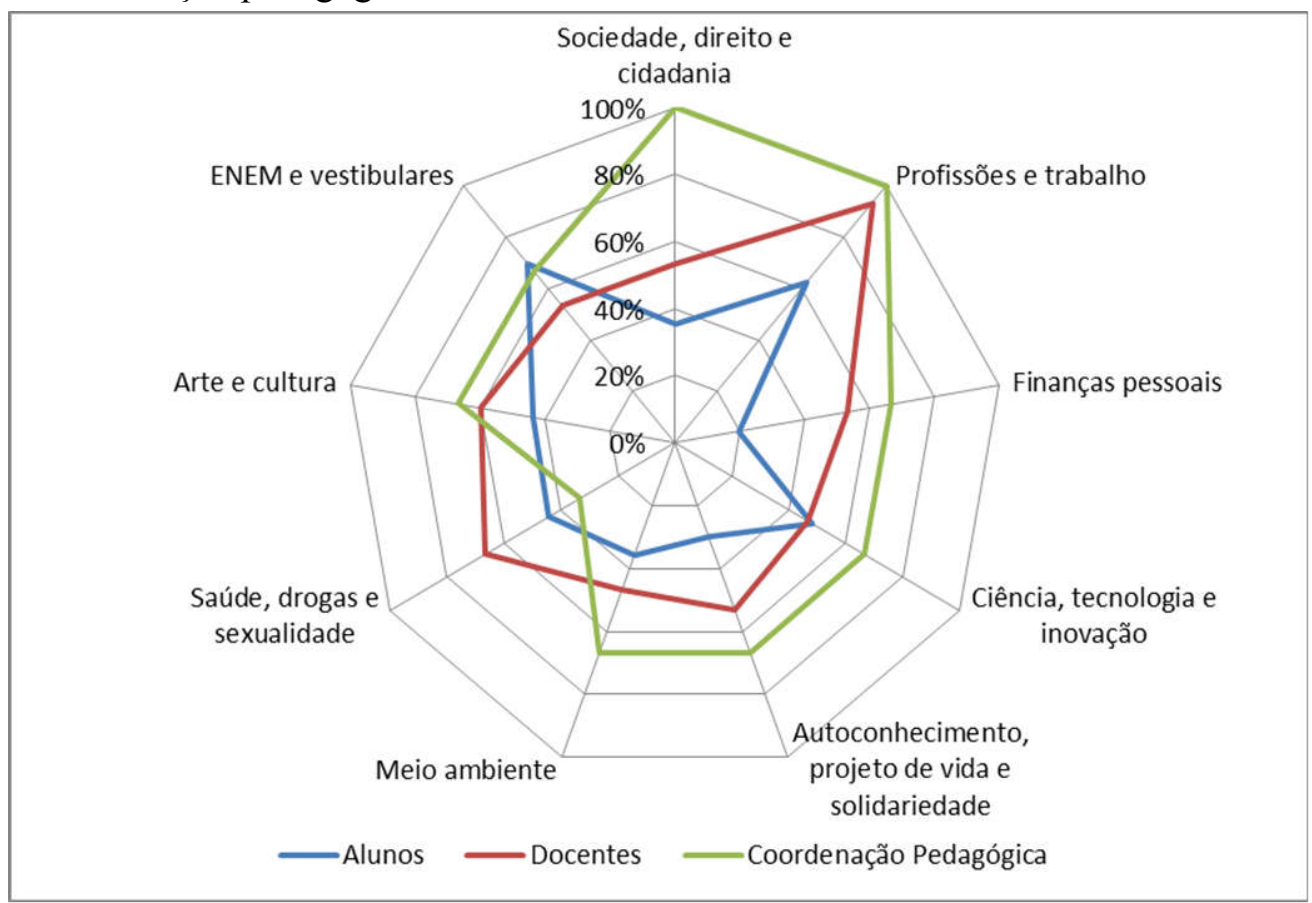


Quadro 42: Áreas que deveriam ser enfatizadas na percepção das comunidades da Escola A e da Escola B.

\begin{tabular}{|c|c|c|c|c|c|c|c|c|c|}
\hline \multirow[b]{2}{*}{ Item } & \multirow[b]{2}{*}{ Área } & \multicolumn{4}{|c|}{ ESCOLA A } & \multicolumn{4}{|c|}{ ESCOLA B } \\
\hline & & Alunos & Docentes & $\begin{array}{l}\text { Coordenação } \\
\text { Pedagógica }\end{array}$ & $\begin{array}{l}\text { Direção } \\
\text { Escolar }\end{array}$ & Alunos & Docentes & $\begin{array}{l}\text { Coordenação } \\
\text { Pedagógica }\end{array}$ & $\begin{array}{l}\text { Direção } \\
\text { Escolar }\end{array}$ \\
\hline 1 & $\begin{array}{l}\text { Sociedade, direito e cidadania (estudo e } \\
\text { resolução de problemas do cotidiano e do } \\
\text { entorno da escola) }\end{array}$ & $41 \%$ & $82 \%$ & $100 \%$ & $100 \%$ & $35 \%$ & $53 \%$ & $100 \%$ & $0 \%$ \\
\hline 2 & Profissões e trabalho & $60 \%$ & $64 \%$ & $100 \%$ & $100 \%$ & $62 \%$ & $93 \%$ & $100 \%$ & $100 \%$ \\
\hline 3 & Finanças pessoais e orçamento doméstico & $26 \%$ & $46 \%$ & $50 \%$ & $100 \%$ & $20 \%$ & $53 \%$ & $67 \%$ & $0 \%$ \\
\hline 4 & Ciência, tecnologia e inovação & $46 \%$ & $82 \%$ & $50 \%$ & $100 \%$ & $48 \%$ & $47 \%$ & $67 \%$ & $100 \%$ \\
\hline 5 & $\begin{array}{l}\text { Autoconhecimento, projeto de vida e } \\
\text { solidariedade }\end{array}$ & $35 \%$ & $55 \%$ & $50 \%$ & $0 \%$ & $30 \%$ & $53 \%$ & $67 \%$ & $0 \%$ \\
\hline 6 & Meio ambiente e sustentabilidade ambiental & $30 \%$ & $64 \%$ & $50 \%$ & $100 \%$ & $36 \%$ & $47 \%$ & $67 \%$ & $100 \%$ \\
\hline 7 & Saúde, drogas e sexualidade & $43 \%$ & $64 \%$ & $50 \%$ & $100 \%$ & $44 \%$ & $67 \%$ & $33 \%$ & $0 \%$ \\
\hline 8 & Arte e cultura & $47 \%$ & $64 \%$ & $100 \%$ & $100 \%$ & $44 \%$ & $60 \%$ & $67 \%$ & $100 \%$ \\
\hline 9 & ENEM e vestibulares & $72 \%$ & $73 \%$ & $100 \%$ & $0 \%$ & $70 \%$ & $53 \%$ & $67 \%$ & $100 \%$ \\
\hline 10 & Outros. Quais?* & - & $15 \%$ & $0 \%$ & $0 \%$ & - & $0 \%$ & $67 \%$ & $0 \%$ \\
\hline
\end{tabular}

*Esse item não foi aplicado aos alunos. 
$\mathrm{Na}$ visão da direção da escola $\mathrm{A}$, somente os temas "autoconhecimento, projeto de vida e solidariedade" e "ENEM e vestibulares" não precisariam ser enfatizados na escola, todas as demais sim. O segundo tema, ENEM, de acordo com a entrevista não precisaria, em virtude de já ser bastante trabalhado na escola, motivo pelo qual não haveria a necessidade de se enfatizá-la ainda mais.

Por sua vez, na percepção da direção da escola B, além do tema "ENEM e vestibulares", deveriam ser enfatizados na escola: "Profissões e trabalho"; "Ciência, tecnologia e inovação"; "Meio ambiente e sustentabilidade ambiental" e "Arte e cultura", áreas também apontados pela direção da escola $\mathrm{A}$.

Destaca-se que houve alinhamento de percerções entre os alunos da escola A e os da escola B. A porcentagem de respostas para cada item foi muito próxima entre os dois públicos, o que indica que há uma concordância de opinião entre os jovens de ambas as escolas. Para os alunos das escolas A e B, os dois temas que mais deveriam ser enfatizados nas respectivas escolas foram "ENEM e vestibulares", com 70\% das respostas, e "Profissões e trabalho", opção de $60 \%$ do alunado, o que demonstra foco na continuidade dos estudos escolares e a necessidade de definição de profissão e trabalho, inerente a essa fase de vida.

Curioso verificar que, áreas de certo modo relacionadas, como "Autoconhecimento, projeto de vida e solidariedade" e "Finanças pessoais e orçamento doméstico", foram os itens que menos indicações receberam, entre $20 \%$ e $30 \%$ dos estudantes de ambas as escolas. Este último, finanças e orçamento doméstico, talvez, por não ser, ainda, uma demanda real do público em questão no momento.

O tema "Profissões e trabalho" também foi o item mais indicações pelos profissionais escolares de ambas as escolas: diretores, coordenadores pedagógicos e 93\% dos docentes da escola B. "ENEM e vestibulares" também foi considerado importante pela maioria dos profissionais.

Outra área bastante indicada pelos profissionais foi "Sociedade, direito e cidadania (estudo e resolução de problemas do cotidiano e do entorno da escola", opção de $100 \%$ das coordenações pedagógicas, da direção da escola A e de $82 \%$ dos docentes da escola A. Porém, pouco escolhida pelos alunos de ambas as escolas, média de $38 \%$.

Outro tema bastante escolhido pelos docentes da escola A foi "Ciencia, tecnologia e inovação", opção de $82 \%$ deles e de ambas as direções escolares. Porém, indicado por cerca da metade dos alunos e dos demais profissionais.

Em relação a "Meio ambiente e sustentabilidade ambiental", indicado pelos diretores; pela maioria dos coordenadores e por $64 \%$ dos docentes da escola $\mathrm{A}$, foi apontado 
por apenas um terço dos alunos em geral e por metade dos professores da escola B. Cabe observar que o tema já é bastante trabalhado na escola $\mathrm{A}$, a qual oferece atividades como: Oficina de Meio Ambiente; horta vertical e horizontal; isolamento térmico de salas com embalagens Tetrapak; reúso da água de chuva, todas com participação dos estudantes. Talvez por esse motivo apenas $30 \%$ dos alunos da escola entenda que é necessário ainda mais atividades extras nesse tema.

No tocante a "Saúde, drogas e sexualidade", aproximadamente metade dos alunos e $65 \%$ dos docentes, de ambas as escolas, assim como a direção da escola A, entendem a necessidade de atividades extracurriculares nas respectivas unidades. No entanto, essa não foi opção da maioria dos coordenadores, nem da direção da escola B. Isso sugere que os docentes, provavelmente pelo maior contato que possuem com os alunos, estejam percebendo essa necessidade mais do que os coordenadores e o dirigente.

No quesito "Arte e Cultura", é curioso que as equipes profissionais demandaram mais do que os próprios alunos. Indicado por $47 \%$ e por $45 \%$ dos estudantes das escolas A e $\mathrm{B}$, respectivamente.

Em relação ao item 10, aberto para os profissionais indicarem outras áreas não contempladas na questão, que eles entendam ser relevantes para a melhoria da qualidade educacional, da escola A apenas dois docentes acrescentaram: "Esportes, questões ligadas à diversidade etc" e "PAS, concursos". Da escola B, apenas os coordenadores indicaram "Prática esportivas, aulas de música, teatro" e "Política Pública, Sustentabilidade ambiental e humana, diversidade". Dessas áreas, apenas esporte e diversidade não haviam sido contempladas diretamente na questão.

Com foco na formação integral do indivíduo, buscou-se verificar, também, ainda que de forma incipiente, se aspectos da educação socioemocional, apontada pela literatura e em evento de políticas públicas mais recente (ABED, 2014; FÓRUM INTERNACIONAL, 2014), estão sendo trabalhados, na prática, nas escolas A e B. Para isso, formulou-se o item 5 da questão anterior analisada ("Autoconhecimento, projeto de vida e solidariedade") e a seguinte pergunta, adaptado o enunciado e ampliada, conforme o público:

- (Q2 - Alunos) Em sua opinião, a escola tem lhe estimulado a perseguir um futuro melhor, a superar desafios, a ser perseverante nos seus objetivos, cooperativo, criativo, inovador?
( ) nunca
( ) raramente ( ) as vezes
( ) frequentemente
( ) sempre 
- (Q5 - Docentes e Coordenação) Em sua opinião, a escola tem estimulado o aluno a perseguir um futuro melhor, a superar desafios, a ser perseverante nos seus objetivos, cooperativo, criativo, inovador?
( ) nunca
( ) raramente
( ) as vezes
( ) frequentemente
( ) sempre
De que forma?

Em relação à percepção das comunidades escolares sobre a necessidade de reforço ou promoção de atividades extracurriculares sobre as áreas: autoconhecimento, projeto de vida e solidariedade (item 5 do Quadro 42), verificou-se baixa demanda pelos temas, tanto por parte dos estudantes quanto dos profissionais escolares, conforme se pode constatar no Quadro 43.

Quadro 43: Percepção das comunidades escolares sobre a necessidade de reforço ou promoção de atividades extracurriculares sobre os temas: autoconhecimento, projeto de vida e solidariedade.

\begin{tabular}{|c|c|c|c|c|c|c|c|}
\hline \multicolumn{3}{|c|}{ ESCOLA A } & \multicolumn{4}{c|}{ ESCOLA B } \\
\hline Alunos & Docentes & $\begin{array}{c}\text { Coordenação } \\
\text { Pedagógica }\end{array}$ & $\begin{array}{c}\text { Direção } \\
\text { Escolar }\end{array}$ & Alunos & Docentes & $\begin{array}{c}\text { Coordenação } \\
\text { Pedagógica }\end{array}$ & $\begin{array}{c}\text { Direção } \\
\text { Escolar }\end{array}$ \\
\hline $35 \%$ & $55 \%$ & $50 \%$ & $0 \%$ & $30 \%$ & $53 \%$ & $67 \%$ & $0 \%$ \\
\hline
\end{tabular}

Apesar de ambas comunidades escolares terem destacado a importância de se trabalhar mais os temas "profissões e trabalho" (item 2, Quadro 42), os quesitos "autoconhecimento e projeto de vida" receberam baixa indicação, alvo de um terço do alunado, de pouco mais da metade do professorado e da coordenação pedagógica, e preterido pelas direções.

A partir desses dados, pode-se depreender que grande parte dos estudantes analisados não atrela os temas profissão e trabalho a projeto de vida. Também não considera a importância de melhor se autoconhecer para a definição de seu futuro profissional.

Em relação à questão relativa à opinião do respondente sobre a escola incentivar o estudante a perseguir um futuro melhor, a superar desafios, a ser perseverante em seus objetivos, cooperativo, criativo, inovador, ambos os diretores compreendem que as respectivas escolas tem sempre encorajado o estudante nesse sentido. Para os coordenadores pedagógicos, a quem cabe o papel de orientar os docentes nesse sentido, a resposta variou entre as unidades de ensino. $\mathrm{Na}$ escola $\mathrm{A}$, os coordenadores entendem que os alunos são frequentemente ou sempre incentivados. $\mathrm{Na}$ escola $\mathrm{B}$, a maior parte desses profissionais 
disseram que essa prática é realizada às vezes; um deles entende que sempre são encorajados. No Quadro 44 apresenta-se um resumo das respostas sobre essa questão.

Quadro 44: Regularidade com que a escola incentiva os alunos a buscar um futuro melhor, superar desafios, ser perseverante nos seus objetivos, cooperativo, criativo, inovador, na percepção das comunidades escolares.

\begin{tabular}{|c|c|c|c|c|c|c|}
\hline & PÚBLICO & Nunca & Raramente & Às vezes & Frequentemente & Sempre \\
\hline \multirow{4}{*}{ 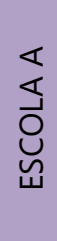 } & Direção & $0 \%$ & $0 \%$ & $0 \%$ & $0 \%$ & $100 \%$ \\
\hline & Coordenadores & $0 \%$ & $0 \%$ & $0 \%$ & $50 \%$ & $50 \%$ \\
\hline & Docentes & $0 \%$ & $8 \%$ & $33 \%$ & $25 \%$ & $33 \%$ \\
\hline & Alunos & $2 \%$ & $8 \%$ & $39 \%$ & $38 \%$ & $14 \%$ \\
\hline \multirow{4}{*}{ 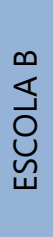 } & Direção & $0 \%$ & $0 \%$ & $0 \%$ & $0 \%$ & $100 \%$ \\
\hline & Coordenadores & $0 \%$ & $0 \%$ & $67 \%$ & $0 \%$ & $33 \%$ \\
\hline & Docentes & $0 \%$ & $13 \%$ & $27 \%$ & $33 \%$ & $27 \%$ \\
\hline & Alunos & $3 \%$ & $9 \%$ & $37 \%$ & $31 \%$ & $20 \%$ \\
\hline
\end{tabular}

Em análise aos dados, de modo geral, 50\% dos estudantes de ambas as escolas sentem que são incentivados frequentemente ou sempre a perseguirem um futuro melhor, a superar desafios, a ser perseverante nos seus objetivos, cooperativo, criativo, inovador. Nesse sentido, opinaram cerca de $60 \%$ dos docentes de ambas as escolas, além de $100 \%$ dos coordenadores da escola A. Encorajados às vezes, a média geral dos estudantes foi de $38 \%$.

Com intuito de aperfeiçoar a análise pelo ponto de vista dos estudantes, elaboraram-se os Quadros 45 e 46. Com isso, buscou-se averiguar se haveria diferença de percepção entre os públicos feminino e masculino ou entre os alunos do $1^{\circ}, 2^{\circ}$ e $3^{\circ}$ anos. Como se pode observar nos quadros, houve certo equilíbrio nas respostas.

Quadro 45: Regularidade com que a escola A incentiva os alunos, na percepção dos estudantes, por gênero e série.

\begin{tabular}{|c|c|c|c|c|c|}
\hline Gênero & Nunca & Raramente & as vezes & frequentemente & sempre \\
\hline Feminino & $2 \%$ & $5 \%$ & $37 \%$ & $41 \%$ & $15 \%$ \\
\hline Masculino & $3 \%$ & $11 \%$ & $40 \%$ & $34 \%$ & $12 \%$ \\
\hline Série & Nunca & Raramente & as vezes & frequentemente & sempre \\
\hline $1^{\circ}$ ano & $4 \%$ & $11 \%$ & $36 \%$ & $36 \%$ & $14 \%$ \\
\hline $2^{\circ}$ ano & $3 \%$ & $7 \%$ & $32 \%$ & $39 \%$ & $20 \%$ \\
\hline $3^{\circ}$ ano & $1 \%$ & $5 \%$ & $48 \%$ & $38 \%$ & $9 \%$ \\
\hline
\end{tabular}


Quadro 46: Regularidade com que a escola B incentiva os alunos, na percepção dos estudantes, por gênero e série.

\begin{tabular}{|c|c|c|c|c|c|}
\hline Gênero & Nunca & Raramente & as vezes & frequentemente & sempre \\
\hline Feminino & $3 \%$ & $9 \%$ & $31 \%$ & $32 \%$ & $25 \%$ \\
\hline Masculino & $2 \%$ & $8 \%$ & $46 \%$ & $29 \%$ & $15 \%$ \\
\hline Série & Nunca & Raramente & as vezes & frequentemente & sempre \\
\hline $1^{\circ}$ ano & $1 \%$ & $7 \%$ & $33 \%$ & $31 \%$ & $28 \%$ \\
\hline $2^{\circ}$ ano & $7 \%$ & $7 \%$ & $46 \%$ & $30 \%$ & $11 \%$ \\
\hline $3^{\circ}$ ano & $2 \%$ & $12 \%$ & $34 \%$ & $31 \%$ & $21 \%$ \\
\hline
\end{tabular}

Em relação ao gênero, percebe-se a mesma tendência de entendimento entre os públicos respectivos. $\mathrm{Na}$ opinião de $55 \%$ das alunas de ambas as escolas, elas tem sido incentivadas frequentemente ou sempre na escola a perseguirem um futuro melhor; percepção de $45 \%$ do público masculino das escolas A e B.

Já no tocante à etapa serial, cerca de $40 \%$ dos alunos tanto do $1^{\circ}$ ano quanto do $2^{\circ}$ e do $3^{\circ}$ anos, sinalizaram que são frequentemente estimulados na escola A. Nesse sentido, responderam 30\% dos alunos da escola B. Sentem-se incentivados pela escola B sempre, cerca de $20 \%$ dos estudantes do $1^{\circ}$ ano e $30 \%$ do $3^{\circ}$ ano. Percepção também de $20 \%$ dos alunos do segundo ano da escola A.

Entre as formas com que a escola tem incentivado os alunos, de acordo com os profissionais da escola A, estão: projetos, palestras, oficinas, debates, pesquisas, conversas, orientação, vídeos, participando de concurso/olimpíadas, eventos culturais, incentivando o aluno a fazer cursos, estágio.

Cabe observar que a proximidade de localização das escolas com entidades do poder público federal propicia a troca de informações e experiências com os alunos, como se pode verificar nos seguintes relatos de dois docentes da escola A:

- "Criando espaços de protagonismo juvenil, realizando projetos interdisciplinares, convênios com o PIBID, com a UnB";

- "Palestras com pessoas de outras instituições como: universidade, exército e TCU”.

Segundo os profissionais da escola B, o incentivo se dá por meio de: conversas; palestras motivadoras e sobre profissões; exposições relativas ao mercado de trabalho e oportunidades; oficinas, passeios culturais extracurriculares, incentivando o aluno a escrever, raciocinar e lutar pelos seus sonhos; por meio de projetos pedagógicos que estimulam a 
participação e o desempenho dos alunos, tais como teatro, Noite de Talentos, Sarau, Oficina de Poesia e Feiras Culturais; passeios culturais a exposições; propondo atividades que levem o aluno a conviver com a realidade social, econômica e política do país, pesquisas de campo e leitura de livros. De acordo com uma coordenadora do noturno, o incentivo é dado quando:

\begin{abstract}
a orientadora [educacional da escola] faz palestras sobre o mercado de trabalho, currículo vitae, entrevista, por exemplo, faculta-lhe na preparação para aquisição do primeiro emprego; [...] quando se faz palestras sobre direito trabalhista, contextualiza a percepção de seu estado atual como profissional que poderá levar o estudante a procurar algo melhor e que atenda às suas necessidades e direitos renegados inicialmente no emprego em que está, pode auxiliar na mudança de atitude; [...] quando se faz, juntamente com os estudantes, a inscrição para provas como o ENEM, PAS, participar de concursos escolares, isso valoriza a autoestima dos estudantes bem como gera a expectativa de qualidade de vida futura (Q5 Coordenadora B).
\end{abstract}

Desse modo, foi possível constatar que as formas utilizadas por ambas as escolas para encorajar os alunos são semelhantes: conversas, palestras, eventos, parcerias. Algo que pode fazer diferença ao aluno e que não depende de recurso financeiro propriamente dito.

\title{
4.3. Análise por categoria
}

Nessa seção, serão analisados os resultados da pesquisa a partir das categorias elencadas, quais sejam: ambiente educativo/clima organizacional; prática pedagógica; avaliação do estudante e reforço escolar; gestão escolar; formação e condições de trabalho dos docentes e ambiente físico escolar (infraestrutura e recursos escolares).

Observa-se que, tendo em vista uma das questões aplicadas englobar todas as categorias elencadas, optou-se por apresentar primeiramente os Gráficos 7 e 8 e o Quadro 47 referente à esta questão, contendo os resultados auferidos na pesquisa. As análises estão dispostas na sequência, conforme a categoria correspondente. A questão em pauta é:

- (Q5-Alunos; Q8 - Docentes e Coordenação e Q2- Direção) Em sua opinião, o que precisa ser feito para melhorar a qualidade do Ensino Médio nessa escola? (pode marcar mais de uma vez).

Os itens-resposta de múltipla escolha estão expressos na legenda dos referidos Gráficos, na página a seguir, e no Quadro 47.

Ademais, salienta-se que além dessa questão, outras foram utilizadas para a análise das categorias, assim como as entrevistas com os dirigentes escolares. Tais aspectos 
foram indicados logo abaixo de cada categoria. Como exemplo, a categoria "ambiente educativo/clima organizacional" foi analisado a partir das questões 1 e 5 do questionário aplicado aos alunos; questões 4 e 8 do aplicado aos docentes e coordenadores pedagógicos e questão 2 realizada ao dirigente escolar. Essa indicação foi sintetizada da seguinte forma: Q1 e Q5 - alunos; Q4 e Q8 - docentes e coordenação; Q2 - Direção.

É fundamental destacar que ao se perguntar (em diversas questões aplicadas) o que precisaria ser feito para a melhoria da qualidade da educação, não se procurou tratar o tema de forma linear, incomplexa, creditando o problema ou a "solução" a uma área ou público específico, ou a uma ação simplista. Pelo contrário, buscou-se propiciar uma visão do todo para se tentar compreender a realidade na ponta e, a partir daí, possibilitar reflexões e subsídios para a pesquisa e, consequentemente, para gestores da política educacional.

Esclarece-se que essa questão foi adaptada e ampliada nos questionários aplicados aos profissionais escolares nos seguintes itens:

( ) Melhorar o Projeto Político Pedagógico da escola.

( ) Melhorar a implementação do Projeto Político Pedagógico.

( ) Melhorar a infraestrutura da escola. Em que aspecto?

( ) Outras sugestões:

Da mesma forma como se apresentou a questão anterior, a opinião da direção não foi inserida nos Gráficos 7 e 8, porém, consta no Quadro 47.

Do ponto de vista geral, observa-se que houve grande alinhamento de percepção entre os estudantes de ambas as escolas em relação ao que precisaria ser feito para melhorar a qualidade do Ensino Médio. O item mais apontado foi em relação à necessidade de se desenvolver aulas mais estimulantes e interativas.

Entre os docentes da escola $\mathrm{A}$ e da escola $\mathrm{B}$, a sintonia maior se deu em relação à necessidade de se aperfeiçoar o material de ensino e aprendizagem, visão corroborada pelos dirigentes de ambas as escolas. Ainda sob o prisma das direções escolares, houve concordância em relação à necessidade de se aprimorar: a infraestrutura escolar; a formação docente; a avaliação e o reforço escolar; e espaços para se discutir regras de disciplina e encaminhamentos.

A seguir, apresentam-se os Gráficos 7 e 8 e o Quadro 47, e, na sequência, as análises por categoria. 
Gráfico 7: O que precisa ser feito para melhorar a qualidade do Ensino Médio na escola A na percepção de estudantes, docentes e coordenação pedagógica.

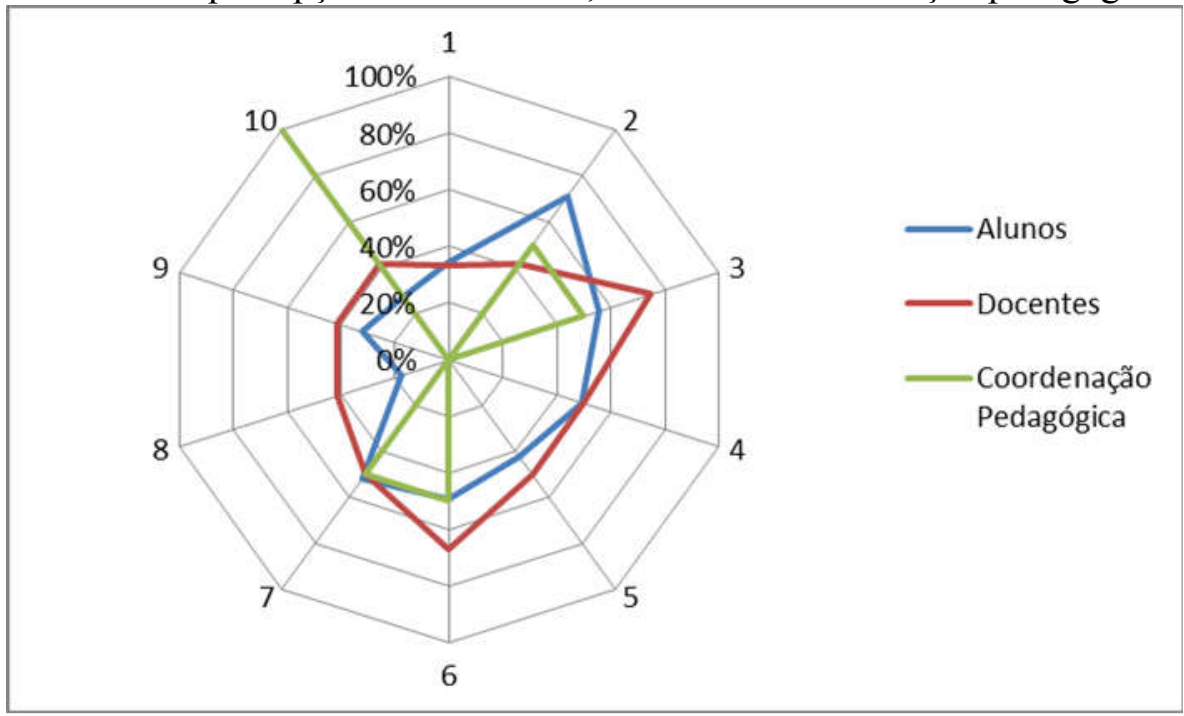

Gráfico 8: O que precisa ser feito para melhorar a qualidade do Ensino Médio na escola B na percepção de estudantes, docentes e coordenação pedagógica.

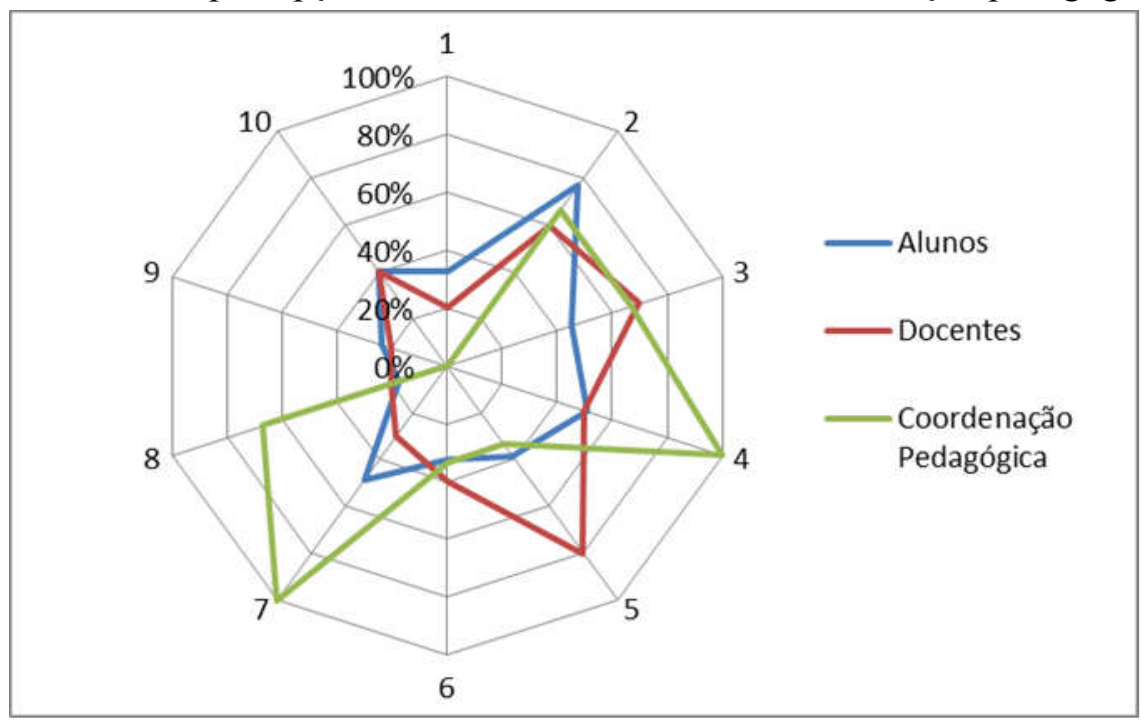

Legenda:

1. Promover um ambiente educativo mais acolhedor, que favoreça o bom relacionamento entre todos.

2. Desenvolver aulas mais estimulantes e interativas.

3. Aperfeiçoar o material de ensino e aprendizagem, incluindo o uso de jogos, softwares educativos, vídeos e internet.

4. Criar espaços onde os alunos possam discutir, contribuir e negociar formas para melhor aprender o conteúdo.

5. Criar espaços onde todos (alunos, direção, professores, funcionários e pais ou responsáveis) possam discutir e negociar as regras de disciplina e encaminhamentos relativos ao andamento da escola.

6. Melhorar a forma de avaliação dos alunos (provas, seminários, pesquisas, elaboração de vídeos etc).

7. Promover ou aperfeiçoar o reforço escolar para os alunos com nota baixa.

8. Melhorar a formação dos docentes.

9. Melhorar a gestão escolar.

10. Melhorar a infraestrutura física da escola (salas de aula, biblioteca, laboratórios, quadra de esporte etc). 
Quadro 47: O que precisa ser feito para melhorar a qualidade do Ensino Médio na percepção das comunidades das escolas A e B.

\begin{tabular}{|c|c|c|c|c|c|c|c|c|c|}
\hline \multirow[b]{2}{*}{ Item } & \multirow[b]{2}{*}{ Ações } & \multicolumn{4}{|c|}{ ESCOLA A } & \multicolumn{4}{|c|}{ ESCOLA B } \\
\hline & & Alunos & Docentes & $\begin{array}{c}\text { Coordenação } \\
\text { Pedagógica } \\
\end{array}$ & $\begin{array}{l}\text { Direção } \\
\text { Escolar }\end{array}$ & Alunos & Docentes & $\begin{array}{c}\text { Coordenação } \\
\text { Pedagógica }\end{array}$ & $\begin{array}{l}\text { Direção } \\
\text { Escolar }\end{array}$ \\
\hline 1 & $\begin{array}{l}\text { Promover um ambiente educativo mais acolhedor, } \\
\text { que favoreça o bom relacionamento entre todos. }\end{array}$ & $34 \%$ & $33 \%$ & $0 \%$ & $0 \%$ & $33 \%$ & $20 \%$ & $0 \%$ & $0 \%$ \\
\hline 2 & Desenvolver aulas mais estimulantes e interativas. & $71 \%$ & $42 \%$ & $50 \%$ & $0 \%$ & $77 \%$ & $60 \%$ & $67 \%$ & $100 \%$ \\
\hline 3 & $\begin{array}{l}\text { Aperfeiçoar o material de ensino e aprendizagem, } \\
\text { incluindo o uso de jogos, softwares educativos, } \\
\text { vídeos e internet. }\end{array}$ & $56 \%$ & $75 \%$ & $50 \%$ & $100 \%$ & $45 \%$ & $70 \%$ & $67 \%$ & $100 \%$ \\
\hline 4 & $\begin{array}{l}\text { Criar espaços onde os alunos possam discutir, } \\
\text { contribuir e negociar formas para melhor aprender } \\
\text { o conteúdo. }\end{array}$ & $49 \%$ & $50 \%$ & $0 \%$ & $0 \%$ & $51 \%$ & $50 \%$ & $100 \%$ & $0 \%$ \\
\hline 5 & $\begin{array}{l}\text { Criar espaços onde todos (alunos, direção, } \\
\text { professores, funcionários e pais ou responsáveis) } \\
\text { possam discutir e negociar as regras de disciplina e } \\
\text { encaminhamentos relativos ao andamento da } \\
\text { escola. }\end{array}$ & $42 \%$ & $50 \%$ & $0 \%$ & $100 \%$ & $38 \%$ & $80 \%$ & $33 \%$ & $100 \%$ \\
\hline 6 & $\begin{array}{l}\text { Melhorar a forma de avaliação dos alunos (provas, } \\
\text { seminários, pesquisas, elaboração de vídeos etc). }\end{array}$ & $49 \%$ & $67 \%$ & $50 \%$ & $100 \%$ & $32 \%$ & $40 \%$ & $33 \%$ & $100 \%$ \\
\hline 7 & $\begin{array}{l}\text { Promover ou aperfeiçoar o reforço escolar para os } \\
\text { alunos com nota baixa. }\end{array}$ & $52 \%$ & $50 \%$ & $50 \%$ & $100 \%$ & $49 \%$ & $30 \%$ & $100 \%$ & $100 \%$ \\
\hline 8 & Melhorar a formação dos docentes. & $18 \%$ & $42 \%$ & $0 \%$ & $100 \%$ & $17 \%$ & $20 \%$ & $67 \%$ & $100 \%$ \\
\hline 9 & Melhorar a gestão escolar. & $32 \%$ & $42 \%$ & $0 \%$ & $100 \%$ & $24 \%$ & $20 \%$ & $0 \%$ & $0 \%$ \\
\hline 10 & $\begin{array}{l}\text { Melhorar a infraestrutura física da escola (salas de } \\
\text { aula, biblioteca, laboratórios, quadra de esporte etc). }\end{array}$ & $28 \%$ & $42 \%$ & $100 \%$ & $100 \%$ & $41 \%$ & $40 \%$ & $0 \%$ & $100 \%$ \\
\hline$*$ & Melhorar o Projeto Político Pedagógico da escola & - & $17 \%$ & $0 \%$ & $100 \%$ & - & $10 \%$ & $33 \%$ & $0 \%$ \\
\hline$*$ & $\begin{array}{l}\text { Melhorar a implementação do Projeto Político } \\
\text { Pedagógico }\end{array}$ & - & $\begin{array}{l}33 \% 4 / 13 \\
\text { docentes }\end{array}$ & $100 \%$ & $100 \%$ & - & $50 \%$ & $67 \%$ & $0 \%$ \\
\hline
\end{tabular}

*Itens não aplicados ao público discente, por isso não constam nos Gráficos 7 e 8. 


\subsubsection{Ambiente educativo/clima organizacional}

$$
\text { (Q1 e Q5 - alunos; Q4 e Q8 - docentes e coordenação; Q2 - Direção) }
$$

De modo geral, as comunidades de ambas as escolas avaliaram o ambiente escolar acolhedor e que favorece o bom relacionamento entre todos. Para os dirigentes escolares e os coordenadores pedagógicos, o ambiente educativo está adequado e propicia o bom relacionamento entre todos. Visão corroborada por quase $70 \%$ dos estudantes de ambas as escolas, assim como por cerca de $70 \%$ dos docentes da escola A e $80 \%$, da escola B, conforme apresentado no Quadro 48.

Quadro 48: Percepção das comunidades escolares sobre a necessidade de se promover um ambiente educativo mais acolhedor, que favoreça o bom relacionamento entre todos.

\begin{tabular}{|c|c|c|c|c|c|c|c|}
\hline \multicolumn{4}{|c|}{ ESCOLA A } & \multicolumn{4}{c|}{ ESCOLA B } \\
\hline Alunos & Docentes & $\begin{array}{c}\text { Coordenação } \\
\text { Pedagógica }\end{array}$ & $\begin{array}{c}\text { Direção } \\
\text { Escolar }\end{array}$ & Alunos & Docentes & $\begin{array}{c}\text { Coordenação } \\
\text { Pedagógica }\end{array}$ & $\begin{array}{c}\text { Direção } \\
\text { Escolar }\end{array}$ \\
\hline $34 \%$ & $33 \%$ & $0 \%$ & $0 \%$ & $33 \%$ & $20 \%$ & $0 \%$ & $0 \%$ \\
\hline
\end{tabular}

\section{Escola A}

Em relação à escola $\mathrm{A}$, conforme se pode observar no Quadro 47, esse item (Q8, item 1) foi o que menos indicações recebeu dos públicos docente e discente da escola A, opção de cerca de 35\% dos respondentes. Também não foi apontado pela coordenação pedagógica nem pela direção. O que indica que o clima organizacional na escola A do ponto de vista geral é bom.

Essa constatação pode ser confirmada quando $71 \%$ dos alunos se dizem satisfeitos ou muito satisfeitos com a qualidade do ensino oferecido pela escola A. Em termos de gênero, não houve diferenciação significativa entre os públicos feminino e masculino, conforme se pode observar no Quadro 49.

Quadro 49: Grau de satisfação dos estudantes com a qualidade do ensino ofertado pela escola A, geral e por gênero.

\begin{tabular}{|c|c|c|c|c|c|}
\hline Estudantes & $\begin{array}{c}\text { Muito } \\
\text { insatisfeito }\end{array}$ & Insatisfeito & $\begin{array}{c}\text { Nem satisfeito } \\
\text { nem insatisfeito }\end{array}$ & Satisfeito & $\begin{array}{c}\text { Muito } \\
\text { satisfeito }\end{array}$ \\
\hline Geral & $1 \%$ & $8 \%$ & $20 \%$ & $61 \%$ & $10 \%$ \\
\hline Feminino & $1 \%$ & $8 \%$ & $21 \%$ & $60 \%$ & $11 \%$ \\
\hline Masculino & $1 \%$ & $7 \%$ & $19 \%$ & $64 \%$ & $10 \%$ \\
\hline
\end{tabular}


Segundo a direção da escola A (E1), o clima organizacional da escola é muito bom, porém, não dá pra generalizar.

Em relação aos profissionais escolares, expressaram que gostam de trabalhar na escola A: a direção, os coordenadores pedagógicos e $72 \%$ dos professores, conforme Quadro 50. Dos 11 professores que responderam a questão, um deles havia entrado na escola fazia dois dias, por isso não se posicionou; um se disse indiferente, pois gosta do trabalho como professor; outro expressou "Sim e não; gestão arbitrária; relações de trabalho".

Quadro 50: Gostam de trabalhar na escola A

\begin{tabular}{|c|c|c|}
\hline Docentes & Coordenação Pedagógica & Direção \\
\hline $72 \%$ & $100 \%$ & $100 \%$ \\
\hline
\end{tabular}

A direção disse que gosta muito de trabalhar na escola A porque possui vínculo com ela, fez estágio nela na década de 1980 e sempre quis voltar a trabalhar nela. Os coordenadores pedagógicos expuseram que gostam de trabalhar na escola A porque essa possui boa estrutura física; bons gestores; valoriza o profissional, a coordenação e o planejamento interdisciplinar. É uma escola de projetos. Por isso, para um dos coordenadores o que precisa ser melhorado é a avaliação; já o outro apontou a necessidade de mais verbas para o desenvolvimento de projetos pedagógicos, demanda apontada também por um dos docentes.

Entre os motivos expressos pelos docentes por gostarem de trabalhar na escola A, estão: ambiente agradável; boa relação entre os professores; pelo respeito à diversidade e o comprometimento da equipe; alunos, na maioria, interessados e compromissados; por gostar de dar aula e por poder fazer a diferença para alguns estudantes.

Já em relação ao que poderia ser melhorado, foram apontadas questões relacionadas a planejamento, aumento de recursos financeiros, comunicação e relacionamento entre gestores e demais profissionais, conforme exposto:

- Planejamento prévio! Foco nos projetos e atividades como feiras.

- Poderiam aumentar as verbas para projetos pedagógicos.

- Precisa melhorar o relacionamento entre os gestores e professores/servidores/ funcionários, assédio moral nas relações. Deve haver respeito nas relações tanto em grupos, como pessoalmente.

- A melhoria poderia ser pela comunicação entre escola/professor/aluno. 
- A presença firme da direção, na mediação dos problemas relacionados a comportamentos e posturas dos alunos, torna essa escola um ambiente não só agradável quanto mais salubre de se trabalhar.

Dessa forma, entre os docentes, um expôs a necessidade de melhoria na comunicação e outro no relacionamento entre gestores e os demais profissionais da escola, apontando, inclusive, questão de assédio moral nas relações, expondo a necessidade de respeito nas relações tanto em grupo, como pessoalmente. Outro professor, por sua vez, elogiou a postura firme da direção na mediação dos problemas relacionados aos alunos, salientando que esta torna o ambiente agradável e mais salubre para se trabalhar. Um dos docentes expressou incômodo em relação a "professores acomodados e um sistema paternalista com alunos e servidores".

De acordo com o que a pesquisadora pode observar, tanto os profissionais como os alunos têm livre acesso ao dirigente escolar, inclusive ficam muito à vontade em chamar a direção pelo nome (sem pronome de tratamento) o que sugere abertura e aproximação. Fato esse, inclusive, constatado e comentado pela pesquisadora durante a entrevista.

De toda forma, para o estudo retêm-se a importância do diálogo e da boa comunicação entre os membros da comunidade, assim como o inter-relacionamento respeitoso para a melhoria da qualidade educacional.

\section{Escola B}

No quesito ambiente escolar, a comunidade da escola B avaliou como sendo adequado, sem necessidade de aperfeiçoamento. Entendimento da direção, dos coordenadores, de quase $70 \%$ do alunado e $80 \%$ do corpo docente. O que indica que o clima organizacional na escola B do ponto de vista geral é bom.

Em relação aos estudantes, essa constatação pode ser confirmada ao analisar o grau de satisfação desses com a qualidade do ensino oferecido pela escola B. Expressaram satisfação com a educação ofertada 56\% do alunado, e muito satisfeitos, 7,5\%. Em relação ao gênero, não houve diferenciação significativa de opinião entre os públicos feminino e masculino, permanecendo a mesma tendência, conforme Quadro 51. 
Quadro 51: Grau de satisfação dos estudantes com a qualidade do ensino ofertado pela escola $\mathrm{B}$, geral e por gênero.

\begin{tabular}{|c|c|c|c|c|c|}
\hline Estudantes & $\begin{array}{c}\text { Muito } \\
\text { insatisfeito }\end{array}$ & Insatisfeito & $\begin{array}{c}\text { Nem satisfeito } \\
\text { nem insatisfeito }\end{array}$ & Satisfeito & $\begin{array}{c}\text { Muito } \\
\text { satisfeito }\end{array}$ \\
\hline Geral & $3 \%$ & $7,5 \%$ & $26 \%$ & $56 \%$ & $7,5 \%$ \\
\hline Feminino & $2 \%$ & $7 \%$ & $29 \%$ & $56 \%$ & $7 \%$ \\
\hline Masculino & $5 \%$ & $8 \%$ & $23 \%$ & $56 \%$ & $7 \%$ \\
\hline
\end{tabular}

Do ponto de vista dos profissionais escolares, houve maior alinhamento de percepção sobre o ambiente educativo/clima organizacional, como se pode observar no Quadro 52.

Quadro 52: Gostam de trabalhar na escola B.

\begin{tabular}{|c|c|c|}
\hline Docentes & Coordenação Pedagógica & Direção \\
\hline $100 \%$ & $100 \%$ & $100 \%$ \\
\hline
\end{tabular}

Cabe destacar que além de $100 \%$ da equipe profissional gostar de trabalhar na escola B, 5 dos 15 professores respondentes expressaram que gostam muito de trabalhar na escola. Um deles enfatizou, ainda, que "a escola é excepcional”. Entre os motivos expostos estão: a boa comunicação entre toda a comunidade escolar; boa estrutura física e de recursos para as aulas; e o fato de ser pequena facilita um trabalho com maior profundidade. Porém, duas principais razões foram destacadas: a clientela e a equipe profissional da escola. Quatro docentes relataram que a clientela é boa, os alunos são respeitosos; e nove professores ressaltaram a qualidade da equipe: homogênea, comprometida, dedicada, que visa sempre o melhor para o aluno, como expresso a seguir:

- A escola é excepcional, e o que mais motiva é justamente a experiência e o comprometimento de toda a equipe pedagógica;

- Sim, pois há de fato uma intencionalidade na busca pelo progresso e excelência;

- Os profissionais aqui buscam uma escola de qualidade;

- O compromisso da escola e do corpo docente em querer melhorar o processo de ensino/aprendizagem, buscando alternativas para que os alunos [do noturno] se sintam 'capazes de';

- Equipe de professores homogênea;

- Ótima equipe de trabalho;

- A qualidade e comprometimento da equipe docente; 
- Profissionais comprometidos com a educação [...] a vontade de estar sempre buscando o melhor para os alunos;

- Existe boa interação entre os servidores.

Já os coordenadores pedagógicos expuseram que a motivação de trabalhar na escola B se dá "em ver nossos alunos alcançando a aprendizagem e procuro despertar neles o desejo de crescer como cidadãos responsáveis". Para outro a razão principal é “a clientela atendida, que é carente e um pouco mais adulta no turno que trabalho - noturno -, a liberdade de atuação na minha área [...], o cuidado da equipe diretiva, bem como de estudantes e professores com a instituição, que é arborizada, limpa, equipada e cuidada por todos". De acordo com o outro coordenador, a motivação vem de "aperfeiçoar e corrigir, melhorar cada dia mais a escola, a administração, a pessoa".

Já no tocante ao que poderia ser melhorado, apenas quatro docentes sinalizaram opções. Três, no mesmo sentido, indicaram "meios tecnológicos para ampliar e melhorar o ensino-aprendizagem"; "colocar recursos tecnológicos em cada sala de aula"; "infraestrutura e material de apoio, com sala de recursos multimídia de qualidade para exibição de vídeos, filmes, documentários". Um quarto docente indicou a necessidade de se "dar mais liberdade aos alunos".

Como sugestão de melhoria, um dos coordenadores entende que se poderia implantar um "projeto de prática esportiva que consiga conciliar os estudos dos conteúdos diversos, com a prática esportiva supervisionada, aumentaria o interesse de os alunos estarem em suas escolas; Motivar os professores a se comprometer em tornar a escola agradável”. 


\subsubsection{Prática pedagógica}

(Q2; Q3 e Q5 - alunos; Q6 e Q8 - docentes e coordenação; Q1 e Q2 - Direção)

Quadro 53: Percepção das comunidades escolares sobre aspectos pedagógicos.

\begin{tabular}{|l|c|c|c|c|c|c|c|c|}
\hline \multicolumn{1}{|c|}{ Ações } & Alunos & Docentes & $\begin{array}{c}\text { Coordenação } \\
\text { Pedagógica }\end{array}$ & $\begin{array}{c}\text { Direção } \\
\text { Escolar }\end{array}$ & Alunos & Docentes & $\begin{array}{c}\text { Coordenação } \\
\text { Pedagógica }\end{array}$ & $\begin{array}{c}\text { Direção } \\
\text { Escolar }\end{array}$ \\
\hline Melhorar o PPP* & - & $17 \%$ & $0 \%$ & $100 \%$ & - & $10 \%$ & $33 \%$ & $0 \%$ \\
\hline $\begin{array}{l}\text { Melhorar a } \\
\text { implementação } \\
\text { do PPP* }\end{array}$ & - & $33 \%$ & $100 \%$ & $100 \%$ & - & $50 \%$ & $67 \%$ & $0 \%$ \\
\hline $\begin{array}{l}\text { Aulas mais } \\
\text { estimulantes }\end{array}$ & $71 \%$ & $42 \%$ & $50 \%$ & $0 \%$ & $77 \%$ & $60 \%$ & $67 \%$ & $100 \%$ \\
\hline $\begin{array}{l}\text { Aperfeiçoar o } \\
\text { material de } \\
\text { ensino }\end{array}$ & $56 \%$ & $75 \%$ & $50 \%$ & $100 \%$ & $45 \%$ & $70 \%$ & $67 \%$ & $100 \%$ \\
\hline $\begin{array}{l}\text { Criar espaços } \\
\text { para se discutir } \\
\text { formas para } \\
\text { melhor } \\
\text { aprender }\end{array}$ & $49 \%$ & $50 \%$ & $0 \%$ & $0 \%$ & $51 \%$ & $50 \%$ & $100 \%$ & $0 \%$ \\
\hline
\end{tabular}

*Itens não aplicados ao público discente.

\section{Escola A}

No tocante ao PPP da escola A, observa-se que há concordância entre a coordenação pedagógica e $83 \%$ dos docentes, de que o projeto está adequado. Porém, para a coordenação e um terço dos professores, bem como para a direção, a implementação do PPP precisa ser aperfeiçoada.

$\mathrm{Na}$ visão dos estudantes, a demanda mais apontada, com 71\% das indicações, se refere à necessidade de se "desenvolver aulas mais estimulantes e interativas". Nesse aspecto, apenas um dos coordenadores pedagógicos e $42 \%$ dos docentes apontaram esse item como uma área a ser aperfeiçoada. Esse cenário indica um ponto de dissonância entre as visões dos profissionais da área e o público foco do serviço. Isso demonstra que parte da coordenação e a maior parte dos docentes não entende que as aulas precisam ser aperfeiçoadas, o que é um problema, pois compete a eles tornar as aulas mais cativantes.

Apesar disso, essa discordância de entendimento pode ser em razão do foco diferenciado dado sobre o assunto, pois $75 \%$ dos docentes da escola A apontaram que é preciso "aperfeiçoar o material de ensino e aprendizagem, incluindo o uso de jogos, softwares educativos, vídeos e internet" (item 3), o que talvez corrobore para tornar as aulas mais 
estimulantes, como demandam os alunos. Esse item foi indicado por $56 \%$ dos estudantes, pela direção escolar e por um coordenador pedagógico.

Uma forma de se alinhar demandas e expectativas, no caso, apontado no item 4 da questão, seria a escola criar espaços onde os alunos possam discutir, contribuir e negociar formas para melhor aprender o conteúdo. Nesse sentido, 50\% dos alunos e dos docentes concordam que a abertura desse canal melhoraria a qualidade do ensino. Visão não corroborada pela coordenação, nem pela direção escolar.

\section{Escola B}

Em relação ao PPP da escola B, observa-se também concordância entre a maior parte dos profissionais: direção, dois terços da coordenação pedagógica e 90\% dos docentes, de que o projeto pedagógico da escola está adequado. Porém, a sua implementação precisa ser aperfeiçoada na visão de 50\% dos docentes e para dois dos três coordenadores respondentes.

Do ponto de vista estudantil, assim como os alunos da escola A demandaram, $77 \%$ dos alunos da escola B apontaram necessidade de se desenvolver aulas mais estimulantes e interativas. Visão alinhada com $60 \%$ dos docentes, por dois terços da coordenação pedagógica e pela direção escolar. Em relação à necessidade de aperfeiçoamento do material de ensino e aprendizagem, apesar de 55\% dos estudantes não apontarem esse item como algo a ser aperfeiçoado, entre os profissionais foi elencado por cerca de $70 \%$ dos docentes e da coordenação, assim como pela direção da escola B.

A proposta de se criar espaços onde os alunos possam discutir, contribuir e negociar formas para melhor aprender o conteúdo foi apoiada pela coordenação pedagógica, porém, demadada por apenas metade dos públicos discente e docente da escola B.

Em resumo, do ponto de vista dos estudantes de ambas as escolas, o quesito mais requerido, em média por $75 \%$ do alunado, foi a necessidade de se desenvolver aulas mais interativas e estimulantes. Porém, $50 \%$ deles não demandam espaços onde possam discutir e contribuir para atingir esse objetivo. Já o aspecto mais apontado pelos docentes da escola A, e segundo mais demandado pelos docentes da escola B, foi o aperfeiçoamento do material de ensino aprendizagem. Visão das direções escolares e de três dos cinco coordenadores pedagógicos participantes da pesquisa. 


\subsubsection{Avaliação do estudante e reforço escolar}

$$
\text { (Q5, itens } 6 \text { e } 7 \text { - alunos; Q8, itens } 8 \text { e } 9 \text { - docentes e coordenação) }
$$

Quadro 54: Percepção das comunidades escolares no tocante à necessidade de melhoria da forma avaliativa dos alunos e do reforço escolar.

\begin{tabular}{|c|c|c|c|c|c|c|c|c|}
\hline & \multicolumn{4}{|c|}{ ESCOLA A } & \multicolumn{4}{c|}{ ESCOLA B } \\
\hline Item & Alunos & Docentes & $\begin{array}{c}\text { Coordenação } \\
\text { Pedagógica }\end{array}$ & $\begin{array}{c}\text { Direção } \\
\text { Escolar }\end{array}$ & Alunos & Docentes & $\begin{array}{c}\text { Coordenação } \\
\text { Pedagógica }\end{array}$ & $\begin{array}{c}\text { Direção } \\
\text { Escolar }\end{array}$ \\
\hline 6 & $49 \%$ & $67 \%$ & $50 \%$ & $100 \%$ & $32 \%$ & $40 \%$ & $33 \%$ & $100 \%$ \\
\hline 7 & $52 \%$ & $50 \%$ & $50 \%$ & $100 \%$ & $49 \%$ & $30 \%$ & $100 \%$ & $100 \%$ \\
\hline
\end{tabular}

Legenda:

Item 6. Melhorar a forma de avaliação dos alunos (provas, seminários, pesquisas, elaboração de vídeos etc). Item 7. Promover ou aperfeiçoar o reforço escolar para os alunos com nota baixa.

Em relação à avaliação e ao reforço escolar, para a direção da escola A é preciso aperfeiçoar ambas as práticas, ainda que a escola às vezes disponibiliza monitorias de algumas matérias no contraturno das aulas por meio de parceria, conforme informou o dirigente. Visão corroborada por metade dos demais profissionais da escola A. Segundo a direção, o professor não quer dar o reforço, e "muitas vezes ele não está errado, ele fala assim, [...] eu não vou fazer reforço com aluno que na minha aula ele não presta atenção, como é que que eu vou fazer reforço com ele? (Direção Escola A, E1).

Conforme se pode observar no Quadro 54, apenas o quesito "melhorar a forma de avaliação dos alunos", foi apontado como necessário por cerca de $70 \%$ dos docentes da escola A. Apesar da direção da escola B compreender que se faz necessário melhorar a prática avaliativa dos alunos, apenas um terço dos alunos e da coordenação pedagógica da escola B corroboram nesse sentido. Entre os docentes da escola B, somam 40\%. Em relação à necessidade de aperfeiçoamento do reforço escolar, demanda de $50 \%$ dos estudantes da escola $\mathrm{B}$, houve alinhamento de percepção entre a direção e a coordenação pedagógica. Porém, visão confirmada por apenas $30 \%$ dos docentes que participaram da pesquisa.

Dessa forma, para metade dos estudantes de ambas as escolas pesquisadas há a necessidade de ações voltadas para reforço escolar (item 7). Ponto de vista dos diretores de ambas as escolas e da coordenadenação pedagógica da escola B. 


\subsubsection{Gestão escolar}

(Q5 - Alunos; Q8 - Docentes e Coordenação; Q2 - Direção)

Quadro 55: Percepção das comunidades escolares no tocante à necessidade de melhoria da gestão e de criação de espaços de discussão sobre regras de disciplina e encaminhamentos.

\begin{tabular}{|l|c|c|c|c|c|c|c|c|}
\hline \multicolumn{1}{|c|}{ Ações } & \multicolumn{3}{|c|}{ ESCOLA A } & \multicolumn{4}{c|}{ ESCOLA B } \\
\hline $\begin{array}{l}\text { Melhorar a gestão } \\
\text { escolar (item 9) }\end{array}$ & $32 \%$ & $42 \%$ & $0 \%$ & $100 \%$ & $24 \%$ & $20 \%$ & $0 \%$ & $0 \%$ \\
\hline $\begin{array}{l}\text { Criar espaços onde } \\
\text { todos possam } \\
\text { discutir sobre regras } \\
\text { de disciplina e } \\
\text { encaminhamentos } \\
\text { (item 5). }\end{array}$ & $42 \%$ & $50 \%$ & $0 \%$ & $100 \%$ & $38 \%$ & $80 \%$ & $33 \%$ & $100 \%$ \\
\hline
\end{tabular}

Legenda: Item 5. Criar espaços onde todos (alunos, direção, professores, funcionários e pais ou responsáveis) possam discutir e negociar as regras de disciplina e encaminhamentos relativos ao andamento da escola.

Conforme dados apresentados no Quadro 55, em relação à gestão da escola A, $42 \%$ dos docentes, um terço dos alunos e a própria direção escolar percebem que há espaço para melhoria da gestão.

No tocante à necessidade de se criar espaços onde todos (alunos, direção, professores, funcionários e pais ou responsáveis) possam discutir e negociar as regras de disciplina e encaminhamentos relativos ao andamento da escola (item 5), apoiado pela direção escolar, houve a indicação de $42 \%$ dos alunos e de $50 \%$ dos professores da escola A. Percepção não corroborada pela pela coordenação pedagógica.

Já em relação à escola $\mathrm{B}$, apenas um quarto dos alunos e um quinto dos docentes visualizam a necessidade de melhoria da gestão escolar. No tocante à necessidade de se criar espaços onde todos possam discutir, contribuir e negociar regras de disciplina e encaminhamentos da escola, apesar da direção ter indicado essa necessiade, segundo ela, na escola B: "há espaço em que todos falam da regra de disciplina, eu vou para a sala de aula, lemos o Manual de Alunos, todo ano" (Direção Escola B, E2).

De acordo com a direção da escola B, desde a chegada dela na escola, em 2002, já havia o manual do estudante, o qual vem sendo aperfeiçoado. Apesar desse diálogo com os estudantes, parece que os docentes demandam esse espaço, pois esse foi o aspecto que mais indicação teve entre os professores da escola $\mathrm{B}$, apontado $80 \%$ do público docente e por um terço da coordenação pedagógica, assim como demandada por $40 \%$ dos alunos. 
4.3.5. Formação e condições de trabalho dos docentes

(Q5 - Alunos; Q4, Q8 - Docentes e Coordenação; Q2 - Direção )

Quadro 56: Percepção das comunidades escolares no tocante à necessidade de melhoria da formação docente.

\begin{tabular}{|c|c|c|c|c|c|c|c|c|}
\hline & \multicolumn{5}{|c|}{ ESCOLA A } & \multicolumn{3}{c|}{ ESCOLA B } \\
\hline Ações & Alunos & Docentes & $\begin{array}{c}\text { Coordenação } \\
\text { Pedagógica }\end{array}$ & $\begin{array}{c}\text { Direção } \\
\text { Escolar }\end{array}$ & Alunos & Docentes & $\begin{array}{c}\text { Coordenação } \\
\text { Pedagógica }\end{array}$ & $\begin{array}{c}\text { Direção } \\
\text { Escolar }\end{array}$ \\
\hline $\begin{array}{l}\text { Melhorar a } \\
\text { formação dos } \\
\text { docentes } \\
\text { (item 8). }\end{array}$ & $18 \%$ & $42 \%$ & $0 \%$ & $100 \%$ & $17 \%$ & $20 \%$ & $67 \%$ & $100 \%$ \\
\hline
\end{tabular}

Com Índice de Adequação da Formação Docente em torno de 70\%, em ambas as escolas de acordo com resultados do ENEM 2015 (INEP, 2016b), a demanda por melhoria na formação docente foi a mais baixa entre os alunos das duas escolas, 17 \% e 18\%, conforme se pode observar no Quadro 56.

Em relação à opinião dos profisssionais da escola $\mathrm{A}$, a melhoria na formação docente foi indicada apenas pelo dirigente e por $42 \%$ dos professores. No tocante à escola $\mathrm{B}$, apontada pela direção e por dois terços da coordenação pedagógica, foi preterida por $80 \%$ do professorado.

No tocante às condições de trabalho na escola $\mathrm{B}$, segundo o depoimento de um docente é possível verificar que são adequadas:

Pelo menos nessa escola, vejo que isso não é problema, pois encontro profissionais extremamente comprometidos, com vasta experiência na área, inclusive professores com mestrado e doutorado, além de um suporte no que diz respeito a tecnologias voltadas para o processo de ensino/aprendizagem, sem esquecer da interação entre corpo docente e coordenação pedagógica (Q2 - Docente B).

Em termos de condições de trabalho, os principais aspectos apontados foram: melhoria do ambiente tecnológico das escolas; acesso à internet com alta velocidade que possibilite atender uma turma inteira; material didático; recursos para o desenvolvimento de oficinas ou projetos; além da necessidade de se disponibilizar acesso à terapia psicológica aos docentes. 


\subsubsection{Ambiente físico escolar (infraestrutura e recursos escolares)}

(Q5 - alunos; Q8 - docentes e coordenação)

Quadro 57: Percepção das comunidades escolares no tocante à necessidade de melhoria do material de ensino e da infraestrutura escolar.

\begin{tabular}{|c|c|c|c|c|c|c|c|c|}
\hline & \multicolumn{4}{|c|}{ ESCOLA A } & \multicolumn{4}{c|}{ ESCOLA B } \\
\hline Ações & Alunos & Docentes & $\begin{array}{c}\text { Coordenação } \\
\text { Pedagógica }\end{array}$ & $\begin{array}{c}\text { Direção } \\
\text { Escolar }\end{array}$ & Alunos & Docentes & $\begin{array}{c}\text { Coordenação } \\
\text { Pedagógica }\end{array}$ & $\begin{array}{c}\text { Direção } \\
\text { Escolar }\end{array}$ \\
\hline $\begin{array}{c}\text { Aperfeiçoar o } \\
\text { material de ensino }\end{array}$ & $56 \%$ & $75 \%$ & $50 \%$ & $100 \%$ & $45 \%$ & $70 \%$ & $67 \%$ & $100 \%$ \\
\hline $\begin{array}{c}\text { Melhorar a } \\
\text { infraestrutura }\end{array}$ & $28 \%$ & $42 \%$ & $100 \%$ & $100 \%$ & $41 \%$ & $40 \%$ & $0 \%$ & $100 \%$ \\
\hline
\end{tabular}

\section{Escola A}

Em relação à infraestrutura da escola A (item 10), conforme exposto no Quadro $57,28 \%$ dos estudantes, $42 \%$ dos professores e os dois coordenadores pedagógicos indicam a necessidade de se melhorar a infraestrutura física da escola (salas de aula, biblioteca, laboratórios, quadra de esporte etc). Apesar de o item ter sido aberto aos profissionais da escola poderem apontar em que aspecto a infraestrutura precisaria ser aperfeiçoada, apenas um coordenador apontou a necessidade de se "ter mais espaços físicos e equipamentos". E dois docentes manifestaram: um a carência de se ter mais profissionais e o outro a necessidade de conserto dos ventiladores devido as salas serem muito quentes.

Segundo a direção da escola $\mathrm{A}$, há necessidade de melhoria na acessibilidade tanto dentro da escola A como na área externa limítrofe (calçadas e ruas); construção de um auditório para apresentações e reuniões mais amplas, pois a maior sala na escola comporta no máximo 70 pessoas; assim como carência de mais um coordenador pedagógico e de supervisor para intermediar questões administrativas junto à comunidade escolar.

No campo "Outras sugestões", aberto a todos os profissionais, a direção da escola A incluiu a necessidade de se "aumentar o valor da verba encaminhada à escola". Para os professores, é preciso: aumentar o número de profissionais, visão corroborada por um dos coordenadores "ter servidores específicos $\mathrm{p}$ / os laboratórios, ter + coordenadores, supervisores pedagógicos, etc"; resolver o problema das salas muito quentes, consertando os ventiladores e "criar no aluno o desejo de estudar, aprender, ouvir, respeitar etc. Trazer a família de volta à escola”. Para o coordenador pedagógico, além de mais profissionais, é preciso "internet, melhorar o laboratório (de informática)". A questão da baixa velocidade da internet, que impossibilita o docente trabalhar com a turma no laboratório de informática, foi enfatizada em entrevista pela direção escolar. 
Assim, na escola A tanto a direção como um coordenador e dois docentes apontaram a necessidade de mais profissionais no quadro escolar, seja para coordenação, supervisão, seja para aulas em laboratórios e a disponibilização de internet com maior velocidade de modo que se possa atender uma turma inteira no laboratório.

Em relação ao item "aperfeiçoar o material de ensino e aprendizagem, incluindo o uso de jogos, softwares educativos, vídeos e internet", 75\% dos docentes e a direção entendem que precisa ser melhorado, visão corroborada por cerca de metade dos estudantes e dos coordenadores. Esse tópico teve a mesma tendência de resposta da comunidade da escola B, cujo item foi elencado por $70 \%$ dos docentes, $67 \%$ dos coordenadores e pela direção escolar. E por quase cerca da metade dos estudantes. $\mathrm{O}$ aumento da velocidade da internet foi uma questão apontada em ambas as escolas como fundamental para o aperfeiçoamento das aulas aos estudantes.

\section{Escola B}

No tocante à infraestrutura da escola $\mathrm{B}$, tanto a direção como $40 \%$ dos estudantes e dos docentes sinalizaram a necessidade de se melhorar as condições físicas da unidade escolar. Dois professores expressaram a necessidade de cobertura da quadra esportiva e de se criar salas ambientes. Um demandou auditório, opinião destacada pela direção. Outro, ainda, requereu mais salas e equipamentos de Data show, TV e som em cada sala de aula.

Em relação ao campo "Outras sugestões" para que a qualidade do ensino seja aperfeiçoada, segundo a direção escolar é preciso "a constante melhoria da coordenação pedagógica, como ferramenta de estudo e planejamento". As sugestões dos coordenadores foram:

\footnotetext{
Criar práticas motivadoras e maior integração entre professores e professores e [entre] professores e alunos;

Trazer outros profissionais para discutir sobre profissão, adequar atividades curriculares aos estudantes com necessidades especiais;

Adquirir mais tecnologias para uma otimização do tempo de aula e maior produção intelectual. Datashow, telas interativas, laboratório de informática, etc.
}

Visão corroborada por um dos docentes, que apresentou a necessidade de "melhoria geral no ambiente tecnológico". Cumpre destacar que a escola B possui XX Datashow em condições de uso disponibilizados aos docentes; uma sala multimídia, além de um laboratório de informática com possibilidade de atender 40 estudantes.

Cabe observar que, apesar dos esforços empreendidos pelo governo federal, por meio do Programa Banda Larga nas Escolas (PBLE), criado em 2008, de acordo com os 
gestores de ambas as escolas pesquisadas, a velocidade ofertada impossibilita o atendimento de 40 alunos de uma turma, o que torna o acesso atual ineficaz. E a política pública, pouco efetiva. Para sanar esse problema, a escola B, com o apoio da APM, aumentou a velocidade da internet para 60 mega, com vistas a atender a demanda de alunos e professores.

Outro aspecto indicado pelos dirigentes e por parte dos docentes de ambas as escolas, é a carência de um auditório para a realização de eventos maiores. Na escola B, há a demanda, ainda, pela cobertura da quadra de esportes.

\subsection{Principais desafios para implementação de uma educação de melhor qualidade}

$$
\text { (Q5 - Alunos; Q2, Q3, Q6, Q8, Q9, Q10 - Docentes e Coordenação) }
$$

Os desafios para implementação de uma educação de melhor qualidade podem ser observados sob dois aspectos: o desafio de se transpor as dificuldades postas e, também, o de se ampliar os elementos que facilitam o ensino-aprendizagem. Por esse motivo, foi realizada a seguinte pergunta aos profissionais das escolas pesquisadas:

- (Q2 - docentes e coordenação): Em sua opinião, quais são os principais fatores que facilitam ou dificultam a implementação de um Ensino Médio de qualidade?

Questionados também de outras formas, buscou-se captar os desafios enfrentados pelos burocratas de linha de frente e verificar quais possam ser mitigados pelos gestores públicos tanto local, distrital e federal. As demais questões formuladas foram:

- Q3. De acordo com a sua vivência em sala de aula e com a sua experiência como coordenador/supervisor pedagógico, ou como orientador educacional, o que precisa ser feito para que se alcance essa qualidade?

- Q4. Você gosta de trabalhar nessa escola (o que te motiva)? Por quê? O que poderia melhorar?

- Q6. Com vistas à melhoria da qualidade da educação ofertada, marque abaixo as áreas que deveriam ser enfatizadas ou promovidas atividades extracurriculares na escola:

- Outros. Quais?

- Q8. Em sua opinião, o que precisa ser feito para melhorar a qualidade do Ensino Médio nessa escola? Outras sugestões:

- Q9. Em sua visão e com base em sua experiência, quais são os principais desafios para a implementação de um Ensino Médio de qualidade?

- Q10. Com vistas a aperfeiçoar a qualidade do Ensino Médio, você gostaria de deixar alguma sugestão aos gestores e aos tomadores de decisão? 
Com base nas respostas apresentadas pelos profissionais das comunidades escolares, as análises foram subdivididas nas seguintes categorias:

- Políticas Públicas;

- Planejamento e Gestão Escolar;

- Coordenação e Prática Pedagógica;

- Infraestrutura e Recursos;

- Professores;

- Alunos;

- Família.

A seguir apresentam-se, por categoria, os principais fatores que, na visão das comunidades escolares pesquisadas, influenciam na implementação de um Ensino Médio de melhor qualidade. Lembrando que a qualidade na perspectiva do próprio respondente, apresentada na resposta à Questão 1 do questionário, cujo resultado encontra-se no subitem 4.2 deste trabalho.

\subsubsection{Políticas Públicas}

\section{Escola A}

No tocante a Políticas Públicas, segundo os coordenadores da escola A os principais fatores que dificultam a melhoria educacional são: falta de políticas públicas voltadas para o Ensino Médio; falta de valorização do professor e avaliação. Um deles destacou ainda: "entrave burocrático do administrativo; morosidade. Os programas do governo às vezes se perdem antes de apresentarem resultados" (Q9 - Coordenador A).

Para os docentes da escola $\mathrm{A}$, os entraves em termos de políticas públicas são: desvalorização social e financeira dos professores; rotatividade de docentes, visão corroborada pela direção; excesso de carga horária ao docente; Lei da Mordaça/Escola sem partido; currículo engessado que não corresponde ao objetivo de vida do estudante; falta de avaliação diagnóstica de pré-requisitos do aluno para estar na série que está e excesso de alunos por turma, visão compartilhada pela direção escolar:

[...] na questão de ensino de qualidade, [...] quanto mais você reduz o número de alunos dentro de uma sala de aula, melhor a passagem do professor para o aluno o conhecimento, ele pode dar um trabalho mais individualizado para o aluno, fazer um atendimento melhor para o aluno dentro da sala de aula (Direção Escola A). 
Um dos docentes acrescentou que "estabilidade funcional, falta de cobrança na formação continuada, políticas públicas sem cobrança e sem avaliação" (Q2 - Docente A) não estimulam a melhoria do ensino.

Para um docente da escola A um dos principais desafios é:

Mudar a mentalidade da sociedade que na escola devemos formar pessoas integralmente. A escola é uma parte dessa formação. A família e as outras instituições devem fazer a sua. A escola faz tudo menos o acadêmico. Somos pais, tios, psicólogos, enfermeiros, babás, técnico de trânsitos, entre várias outras (Q9 Docente A).

No Quadro 58 expõe-se uma síntese da percepção da comunidade da escola A sobre os fatores que dificultam a melhoria da educação.

Quadro 58: Fatores que dificultam a melhoria educacional na percepção da comunidade da escola A no quesito Políticas Públicas.

Comunidade da Escola A - Fatores que dificultam a melhoria educacional
POLÍTICAS PÚBLICAS
- Desvalorização social e financeira dos professores;
- Rotatividade de professores;
- Excesso de carga horária ao docente;
- Lei da Mordaça / Escola sem partido;
- Entrave burocrático do administrativo; morosidade;
- Eão transferência dos recursos na data prevista;
- - Curráículo engessadidade funcional, falta de cobrança na formação continuada, políticas públicas sem cobrança e
- Falta de pré-requisitos/avaliação diagnóstica do aluno;
- Excesso de alunos por sala.

Entre as principais demandas e sugestões apresentadas pela comunidade escolar A para melhoria da qualidade do ensino, no tocante a políticas públicas, estão:

Uma escola atual e que seja atrativa $\mathrm{p} /$ os alunos. Despertar nos alunos o interesse pelos estudos. Estimulá-los para o futuro (Q2- Coordenador A);

Falta de foco de vida - para que serve o Ensino Médio? Se eu não for pra faculdade no que me ajuda certos conteúdos que são meramente acadêmicos? (Q9- Docente A);

Abertura para debates políticos que reflitam as principais demandas sociais do mundo contemporâneo (Q9- Docente A);

Mudanças estruturais . - Abertura por parte da direção ou da Secretaria de Educação para flexibilizar alguns projetos autorais nas escolas (Q3 - Docente A).

Avanço tecnológico. O uso de novas tecnologias em sala de aula amplia as possibilidades de aprendizagem para os alunos e novas metodologias para os professores (Q2- Coordenador A); 
Ensino integral; questão das verbas direcionadas para a escola, a escola tem que ter mais autonomia; a infraestrutura [necessita de manutenção e melhoria constantes] (Direção Escola A - E1)

Mérito como critério para o plano de carreira, descentralização e autonomia na gestão de pessoas nas escolas, sistema de avaliação institucional sério e tirar a estabilidade funcional (Q2- Docente A);

Gestores locais? São bombeiros. Gestores centrais? São surdos. Gestores Distritais e federais? São alienados. Sugiro reformular a educação. Ou melhor, o funcionalismo público (Q10- Docente A);

Atendimento psicológico para professores pelo menos duas vezes ao ano (Q9Docente A);

Elaborar um diário eletrônico - que funcione sem internet já que não dão suporte as escolas (Q10- Docente A);

Excesso de carga horária, com a mudança de 800 horas anuais para mil, os professores ficaram sobrecarregados (Q2- Docente A).

Em resumo, apresentam-se no Quadro 59 os principais aspectos relativos a políticas públicas que influenciam na melhoria da qualidade do Ensino Médio, do ponto de vista da comunidade profissional da escola A. Entre eles estão: priorizar a educação dentre do governo; valorização dos profissionais; oferecer uma escola que seja atual e atrativa para os alunos; horário em período integral; tempestividade no envio dos recursos; mais autonomia no gasto dos recursos, na gestão de pessoas e no desenvolvimento curricular.

Quadro 59: Demandas e sugestões para melhoria da educação na percepção da comunidade da escola A em relação ao quesito Políticas Públicas.

\section{Comunidade da Escola A - Demandas e sugestões para melhoria da educação}

\section{POLÍTICAS PÚBLICAS}

- Tratar educação como prioridade;

- Uma escola atual e que seja atrativa p/ os alunos;

- Políticas públicas claras e que objetivem a qualidade;

- Período integral tanto no ensino fundamental como no médio;

- Tempestividade na transferência de recursos e mais autonomia para o gasto;

- Verbas para melhoria de infraestrutura e para implementação de projetos;

- Curso aos gestores sobre Recursos Humanos;

- Leis que não penalizem o professor por índices de reprovação;

- Políticas de valorização tanto financeira quanto social dos professores;

- Cursos de aperfeiçoamento;

- Atendimento psicológico aos professores;

- Estabilidade ou permanência do professor;

- Mérito como critério para o plano de carreira, descentralização e autonomia na gestão de pessoas nas escolas sistema de avaliação institucional sério e tirar a estabilidade funcional;

- Menos alunos por sala, máximo 30 alunos;

- Investimento em logística e material. Equipar as escolas com laboratórios para possibilitar a prática;

- Liberdade curricular, mais autonomia;

- Flexibilização de projetos autorais nas escolas;

- Inovações;

- Ampliação da carga horária das matérias de ciências; 
- Transporte para os alunos participarem de eventos externos. E ingresso gratuito;

- Proporcionar estágios para os alunos do Ensino Médio obrigatório;

- Proporcionar palestrantes do MEC e do GDF para fazer palestras nas escolas.

Do ponto de vista da direção da escola A, a melhoria da educação requer escolas em período integral tanto no ensino fundamental como no médio; mais verbas e maior autonomia de uso, além de melhoria e manutenção da infraestrutura escolar.

Para os coordenadores da escola $\mathrm{A}$, os fatores que favorecem a melhoria do ensino são: a valorização do professor; menos alunos por sala; equipar as escolas com laboratórios para possibilitar a prática e o principalmente o desenvolvimento de "uma escola atual e que seja atrativa p/ os alunos" (Q2- Coordenador A). Para isso, requer-se a mudança das diretrizes curriculares, inovação, como também se faz necessário, "Avanço tecnológico. O uso de novas tecnologias em sala de aula amplia as possibilidades de aprendizagem para os alunos e novas metodologias para os professores" (Q2- Coordenador A).

Para os docentes da escola A, os principais aspectos que propulsionam o desenvolvimento de uma educação de melhor qualidade são: o governo tratar a educação como prioridade, com políticas públicas claras e que objetivem a qualidade; verbas disponibilizadas tempestivamente; melhoria da infraestrutura física e tecnológica; recursos para implementação de projetos, além de investimento em logística e material. Equipar as escolas com laboratórios para possibilitar a prática, ampliar as aulas de ciências e viabilizar transporte para os alunos participarem de eventos em teatro; cinema, além de ingresso gratuito. Capacitação de gestores na área de Gestão de Pessoas. Em relação à classe docente, indicaram: políticas de valorização tanto financeira quanto social; cursos de aperfeiçoamento; atendimento psicológico; estabilidade ou permanência em uma mesma escola; liberdade curricular e mais autonomia, com flexibilização de projetos autorais nas escolas; menos alunos por turma, além de leis que não penalizem o professor por índices de reprovação. Um docente salientou, ainda, que o mérito seja utilizado como critério para o plano de carreira, que a escola tenha autonomia na gestão de pessoas e o sistema de avaliação institucional seja sério e tire a estabilidade funcional, quando necessário. No tocante aos alunos do Ensino Médio, proporcionar estágio obrigatório e ofertar palestras com servidores do MEC e do GDF.

\section{Escola B}

No tocante a Políticas Públicas, segundo os coordenadores da escola B os principais fatores que dificultam a melhoria educacional são: não recebimento dos recursos 
tempestivamente; desvalorização do profissional de educação - professor, secretários, merendeiros, porteiros etc; não realização de novos "concursos para provimento de pessoal, principalmente na área administrativa e de apoio, terceirização da área meio na educação, pela qual não se adquire um compromisso real com a unidade educativa, pois há rotatividade"; alto número de estudantes por sala.

Para os docentes da escola $\mathrm{B}$, os dificultadores relatados em termos de políticas públicas foram: currículo extenso e não aderente à realidade do aluno, muitas vezes descontextualizado ou programado para a satisfação de avaliações externas como PAS e ENEM; desvalorização do docente e da escola, sobretudo no noturno; processo de avaliação; políticas neoliberais; congelamento salarial.

No Quadro 60, apresentam-se os principais fatores relacionados a Políticas Públicas que dificultam a melhoria educacional na percepção da comunidade da escola B.

Quadro 60: Fatores que dificultam a melhoria educacional na percepção da comunidade da escola B no quesito Políticas Públicas.

\section{Comunidade da Escola B - Fatores que dificultam a melhoria educacional}

\section{POLÍTICAS PÚBLICAS}

- Desvalorização dos docentes e da escola, sobretudo no noturno;

- Políticas Neoliberais;

- Lei da Mordaça;

- Congelamento salarial;

- Falta de apoio governamental;

- Gestores indicados pelo governo;

- Não realização de novos concursos, terceirização e rotatividade da área meio;

- Intempestividade no recebimento dos recursos;

- Alto número de estudantes por sala;

- Currículo extenso e não aderente à realidade do aluno;

- Processo de avaliação.

Ainda em termos de Políticas Públicas, para os docentes da escola B, os principais aspectos que propiciam o desenvolvimento de uma educação de melhor qualidade são: diretrizes claras; políticas públicas de incentivo; valorização da escola e do corpo docente; remuneração justa e condições de trabalho adequadas; capacitação continuada, inclusive para uso de tecnologias e para desenvolvimento de novas práticas; obrigatoriedade de salas ambientes para cada disciplina.

Para os coordenadores da escola $\mathrm{B}$, além de políticas de valorização profissional do educador, favorecem a melhoria educacional: recursos financeiros para reforma das escolas; tempestividade no envio das verbas em geral, com possibilidade de desmembramento 
para atendimento das necessidades específicas da unidade escolar; a jornada ampliada na educação, existente no DF, a qual possibilita os professores planejarem e se aperfeiçoarem no horário de coordenação pedagógica; oportunidade de licença para estudo, sem perdas salariais; a existência da escola de formação (EAPE no DF) com profissionais capacitados para ministrar cursos de formação continuada; a garantia do coordenador pedagógico na escola; redução no número de estudantes por sala (média de 40-45 por sala atualmente); concurso público para provimento de pessoal, principalmente na área administrativa e de apoio; transporte escolar público gratuito para os alunos. Assim como mudar o sistema de aulas e de avaliação, valorizando as atividades extraclasse, cultural e esportiva.

Para a direção escolar B os fatores que propulsionam a educação, em termos de políticas públicas são: professor bem remunerado e parte administrativa adequada.

Entre as principais demandas e sugestões apresentadas pela comunidade escolar B no tocante a políticas públicas estão:

Valorizar o profissional da educação, não só financeiramente, mas principalmente na participação da elaboração das políticas públicas, da elaboração das leis, por parte de seus representantes sindicais eleitos (Q3- Coordenador B);

Fazer mais discussões sobre as políticas públicas, estar mais próximos dos professores, gestores de instituições de ensino, administrativos educacionais antes da tomada de decisões, ver a escola como espaço construtor de aprendizagens e letramentos múltiplos importantes na vida social e profissional dos estudantes, portanto que merecem atenção dos governantes; Entender que, valorizar o profissional de educação é gerar qualidade à educação da população (Q9Coordenador B);

Investimento no Ensino Fundamental de qualidade, permitindo aos alunos adquirir as noções e conceitos básicos sólidos para que no Ensino Médio não apresentem deficiências e dificuldades tão comuns nas salas de aula (Q9 - Docente B);

Reformulação do Ensino Médio, com foco em áreas Humanas, Exatas, Artes... não obrigando os alunos a estudarem um número enorme de disciplinas que não são suas áreas de interesse e nem aptidões. Implementar cursos profissionalizantes a fim de preparar os alunos para o mercado de trabalho (Q10 - Docente B);

Currículo regional, propiciando a prática e o que realmente é interessante para a formação do estudante na sua integralidade (Q10 - Docente B);

Investir na capacitação dos professores, orientando e incentivando-os a conhecer a realidade dos seus alunos e trabalhar os conteúdos no exercício e práticas relacionados com a vida dele (Q3- Coordenador $\mathrm{B})$;

Investir em capacitação em valores humanos e sociais com vista a melhoria do relacionamento entre professores e alunos e conhecimento das necessidades dos alunos com o objetivo de motivar a aprendizagem (Q9- Coordenador B);

Escola de formação com profissionais capacitados para ministrar cursos de formação continuada (Q2- Coordenador B);

[...] execução [...] de concurso público para provimento de pessoal, principalmente na área administrativa e de apoio, [pois com a] terceirização da área meio na 
educação [...] não se adquire um compromisso real com a unidade educativa, pois há rotatividade (Q2- Coordenador B).

É interessante observar as demandas de um docente e de um coordenador da escola B por maior interação e aproximação entre as universidades e as escolas do Ensino Médio para o desenvolvimento de um trabalho efetivo. Tanto no sentido de parcerias como de uma formação inicial mais humana, para além da ciência, como expõem:

Que as universidades fizessem um trabalho contínuo e de parceria com os professores de Ensino Médio. Não algo que acontece hoje, onde os futuros mestres e doutores vem apenas de vez em quando, com muita pressa, totalmente dividido com outras situações e depois vão escrever livros como "entendido" do assunto (Q10 Docente B);

Proporcionar uma qualificação profissional inicial mais realista, pois se fala tanto na ciência e pouco sobre o humano; (Q9- Coordenador B).

Em resumo, apresentam-se, no Quadro 61, os principais aspectos relativos a políticas públicas que influenciam na melhoria da qualidade do Ensino Médio, do ponto de vista da comunidade profissional da escola B:

Quadro 61: Demandas e sugestões para melhoria da educação na percepção da comunidade da escola B em relação ao quesito Políticas Públicas.

\section{Comunidade da Escola B: Demandas e Sugestões para melhoria da educação}

\section{POLÍTICAS PÚBLICAS}

- Diretrizes claras;

- Investimento no Ensino Fundamental;

- Valorização da escola e do corpo docente, por meio de remuneração e condições de trabalho;

- Tempestividade no recebimento dos recursos e flexibilização do gasto;

- Recursos financeiros para reforma das escolas;

- Concurso público para provimento de pessoal, principalmente na área administrativa e de apoio;

- Valorização do ensino, buscando o novo;

- Políticas públicas de incentivo: jornada ampliada, capacitação continuada e licença para estudo;

- Mudança do Currículo do Ensino Médio, de modo a torná-lo aderente às realidades dos alunos. Currículo regional;

- Obrigatoriedade da sala ambiente;

- Redução no número de estudantes por sala (média de 40-45 por sala atualmente);

- Mudança do sistema de aulas e de avaliação, valorizando as atividades extraclasse, cultural e esportiva;

- Projetos de especialização de esportes para cada escola;

- Transporte escolar público gratuito para os alunos.

\section{Escolas A e B}

Como síntese, contrastaram-se as opiniões das duas comunidades pesquisadas, cujo resultado apresenta-se no Quadro 62. Cabe salientar que, em análise aos relatos referentes ao quesito Políticas Públicas, verificou-se direta correspondência entre os fatores 
que dificultam a implementação de uma educação de melhor qualidade, reportados pelos participantes, e as demandas e sugestões sugeridas por eles. Por esse motivo, optou-se por apresentar apenas as proposições de melhoria.

Quadro 62: Demandas e sugestões para melhoria da educação na percepção das comunidades escolares A e B em relação ao quesito Políticas Públicas.

\begin{tabular}{|c|c|c|}
\hline & ESCOLA A & ESCOLA B \\
\hline \multirow{10}{*}{ 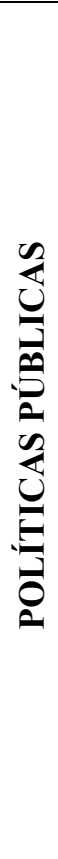 } & $\begin{array}{l}\text { Tratar educação como prioridade. Uma escola } \\
\text { atual e que seja atrativa p/ os alunos. Inovações. }\end{array}$ & Valorização do ensino, buscando o novo. \\
\hline & Melhoria do Ensino Fundamental. & Investimento no Ensino Fundamental. \\
\hline & $\begin{array}{l}\text { Políticas públicas claras e que objetivem a } \\
\text { qualidade. }\end{array}$ & Diretrizes claras. \\
\hline & $\begin{array}{l}\text { Liberdade curricular, mais autonomia. } \\
\text { Alinhamento curricular ao objetivo de vida do } \\
\text { estudante. }\end{array}$ & $\begin{array}{l}\text { Mudança do Currículo do Ensino Médio, de modo } \\
\text { a torná-lo aderente às realidades dos alunos. } \\
\text { Currículo regional. }\end{array}$ \\
\hline & $\begin{array}{l}\text { Tempestividade na transferência de recursos e } \\
\text { mais autonomia para o gasto. }\end{array}$ & $\begin{array}{l}\text { Tempestividade no recebimento dos recursos e } \\
\text { flexibilização do gasto. }\end{array}$ \\
\hline & $\begin{array}{l}\text { Políticas de valorização tanto financeira quanto } \\
\text { social dos professores. }\end{array}$ & Desvalorização dos docentes e da escola. \\
\hline & $\begin{array}{l}\text { Entrave burocrático do administrativo; } \\
\text { morosidade. }\end{array}$ & $\begin{array}{l}\text { Não realização de novos concursos, terceirização e } \\
\text { rotatividade da área meio. }\end{array}$ \\
\hline & $\begin{array}{l}\text { Políticas públicas sem cobrança e sem avaliação } \\
\text { dificultam a melhoria educacional. }\end{array}$ & Aperfeiçoar processo de avaliação. \\
\hline & Lei da Mordaça / Escola sem partido. & Lei da Mordaça. \\
\hline & Menos alunos por sala, máximo 30 alunos. & $\begin{array}{l}\text { Redução no número de estudantes por sala (média } \\
\text { de } 40-45 \text { por sala atualmente). }\end{array}$ \\
\hline
\end{tabular}

\subsubsection{Planejamento e Gestão Escolar}

\section{Escola A}

No tocante ao quesito Planejamento e Gestão Escolar, a direção da escola afirma que é preciso aumento e tempestividade no recebimento das verbas, visão corroborada por um dos coordenadores e por docentes. Porém, segundo a direção da escola A, o maior desafio, para o dirigente, refere-se à gestão de pessoas:

O maior problema da gestão são os problemas de relação entre as pessoas, é onde tem o desgaste, a falta de dinheiro é simples, não tem, dinheiro, não compra, é um problema, é, mas é um problema que eu não vou caminhando com ele, eu sei que existe esse problema, na hora que chegar a grana eu resolvo. Agora, em relação a relacionamento entre duas pessoas não, você pode até mediar, mas você sabe que as duas nunca mais vão se entender da forma que se entendiam, ou, se não se entendiam de alguma forma, com embate pior. Isso tanto serve para servidor e 
professor, aluno, aluno e aluno, aluno professor, aluno e direção, serve para todos (Direção Escola A - E1).

Para os docentes, entravam o desenvolvimento de um ensino de melhor qualidade: falta de verbas, gestão autoritária e burocrática; falta de planejamento e falta de tempo para planejar no início do ano e ambiente insalubre.

Como sugestão para a carência de recursos, um professor apontou que o gestor da unidade escolar deve: "procurar uma forma de angariar recursos para comprar papel e toner para xerox e copiadora. Providenciar internet de qualidade em todas as salas de aula; bem como equipamentos de informática. Tem que pensar atividades que tragam recursos para escola" (Q10 - Docente A).

No Quadro 63, apresentam-se os principais fatores que dificultam a melhoria educacional na percepção dos docentes.

Quadro 63: Fatores que dificultam a melhoria educacional, na percepção da comunidade da escola A, no quesito Planejamento e Gestão Escolar.

\section{Comunidade da Escola A - Fatores que dificultam a melhoria educacional}

\section{PLANEJAMENTO E GESTÃO ESCOLAR}

- Deficiência de verba e intempestividade no recebimento dos recursos;

- Problemas relativos à gestão de pessoas;

- Gestão autoritária e burocrática;

- Estrutura burocratizada de gestão;

- Falta de planejamento e falta de tempo para planejar;

- Ambiente insalubre.

Em relação aos fatores que propiciam a educação de melhor qualidade, tanto um coordenador como um professor da escola A apontaram o planejamento coletivo e participativo como um aspecto importante. Para os docentes, os principais aspectos indicados nesse quesito foram: ambiente escolar digno e agradável; equipe e gestão adequadas; suporte do corpo diretivo aos professores; profissionais capacitados; bom relacionamento com adolescentes; avaliação diagnóstica/pré-requisito dos alunos. Um aspecto destacado por um docente foi a necessidade de se "coibir o uso abusivo de celular em sala de aula" (Q9 docente A).

Segundo a direção da escola A, "Sempre tem espaço para melhorar alguma coisa, sempre tem, não tem jeito, [...] tem que estar aberto para melhorar sempre. [...] Infelizmente a gente também erra, a gente tem que errar menos, mas como é que isso acontece?” (Direção Escola A - E1). 
Em resumo, apresentam-se no Quadro 64 os principais aspectos relativos a planejamento e gestão escolar que influenciam na melhoria da qualidade do Ensino Médio, do ponto de vista da comunidade profissional da escola A.

Quadro 64: Demandas e sugestões para melhoria da educação na percepção da comunidade da escola A em relação ao quesito Planejamento e Gestão Escolar.

\section{Comunidade da Escola A - Demandas e sugestões para melhoria da educação}

\section{PLANEJAMENTO E GESTÃO ESCOLAR}

- Ambiente escolar digno e agradável;

- Boa equipe gestora;

- Gestão administrativa adequada;

- Reconhecer erros e estar aberto a melhorar;

- Suporte do corpo diretivo da escola aos professores;

- Planejamento coletivo e participativo;

- Profissionais capacitados;

- Bom relacionamento com adolescentes;

- Avaliação diagnóstica/ pré-requisito dos alunos;

- Coibir uso de celular em sala de aula.

\section{Escola B}

No quesito Planejamento e Gestão Escolar, os docentes da escola B indicaram que dificultam a melhoria educacional: gestão ineficiente e amadora tanto das escolas quanto da Secretaria de Educação; desorganização; direção autoritária e rígida em alguns pontos; falta ou falha na comunicação entre direção, escola e alunos; dificuldade em se adaptar estratégias de ensino aos alunos do noturno e fazer com que eles realmente se engajem no projeto pedagógico; a falta de conhecimento da realidade sociocultural do aluno; ausência de compromisso profissional; escola desatualizada em relação à tecnologia; ausência de atividades extraclasse, além de atividades não previstas no PPP.

Cumpre esclarecer que as perguntas que subsidiou essas respostas foram feitas de forma genérica e, não necessariamente, em relação à escola $\mathrm{B}$. Apenas duas questões foram direcionadas à escola, ambas objetivas.

Com o mesmo ponto de vista do dirigente da escola $\mathrm{A}$, a direção da escola $\mathrm{B}$ apontou como fator que dificulta a melhoria educacional a resistência de alguns docentes em aperfeiçoar sua didática e em aceitar mudanças: "professor é muito difícil, você oferece curso, você faz isso, você faz aquilo e sempre tem uma resistência, essa morosidade desse trabalho se deve à isso" (Direção Escola B, E2). Os coordenadores pedagógicos não citaram aspectos relacionados a esse quesito.

A seguir, apresenta-se no Quadro 65 o resumo das percepções no tocante aos entraves relativos a planejamento e gestão escolar para se aperfeiçoar o Ensino Médio. 
Quadro 65: Fatores que dificultam a melhoria educacional na percepção da comunidade da escola B no quesito Planejamento e Gestão Escolar.

\section{Comunidade da Escola B - Fatores que dificultam a melhoria educacional}

\section{PLANEJAMENTO E GESTÃO ESCOLAR}

- Gestão ineficiente e amadora das escolas ou das Secretarias de Educação;

- Desorganização;

- Direção autoritária e rígida em alguns pontos;

- Falta ou falha na comunicação entre direção, escola e alunos;

- Carência de capacitação do coordenador pedagógico;

- Resistência de alguns docentes em aperfeiçoar a didática, em aceitar novas propostas;

- Dificuldade em adaptar as estratégias de ensino aos alunos do noturno e fazer com que eles realmente se engajem no projeto pedagógico;

- Falta de conhecimento sobre a realidade sociocultural do aluno;

- Ausência de compromisso profissional;

- Escola desatualizada em relação à tecnologia;

- A falta de atividades extraclasse;

- Qualquer evento que exceda a proposta pedagógica da escola.

Por sua vez, como fatores da melhoria educacional, ainda em termos de planejamento e gestão escolar, os docentes da escola B apontaram: gestão democrática; equipe gestora competente; aprendizagem como foco central da escola; visão compartilhada sobre as metas da escola; boa comunicação; compromisso; ambiente prazeroso de trabalho; acessibilidade às informações de forma online.

Para os coordenadores da escola $\mathrm{B}$, os seguintes aspectos propiciam a educação de qualidade: o acesso à informação; a capacitação dos professores; o respeito às diferenças e às necessidades dos alunos, "trabalhando sempre o conteúdo programático aliado às experiências de vida e realidade dos alunos, considerar o momento político, econômico e social em que vivemos". Além do desenvolvimento de um "ambiente favorável (físico, tecnológico e administrativo) para o ensino", para o qual, conforme sinalizado pela comunidade escolar, requer-se ventiladores ou ar condicionado em cada sala, funcionando, acesso efetivo à internet; apoio administrativo.

Segundo a direção da escola B, o planejamento e a gestão escolar variam conforme o foco dado pelo gestor da unidade escolar, sua percepção e perspicácia em não perder oportunidades internas ou externas, seja motivando alunos e professores, seja construindo parcerias externas. $\mathrm{Na}$ escola $\mathrm{B}$, a direção enfatizou que trabalha muito a questão da disciplina com os alunos, "a rigidez é: [uso de] uniforme, chegar no horário, respeito ao professor, respeito ao colega e [combate ao] bullying", esse último, mais comum no ensino fundamental, segundo a direção. Outra questão apontada foi a não permissão de namoro dentro da escola. Conforme aponta a dirigente: 
o foco, ele se sentir responsável e o acolhimento [...] é muito aconselhamento, muita conversa, muita firmeza na disciplina [...] Tem que ser feliz aqui, você pertence, a escola é sua, nós estamos fazendo isso para vocês, porque são vocês que vão aproveitar, a família de vocês, [...] tudo isso que estamos fazendo aqui é para o futuro de vocês, e o futuro é rápido, então vamos acordar (Direção Escola B - E2).

Dessa forma, na percepção da direção, entre os fatores que influenciam e propiciam a qualidade da educação ofertada estão: objetivo, motivação e atuação do gestor; gestão compartilhada, parcerias externas, muito diálogo e cobrança de disciplina do estudante.

Os principais aspectos apresentados pela comunidade escolar B, no tocante ao quesito planejamento e gestão, que influenciam na implementação de uma educação de melhor qualidade foram:

Equipe gestora competente, corajosa e que não teme os desafios demandados diariamente por uma comunidade complexa (Q2 - Docente B);

Olhar da direção presente para resolver e minimizar possíveis problemas professores e alunos terão (Q2 - Docente B).

Integração de todos os setores da comunidade escolar na busca conjunta de ações que possam ter efeitos significativos no processo da busca da qualidade profissional (Q3 - Docente B);

Capacitação dos professores em lidar com diferenças de opinião entre eles, conservando o respeito diante das adversidades e conservando o objetivo maior de promover educação de qualidade (Q9 - Coordenador B);

Entender melhor a política pública denominada Semestralidade, pois tem itens interessantes que auxiliaria na aprendizagem desta etapa (Q9 - Coordenador B);

Ambiente favorável (físico, tecnológico e administrativo) para o ensino (Q3 Coordenador B).

Cumpre salientar que, em relação às instâncias superiores, a direção da escola B sente-se amparada pela Secretaria de Educação do GDF. Disse promoverem muitas ações: feiras, encontros, fóruns, reuniões mensais com os dirigentes e quinzenais com os coordenadores pedagógicos, além de capacitações aos docentes por meio da EAPE. Oferecem, também, aulas preparatórias para a prova do ENEM para uma parcela dos alunos.

Sobre o compartilhamento de boas práticas, ambas as direções escolares disseram que o celular tem sido utilizado como ferramenta de gestão. A Secretaria de Educação criou grupos no WhatsApp por meio dos quais ela pede fotos, informações, e acompanha as escolas:

a direção da regional tem tentado isso [celular], sabe, todas as vezes compartilha foto, compartilha isso [por WhatsApp], o que as outras escolas estão inovando, o que elas estão achando de alternativas, o que estão fazendo para a coordenação ser melhor, o que estão fazendo para o aluno ter mais interessa nas aulas. O que vocês estão fazendo? Vamos compartilhar [dizem]. A coordenação nova ela tem feito o que, toda reunião ela tem colocado slides do que as escolas têm feito. Tem sido excelente isso, porque as pessoas se sentem bem de ir na reunião e ver a escola dela 
lá, com isso [celular] então eu acho que pode começar a ter essa cultura do partilhar mais (Direção Escola B, E2).

A direção da escola B informou, ainda, que a Regional de Ensino também envia um coordenador intermediário que acompanha regularmente se a escola está realizando o que foi planejado nas reuniões com os coordenadores pedagógicos, e se não está, por que não. Informou que o próprio coordenador intermediário relata muita dificuldade em gerir os coordenadores.

Em resumo, apresentam-se, no Quadro 66, os principais aspectos relativos a planejamento e gestão escolar que influenciam na melhoria da qualidade do Ensino Médio, do ponto de vista da comunidade profissional da escola B.

Quadro 66: Demandas e sugestões para melhoria da educação na percepção da comunidade da escola B em relação ao quesito Planejamento e Gestão Escolar.

\section{Comunidade da Escola B: Demandas e Sugestões para melhoria da educação}

\section{PLANEJAMENTO E GESTÃo ESCOLAR}

- Ambiente prazeroso de trabalho;

- Gestão democrática;

- Equipe gestora competente;

- Planejamento conjunto de todas as áreas da escola;

- Aprendizagem como foco central da escola;

- Trabalho em equipe e compromisso com a educação;

- Visão compartilhada sobre as metas da escola;

- Boa comunicação;

- Uso do aplicativo de celular WhatsApp como ferramenta de gestão e divulgação de boas práticas;

- Capacitação dos professores;

- Construção de parcerias externas;

- Acesso à informação e de forma online;

- Respeito às diferenças;

- Respeito às necessidades dos alunos, diálogo e cobrança de disciplina;

- Combate à violência e ao tráfico de drogas.

Entre as sugestões deixadas aos gestores e tomadores de decisão estão itens relacionados à gestão de pessoas:

Sejam imparciais e extremamente profissionais; - busquem objetividade, burocracia desestimula qualquer profissional; - Se um profissional errar, chame-o em sua sala e dialogue para resolver a situação, pois chamar a atenção de uma equipe inteira por causa do erro de um ou outro desestimula o trabalho de quem tentou trabalhar corretamente a vida inteira; - Foquem na produção e qualidade de ensino, picuinhas internas não devem ser alimentadas; - o gestor da escola pública deve necessariamente ter vivenciado a regência da classe (Q10 - Docente B).

Cabe observar que tanto o dirigente da escola A como o da escola B, vivenciaram a regência de turma por 15 anos e 26 anos, respectivamente. 


\section{Escolas A e B}

Como síntese em relação ao tema planejamento e gestão escolar, contrastaram-se as opiniões das duas comunidades pesquisadas, cujos resultados apresentam-se nos Quadros 67 e 68 , os quais indicam, respectivamente, os fatores que dificultam a implementação de uma educação de melhor qualidade, reportados pelos participantes, assim como as demandas e as sugestões expostas.

Quadro 67: Fatores que dificultam a melhoria educacional na percepção das comunidades escolares A e B em relação ao quesito Planejamento e Gestão Escolar.

\begin{tabular}{|c|c|c|}
\hline & ESCOLA A & ESCOLA B \\
\hline \multirow{4}{*}{ 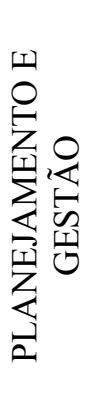 } & $\begin{array}{l}\text { Deficiência de recursos. Intempestividade na } \\
\text { transferência de recursos e mais autonomia para o } \\
\text { gasto. }\end{array}$ & $\begin{array}{l}\text { Aumento de verba. Tempestividade no } \\
\text { recebimento dos recursos e flexibilização do } \\
\text { gasto. }\end{array}$ \\
\hline & Problemas relativos à gestão de pessoas. & $\begin{array}{l}\text { Falta ou falha na comunicação entre direção, } \\
\text { escola e alunos. }\end{array}$ \\
\hline & Gestão autoritária e burocrática. & Direção autoritária e rígida em alguns pontos. \\
\hline & $\begin{array}{l}\text { Dificuldade de alguns docentes em aceitar } \\
\text { mudanças. }\end{array}$ & $\begin{array}{l}\text { Resistência de alguns docentes em aperfeiçoar a } \\
\text { didática, em aceitar novas propostas. }\end{array}$ \\
\hline
\end{tabular}

Quadro 68: Demandas e sugestões para melhoria da educação na percepção das comunidades escolares A e B em relação ao quesito Planejamento e Gestão Escolar

\begin{tabular}{|c|c|c|}
\hline & ESCOLA A & ESCOLA B \\
\hline \multirow{5}{*}{ 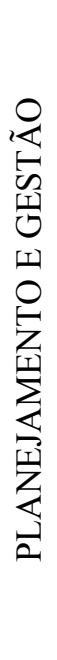 } & Ambiente escolar digno e agradável. & Ambiente prazeroso de trabalho. \\
\hline & Boa equipe gestora. & $\begin{array}{l}\text { Gestão democrática e equipe gestora } \\
\text { competente; boa comunicação e respeito às } \\
\text { diferenças. }\end{array}$ \\
\hline & $\begin{array}{l}\text { Planejamento coletivo e participativo. } \\
\text { Alinhamento de interesses entre direção escolar, } \\
\text { coordenação pedagógica e docentes. }\end{array}$ & $\begin{array}{l}\text { Planejamento conjunto de todas as áreas da } \\
\text { escola. Visão compartilhada sobre as metas da } \\
\text { escola. Trabalho em equipe e compromisso com } \\
\text { a educação. }\end{array}$ \\
\hline & $\begin{array}{l}\text { Profissionais capacitados: docentes; gestores em } \\
\text { Recursos Humanos. }\end{array}$ & $\begin{array}{l}\text { Capacitação: dos professores; da coordenação } \\
\text { pedagógica tanto em novos métodos e recursos } \\
\text { pedagógicos, como em gestão. }\end{array}$ \\
\hline & $\begin{array}{l}\text { Avaliação diagnóstica/ pré-requisito dos alunos. } \\
\text { Bom relacionamento com adolescentes. }\end{array}$ & $\begin{array}{l}\text { Falta de conhecimento sobre a realidade } \\
\text { sociocultural do aluno; Respeito às necessidades } \\
\text { dos alunos e diálogo. }\end{array}$ \\
\hline
\end{tabular}




\subsubsection{Coordenação e Prática Pedagógica}

\section{Escola A}

Em relação ao quesito Coordenação e Prática Pedagógica, coordenadores e docentes da escola A citaram como fatores que dificultam o desenvolvimento de um ensino de melhor qualidade: a falta de coordenador de área para orientar efetivamente o trabalho pedagógico no que concerne a planejamento didático e de atividades de área; manutenção dos mesmos projetos durante anos - falta de criatividade; ausência de pré-requisitos para o aluno estar na série e falta de apoio administrativo.

Para alguns docentes e para a direção escolar, o déficit de conhecimento trazido do ensino fundamental e o excesso de alunos por turma prejudicam também a melhoria da aprendizagem. A direção destacou, ainda, o papel e a importância de se alinhar interesses com o coordenador pedagógico, pois como foram escolhidos pelos docentes, "se eu tiver um processo de embate direto com a coordenação eu vou sair bem prejudicado" (Direção Escola A - E1). O Quadro 69 apresenta o resumo dos principais fatores expostos.

Quadro 69: Fatores que dificultam a melhoria educacional na percepção da comunidade da escola A no quesito Coordenação e Prática Pedagógica.

\section{Comunidade da Escola A - Fatores que dificultam a melhoria educacional}

\section{COORDENAÇ̃̃o E PRÁTICA PEDAGÓGICA}

- Falta de coordenador de área para orientar efetivamente o trabalho pedagógico;

- Defasagem de conhecimento prévio do aluno e ausência de avaliação diagnóstica de pré-requisitos para o aluno estar na série;

- Excesso de alunos por turma;

- Os mesmos projetos durante anos. Falta de criatividade;

- Falta de apoio administrativo.

Um aspecto apontado pela coordenação como favorável à melhoria educacional é o horário de coordenação, momento em que todos os docentes podem estudar e planejar em conjunto, assim como contribuir com ideias e sugestões para o melhor desenvolvimento do trabalho. Entre as principais demandas e sugestões apresentadas pela comunidade escolar A no tocante a coordenação e à prática pedagógica estão apresentadas no Quadro 70. 
Quadro 70: Demandas e sugestões para melhoria da educação na percepção da comunidade da escola A em relação ao quesito Coordenação e Prática Pedagógica.

\section{Comunidade da Escola A - Demandas e sugestões para melhoria educacional}

\section{COORDENAÇÃo E PRÁtICA PEDAGóGICA}

- Alinhamento de interesses entre direção escolar, coordenação pedagógica e docentes;

- Prática pedagógica e avaliações coerentes com a prática;

- Planejamento pedagógico como princípio norteador das práticas interdisciplinares;

- Organização com o desenvolvimento do conteúdo anual em consonância com a L.D.B., P. A.S./UnB, vestibular, ENEM;

- Foco no processo de ensino aprendizagem / o que é ensinado em relação ao que é avaliado; Compreensão da finalidade avaliativa;

- Projetos de escola que formam cidadãos, elaborados em conjunto pelos professores;

- Pesquisa e trabalho científico;

- Apoio pedagógico;

- Oficinas com temas transversais;

- Suporte consistente da coordenação;

- Colaboração de todos os agentes envolvidos;

- Inovações;

- Manter o ambiente digno e combater a insalubridade.

\section{Escola B}

Corroborando a visão da direção da escola A, segundo a direção da escola B, para que a melhoria educacional se realize é preciso focar na "constante melhoria da coordenação pedagógica". Para ela, o coordenador pedagógico “é o esteio, vai ver como está o planejamento do professor, ajudar na diversidade de atividades” (Direção Escola B, E2).

De acordo com a direção, na escola B, "o clima [entre os profissionais] é tranquilo, mas é morno. A direção gostaria de avançar em termos de qualidade, mas os docentes escolhem um coordenador pedagógico que mantenha, de certo modo, o status quo. Que não requeira muitas mudanças" (Direção Escola B, E2). Como a direção da escola A, a da escola B enfatizou a importância do coordenador pedagógico:

A coordenação pedagógica, eu acredito que para você ser coordenador você tinha que ter mais que um perfil, você tinha que ter um estudo de gestão, você entendeu? Eu para ser gestora, nós [direção e vice] tivemos que fazer um curso de gestão. [...] E a coordenação é o coração da escola, a coordenação é que vai ver se o professor cumpre o planejamento, se o professor está seguindo o currículo, se o professor está com alguma dificuldade, qual a dificuldade que ele está, que ferramentas que eu vou ajudá-lo, qual a ferramenta que eu vou ajudar para que ele supere aquela dificuldade que ele está em sala de aula (Direção Escola B, E2).

Questionada sobre questões de uso de jogos, softwares educativos, a direção relatou que a escola até possui, "mas não é utilizado, [...] então por isso que o confronto vem lá da coordenação, você entendeu, porque eu acredito que a coordenação é ainda mais importante do que a escolha do professor, porque se eu tivesse uma boa coordenação esse uso 
poderia ser estimulado" (Direção Escola B, E2). Para ela, o coordenador precisa ser proativo, buscar extrapolar, melhorar, pesquisar.

Além disso, tanto para a direção escolar como para a coordenação pedagógica da escola B, são aspectos que dificultam a coordenação e a prática pedagógica: o não pagamento das verbas integralizadas para as escolas tempestivamente; o número alto de estudantes por sala e a resistência por parte de alguns professores em aperfeiçoar a didática em sala de aula, assim como: "A pouca capacitação de alguns professores ou falta de vontade em dedicar os seus conhecimentos e vivências em suas salas de aula, com vistas a motivar o aluno; $\mathrm{O}$ preconceito remanescente e a falta de sensibilidade dos docentes em relação à realidade dos alunos" (Q2 - Coordenação B).

Segundo os docentes, os fatores que dificultam a boa prática pedagógica são: o currículo do Ensino Médio não ser aderente às realidades dos alunos; grade curricular extensa, muitas vezes descontextualizada ou programada para a satisfação de avaliações externas como PAS, ENEM entre outras; processo de avaliação existente, que não corresponde à realidade; falta de conhecimento sobre a realidade sociocultural do aluno; dificuldade em adaptar as estratégias de ensino aos alunos do noturno e fazer com que eles realmente se engajem no projeto pedagógico; uso excessivo de celular por parte do aluno; falta de compromisso profissional; escola desatualizada em relação à tecnologia; ausência de atividades extraclasse; assim como qualquer evento que esteja fora da proposta pedagógica da escola.

A seguir, apresenta-se no Quadro 71 o resumo das percepções da comunidade escolar no tocante aos entraves relativos a coordenação e prática pedagógica para se aperfeiçoar o Ensino Médio.

Quadro 71: Fatores que dificultam a melhoria educacional na percepção da comunidade da escola B no quesito Coordenação e Prática Pedagógica.

\section{Comunidade da Escola B - Fatores que dificultam a melhoria educacional}

\section{COORDENAÇÃo E PRÁTICA PEDAGóGICA}

- Intempestividade no envio dos recursos financeiros;

- Currículo não aderente às realidades dos alunos;

- Grade curricular extensa, muitas vezes descontextualizada ou programada para a satisfação de avaliações externas como PAS, ENEM entre outras;

- Processo de avaliação;

- Falta de conhecimento da realidade sociocultural do aluno;

- Falta de compromisso profissional;

- Preconceito e falta de sensibilidade de alguns docentes em relação aos alunos e suas necessidades;

- Resistência de docentes em aperfeiçoar sua didática;

- Coordenação pedagógica passiva ou não proativa;

- Quantidade de aluno por turma;

- Uso de celular em sala;

- Dificuldade em adaptar as estratégias de ensino aos alunos do noturno; 
- Escola desatualizada em relação à tecnologia;

- A falta de atividades extraclasse;

- Qualquer evento que esteja fora da proposta pedagógica da escola.

Para a direção escolar, facilita a coordenação quando o aluno já estuda na escola desde o oitavo ano do ensino fundamental e quando não há muita rotatividade de estudantes. Um aspecto apontado pela coordenação como favorável à melhoria educacional é:

Aqui em Brasília, fatores facilitadores foram, por exemplo, a jornada ampliada na educação, que favorece aos professores momentos de estudo e qualificação no turno contrário ao de regência, sem perdas salariais, Licença para estudos - que o atual governo pensa não dar mais por um bom tempo - , uso de ônibus público para buscar/levar os alunos de casa para a escola e vice versa, a garantia do coordenador na escola, a existência de uma escola de formação com profissionais capacitados para ministrar cursos de formação continuada (Q2 - Coordenação B).

No tocante a prática pedagógica, foram apontados pelos docentes da escola $\mathrm{B}$ como determinantes de um ensino de melhor qualidade: reuniões de coordenação; organização do espaço escolar - ambiente físico, tempo das aulas, calendário unificado de atividades dentro da unidade educacional; otimização do tempo escolar; o uso de novos métodos: audiovisuais e computação, alertando para a necessidade de preparação (capacitação) dos profissionais da escola nesse sentido; trabalho árduo focado no ENEM com simulados e provas bimestrais em conjunto. Oficinas de leitura e redação para estimular a criatividade do aluno e disponibilização de plantão de dúvidas. Assim como "amplo leque de oportunidade para o conhecimento", que pode ser compreendido como a oferta estruturada de formas diferentes de acesso ao conhecimento, por exemplo: oficinas práticas; uso de jogos e softwares educativos, vídeos e internet, inclusive por meio de celular.

Em relação ao item coordenação e prática pedagógica, as principais demandas e sugestões apresentadas pela comunidade escolar B foram:

Criar um modo de ensinar que, verdadeiramente, o aluno tenha prazer em estudar (Q9 - Docente B);

Instrumentalizar os alunos como agentes de mudanças ao invés de "treiná-los" para as avaliações que terão que enfrentar. Neste sentido, o projeto político pedagógico da escola deve ser voltado para a educação para a vida, um projeto inovador para o Ensino Médio que vise a formação de agentes transformadores e fuja do modelo "tradicional" de Ensino Médio (Q9 - Docente B);

Respeito às necessidades dos alunos, trabalhando sempre o conteúdo programático aliado às experiências de vida e realidade dos alunos, considerar o momento político, econômico e social em que vivemos (Q2 - Coordenador B);

Aproveitar a disciplina PI [Projeto Interdisciplinar] para aplicar um projeto específico trabalhado com todos os professores (Q3 - Docente B); 
Fazer com que a escola seja vista pelos alunos como deles - onde possam discutir a melhor forma da implementação curricular (Q9 - Docente B);

Trabalhar com reforço de conteúdos, pois frequentemente encontramos alunos com déficit de conhecimento anterior (Q9 - Coordenador B).

Trabalhar com a tecnologia em sala de aula, trazendo o celular para aula como recurso promotor de aprendizagem (Q9 - Coordenador B).

O Quadro 72 apresenta um resumo das demandas e sugestões apresentadas pela comunidade escolar B com vistas à melhoria da educação.

Quadro 72: Demandas e sugestões para melhoria da educação na percepção da comunidade da escola B em relação ao quesito Coordenação e Prática Pedagógica.

\section{Comunidade da Escola B: Demandas e sugestões para melhoria da educação}

\section{COORDENAÇÃo E PRÁTICA PEDAGÓGICA}

- Capacitação do coordenador pedagógico;

- Projetos pedagógicos para os três anos;

- Conhecer melhor o aluno, suas realidades e aspirações. Respeito às suas necessidades;

- Reuniões de coordenação, estudar os fatores que dificultam o ensino aprendizado;

- Discutir coletivamente o projeto interdisciplinar;

- Organização do espaço e otimização do tempo escolar;

- Repensar novos métodos de ensino: uso de audiovisuais e computação, bem como a preparação (capacitação) dos profissionais da escola nesse sentido. Tornar as aulas motivadoras e mais atraentes tanto para o aluno quanto para o professor;

- Oficinas de leitura e redação;

- Celular: uso como recurso promotor de aprendizagem e restrição ao uso abusivo;

- Propiciar meios do aluno se sentir pertencente e protagonista na escola;

- Estimular a busca pelo saber;

- Ativar os laboratórios de biologia, física e química;

- Projetos de inclusão digital;

- Plantão de dúvidas e reforço escolar, inclusive com vistas a mitigar déficit de conhecimento prévio do ensino fundamental;

- Ambientes de estudo no contra turno às aulas;

- Trazer profissionais externos para debater temas, profissões.

\section{Escolas A e B}

Como síntese no tocante ao tema Coordenação e Prática Pedagógica, contrastaram-se as opiniões das duas comunidades pesquisadas. Os resultados apresentam-se nos Quadros 73 e 74, os quais indicam, respectivamente, os fatores que dificultam a implementação de uma educação de melhor qualidade, reportados pelos participantes, assim como as demandas e as sugestões expostas. 
Quadro 73: Fatores que dificultam a melhoria educacional na percepção das comunidades escolares A e B em relação ao quesito Coordenação e Prática Pedagógica.

\begin{tabular}{|l|l|l|}
\hline & \multicolumn{1}{|c|}{ ESCOLA A } & \multicolumn{1}{|c|}{ ESCOLA B } \\
\hline \multirow{2}{*}{} & $\begin{array}{l}\text { Intempestividade no envio dos recursos } \\
\text { financeiros. }\end{array}$ & $\begin{array}{l}\text { Intempestividade no envio dos recursos } \\
\text { financeiros. }\end{array}$ \\
\cline { 2 - 3 } & $\begin{array}{l}\text { Currículo engessado. Falta de alinhamento } \\
\text { curricular ao objetivo de vida do estudante. }\end{array}$ & $\begin{array}{l}\text { Currículo não aderente às realidades dos alunos. } \\
\text { Grade curricular extensa, muitas vezes } \\
\text { descontextualizada ou programada para a } \\
\text { satisfação de avaliações externas como PAS, } \\
\text { ENEM entre outras. }\end{array}$ \\
\cline { 2 - 3 } & $\begin{array}{l}\text { Os mesmos projetos durante anos. Falta de } \\
\text { criatividade. Falta de coordenador de área para } \\
\text { orientar efetivamente o trabalho pedagógico. }\end{array}$ & $\begin{array}{l}\text { Coordenação pedagógica passiva ou não } \\
\text { proativa. }\end{array}$ \\
\cline { 2 - 3 } & $\begin{array}{l}\text { Defasagem de conhecimento prévio do aluno e } \\
\text { ausência de avaliação diagnóstica de pré- } \\
\text { requisitos para o aluno estar na série. }\end{array}$ & $\begin{array}{l}\text { A base do aluno advinda do ensino fundamental. } \\
\text { Falta de conhecimento da realidade } \\
\text { sociocultural do aluno. }\end{array}$ \\
\cline { 2 - 3 } & $\begin{array}{l}\text { Excesso de alunos por turma. } \\
\text { Alto número de estudantes por sala. }\end{array}$ \\
\hline
\end{tabular}

Quadro 74: Demandas e sugestões para melhoria da educação na percepção das comunidades escolares A e B em relação ao quesito Coordenação e Prática Pedagógica.

\begin{tabular}{|c|c|c|}
\hline & ESCOLA A & ESCOLA B \\
\hline \multirow{4}{*}{ 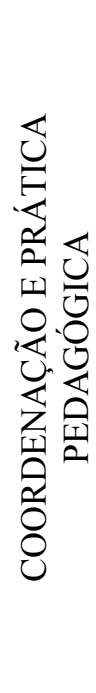 } & $\begin{array}{l}\text { Alinhamento de interesses entre direção escolar, } \\
\text { coordenação pedagógica e docentes. }\end{array}$ & $\begin{array}{l}\text { Planejamento conjunto de todas as áreas da } \\
\text { escola. Visão compartilhada das metas. }\end{array}$ \\
\hline & $\begin{array}{l}\text { Apoio pedagógico; suporte consistente da } \\
\text { coordenação; prática pedagógica e avaliações } \\
\text { coerentes com a prática. Foco no processo de } \\
\text { ensino aprendizagem / o que é ensinado em } \\
\text { relação ao que é avaliado; Compreensão da } \\
\text { finalidade avaliativa. Projetos de escola que } \\
\text { formam cidadãos, elaborados em conjunto. } \\
\text { Oficinas com temas transversais; Colaboração } \\
\text { de todos os agentes envolvidos; Inovações. }\end{array}$ & $\begin{array}{l}\text { Capacitação do coordenador pedagógico. } \\
\text { Projetos pedagógicos para os três anos. } \\
\text { Estudar, nas reuniões de coordenação, os fatores } \\
\text { que dificultam o ensino aprendizado. Processo } \\
\text { de avaliação. Repensar novos métodos de } \\
\text { ensino: uso de audiovisuais e computação, bem } \\
\text { como a preparação (capacitação) dos } \\
\text { profissionais da escola nesse sentido. Tornar as } \\
\text { aulas motivadoras e mais atraentes tanto para o } \\
\text { aluno quanto para o professor. }\end{array}$ \\
\hline & & $\begin{array}{l}\text { Conhecer melhor o aluno, suas realidades e } \\
\text { aspirações. Respeito às suas necessidades. } \\
\text { Estimular a busca pelo saber. }\end{array}$ \\
\hline & Uso de celular em sala, incômodo. & $\begin{array}{l}\text { Celular: uso como recurso promotor de } \\
\text { aprendizagem e restrição ao uso abusivo. }\end{array}$ \\
\hline
\end{tabular}




\subsubsection{Infraestrutura e Recursos}

\section{Escola A}

No tocante à infraestrutura e recursos, um coordenador da escola A apontou que a falta de internet e de material de trabalho para o professor restringem a melhoria do ensino. Entre os docentes, foram indicados os seguintes aspectos: salas de aula muito quentes, ventiladores quebrados; falta de recursos materiais didáticos; falta de tecnologias; assim como carência de recursos físicos e humanos (mais professores para que se pudesse trabalhar de forma mais eficiente aulas práticas em laboratório). No Quadro 75, apresentam-se os principais fatores que dificultam a melhoria educacional na percepção da comunidade escolar.

Quadro 75: Fatores que dificultam a melhoria educacional na percepção da comunidade da escola A no quesito Infraestrutura e Recursos.

\section{Comunidade da Escola A - Fatores que dificultam a melhoria educacional}

\section{INFRAESTRUTURA E RECURSOS}

- Salas muito quentes;

- Falta de recursos materiais didáticos;

- Falta de internet e de tecnologias;

- Falta recursos físicos e humanos (mais professores para que se pudesse trabalhar de forma mais eficiente aulas práticas (em laboratório).

Entre os principais recursos apontados pela comunidade da escola A que propiciam uma educação de melhor qualidade estão:

Ter ferramentas para poder ministrar aulas com melhor aproveitamento, tais como internet funcionando, projetor, quadro com tela interativa; ventiladores ou ar condicionados nas salas, de preferência funcionando (Q10 - Docente A);

Avanço tecnológico. O uso de novas tecnologias em sala de aula amplia as possibilidades de aprendizagem para os alunos e novas metodologias para os professores (Q2 - Coordenador A).

Do ponto de vista da direção da escola A, faz-se necessário aumento de verbas e melhoria e manutenção da infraestrutura escolar existente, tanto tecnológica, aumento da velocidade da internet; como física, encanamentos e rede elétrica.

O Quadro 76 apresenta um resumo das demandas e sugestões, no tocante a infraestrutura e recursos, apresentadas pela comunidade escolar A com vistas à melhoria da educação. Entre elas estão: aumento no número coordenadores, supervisores pedagógicos e contratação de docentes específicos para as aulas em laboratório; mais espaços físicos e 
equipamentos; materiais didáticos adequados e inovadores que atraiam os estudantes; ventilador ou ar condicionado, assim como internet de alta velocidade, em cada sala de aula.

Quadro 76: Demandas e sugestões para melhoria da educação na percepção da comunidade da escola A em relação ao quesito Infraestrutura e Recursos.

\section{Comunidade da Escola A - Demandas e sugestões para melhoria da educação}

\section{INFRAESTRUTURA E RECURSOS}

- Aumento de verbas;

- Aumento no número de profissionais (coordenadores, supervisores pedagógicos e docentes para os laboratórios);

- Mais espaços físicos e equipamentos;

- Materiais didáticos adequados e inovadores;

- Investir em materiais para se viabilizar aulas, projetos e oficinas;

- Investir em computadores e internet de alta velocidade para sala de aula;

- Informática, biblioteca e laboratório;

- Melhoria e manutenção da infraestrutura escolar;

- Ventilador ou ar condicionado em cada sala.

\section{Escola B}

Em relação ao quesito infraestrutura e recursos pedagógicos, docentes e coordenadores da escola B apontaram que problemas estruturais dificultam a melhoria do ensino, tais como: deficiência de salas adequadas, de materiais e de recursos para incremento de tecnologia, conforme se verifica no Quadro 77.

Quadro 77: Fatores que dificultam a melhoria educacional na percepção da comunidade da escola B no quesito Infraestrutura e Recursos.

\section{Comunidade da Escola B - Fatores que dificultam a melhoria educacional}

\section{INFRAESTRUTURA E RECURSOS}

- Estrutura precária;

- Falta de salas adequadas;

- Deficiência de materiais e de pessoal;

- Falta de incremento em tecnologia.

Em relação a esse tema, um docente indicou como positivo o fato da escola ser pequena, o que "facilita um trabalho com maior profundidade" (Q4 - Docentes B). Para os demais professores, ensejam ensino de qualidade: estrutura escolar propícia, boas instalações e o reaparelhamento das escolas com vistas à inclusão digital e no tocante aos laboratórios 
para as diversas disciplinas. Além de recursos para se viabilizar: oficinas práticas; jogos e softwares educativos, vídeos e internet.

Nesse sentido, os principais pontos destacados pela comunidade escolar foram:

Encontrar meios para estimular os alunos a estudar (Q3 - Docentes B);

Investir em aquisição de tecnologias para utilização em aulas e capacitação para sua utilização (Q3 - Coordenador B);

Ativar os laboratórios de biologia, física e química (Q9 - Docente B);

Precisaríamos de ter recursos tecnológicos e audiovisuais em cada sala de aula. Atualmente, contamos com datas shows móveis e uma sala de multimídia. Entretanto, perdemos, geralmente, 10 minutos da aula montando os aparelhos (Q3 Docentes B).

No Quadro 78, apresentam-se os principais aspectos relativos à infraestrutura e recursos que influenciam na melhoria da qualidade do Ensino Médio, do ponto de vista da comunidade profissional da escola B.

Quadro 78: Demandas e sugestões para melhoria da educação na percepção da comunidade da escola B em relação ao quesito Infraestrutura e Recursos.

\section{Comunidade da Escola B: Demandas e sugestões para melhoria da educação}

\section{INFRAESTRUTURA E RECURSOS}

- Escola menor propicia melhores condições de ensino aprendizagem;

- Melhoraria a infraestrutura: implementar salas ambientes; construir auditório e cobrir a quadra esportiva;

- Reaparelhamento das escolas - inclusão digital e laboratórios para as diversas disciplinas;

- Aprimoramento geral do ambiente tecnológico: acesso à internet, Datashow, TV e som em cada sala;

- Disponibilizar jogos e softwares educativos, vídeos e internet de alta velocidade;

- Ativar os laboratórios de biologia, física e química e realizar manutenção de carteiras, quadro-negro, janelas e banheiros.

Cabe informar que os coordenadores da escola B não apontaram aspectos facilitadores em relação aos temas: infraestrutura e recursos pedagógicos; professores, alunos ou família.

\section{Escolas A e B}

Em síntese, contrastaram-se as opiniões das duas comunidades pesquisadas em relação ao quesito Infraestrutura e Recursos. Como se verificou correspondência direta entre os fatores que dificultam a implementação de uma educação de melhor qualidade e as 
demandas e sugestões propostas pelos participantes da pesquisa, optou-se por apresentar apenas as proposições de melhoria, conforme Quadro 79.

Quadro 79: Demandas e sugestões para melhoria da educação na percepção das comunidades escolares A e B em relação ao quesito Infraestrutura e Recursos.

\begin{tabular}{|c|c|c|}
\hline & ESCOLA A & ESCOLA B \\
\hline \multirow{4}{*}{ 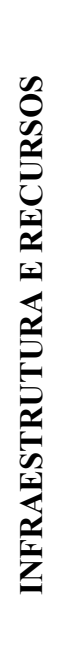 } & $\begin{array}{l}\text { Melhoria e manutenção da infraestrutura escolar. } \\
\text { Mais espaços físicos e equipamentos. Salas muito } \\
\text { quentes, ventilador ou ar condicionado em cada } \\
\text { sala. }\end{array}$ & $\begin{array}{l}\text { Melhoria da infraestrutura: implementar salas } \\
\text { ambientes; construir auditório e cobrir a quadra } \\
\text { esportiva e laboratórios para as diversas } \\
\text { disciplinas. Estrutura precária. Falta de salas } \\
\text { adequadas. }\end{array}$ \\
\hline & $\begin{array}{l}\text { Aumento no número de profissionais } \\
\text { (coordenadores, supervisores pedagógicos e } \\
\text { docentes para os laboratórios). }\end{array}$ & Deficiência de pessoal. \\
\hline & $\begin{array}{l}\text { Materiais didáticos adequados e inovadores; } \\
\text { investir em materiais para se viabilizar aulas, } \\
\text { projetos e oficinas. }\end{array}$ & $\begin{array}{l}\text { Deficiência de materiais. Falta de incremento em } \\
\text { tecnologia. }\end{array}$ \\
\hline & $\begin{array}{l}\text { Investir em computadores e internet de alta } \\
\text { velocidade para sala de aula; Informática, } \\
\text { biblioteca e laboratório. }\end{array}$ & $\begin{array}{l}\text { Aprimoramento geral do ambiente tecnológico: } \\
\text { acesso à internet, Datashow, TV e som em cada } \\
\text { sala; } \\
\text { Disponibilizar jogos e softwares educativos, } \\
\text { vídeos e internet de alta velocidade. }\end{array}$ \\
\hline
\end{tabular}

\subsubsection{Professores e condições de trabalho}

\section{Escola A}

Em relação à classe docente e às condições de trabalho, os principais fatores relatados pelos professores da escola A que dificultam a melhoria do Ensino Médio são: excesso de alunos por sala, apontado por três docentes; formação deteriorada dos professores e doenças relativas ao exercício, como exposto: "Doenças relativas à profissão docente como calo nas cordas vocais, estresse, acúmulo de trabalho como provas, exercícios, projetos, gincanas, feiras, seminários; excesso de alunos etc" (Q2 - Docente A). Além da desvalorização social e financeira da profisssão, também apontada por um dos coordenadores. Para a direção escolar:

\footnotetext{
as pessoas têm dificuldades tremendas, tem professor com métodos antigos, que não abre mão, de repente, de um aluno sentar mais descontraído, "senta direito!" Então tem aluno que vem aqui e fala, mas o professor não deixou fazer isso... Vem cá, vamos conversar, professor, mas ele fez isso, aí a gente tem que fazer toda essa ligação e conversar, é assim, não tem jeito. $\mathrm{O}$ maior problema da gestão são os problemas de relação entre as pessoas. (Direção Escola A - E1).
}

No Quadro 80 apresenta-se o resumo dos entraves ao aperfeiçoamento da educação relativos ao professorado. 
Quadro 80: Fatores que dificultam a melhoria educacional na percepção da comunidade da escola A no quesito Professores e condições de trabalho.

\section{Comunidade da Escola A - Fatores que dificultam a melhoria educacional}

\section{PROFESSORES E CONDIÇÕES DE TRABALHO}

- Desvalorização social e financeira dos professores;

- Formação precária dos professores;

- Resistência em aperfeiçoar a didática e aceitar mudanças;

- Doenças relativas à profissão docente;

- Excesso de alunos por sala.

Entre os fatores facilitadores de um ensino de melhor qualidade foi destacado por um dos coordenadores pedagógicos da escola A: "Professores que procuram trabalhar de maneira/forma interdisciplinar, se capacitam sempre que possível, procuram planejar atividades interessantes e atrativas" (Q2 - Coordenador A). Visão corroborada por um docente que citou que, de acordo com a sua experiência e com a sua vivência em sala de aula, o que precisa ser feito para que se alcance a qualidade almejada é: “1) Formação e qualificação; 2) Dinheiro; 3) Liberdade curricular; 4) Inovações” (Q3 - Docente A).

Segundo os demais docentes atuam como propulsores da educação: ambiente de trabalho adequado, digno e salubre; inovações; formação acadêmica de qualidade; cursos de aperfeiçoamento na área de educação; equilíbrio emocional e boa saúde; além do desenvolvimento de um bom relacionamento com adolescentes.

No Quadro 81, apresentam-se as principais demandas e sugestões para a melhoria educacional na percepção da comunidade da escola A.

Quadro 81: Demandas e sugestões para melhoria da educação na percepção da comunidade da escola A em relação ao quesito Professores e condições de trabalho.

\section{Comunidade da Escola A - Demandas e sugestões para melhoria da educação}

\section{PROFESSORES E CONDIÇÕES DE TRABALHO}

- Ambiente de trabalho adequado, digno e salubre;

- Boa formação acadêmica;

- Cursos de aperfeiçoamento na área de educação;

- Equilíbrio emocional, boa saúde;

- Bom relacionamento com adolescentes;

- Trabalho interdisciplinar e inovador.

Conforme exposto por um docente, entre os principais desafios para a implementação de um Ensino Médio de qualidade estão:

- Curso para gestores voltados par RH Recursos Humanos. Proporcionados pelos tomadores de decisão. E atendimento psicológico para professores pelo menos duas vezes ao ano. São os principais desafios para implantação de um Ensino Médio de 
qualidade. Depois vem a questão dos recursos financeiros - condições mínimas de trabalho; xerox; cópias; pincéis; internet (Q9 - Docente A).

É importante observar que as duas escolas pesquisadas têm um alto índice de alunos satisfeitos e de profissionais que gostam de atuar na escola. O que demonstra que o ambiente de trabalho é agradável e salubre em âmbito geral.

\section{Escola B}

No tocante ao quesito Professores e Condições de Trabalho, em relação aos fatores que dificultam a melhoria do ensino, os coordenadores da escola B apontaram: pouca capacitação ou falta de vontade em compartilhar conhecimentos e vivências em sala de aula, com vistas a motivar o aluno; resistência em melhorar a didática; preconceito remanescente e falta de sensibilidade em relação à realidade dos alunos; falta estimular análises de forma crítica, porém, sem partidarismos - "alguns são alienados quanto à realidade, enquanto outros se preocupam muito mais em defender seus pontos de vista e suas próprias ideologias" (Coordenador B).

Segundo a direção escolar, há muitos professores que resistem em mudar ou aceitar novas propostas pedagógicas. Com intuito de transpor essas barreiras, criou-se o PI (Projeto Interdisciplinar), em algum aspecto semelhante às oficinas adotadas na escola A. De acordo com a direção:

O PI foi uma das formas, porque no princípio a gente tentou, assim, todo mundo, vamos trabalhar o ENEM dentro de sala? Vamos fazer o simulado? Aí muitos professores nem corrigiam o simulado, nem o simulado que é nosso eles corrigiam com o aluno, ué, então para que fez, entendeu? Então a gente precisou dar um passo a mais, então vamos pensar em outra coisa (Direção Escola B, E2).

Quadro 82: Fatores que dificultam a melhoria educacional na percepção dos coordenadores da escola B no quesito Professores.

\section{Comunidade da Escola B - Fatores que dificultam a melhoria educacional}

\section{PROFESSORES}

- Pouca capacitação ou a falta de vontade de compartilhar conhecimentos e vivências em sala de aula;

- Preconceito remanescente e falta de sensibilidade em relação à realidade dos alunos;

- Resistência em aperfeiçoar a didática e aceitar mudanças;

- Falta promover análises críticas sem partidarismos.

Cabe observar que os professores da escola B não sinalizaram aspectos dificultadores relacionados à própria classe docente. Já no tocante aos fatores facilitadores de um ensino de qualidade, os docentes indicaram: um corpo docente interessado, qualificado e motivado, que consiga contagiar os alunos. E que procura conhecer a realidade vivida pelos 
alunos, o que propicia aproximação, empatia e consequentemente, troca mais efetiva. Além do baixo absenteísmo. Os principais relatos nesse sentido apresentam-se a seguir:

A pouca capacitação ou a falta de vontade de alguns professores em dedicar os seus conhecimentos e vivências em sala de aula, com vistas a motivar o aluno. O preconceito remanescente e a falta de sensibilidade dos docentes em relação à realidade dos alunos $(\mathrm{Q} 2$ - Coordenador $\mathrm{B})$;

A falta de observar de forma crítica e sem partidarismos, por parte dos docentes (alguns são alienados quanto à realidade, enquanto outros se preocupam muito mais em defender seus pontos de vista e suas próprias ideologias) em estimular análises e crítica da realidade próxima do seu aluno $(\mathrm{Q} 2$ - Coordenador B);

[...] resistência por parte de alguns professores em mudar sua forma de agir quanto a apresentação do conteúdo proposto (Q2 - Coordenador B);

É necessário que o professor conheça seus alunos de forma a oferecer os conteúdos de forma a atender os anseios e necessidades dos alunos promovendo a esperança $\mathrm{e}$ orientando os alunos de forma que possam alcançar conhecimento que promova seu desenvolvimento e melhorias de suas relações fora da escola (Q3 - Coordenador B);

Apropriação pelos professores do tempo de coordenação para um efetivo trabalho, propiciando assim que o professor não leve trabalho para casa e suas horas de lazer e descanso (Q3 - Coordenador B).

O Quadro 83 apresenta um resumo dos fatores relativos ao professorado, apresentadas pela comunidade escolar B, que influem para a melhoria da educação.

Quadro 83: Demandas e sugestões para melhoria da educação na percepção da comunidade da escola B em relação ao quesito Professores.

\section{Comunidade da Escola B: Demandas e sugestões para melhoria da educação}

PROFESSORES E CONDIÇÕES DE TRABALHO

- Interessado, qualificado, motivado, que consiga contagiar os alunos;

- Trabalho conjunto;

- Busque conhecer melhor o aluno, suas realidades e aspirações;

- Procure se aperfeiçoar;

- Se mantenha atualizado em relação às tecnologias inovadoras;

- Incentivar a leitura e interpretação de textos;

- Baixo absenteísmo.

\section{Escolas A e B}

Em síntese, contrastaram-se as opiniões das duas comunidades pesquisadas em relação ao tópico Professores e Condições de Trabalho. Os resultados referentes aos fatores que dificultam a implementação de uma educação de melhor qualidade, reportados pelos participantes, assim como as demandas e as sugestões expostas, estão apresentados nos Quadros 84 e 85, a seguir. 
Quadro 84: Fatores que dificultam a melhoria educacional na percepção das comunidades escolares A e B em relação ao quesito Professores e Condições de Trabalho.

\begin{tabular}{|c|c|c|}
\hline & ESCOLA A & ESCOLA B \\
\hline \multirow{4}{*}{ 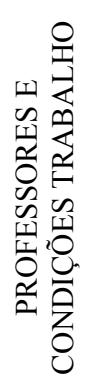 } & $\begin{array}{l}\text { Desvalorização social e financeira dos } \\
\text { professores. }\end{array}$ & Desvalorização dos docentes. \\
\hline & Formação precária dos professores. & $\begin{array}{l}\text { Pouca capacitação ou a falta de vontade de } \\
\text { compartilhar conhecimentos e vivências em sala } \\
\text { de aula. }\end{array}$ \\
\hline & $\begin{array}{l}\text { Resistência em aperfeiçoar a didática e aceitar } \\
\text { mudanças. }\end{array}$ & $\begin{array}{l}\text { Resistência em aperfeiçoar a didática e aceitar } \\
\text { mudanças. }\end{array}$ \\
\hline & Excesso de alunos por sala. & Alto número de estudantes por sala. \\
\hline
\end{tabular}

Quadro 85: Demandas e sugestões para melhoria da educação na percepção das comunidades escolares A e B em relação ao quesito Professores e Condições de Trabalho.

\begin{tabular}{|c|c|c|}
\hline & ESCOLA A & ESCOLA B \\
\hline \multirow{4}{*}{ 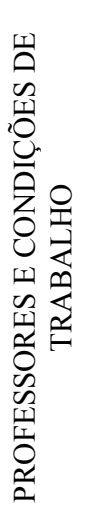 } & $\begin{array}{l}\text { Ambiente de trabalho adequado, digno e } \\
\text { salubre. }\end{array}$ & $\begin{array}{l}\text { Condições de trabalho adequado. Trabalho } \\
\text { conjunto. }\end{array}$ \\
\hline & $\begin{array}{l}\text { Boa formação acadêmica; cursos de } \\
\text { aperfeiçoamento na área de educação. Trabalho } \\
\text { interdisciplinar e inovador. }\end{array}$ & $\begin{array}{l}\text { Procure se aperfeiçoar; se mantenha atualizado } \\
\text { em relação às tecnologias inovadoras; } \\
\text { Interessado, qualificado, motivado, que consiga } \\
\text { contagiar os alunos. }\end{array}$ \\
\hline & Bom relacionamento com adolescentes. & $\begin{array}{l}\text { Busque conhecer melhor o aluno, suas } \\
\text { realidades e aspirações. Coibir preconceito } \\
\text { remanescente e falta de sensibilidade em relação } \\
\text { à realidade dos alunos. }\end{array}$ \\
\hline & Equilíbrio emocional, boa saúde. & Diminuição do absenteísmo. \\
\hline
\end{tabular}

\subsubsection{Alunos}

No tocante aos alunos, um aspecto bastante destacado nas duas comunidades pesquisadas foi o desinteresse dos estudantes pela escola, no relato de um docente: “o desinteresse dos alunos, que se mostram inalcançáveis", isso corrobora com a demanda de ambas as comunidades escolares de aperfeiçoamento e flexibilização do currículo do Ensino Médio, de modo a torná-lo mais atrativo aos estudantes; assim como a necessidade de desenvolvimento de práticas pedagógicas estimulantes ao público. Como pontuou um coordenador pedagógico da escola $\mathrm{B}$, é preciso:

[...] respeito às necessidades dos alunos e trabalhar sempre com o conteúdo programático aliado às experiências de vida e realidade dos alunos (Q2 Coordenador B). 


\section{Escola A}

Além do desinteresse pelos estudos, outros aspectos indicados pelos docentes da escola A, que dificultam o desenvolvimento de uma aula mais qualitativa estão: falta de hábito de estudar; carência de material e uso abusivo de celular em sala de aula. Aspecto que requer atenção não só dos gestores educacionais, como também das famílias, nas quais os hábitos são desenvolvidos, e, por vezes, validados.

Para um dos coordenadores, há falta de compromisso dos estudantes com os estudos. Já para a direção escolar, "tem muito aluno que chega do ensino fundamental sem a qualificação, aí ele vê que no Ensino Médio e está apanhando mais ainda..., e aí sai para trabalhar" (Direção Escola A - E1). Segundo a direção, os alunos vão para o mercado de trabalho por necessidade, às vezes por ter constituído família. Esclarece, ainda, que esse é um dos motivos da evasão escolar no Ensino Médio.

No Quadro 86 apresenta-se um resumo dos entraves ao aperfeiçoamento da educação relativos ao público discente.

Quadro 86: Fatores que dificultam a melhoria educacional na percepção da comunidade da escola A no quesito Alunos.

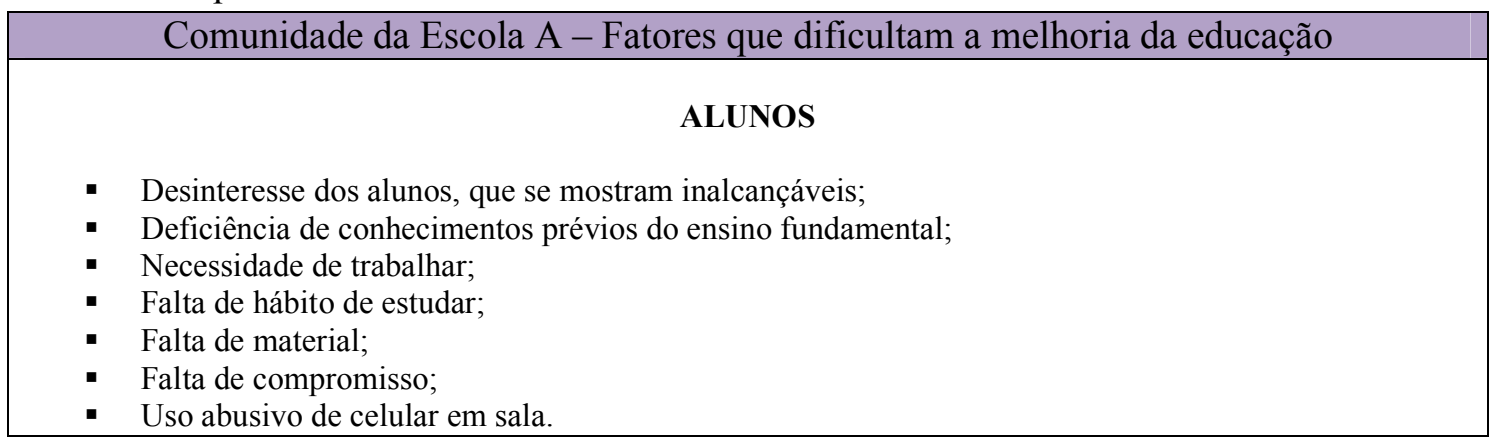

Entre as principais demandas e sugestões apresentadas pelos docentes da escola A, no tocante aos alunos, estão:

Criar no aluno o desejo de estudar, aprender, ouvir, respeitar etc (Q8 - Docente A);

$1^{\circ}$ falta de pré-requisito (aluno está chegando no Ensino Médio sem saber ler); $2^{\circ}$ Falta de foco de vida - para que serve o Ensino Médio? Se eu não for pra faculdade no que me ajuda certos conteúdos que são meramente acadêmicos? $3^{\circ}$ Foco no processo de ensino aprendizagem / o que é ensinado em relação ao que é avaliado) (Q9 - Docente A);

Hoje, sinceramente, fica claro que os alunos estão desinteressados pela escola. Eles vêm mais à escola para as relações sociais. O celular é um incômodo na hora da aula. Até os pais ligam. Volto nas questões do item 2. O professor precisa estar satisfeito com o seu trabalho e deve ser bem remunerado para realizá-lo (Q9 Docente A). 
Dessa forma, no Quadro 87 apresentam-se os fatores relativos ao público discente que favorecem um ensino de melhor qualidade.

Quadro 87: Fatores que influenciam na melhoria da educação na percepção da comunidade da escola A em relação ao quesito Alunos.

\section{Comunidade da Escola A - Fatores que influenciam na melhoria da educação}

- Alunos preparados para a série;

ALUNOS

- Interesse e motivação para estudar;

- Orientação/motivação sobre objetivo de estudo.

\section{Escola B}

Em relação aos alunos, além do desinteresse dos estudantes, os principais aspectos apontados pelos docentes da escola $\mathrm{B}$, que dificultam o desenvolvimento de uma educação de melhor qualidade foram: a falta de informação a respeito do mercado de trabalho e dos cursos superiores; falta de tempo para estudar em razão da necessidade de trabalhar; dificuldade financeira de uma minoria de alunos da escola B; uso das redes sociais (internet) em sala de aula e indisciplina em algumas turmas. Aspectos resumidos no relato de um docente: "Drogas, pobreza, necessidade de trabalho, falta de base do ensino fundamental. Não identificação do aluno com o ambiente escolar" (Q2 - Docente B).

Uma estratégia encontrada pela escola B, em 2016, para tentar minimizar esse problema de déficit de formação do aluno em relação ao ensino fundamental, foi visitar e conversar com a equipe da escola de onde a maioria dos alunos provém. Essa aproximação tem como intuito compartilhar demandas, conteúdos requeridos do ensino fundamental para que os professores da escola B possam avançar no Ensino Médio; assim como as formas de avaliação aplicadas na escola $\mathrm{B}$, tais como provas multidisciplinares e seminários.

Para a direção escolar, a falta de foco e a diversidade de interesses externos à escola próprios da fase adolescente dificultam a melhoria da aprendizagem.

No Quadro 88 apresentam-se os principais entraves relativos ao público discente apresentados pela comunidade escolar. 
Quadro 88: Fatores que dificultam a melhoria educacional na percepção da comunidade da escola B no Alunos.

\section{Comunidade da Escola B - Fatores que dificultam a melhoria educacional}

\section{ALUNOS}

- Falta de informação dos alunos a respeito do mercado de trabalho e dos cursos superiores;

- Falta de foco;

- Interesses externos à escola;

- Defasagem idade/aluno;

- Falta de tempo para estudar, pois os alunos são cheios de atividades no turno contrário da escola;

- Desinteresse de grande parte alunos nos estudos;

- A realidade vivida por muitos alunos do noturno;

- Uso das redes sociais (internet) durante as aulas;

- Drogas, pobreza, necessidade de trabalho, falta de base do Ensino Médio. Não identificação do aluno com o ambiente escolar;

- O aluno morar longe da escola;

- Necessidade de trabalhar;

- Indisciplina em algumas turmas;

- Dificuldade financeira de uma minoria de alunos.

Ainda em relação aos alunos, conforme apresentado no Quadro 88, os docentes da escola B pontuaram cinco aspectos relacionados a eles que propulsionam o ensino de melhor qualidade, quais sejam: maturidade e vontade de aprender; base sólida do ensino fundamental, com capacidade em interpretação de textos; aluno que saiba o curso que pretende realizar na faculdade, a profissão na qual quer atuar; atualizado em relação a notícias e acontecimentos no mundo, além da diversidade de alunos, o que propicia a troca de visão, experiência e conhecimentos.

Para a direção, propicia a aprendizagem: incentivo, muito diálogo sobre a importância do estudo; base familiar que valide esse olhar, que valorize e dê suporte aos estudos. Entre os relatos estão:

A grande chave é motivar e despertar o interesse do aluno(a) para que inclusive ele busque por meios próprios e complementares aprender os conteúdos que não viu. $\mathrm{O}$ aluno tem que ter bem claro o que o motiva a estar no espaço escolar. Ele é o protagonista (Q3 - Docente B);

Acredito que deve haver mudança na mentalidade dos alunos; professores especializados e motivados alcançam poucos resultados com alunos desinteressados, que vão para a escola sem motivação, sem vontade de aprender. Mesmo com aulas motivadoras encontramos dificuldades em observar uma resposta positiva por parte dos alunos (Q3 - Docente B);

A maior dificuldade, como já disse, é trazer os alunos para dentro da escola, fazê-los entender que, com estudo, eles podem almejar algo mais, que a escola é um ambiente de transformação e não um lugar para passar tempo por não ter outra coisa pra fazer (Q9 - Docente B).

A gente conversa com alunos, que através da educação, através do ensino, através da escola que ele vai ter alguma chance de melhoria no sistema de trabalho, melhoria de vida, através daqui [...] A maioria dos pais dos nossos alunos são pais que não tiveram acesso à educação, [...] são pais que estão estudando agora então, depois de 
alguns anos estão ingressando na universidade, então isso aí tudo estão vendo, e aí por aí eles também, apesar de não ser uma aula tão interessante eles persistem (Direção Escola B - E2).

Quadro 89: Fatores que influenciam na melhoria da educação na percepção da comunidade da escola B em relação ao quesito Alunos.

\section{Comunidade da Escola B: Fatores que influenciam na melhoria da educação}

\section{ALUNOS}

- Maturidade e vontade de aprender;

- Formação sólida do ensino fundamental;

- Questão cultural e base familiar;

- Diálogo e incentivo;

- Definição por parte do aluno do curso que pretende fazer na faculdade ou a profissão que irá atuar;

- Acesso a notícias e acontecimento s do mundo;

- Diversidade.

\section{Escolas A e B}

Em síntese, contrastaram-se as opiniões das duas comunidades pesquisadas em relação ao tópico Alunos. Os resultados apresentam-se nos Quadros 90 e 91, os quais indicam, respectivamente, os fatores que dificultam a implementação de uma educação de melhor qualidade, reportados pelos participantes, assim como as demandas e as sugestões expostas.

Quadro 90: Fatores que dificultam a melhoria educacional na percepção das comunidades escolares A e B em relação ao quesito Alunos.

\begin{tabular}{|l|l|l|}
\hline \multicolumn{1}{|c|}{ ESCOLA A } & \multicolumn{1}{c|}{ ESCOLA B } \\
\hline \multirow{2}{*}{$\begin{array}{l}\text { Desinteresse dos alunos, que se mostram } \\
\text { inalcançáveis; falta de hábito de estudar; Falta de } \\
\text { compromisso; falta de material. }\end{array}$} & $\begin{array}{l}\text { Desinteresse de grande parte alunos nos estudos. } \\
\text { Falta de foco; Interesses externos à escola; } \\
\text { Defasagem idade/aluno. Não identificação do } \\
\text { aluno com o ambiente escolar; Falta de } \\
\text { informação dos alunos a respeito do mercado de } \\
\text { trabalho e dos cursos superiores. }\end{array}$ \\
\cline { 2 - 3 } & $\begin{array}{l}\text { Deficiência de conhecimentos prévios, do ensino } \\
\text { fundamental. }\end{array}$ & Falta de base do ensino fundamental. \\
\cline { 2 - 3 } & Necessidade de trabalhar. & $\begin{array}{l}\text { Drogas, pobreza, necessidade de trabalhar. } \\
\text { Dificuldade financeira de uma minoria de alunos. } \\
\text { Falta de tempo para estudar, pois os alunos são } \\
\text { cheios de atividades no turno contrário da escola; } \\
\text { A realidade vivida por muitos alunos do noturno. }\end{array}$ \\
\cline { 2 - 3 } & $\begin{array}{l}\text { Uso de celular em sala. } \\
\text { Uso das redes sociais (internet) durante as aulas. } \\
\text { Uso abusivo de celular. }\end{array}$ \\
\hline
\end{tabular}


Quadro 91: Demandas e sugestões para melhoria da educação na percepção das comunidades escolares A e B em relação ao quesito Alunos.

\begin{tabular}{|c|c|c|}
\hline & ESCOLA A & ESCOLA B \\
\hline \multirow[b]{2}{*}{ 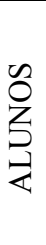 } & Alunos preparados para a série. & Formação sólida do ensino fundamental. \\
\hline & $\begin{array}{l}\text { Interesse e motivação para estudar. } \\
\text { Orientação/motivação sobre objetivo de estudo. }\end{array}$ & $\begin{array}{l}\text { Maturidade e vontade de aprender. Definição por } \\
\text { parte do aluno do curso que pretende fazer na } \\
\text { faculdade ou a profissão que irá atuar. Diálogo e } \\
\text { incentivo. Acesso a notícias e acontecimento s do } \\
\text { mundo. Incentivo familiar. }\end{array}$ \\
\hline
\end{tabular}

\subsubsection{Família}

Apesar de o tema família ter sido, de certo modo, pouco exposto pelos participantes da pesquisa, trata-se de um aspecto que interfere para o êxito escolar do estudante. Cada qual com o seu papel, a família tem responsabilidade na promoção de uma educação escolar de melhor qualidade. Como previsto na Carta Magna, a educação é dever não só do Estado, como também da família (BRASIL, 2016a, art. 205).

\section{Escola A}

Em relação ao quesito Família, tanto um docente como a direção da escola $\mathrm{A}$ expos como fator que dificulta o aperfeiçoamento da educação escolar a falta integração entre a escola e família, conforme apresentado no Quadro 92.

Quadro 92: Fator que dificulta a melhoria educacional na percepção de docente da escola A no quesito Família.

\section{Comunidade da Escola A - Fatores que dificultam a melhoria educacional}

\section{FAMÍLIA}

- Falta de integração entre escola e família.

Um docente indicou como aspecto que facilita a implementação de um Ensino Médio de melhor qualidade o "compromisso das famílias com o acompanhamento o aluno" (Q2 - Docente A). Como mencionado por outro docente "A escola é uma parte dessa formação [integral]. A família e as outras instituições devem fazer a sua [parte]” (Q9 Docente A). 
Visão corroborada pelo coordenador da escola, que expõe que: "A escola assume responsabilidades que seriam da família, assim está sobrecarregada. Os problemas sociais estão presentes e cada dia aumentam" (Q1- Coordenador A).

Entre as principais demandas e sugestões apresentadas pela comunidade escolar A no tocante a Família, conforme exposto no Quadro 93, está criar formas de aproximar e integrar as famílias ao trabalho desenvolvido na escola. E, segundo outro docente, entre os principais desafios para a melhoria da qualidade educacional escolar é a "participação das famílias no processo de formação dos alunos" (Q9 - Docente A).

Quadro 93: Fatores que propiciam a melhoria da educação na percepção da comunidade da escola A em relação ao quesito Família.

\section{Comunidade da Escola A - Fatores que propiciam a melhoria da educação}

\section{FAMÍLIA}

- Maior integração família/escola;

- Participação das famílias no processo de formação dos alunos;

- Compromisso das famílias com o acompanhamento do aluno;

- Conscientização dos pais sobre seus papéis na educação dos filhos;

- Colaboração dos pais com a escola.

\section{Escola B}

Do ponto de vista de docentes da escola $\mathrm{B}$, a falta de participação dos pais na educação escolar do filho e a não integração das famílias com o processo desenvolvido na escola, tornam difícil a melhoria da qualidade educacional. Para um deles, educação de qualidade é:

Aquela que é exercida de forma compartilhada - onde a escola e a família levem o educando a se sentir parte do processo. O acompanhamento da família, o conhecimento das realidades do aluno pela escola e o Estado com políticas que promovam os meios necessários para que o processo ensino/aprendizagem estimule o aluno a querer ir para escola (Q1- Docente B).

Outra aspecto relatado, que prejudica o desenvolvimento das aulas e que a família contribui, refere-se ao uso de telefone celular pelo aluno. Segundo o docente: "O celular é um incômodo na hora da aula. Até os pais ligam." (Q9 - Docente A). O Quadro 94 resume os aspectos em que a família prejudica a melhoria educacional.

Segundo a direção escolar, na escola B o problema maior tem sido em relação aos novos alunos, provenientes de escolas particulares. Segundo a dirigente, o comportamento 
desses alunos tem afetado, inclusive, a educação dos demais alunos. Conforme relatou, além de muito desfocados:

Porque eles acham a escola super fácil, que aqui passam, eles estão querendo tocar o horror. E o pai está querendo mandar dentro da escola, porque a mãe me liga: "ah, vou viajar para os Estados Unidos duas semanas na época da prova o que a senhora pode fazer?" Nada, vai amargar aquilo que ele está escolhendo. É uma questão de escolha, você entendeu, e aí os outros que já não são muitos focados veem isso, infelizmente adolescente ele não acompanha aquele que quer estudar para caramba, ele acompanha o mais fácil, não é? Então a gente está tendo muito problema esse ano com o terceiro ano, muito problema, nossa, está dando problema demais, a gente reúne com os pais, Conselho focado nisso, eu estou mais em sala do que nunca. [...] Um professor entrou aqui esses dias e falou: o nosso ENEM esse ano, neste ano, nós vamos ter problemas (Direção Escola B, E2).

Com isso, é possível verificar a responsabilidade das famílias na busca pela melhoria da qualidade da educação. Assim como, o desafio e a complexidade que é gerir e transpor resistências (de parte dos docentes; por vezes, da coordenação pedagógica; de parcela de alunos e famílias) em busca de uma educação de melhor qualidade.

Quadro 94: Fatores que dificultam a melhoria educacional na percepção da comunidade da escola B no quesito Família.

Comunidade da Escola B - Fatores que dificultam a melhoria educacional

\section{FAMÍLIA}

- Não participação dos pais na educação escolar dos filhos;

- A não integração das famílias com o processo desenvolvido na escola;

- A falta de compromisso da família;

- Falta de responsabilidade em relação à educação dos filhos.

Entre os fatores que propiciam uma educação de melhor qualidade, um docente apontou a estrutura familiar que valoriza a cultura escolar e que possui formação mínima em Ensino Médio completo, conforme Quadro 95.

Quadro 95: Fatores que propiciam a melhoria da educação na percepção da comunidade da escola B em relação ao quesito Família.

Comunidade da Escola B: Fatores que propiciam a melhoria da educação

\section{FAMÍLIA}

- Valorização da cultura escolar e integração família-escola;

- Possua Ensino Médio completo. 


\section{Escolas A e B}

Como realizado para os tópicos anteriores, contrastaram-se as opiniões das duas comunidades pesquisadas, cujo resultado apresenta-se no Quadro 96. Cabe salientar que, em análise aos relatos referentes ao quesito Família, verificou-se direta correspondência entre os fatores que dificultam a implementação de uma educação de melhor qualidade, reportados pelos participantes, e as demandas e sugestões sugeridas por eles. Nesse caso, optou-se por apresentar apenas os fatores que embaraçam a melhoria da educação.

Quadro 96: Fatores que dificultam a melhoria educacional na percepção das comunidades escolares A e B em relação ao quesito Família.

\begin{tabular}{|c|c|c|}
\hline & ESCOLA A & ESCOLA B \\
\hline \multirow[b]{2}{*}{ 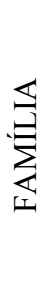 } & Falta de integração entre escola e família. & $\begin{array}{l}\text { A não integração das famílias com o processo } \\
\text { desenvolvido na escola. }\end{array}$ \\
\hline & $\begin{array}{l}\text { Necessidade de participação das famílias no } \\
\text { processo de formação dos alunos. } \\
\text { Falta de compromisso das famílias com o } \\
\text { acompanhamento do aluno e de conscientização } \\
\text { dos pais sobre seus papéis na educação dos filhos. }\end{array}$ & $\begin{array}{l}\text { Não participação dos pais na educação escolar dos } \\
\text { filhos; Falta de responsabilidade em relação à } \\
\text { educação dos filhos. Falta de compromisso da } \\
\text { família. }\end{array}$ \\
\hline
\end{tabular}




\section{CONSIDERAÇÕES FINAIS}

Diante da crise do Ensino Médio vivida no Brasil: 60\% da população com 25 anos ou mais sem essa formação mínima (IBGE, 2015, p. 44); apenas 58\% dos jovens de 15 a 17 anos cursando essa etapa de ensino; mais de 75\% dos estudantes com nível de proficiência abaixo do esperado e $25 \%$ no nível zero, o que significa que não são capazes de aplicar os conhecimentos adquiridos em português e matemática (BRASIL, 2016c); e IDEB estagnado em 3,7 desde o ano de 2011 (INEP, 2016d), o Governo Federal busca alternativas para melhorar a última etapa da Educação Básica, tornada obrigatória pela Emenda Constitucional $n^{\circ} 59 / 2009$.

Na seara da discussão conceitual, como indicamos no decorrer desse estudo sobre qualidade da educação, a literatura apresenta duas vertentes dominantes no que se refere ao debate: uma econômica e uma humanista ou progressiva (FONSECA, 2009; BARRETT et al, 2006). Enquanto a primeira visa à formação para o mercado de trabalho, a segunda busca a formação integral do indivíduo em sociedade, o que não exclui a formação de capital humano.

No campo jurídico, o Brasil tem sinalizado, por meio da legislação vigente, a adoção de um perfil humanista de qualidade educacional. Porém, ainda permanece um grande distanciamento entre as preconizações estabelecidas pelo corpo legislativo nacional e sua efetivação em termos de implementação de políticas públicas.

Com essa compreensão, foi-se a campo investigar a percepção de duas comunidades escolares sobre o que se entende por qualidade em educação, o que se busca nesse sentido, e quais são os principais desafios enfrentados por aqueles que implementam a política de Ensino Médio na ponta, denominados por Lipsky (1980) de "burocratas de nível de rua" e de "burocratas da linha de frente", por Oliveira (2012). Para tanto, selecionamos duas escolas públicas de Ensino Médio, localizadas em Brasília-DF, que se encontram entre as mais bem colocadas no ENEM 2014 e 2015 entre seus pares.

O primeiro resultado da pesquisa permitiu observar coincidência entre as vertentes apresentadas na literatura e em documentos oficiais, com a fala dos profissionais que atuam nas escolas. Do total de profissionais, de ambas as escolas, que participaram da pesquisa (professores, coordenadores pedagógicos e diretores), 53\% enxerga a educação de modo mais amplo, como um meio de se formar cidadãos críticos, conscientes e atuantes no meio onde vivem; 19\% compreende o Ensino Médio como forma de se capacitar para o mercado de trabalho. Para esses, a educação escolar deve focalizar o ENEM e o acesso do aluno à universidade, assim como o alcance de metas e indicadores educacionais nacionais propostos. 
Os demais $28 \%$ apontaram aspectos relacionados aos meios de execução de uma educação de qualidade, tais como boa estrutura, professores capacitados e boa comunicação.

No tocante à correlação entre sucesso no ENEM e qualidade da educação, a percepção de ambas as comunidades escolares pesquisadas seguiu a mesma tendência. A maioria dos alunos (60\%) entende que o sucesso no Exame Nacional do Ensino Médio faz diferença no reconhecimento da qualidade do ensino e da escola. Entre os docentes, observase que houve divisão. Já entre os coordenadores pedagógicos, $80 \%$ sinalizou que o êxito dos alunos no ENEM reflete pouco a educação de qualidade pretendida por eles; para os demais $20 \%$, reflete muito. Em relação aos diretores, um compreende que o sucesso no ENEM reflete uma educação de qualidade enquanto o outro entende que reflete muito, pois garante o ingresso do estudante à universidade.

$\mathrm{Na}$ exposição de motivos sobre essa correlação ou não, os profissionais apresentaram a compreensão de que o ENEM é um importante instrumento avaliativo, o qual possibilita verificar o estado da educação nas unidades escolares. Esse fato vai ao encontro do que preconizam Soares e Xavier no tocante ao "uso dos resultados de rendimento e aprendizado no monitoramento de sistemas de educação básica”, pois é a forma que o Estado tem para saber "se o direito à educação de seus cidadãos está sendo atendido" (SOARES; XAVIER, 2013, p. 905).

No cômputo geral das comunidades escolares houve divisão entre as percepções, visto que $52 \%$ entendem haver correspondência entre o exame e a qualidade educacional, já os demais $48 \%$, compreendem que não. Com isso, foi possível confirmar um dos pressupostos do estudo de que a qualidade medida por avaliação externa, como o ENEM, não corresponde necessariamente à qualidade almejada pelos implementadores na ponta.

Com base na visão de uma formação integral do indivíduo (o que inclui o desenvolvimento de competências para o trabalho e para o exercício da cidadania) e a partir de assuntos da atualidade, as comunidades foram convidadas a externar posição em relação a nove temas: sociedade, direito e cidadania; profissões e trabalho; finanças pessoais e orçamento doméstico; ciência, tecnologia e inovação; autoconhecimento, projeto de vida e solidariedade; meio ambiente e sustentabilidade ambiental; saúde, drogas e sexualidade; arte e cultura e ENEM e vestibulares.

Como resultado, verificou-se haver alinhamento de percepção entre os alunos das duas escolas em relação a todos os itens, ou seja, a porcentagem de respostas para cada item foi muito semelhante e seguiu a mesma tendência. 
Os temas mais indicados por ambas as comunidades escolares (profissionais e alunos) foram "ENEM e vestibulares" e "profissões e trabalho". Isso demonstra, por parte dos estudantes, foco na continuidade dos estudos escolares e a necessidade de definição de profissão e trabalho, inerente a essa fase de vida.

Curioso verificar que temas de certo modo relacionados à profissão, como "autoconhecimento, projeto de vida e solidariedade" e "finanças pessoais e orçamento doméstico" foram apontados com relevância por apenas um terço do alunado.

No quesito "arte e cultura", é curioso que as equipes profissionais demandaram mais do que os próprios alunos. Apontado por quase metade dos estudantes de ambas as escolas do DF. O interesse dos alunos demonstrado nos tópicos "ENEM e vestibulares" e "Profissões e trabalho", sinaliza possíveis razões para esse fato.

Entre os profissionais da escola A, os principais temas apontados na pesquisa foram: "sociedade, direito e cidadania (estudo e resolução de problemas do cotidiano e do entorno da escola" e "ciência, tecnologia e inovação". Esses tópicos receberam indicações de $41 \%$ e $46 \%$ dos estudantes da escola A, respectivamente.

Ainda com foco na formação integral, buscou-se verificar, de forma incipiente, se aspectos da educação socioemocional, tema atual sobre as competências requeridas para o século 21 (ABED, 2014; FÓRUM INTERNACIONAL, 2014), estão sendo trabalhados na prática nas escolas pesquisadas. $\mathrm{Na}$ análise dos dados, de modo geral, 50\% dos estudantes de ambas as escolas sentem que são incentivados frequentemente ou sempre a perseguir um futuro melhor, a superar desafios, a ser perseverante nos seus objetivos, cooperativo, criativo, inovador. Visão correspondente a dos coordenadores pedagógicos da escola A. Sentem-se incentivados às vezes, cerca de $40 \%$ dos alunos em geral.

Ambos os dirigentes sinalizaram que a escola sempre estimula a formação socioemocional. Na escola $\mathrm{A}$, em específico, verificou-se que a gincana promovida oportuniza o desenvolvimento de habilidades nesse sentido. Em relação aos docentes, a quem compete o estímulo diretamente, $40 \%$ de ambas as escolas disseram que raramente ou às vezes a escola estimula. Entre os coordenadores pedagógicos da escola $\mathrm{B}$, a quem compete o direcionar de novas práticas na unidade de ensino, dois dos três respondentes indicaram que os alunos são incentivados somente às vezes. Nesse sentido, pode-se depreender da pesquisa que a abordagem socioemocional precisa ser mais bem inserida no planejamento pedagógico, em especial na escola B. 
Além dos temas indicados anteriormente, com vistas a verificar a situação das escolas no tocante aos principais aspectos associados à qualidade, apresentados na literatura especializada, recolhemos informações sobre o posicionamento das comunidades em relação ao ambiente educativo, prática pedagógica, gestão escolar, condições de trabalho, entre outros aspectos.

Em relação ao ambiente educativo/clima organizacional, de modo geral, ambas as comunidades escolares avaliaram o ambiente como acolhedor e bom para o relacionamento entre todos. Cerca de 70\% dos públicos docente e discente, além dos coordenadores e dos dirigentes de ambas as escolas não indicaram necessidade de melhoria nesse aspecto. Constatação confirmada quando cerca de $70 \%$ dos discentes se dizem satisfeitos ou muito satisfeitos com a qualidade do ensino oferecido pelas respectivas escolas.

No tocante à prática pedagógica, do ponto de vista dos estudantes de ambas as escolas, o quesito mais requerido, em média por $75 \%$ do alunado, refere-se à necessidade de se desenvolver aulas mais interativas e estimulantes. Porém, 50\% deles não demandaram espaços onde possam discutir e contribuir para atingir esse objetivo. Do ponto de vista dos professores, cerca de 70\% indicou que é preciso "aperfeiçoar o material de ensino e aprendizagem, incluindo o uso de jogos, softwares educativos, vídeos e internet" (item 3), o que talvez corrobore para tornar as aulas mais estimulantes, como demandam os alunos. Visão alinhada com os dirigentes escolares e com três dos cinco coordenadores pedagógicos participantes da pesquisa.

Para os diretores das duas unidades, a avaliação do estudante e o reforço escolar precisam ser aperfeiçoados. Demanda de metade do alunado de ambas as escolas. Do ponto de vista dos coordenadores pedagógicos, $20 \%$ enxerga a necessidade de se aperfeiçoar as avaliações do aluno e $80 \%$ entende que é preciso melhorar o reforço escolar. Entre os docentes, esses aspectos foram mais indicados entre os profissionais da escola A (média de $60 \%$ ) do que entre os da escola B (média de 35\%).

No que se refere à gestão escolar, de modo geral apresenta-se satisfatória para a maioria. Cerca de $70 \%$ dos alunos e de $60 \%$ dos docentes, ambos da escola A, aprovam a gestão atual. Em relação à escola $\mathrm{B}$, esse índice sobe para $80 \%$ dos públicos discente $\mathrm{e}$ docente. Apesar disso, em relação à necessidade de se "criar espaços onde todos (alunos, direção, professores, funcionários e pais ou responsáveis) possam discutir e negociar as regras de disciplina e encaminhamentos relativos ao andamento da escola" (Q5 - alunos, item 5), entre o público docente, $50 \%$ da escola A e $80 \%$ da escola B apontou essa necessidade. Entre 
os alunos de ambas as escolas, a demanda por esses espaços foi de $40 \%$. Isso revela um aspecto que merece ser observado pelos dirigentes.

No tocante à formação e condições de trabalho dos docentes, dois aspectos principais foram levantados: rotatividade de pessoal e necessidade de capacitação em tecnologia por parte dos profissionais.

A rotatividade dificulta a implementação do PPP, sua consolidação e aperfeiçoamento, como também pode influir negativamente no Índice de Adequação da Formação Docente da escola. De acordo com a direção da escola A, a rotatividade de professores é alta, em seis anos de gestão, poucos continuam na escola. Na escola B, segundo a direção, só em 2015 foram registradas 5 aposentadorias. Fato importante que requer atenção dos gestores públicos. Apesar da constante rotatividade, ambas as escolas não criaram estratégias específicas para recepção dos novos docentes.

Em termos de formação acadêmica e experiência na área, entre os professores da escola A, que participaram da pesquisa, 70\% concluiu ou cursa especialização, mestrado ou doutorado e $77 \%$ possui mais de dez anos de experiência na área. Porém, somente $31 \%$ trabalha na escola há mais de 3 anos, o que confirma a rotatividade de pessoal. Na escola $\mathrm{B}$, por sua vez, $86 \%$ dos docentes que participaram da pesquisa concluiu ou cursa especialização ou mestrado e 93\% possui mais de dez anos de experiência na área. Entre os participantes, $60 \%$ trabalha na escola $\mathrm{B}$ há mais de 3 anos, o que é favorável ao aperfeiçoamento pedagógico na escola.

No tocante aos cursos de aperfeiçoamento, o Governo do Distrito Federal oferece cursos por meio da Escola de Aperfeiçoamento dos Profissionais da Educação (EAPE), o que exige o deslocamento dos educadores do local de trabalho. Nesse sentido, registra-se demanda apresentada por docentes para que a capacitação ocorra na escola onde atuam. Essa alternativa tem vantagens e desvantagens. Possibilita capacitar um maior número de membros da equipe escolar sobre um determinado tema, o que incentiva alinhamento de percepções dos profissionais para a resolução ou aperfeiçoamento de determinada área, além do não deslocamento dos profissionais para realizar a formação. Porém, entre as desvantagens está a restrição de troca de informações e experiências entre profissionais de diversas escolas.

Um caminho do meio seria a promoção de algumas capacitações na própria unidade de ensino, mais particularmente aquelas que a equipe, a partir de um diagnóstico, tenha verificado como essencial para o alinhamento dos processos de trabalho na escola. Outras capacitações que envolvem troca de experiências, a exemplo das práticas pedagógicas, mantêm-se como realização externa ao ambiente de trabalho. 
Uma área que requer atenção, apontada por docentes de ambas as escolas, é a capacitação dos profisssionais em tecnologia. Conforme salientaram, não basta disponibilizar recursos tecnológicos nas escolas, é preciso, em paralelo, capacitar e estimular os docentes nesse sentido.

No tocante ao ambiente físico escolar (infraestrutura e recursos), ambas as escolas são relativamente bem estruturadas, arborizadas, possuem laboratórios e biblioteca. A escola A possui 14 salas de aula ambientadas de acordo com a disciplina, as quais atendem cerca de 750 alunos (matutino e vespertino). Todas possuem televisor de 40 polegadas. A escola B possui 10 salas de aula, com as quais atende em média 450 alunos do Ensino Médio (matutino e noturno). No turno vespertino, a escola B oferece o $8^{\circ}$ e o $9^{\circ}$ ano do ensino fundamental.

Nesse quesito, entre os aspectos apontados que requerem atenção do poder público estão o telhado e o acesso à Internet, que atualmente é de baixa velocidade. Em ambas as escolas o telhado é de metal galvanizado, o que aquece muito o ambiente de aprendizado. Com vistas a minimizar esse problema, a escola A instalou ventiladores em cada sala, porém, muitos estão quebrados, por isso, requerem manutenção. A escola B, por sua vez, instalou ar condicionado em cada sala de aula, com auxílio financeiro da APM. Em relação à Internet, a baixa velocidade impossibilita o atendimento de uma turma com 40 alunos no laboratório de informática.

Em termos de infraestrutura, outro aspecto indicado pelos dirigentes e por docentes de ambas as escolas é a carência de um auditório para a realização de eventos maiores, como apresentação de peças de teatro e palestras. Na escola B, há a demanda, ainda, pela cobertura da quadra de esportes.

Entre os principais desafios, demandas e algumas sugestões, apresentados por ambas as comunidades escolares pesquisadas, destacam-se:

No que se refere às políticas públicas, é necessário tornar a educação prioridade dentro dos governos federal e distrital; valorizar a classe docente não só financeiramente, mas também em termos de participação na elaboração das políticas públicas; tornar a escola atual e atrativa aos estudantes; flexibilizar o currículo, de modo a torná-lo compatível com o objetivo de vida do estudante; investir no ensino fundamental para que os alunos venham mais bem preparados para o Ensino Médio; garantir capacitação específica a quem desempenha o papel de coordenador pedagógico; diminuir o número de alunos por sala; aperfeiçoar o sistema de aulas e de avaliação; aumentar e repassar tempestivamente os recursos financeiros; aumentar a autonomia no gasto e na gestão de pessoas e melhorar a área 
administrativa das escolas, tanto em termos de pessoal capacitado, como de sistemas informatizados.

Como destacado por muitos docentes, é premente a necessidade de se fortalecer o ensino fundamental, assim como apoio das famílias para o fortalecimento da escola pública e para a melhoria da formação escolar dos filhos. Não basta uma escola que eduque, motive, discipline, se não há o reforço positivo por parte das famílias no empoderamento da equipe escolar e na orientação dos filhos sobre a importância dos estudos para o seu futuro.

Apontou-se, na pesquisa, a demanda pela reformulação do Ensino Médio, porém, um dos coordenadores pontua que para isso é preciso:

\begin{abstract}
Fazer mais discussões sobre as políticas públicas, estar mais próximos dos professores, gestores de instituições de ensino, administrativos educacionais antes da tomada de decisões, ver a escola como espaço construtor de aprendizagens e letramentos múltiplos importantes na vida social e profissional dos estudantes, portanto, que merecem atenção dos governantes; Entender que, valorizar o profissional de educação é gerar qualidade à educação da população (Q9Coordenador B).
\end{abstract}

Em relação à flexibilização curricular, um docente sugeriu a construção de uma Base Regional Comum, uma etapa prévia à construção da Base Nacional Curricular Comum, que pudesse proporcionar a experimentação de diferentes propostas, antes da definição de uma base nacional comum.

Para além do currículo, o estudo colheu evidências de que é preciso ressignificar a função da escola no contexto da sociedade brasileira. Como apontou um professor em seu discurso, de que são tudo (tios, babás, psicólogos, agentes de trânsito etc.), menos professores. Essa mesma opinião foi expressa por um coordenador pedagógico, que observa que a escola está sobrecarregada com responsabilidades que cabem às famílias. Por fim, de forma mais ampla, observa-se que os profissionais julgam ser necessário repensar o papel da educação escolar no projeto de desenvolvimento do País.

Outro aspecto importante levantado, que requer atenção do Poder Público, referese à necessidade de se conhecer melhor os estudantes e seus anseios. Esta pesquisa evidenciou que nem todos os estudantes almejam cursar ensino superior. Torna-se necessário ampliar as alternativas de ensino, incluindo o ensino técnico e a valorização das profissões não alinhadas com o mundo acadêmico, mas necessárias à vida social (como confeiteiro, estilista, pedreiro, entre tantos outros).

Como se pode perceber, a pauta educacional é, por característica, complexa e repleta de meandros. A diversidade de públicos envolvidos e de perspectivas requer do Estado e da sociedade brasileira abertura para o debate: Que tipo de ensino queremos? Para quê? 
Como viabilizá-lo com eficiência e efetividade? A partir desse tipo de reflexão, podem-se definir caminhos e construir "pontes" entre as diversas alternativas possíveis: ensino técnico, cursos de extensão, entre outros. Caminhos que tornem a escola atrativa, motivadora e um meio não só de aproximar o estudante dos seus objetivos de vida, mas de torná-lo autônomo, crítico, responsável, e parte integrante e colaborativa da sociedade.

No tocante ao quesito planejamento e gestão escolar, ambas as comunidades profissionais afirmam a necessidade de aumento e tempestividade no recebimento das verbas para melhor planejamento e condução das atividades. Ademais, foram destacados os seguintes aspectos: a necessidade de se realizar um pré-diagnóstico do aluno, verificar seus conhecimentos pregressos e suas demandas; de se construir visão compartilhada sobre as metas da escola; e de boa comunicação entre todos e de apoio da direção aos docentes. Entre os fatores que dificultam a melhoria do ensino, os profissionais indicaram a desorganização, ausência de planejamento e de tempo para planejar no início de cada ano letivo e escola desatualizada em relação à tecnologia.

Para ambos os dirigentes, um dos maiores desafios refere-se à gestão de pessoas, seja no alinhamento de percepção com os coordenadores pedagógicos eleitos pelos docentes; seja em relação à resistência de alguns professores em aperfeiçoar a didática e em aceitar novas práticas; ou, ainda, de relacionamento interpessoal entre os membros da equipe ou entre os profissionais e os alunos.

Segundo a direção da escola $\mathrm{B}$, um fator que propicia o aperfeiçoamento da educação é o apoio da Secretaria de Educação (SE) do Governo do Distrito Federal, com a promoção de reuniões mensais para acompanhamento e busca de soluções. E a figura do coordenador intermediário da $\mathrm{SE}$, que visita as escolas para garantir o aperfeiçoamento pedagógico.

Em relação ao tópico coordenação e prática pedagógica, os principais desafios apontados foram: intempestividade no envio dos recursos financeiros, o que prejudica o desenvolvimento das atividades planejadas; currículo não aderente aos objetivos de vida dos estudantes; número alto de alunos por sala de aula; falta de base do ensino fundamental e não conhecimento sobre a realidade sociocultural do aluno.

Para os diretores, como os coordenadores pedagógicos são escolhidos pelos docentes, há o desafio de se alinhar os interesses entre a coordenação e a direção escolar. Segundo eles, dificulta o aperfeiçoamento da educação quando o coordenador não é proativo, não busca extrapolar, melhorar, pesquisar novas metodologias pedagógicas. Como expôs a direção da escola B: "a coordenação é o coração da escola, [...] é que vai ver se o professor 
cumpre o planejamento, [...] se o professor está com alguma dificuldade, qual a dificuldade que ele está, que ferramentas que eu vou ajudá-lo" (Direção Escola B, E2). Por isso, seria desejável que esses profissionais recebessem formação específica para melhor atuar na área, não só em relação a novas práticas pedagógicas e uso de tecnologias, mas também em termos de organização e gestão.

Em referência ao quesito infraestrutura e recursos, dois aspectos principais foram apontados por ambas as equipes escolares: aprimoramento do ambiente tecnológico, como internet de alta velocidade, Datashow, TV e som em cada sala de aula e adequação climática das salas de aula, com ventilador ou ar condicionado, devido o telhado ser de material inadequado. Outros fatores apontados foram: disponibilização de materiais didáticos adequados e inovadores; aumento no número de profissionais, além da manutenção e melhoria da infraestrutura física, tais como a construção de auditório e a cobertura da quadra esportiva no caso da escola B.

Um aspecto destacado por ambas as comunidades escolares refere-se à baixa velocidade da internet disponibilizada, o que impossibilita o atendimento de uma turma de 40 alunos. Isso torna o acesso atual ineficaz e a política pública pouco efetiva nesse aspecto.

No tocante aos professores e às condições de trabalho, os principais desafios relatados para a melhoria do Ensino Médio são: excesso de alunos por sala e conhecer suas realidades e conhecimentos prévios; desvalorização social e financeira dos professores, formação precária e resistência em aperfeiçoar a didática e em adotar práticas novas; assim como doenças relativas ao exercício da profissão. E, conforme sugerido por um docente da escola B: "que as universidades fizessem um trabalho contínuo e de parceria com os professores de Ensino Médio” (Q10 - Docente B).

Em relação aos alunos, o maior desafio apresentado pelas duas comunidades para a melhoria da educação refere-se ao desinteresse dos estudantes pela escola e pelos estudos, os quais se apresentam inalcançáveis, segundo um docente.

Outros aspectos apontados pelos profissionais foram: deficiência de conhecimentos prévios do ensino fundamental; falta de hábito de estudar; necessidade do aluno de trabalhar e uso de celular em sala de aula.

Segundo os profissionais das escolas pesquisadas, há carência de um prédiagnóstico dos alunos, para que as deficiências formativas trazidas pelo estudante da etapa anterior possam ser compreendidas com maior clareza e, assim, incorporadas no planejamento pedagógico e na estratégia de ensino. Isso, enquanto o ensino fundamental não se aperfeiçoa. 
A falta de informação a respeito do mercado de trabalho e de cursos técnicos e superiores dificulta que o estudante tenha visão de futuro. Pontos requeridos pelos alunos ao sinalizarem que gostariam que a escola explorasse mais ou promovesse atividades extracurriculares sobre "profissões e trabalho" e "ENEM e vestibulares". Isso demonstra interesse dos estudantes na continuidade dos estudos escolares e a necessidade de definição da profissão a seguir, inerente a essa fase de vida.

Do ponto de vista dos estudantes, de modo geral houve alinhamento de percepção no que se refere ao que precisa ser feito para se melhorar a qualidade do Ensino Médio. Os aspectos indicados foram: necessidade de se desenvolver aulas mais estimulantes e interativas; aperfeiçoar o material de ensino e aprendizagem, incluindo o uso de jogos, softwares educativos, vídeos e internet e promover ou aperfeiçoar o reforço escolar. Esse último aspecto talvez para diminuir a deficiência trazida do ensino fundamental. Metade dos alunos indicaram que gostariam de contribuir e negociar formas para melhor aprender o conteúdo. Para isso, requer-se que espaços sejam criados nesse sentido.

Em relação à família, os principais desafios apontados para a melhoria educacional referem-se à dificuldade de se aproximar e integrar as famílias ao trabalho desenvolvido na escola; e de compromisso dos pais com o acompanhamento escolar dos filhos. Em especial as famílias cujos alunos são provenientes de escolas particulares.

Por fim, a pesquisa pode demonstrar nuances que apenas quem vivencia a realidade no cotidiano escolar pode apontar. Daí a importância que a burocracia "de nível de rua" (LIPSKY, 1980) ou "da linha de frente" (OLIVEIRA, 2012) possui não apenas na implementação de um Ensino Médio de melhor qualidade, mas também nas etapas de elaboração e de avaliação da política pública educacional. Dessa forma, confirma-se o segundo pressuposto do estudo, de que a burocracia de base possui papel fundamental não apenas na implementação de um Ensino Médio de melhor qualidade como também nas etapas de elaboração e avaliação da política pública educacional.

De modo geral, é notório que o arcabouço legal brasileiro visa garantir formação de melhor qualidade à população, porém, a sua implementação é complexa e requer esforços de múltiplos atores.

Por meio da pesquisa, foi possível verificar ações governamentais voltadas para a melhoria educacional. Uma delas é o Pacto Nacional pelo Fortalecimento do Ensino Médio (PNEM) proposto pelo Governo Federal com suas duas linhas de ação: redesenho curricular e formação continuada dos professores. E, por parte do Governo Distrital, a adesão ao pacto e a 
promoção de reuniões quinzenais e mensais com profissionais das unidades de ensino para acompanhamento e compartilhamento de ideias e resoluções. Além da oferta de cursos aos docentes, por intermédio da EAPE e do acompanhamento pedagógico regular nas escolas, por meio do coordenador intermediário da Secretaria de Educação distrital. Para pesquisas futuras, seria interessante entrevistar, também, esse profissional, assim como o presidente do Conselho Escolar, os quais poderiam trazer contribuições para a melhoria educacional.

Seria desejável o Governo Federal incentivar pesquisas sobre o Ensino Médio em outros países. Oportunidade em aberto com a adoção, em setembro de 2015, dos Objetivos de Desenvolvimento Sustentável das Nações Unidas, cuja agenda estimula cooperação internacional para a formação de professores.

Desejável, também, incentivar pesquisas e integração entre universidades e escolas do Ensino Médio, com vistas à melhoria educacional. Sob dois aspectos: tanto pesquisas teóricas alinhadas à prática, de modo que não só as escolas possam absorver novas metodologias, mas também que a academia possa melhor compreender seu objeto de estudo por meio de quem o executa. Como também, docentes da academia, por área de atuação (linguagens, exatas, humanas e biológicas), interagir com coordenadores pedagógicos e docentes de sua área no Ensino Médio, com vistas a melhor preparar o aluno para a universidade. Respeitadas as proporções e as particularidades, como realizado pela escola B ao procurar a escola de ensino fundamental de onde a maioria de seus alunos provém.

É possível, e provável, que muitos dos desafios vivenciados pelas comunidades escolares estejam sendo criativamente transpostos por profissionais na ponta. Por isso, em termos de gestão, seria desejável que os Governos Federal, Distrital e Municipal viabilizassem, incentivassem ou fortalecessem ações que propiciem a troca de experiências e de informações entre as unidades de ensino. Dessa forma, seria necessário o levantamento de casos exitosos no Brasil e no mundo a serem disseminados no País. Uma forma de se conhecer essas experiências poderia ser com a criação de concursos de inovação para as áreas de: gestão escolar, coordenação pedagógica, metodologias de ensino por disciplina e interdisciplinar, educação socioemocional e para o futuro e para o desenvolvimento sustentável. Premiações voltadas para os estudantes tanto em relação a propostas educacionais inovadoras como em termos de protagonismo juvenil nas escolas, assim como para as APM ou APAAM, com vistas a se incentivar a participação dos pais nas escolas.

Em termos de indicador, seria interessante que o IDEB fosse calculado por unidade de ensino para que a escola pudesse constatar sua contribuição para o IDEB nacional, regional e local, assim como os gestores pudessem focalizar esforços nas unidades que 
demandem maior atenção. Para um acompanhamento mais qualitativo, seria interessante que o IDEB do Ensino Médio fosse calculado com base no ENEM, o qual inclui todas as disciplinas e já é aferido por unidade escolar, ao invés do Saeb, que é aplicado de forma amostral e só afere língua portuguesa e matemática.

A partir da pesquisa, foi possível constatar que a educação escolar de melhor qualidade requer pausas, mudanças no cotidiano dos envolvidos, como o Projeto Re(vi)vendo Êxodos tem propiciado. Requer, também, tempo e reflexão, conexão entre o mundo íntimo e a realidade externa, para que o aluno possa compreender e se apropriar do conhecimento transmitido. Para isso, como as comunidades escolares pesquisadas declararam, e parte demonstrou, requer, acima de tudo, sensibilidade, compromisso, assertividade e determinação tanto da comunidade escolar como dos gestores públicos, distrital e federal. E não por último, requer dos alunos visão de futuro e empenho; e das famílias e da sociedade como um todo, valorização do estudo e participação efetiva nas escolas. Sem isso, a melhoria da qualidade será sempre pontual e precária.

Para pesquisas futuras, acreditamos ser importante a realização de estudos comparativos com vistas a se investigar como se dá a formação escolar de jovens em países desenvolvidos e em desenvolvimento, inclusive no que se refere ao aspecto da formação socioemocional. Pesquisar, também, como é realizada, nesses países, a formação de quem desempenha a função de coordenador pedagógico, assim como seu papel e contribuições para a melhoria da qualidade da educação ofertada ao público juvenil. E, em relação ao financiamento, verificar se a divergência constatada, nessa pesquisa, entre os valores declarados pelos dirigentes das escolas pesquisadas e os números fornecidos pelos Governos Federal e Distrital procede em outras unidades escolares e por qual motivo. Ademais, analisar as razões e as consequências da não regularidade do montante repassado a cada ano às escolas para a gestão de uma educação formal de melhor qualidade. 


\section{REFERÊNCIAS}

ABED, A. L. Z. O desenvolvimento das habilidades socioemocionais como caminho para a aprendizagem e o sucesso escolar de alunos da educação básica. São Paulo:

2014. Disponível em: $<$ http://portal.mec.gov.br/index.php?option=com docman\&view= download\&alias=15891-habilidades-socioemocionais-produto-1-pdf\&category_slug=j unho-2014-pdf\&Itemid=30192>. Acesso em: 13/04/2016.

AÇÃO EDUCATIVA, UNICEF, PNUD, INEP-MEC (coords.). Indicadores da qualidade na educação. São Paulo: Ação Educativa, 2004.

AMARAL, N. C. O Brasil e o Novo PNE: Expansão-Qualidade-Financiamento. In: SEMINÁRIO Associação Nacional de Política e Administração da Educação - ANPAE. Goiânia: ANPAE, 2012. Disponível em: <http://www.anpae.org.br/seminario /ANPAE2012/Textos/NelsonAmaral.pdf>. Acesso em: 28/02/2015.

ARRETCHE, M. Uma contribuição para fazermos avaliações menos ingênuas. In: MOREIRA, M. C. R.; CARVALHO, M. C. B. (Orgs.). Tendências e perspectivas na avaliação de políticas e programas sociais. São Paulo: IEE/PUC SP, 2001.

BARBOSA, A. Salários Docentes, Financiamento e Qualidade da Educação no Brasil.

Educação \& Realidade, Porto Alegre, v. 39, n. 2, p. 511-532, abr.jun. 2014. Disponível em: $<$ http://www.ufrgs.br/edu_realidade>. Acesso em: 14/06/2016.

BARDIN, L. Análise de Conteúdo. Lisboa: Edições 70, 2010.

BARRETT, A. M. et al. The Concept of Quality in Education: a Review of the 'International' Literature on the Concept of Quality in Education. EdQual Working Paper Number 3. UK: University of Bristol, EdQual, 2006. Disponível em:

$<$ http://www.edqual.org/publications/workingpaper/edqualwp3.pdf/at_download/file.pdf>. Acesso em: 15/08/2016.

BARROS, A. R. Desigualdades Regionais no Brasil: natureza, causas, origens e soluções. Rio de Janeiro: Editora Campus, 2011.

BRASIL. Constituição da República Federativa do Brasil de 1988. Brasília: Senado, $2016 \mathrm{a}$.

. Medida Provisória $\mathrm{n}^{\mathrm{o}} 746$, de 22 de setembro de 2016. Institui a Política de Fomento à Implementação de Escolas de Ensino Médio em Tempo Integral, altera a Lei $n^{\circ}$ 9.394, de 20 de dezembro de 1996, que estabelece as diretrizes e bases da educação nacional, e a Lei $n^{\circ} 11.494$ de 20 de junho 2007, que regulamenta o Fundo de Manutenção e Desenvolvimento da Educação Básica e de Valorização dos Profissionais da Educação, e dá outras providências. Diário Oficial da República Federativa do Brasil, Brasília, 23 de setembro de 2016b. Disponível em: <www.planalto.gov.br> Acesso: 07/10/2016.

Exposição de Motivos n ${ }^{\circ}$ 00084/2016/MEC, de 15 de setembro de 2016, à Medida Provisória no 746/2016. Diário Oficial da República Federativa do Brasil, Brasília, 23 de setembro de 2016c. Disponível em: <https://www.planalto.gov.br/ ccivil_03/_Ato2015-2018/2016/Exm/Exm-MP-746-16.pdf>. Acesso: 07/10/2016. 
. Lei ${ }^{\circ} 13.005$, de 25 de junho de 2014. Aprova o Plano Nacional de Educação.

Diário Oficial da República Federativa do Brasil. Brasília: 26 jun. 2014.

. Lei $\mathrm{n}^{\mathrm{o}} 12.711$, de 29 de agosto de 2012. Dispõe sobre o ingresso nas universidades federais e nas instituições federais de ensino técnico de nível médio e dá outras providências. Diário Oficial da República Federativa do Brasil. Brasília: 30 ago. 2012a. Acesso em: 13/03/2016.

. Decreto $n^{0}$ 6.094, de 24 de abril de 2007. Dispõe sobre a implementação do Plano de Metas Compromisso Todos pela Educação. Diário Oficial da República Federativa do Brasil, Brasília, 25 de abril de 2007.

Lei ${ }^{0}$ 10.172, de 9 de janeiro de 2001. Aprova o Plano Nacional de Educação.

Diário Oficial da República Federativa do Brasil, Brasília: 10 jan. 2001.

. Emenda Constitucional $\mathrm{n}^{\circ} 14$, de 12 de setembro de 1996. Diário Oficial da República Federativa do Brasil, Brasília: 13 set. 1996a. Disponível em: $<\mathrm{http}: / / \mathrm{ww}$ w.planalto.gov.br/ccivil_03/constituicao/emendas/emc/emc14.htm>. Acesso em: 02/12/2015.

. Lei no 9.394, de 20 de dezembro de 1996. Estabelece as Diretrizes e Bases da Educação Nacional. Diário Oficial da República Federativa do Brasil, Brasília: 23 dez. 1996b.

Ministério da Educação. Diretrizes Curriculares Nacionais Gerais da Educação

Básica. Brasília: 2013. 565p. Disponível em: <http://portal.mec.gov.br/ind ex.php?option=com_docman\&view=download\&alias $=15548$-d-c-n-educacao-basica-novapdf\&Itemid=30192> . Acesso em: 02/12/2015.

. Ministério da Educação. Ensino Superior: entenda as cotas para quem estudou todo o Ensino Médio em escolas públicas. Perguntas Frequentes. MEC: 2012b. Disponível em: $<$ http://portal.mec.gov.br/cotas/perguntas-frequentes.html $>$. Acesso em: 07/06/2016.

Ministério da Educação. Parecer CNE/CEB no 8, de 5 de maio de 2010. Estabelece normas para aplicação do inciso IX do art. $4^{\circ}$ da Lei no 9.394/1996, que trata dos padrões mínimos de qualidade de ensino para a Educação Básica pública. Aguardando homologação, Brasília, 2010.

BRICS. Declaração de Brasília. II Reunião de Ministros da Educação do BRICS. Brasília, 02 de março de 2015. Disponível em: <http://brics6.itamaraty.gov.br/category-english/21documents/245-deciieducacao $>$. Acesso em: 14/02/2016.

BRYK, A. S.; HERMANSON, K. L. Educational indicator systems: observations on their structure, interpretation and use. Review of Research in Education, Itasca, v. 19, p. 451-484, 1993.

CAVAliERI, A. M. Tempo de escola e qualidade na educação pública. Educ. Soc., Campinas, v. 28, n. 100 - Especial, p. 1015-1035, out. 2007. Disponível em: <http://w ww.cedes.unicamp. br>. Acesso em: 15/12/2015. 
CARREIRA, D.; PINTO, J. M. R. Educação Pública de Qualidade: quanto custa esse direito? São Paulo, 2011. Disponível em: $<$ http://arquivo.campanhaeducacao.org.br/ publicacoes/CAQieducativo_2Edicao.pdf>. Acesso em: 14/02/2015.

COPELLO, M. I. Fundamentos teóricos e metodológicos de pesquisas sobre ambientalização da escola. Pesquisa em Educação Ambiental, [S.1.], v. 1, n. 1, p. 93-110, dez. 2006. Disponível em: $<$ http://www.revistas.usp. br/pea/article/view/300 11/31898>. Acesso em: 15/12/2015.

DAYRELL, J.; CARRANO, P.; MAIA, C. L. (Orgs.) Juventude e Ensino Médio: sujeitos e currículos em diálogo. Belo Horizonte: Editora UFMG, 2014.

DELORS, J. et al. Learning: the treasure within: report to UNESCO of the International Commission on Education for the Twenty-first Century. Paris: UNESCO, 1996.

DENHARDT, R. B. Teorias da Adminsitração Pública. São Paulo: Cengage Learning, 2012.

DISTRITO FEDERAL. Portaria ${ }^{\circ}$ 27, de 18 de fevereiro de 2016a. Dispõe sobre os critérios referentes à atuação dos servidores integrantes da Carreira de Magistério Público do Distrito Federal nas unidades escolares da Rede Pública de Ensino do Distrito Federal e unidades parceiras e à organização dos atendimentos ofertados. Disponível em: $<$ https://www.diariooficialdf.com.br/wp-content/uploads/2016/02/secre taria-de-educacao-do-df-sedf-especificado-criterios-para-atuacao-dos-servidores-da-carreiramagisterio-publico-do-df-retificado.pdf $>$. Acesso em: 14/09/2016.

Censo Escolar - Total de Turmas e Matrículas por Etapa/Modalidade de Ensino em 04 de abril de 2016b. Disponível em: <http://www.cre.se.df.gov.br/ascom/document os/censo/2016_censo_resultado.pdf $>$. Acesso em: 05/10/2016.

DOURADO, L. F.; OLIVEIRA, J. F; SANTOS, C. de A. A qualidade da educação: conceitos e definições. Série Documental. Textos para discussão, Brasília, v. 24, n. 22, 2007.

FONSECA, M. Políticas Públicas para qualidade da educação brasileira: entre o utilitarismo econômico e a responsabilidade social. Cad. Cedes, Campinas, v. 29, n. 78, maio/ago, 2009.

FÓRUM INTERNACIONAL DE POLÍTICAS PÚBLICAS “Educar para as competências do século 21”, 2014, São Paulo. Comunicado de Imprensa. Disponível em:

$<$ http://www.educacaosec21.org.br/foruminternacional2014/wpcontent/uploads/2014/01/comunicado-de-imprensa-f\%C3\%B3rum.pdf $>$. Acesso em: $13 / 04 / 2016$.

FRANCO, M. L. P. B. Análise de conteúdo. Brasília: Plano, 2003.

FREIRE, P. Educação como prática da liberdade. Rio de Janeiro: Paz e Terra, 1989. Pedagogia do oprimido. Rio de Janeiro: Paz e Terra, 2006.

FRIGOTTO, G. Qualidade e quantidade da educação básica: concepções e materialidade. Sinproeste, 2013. Disponível em: <http://www.sinproeste.org.br/wp- 
content/uploads/2013/04/A-QUALIDADE-DA-EDUCAC\%CC\%A7A\%CC\%83OBA\%CC\%81SICA.-TETXO-PARA-A-ESCOLA-DE-GOVERNO-.-SANTACATARINA..pdf>. Acesso em: 16/05/2016.

GADOTTI, M. Qualidade na educação: uma nova abordagem. 1. Ed. São Paulo: Editora e Livraria Instituto Paulo Freire, 2010.

GUSSO, D. A.; OLIVEIRA, L. F. B. de. Trajetória e Desafios da Educação Básica no Brasil. In: Brasil em desenvolvimento 2014: estado, planejamento e políticas públicas. Editores: Leonardo Monteiro Monasterio, Marcelo Côrtes Neri, Sergei Suarez Dillon Soares. Brasília: Ipea, 2014, p. 199-216. Disponível em: <http://repositorio.ipea.gov.b r/bitstream/11058/3583/1/Livro_Brasil\%20em\%20desenvolvimento_2014_Estado\%20planeja mento $\% 20 \mathrm{e} \% 20$ pol $\%$ C3\%ADticas $\% 20$ p $\%$ C3\%BAblicas_v. $\% 201 . p \overline{d f}>$. Acesso em: $22 / 08 / 2016$.

HANUSHEK, E. O futuro do Brasil depende de bons professores e de alunos competitivos. Revista Desafios do Desenvolvimento. Brasília: IPEA, 2013. Ano 10. Edição 77. Disponível em: $<$ http://www.ipea.gov.br/desafios/index.php? option $=$ com_content $\&$ view $=$ article $\&$ id $=2931$ : catid $=28 \&$ Itemid $=23>$. Acesso em: $16 / 05 / 2016$.

IBGE. Pesquisa Nacional por Amostra de Domicílios: síntese de indicadores 2014. Rio de Janeiro: IBGE, 2015. Disponível em: $<$ http://biblioteca.ibge.gov.br/in dex.php/biblioteca-catalogo?view=detalhes\&id=294935> . Acesso em 17/07/2015.

INEP. Resultado ENEM 2012. Brasília, 2013. Disponível em: <http://portal.inep. gov.br/web/ENEM/ENEM-por-escola>. Acesso em: 17/10/2015.

. Nota Técnica: Indicador de Nível Socioeconômico (Inse) das Escolas. Brasília: 2014a. Disponível em: <http://download.inep.gov.br/educacao_basica/ENEM/ENEM por escola/2015/nota tecnica indicador nivel socioeconomico.pdf $>$. Acesso em: $04 / 09 / 2016$.

Nota Técnica $n^{\circ} 020 / 2014$. Indicador de adequação da formação do docente da educação básica. . Brasília: 2014b. Disponível em: <http://download.inep. gov.br/edu cacao_basica/ENEM/ENEM_por_escola/2014/nota_tecnica_indicador_adequa $\% \mathrm{C} 3 \% \mathrm{~A} 7 \% \mathrm{C} 3$ \%A3o_formacao_docente.pdf $>$. Acesso em: 04/09/2016.

Resultado ENEM 2013. Brasília: 2014c. Disponível em: $<$ http://portal.inep. gov.br/web/ENEM/ENEM-por-escola>. Acesso em: 17/10/2015.

. Indicador de Adequação da Formação Docente: número de docentes, por grupo de adequação da formação à disciplina que leciona, segundo escola - ano 2014. Brasília: 2015a.

Resultado ENEM 2014. Brasília: 2015b. Disponível em: <http://portal.inep.

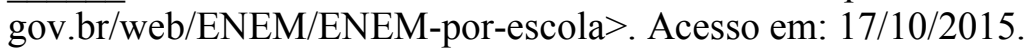

Indicador de Adequação da Formação Docente: número de docentes por grupo de adequação da formação à disciplina que leciona, segundo escola - ano 2015. Brasília: 2016a. 
. Resultado ENEM 2015. Brasília: 2016b. Disponível em: <http://portal.inep.

gov.br/web/ENEM/ENEM-por-escola>. Acesso em: 01/10/2016.

Resultados IDEB. Brasília: 2016c. Disponível em: <http://ideb.inep.

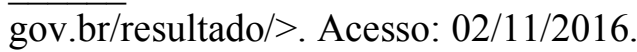

JENSEN, J. L.; RODGERS, R., Cumulating the Intellectual Gold of Case Study Research. Public Administration Review, v. 61, n. 2, p. 235-246, March/April, 2001.

LANGONI, C. Distribuição da renda e desenvolvimento econômico do Brasil. Rio de Janeiro: Expressão e Cultura, 1973.

LEVINE, D. M.; BERENSON, M. L.; STEPHAN, David. Estatística: Teoria e Aplicações usando Microsoft Excel em Português. Rio de Janeiro: LTC, 2000.

LEVIN, J. Estatística Aplicada a Ciências Humanas. 2. Ed. São Paulo: Editora Harbra Ltda, 1987.

LIMA, M. L. O. F.; MEDEIROS, J. J. Empreendedores de políticas públicas na implementação de programas governamentais. Revista de Administração Pública. Rio de Janeiro, v. 46, n. 5, p. 1251-270, set./out. 2012.

LIPSKY, M. Street-level bureaucracy: dilemas of the individual in public services. Nova York: Russel Sage Foundation, 1980.

LOTTA, G. S. O papel das burocracias do nível da rua na implementação de políticas públicas: entre o controle e a discricionariedade. In: FARIA, C. A. (org). Implementação de Políticas Públicas. Teoria e Prática. Belo Horizonte: Editora PUCMINAS, 2012.

LÜDKE, M.; ANDRÉ, M. E. D. Pesquisa em educação: abordagens qualitativas. São Paulo: EPU, 1988.

NAÇÕES UNIDAS. Transformando Nosso Mundo: A Agenda 2030 para o Desenvolvimento Sustentável. 2015. Disponível em: <https://nacoesunidas.org/pos 2015/agenda2030/>. Acesso: 13/05/2016.

NASCIMENTO, P. A. M. M. Recursos destinados à educação e Desempenho Escolar: uma revisão na literatura internacional. Estudos em Avaliação Educacional, v. 18, n. 36, jan./abr. 2007, p. 115 a 137. Disponível em: <http://publicacoes.fcc.org.br/ojs/inde x.php/eae/article/view/2103/2061>. Acesso em: 12/12/2015.

NERI, M. C. O paradoxo da evasão e as motivações dos sem escola. In: VELOSO, Fernando et al. (Orgs.). Educação básica no Brasil: construindo o país do futuro. Rio de Janeiro: Elsevier, 2009. p. 25-50.

OLIVEIRA, A. Burocratas da linha de frente: executores e fazedores das políticas públicas. Revista de Administração Pública, v. 46, n. 6, p. 1551-1573, 2012. 
RIVKIN, S. G.; HANUSHEK, E.A.; KAIN, J. F. Teachers, Schools, and Academic Achievement. Econometrica, v. 73, n. 2 , p. 417-458, 2005. Disponível em: <http: //econ.ucsb.edu/ jon/Econ230C/HanushekRivkin.pdf>. Acesso: 17/09/2015.

ROBERTSON, S. et al. Globalisation, Education and Development: Ideas, actors and dynamics. UK: London, Department for International Development. Robeyns, 2007.

SETÚBAL, M. A. Equidade e desempenho escolar: é possível alcançar uma educação de qualidade para todos? Revista Brasileira de Estudos Pedagógicos (RBEP), Brasília, v. 91, n. 228, p. 345-366, maio/ago. 2010.

SILVA, P. L. B.; MELO, M. A. B. O processo de implementação de políticas públicas no Brasil: características e determinantes da avaliação de programas e projetos. NEPP, caderno 48, UNICAMP-SP, 2000.

SOARES, J. F.; CANDIAN, J. F. O efeito da escola básica brasileira: as evidências do PISA e do SAEB. Revista Contemporânea de Educação, Rio de Janeiro, v. 2, n. 4, p. 1-12, 2007. Disponível em: <http://www.fe.ufrj.br/artigos/n4/numero4-efeito_da_esc ola.pdf>. Acesso em: 10/11/2015.

; XAVIER, F. P. Pressupostos Educacionais e Estatísticos do Ideb. Educ. Soc., Campinas, v. 34, n. 124, p. 903-923, jul.-set. 2013. Disponível em: $<$ http://www.cedes .unicamp. br>. Acesso em: 12/10/2015.

STAKE, R. E. Case studies. In: DENZIN, N. K.; LINCOLN, Y. S. (ed.) Handbook of qualitative research. London: Sage, 2000. p. 435-454.

TAVARES, P. A. Três Ensaios em Economia da Educação. São Paulo-SP: FGV, 2014, 105 f. Tese (Doutorado) - Fundação Getúlio Vargas/Escola de Economia de São Paulo.

TIKLY, L. Towards a framework for understanding the quality of education. EdQual Working Paper No.27, UK: University of Bristol, 2010. Disponível em: <http://www. edqual.org/publications/workingpaper/edqualwp27.pdf>. Acesso em: 02/03/2015.

UNESCO. Relatório de Monitoramento Global 2005 - Educação para todos: o imperativo da qualidade. Editora Moderna. Paris: 2005. Disponível em: $<$ http://unesdoc .unesco.org/images/0013/001390/139079por.pdf>. Acesso em: 17/02/2015.

Relatório de Monitoramento Global de Educação para Todos 2013-2014 -

Ensinar e Aprender: alcançar a qualidade para todos. Paris: 2014. Disponível em: $<$ http://unesdoc.unesco.org/images/0022/002256/225654POR.pdf > . Acesso em: 26/02/2015.

YIN, R. K. Estudo de caso: planejamento e métodos. 2. Ed. Porto Alegre: Bookman, 2001. 
ANEXO 1 - Questionário aplicado aos alunos

Pesquisa: Qualidade do Ensino Médio - Questionário Alunos (nome da escola) $(1 / 12016)$

PERFIL DO ESTUDANTE - TURNO: ( ) MANHÃ

1. Que ano do Ensino Médio você está cursando? ( ) $1^{\circ}$ ano

2. Gênero:

( ) Feminino

( ) Masculino

3. Você trabalha?( ) Não

( ) Sim. Quantas horas por semana?

4. Maior grau de instrução dos seus pais ou responsáveis:

\begin{tabular}{|c|c|c|}
\hline Ensino fundamental & ( ) incompleto & ( ) completo \\
\hline Ensino Médio: & ( ) incompleto & ( ) completo \\
\hline Ensino superior: & ( ) incompleto & ( ) completo \\
\hline Pós-graduação: & ( ) incompleto & ( ) completo \\
\hline
\end{tabular}

QUESTIONÁRIO

1. Qual o seu grau de satisfação com a qualidade do ensino oferecido por essa escola?
( ) Muito insatisfeito
( ) Insatisfeito
( ) Nem satisfeito nem insatisfeito
( ) Satisfeito
( ) Muito Satisfeito

2. Em sua opinião, a escola tem lhe estimulado a perseguir um futuro melhor, a superar desafios, a ser perseverante nos seus objetivos, cooperativo, criativo, inovador?
( ) nunca
( ) raramente
( ) as vezes
( ) frequentemente
( ) sempre

3. Com vistas a uma melhor formação, marque as áreas abaixo que você gostaria que a escola explorasse mais ou promovesse atividades extracurriculares (pode marcar mais de $1 \mathrm{vez}$ ):

( ) Sociedade, direito e cidadania (estudo e resolução de problemas do cotidiano e do entorno da escola)

( ) Profissões e trabalho

( ) Finanças pessoais e orçamento doméstico

( ) Ciência, tecnologia e inovação

( ) Autoconhecimento, projeto de vida e solidariedade

( ) Meio ambiente e sustentabilidade ambiental

( ) Saúde, drogas e sexualidade

( ) Arte e cultura

( ) ENEM e vestibulares

4. Do seu ponto de vista, o sucesso dos alunos dessa escola no ENEM (Exame Nacional do Ensino Médio), nos últimos anos, reflete o que é educação de qualidade para você?
( ) não reflete
( ) reflete pouco
( ) reflete
( ) reflete muito

5. Em sua opinião, o que precisa ser feito para melhorar a qualidade do Ensino Médio nessa escola? (pode marcar mais de 1 vez):

( ) Promover um ambiente educativo mais acolhedor, que favoreça o bom relacionamento entre todos.

( ) Desenvolver aulas mais estimulantes e interativas.

( ) Aperfeiçoar o material de ensino e aprendizagem, incluindo o uso de jogos, softwares educativos, vídeos e internet.

( ) Criar espaços onde os alunos possam discutir, contribuir e negociar formas para melhor aprender o conteúdo.

( ) Criar espaços onde todos (alunos, direção, professores, funcionários e pais ou responsáveis) possam discutir e negociar as regras de disciplina e encaminhamentos relativos ao andamento da escola.

( ) Melhorar a forma de avaliação dos alunos (provas, seminários, pesquisas, elaboração de vídeos etc).

( ) Promover ou aperfeiçoar o reforço escolar para os alunos com nota baixa.

( ) Melhorar a formação dos docentes.

( ) Melhorar a gestão escolar.

( ) Melhorar a infraestrutura física da escola (salas de aula, biblioteca, laboratórios, quadra de esporte etc). 
ANEXO 2 - Questionário aplicado aos docentes

Pesquisa: Qualidade do Ensino Médio - Questionário Docentes (nome da escola)

\section{Caro(a) Professor(a),}

É em respeito ao seu valioso trabalho que este questionário tem como objetivo investigar os principais desafios para a implementação de um Ensino Médio de qualidade no Distrito Federal.

Como você trabalha e contribui em uma escola que obteve uma das melhores notas no ENEM em 2014 entre as escolas públicas no Distrito Federal, a sua participação se torna fundamental. Gostaríamos de "ouvi-lo(a)" sobre os temas abaixo. Com isso, pretendemos dar "voz" àqueles que executam e se esmeram para tornar realidade a política educacional na ponta.

Respeitando os critérios da ética de pesquisa, está assegurado o total anonimato dos participantes. Para qualquer informação a respeito desse estudo você pode entrar em contato com a pesquisadora através do email: pkaari@hotmail.com ou telefone: (61)

Agradeço enormemente por sua contribuição!

Fraterno abraço,

Petra Kaari Fernandes

Mestranda em Gestão Pública FUP/UnB

PERFIL DOCENTE - TURNO: ( ) MANHÃ （ ) TARDE （） NOITE

1. Há quantos anos você atua como professor(a)?
( ) 0 a 5 anos
( ) 5 a 10 anos
( ) acima de 10 anos

2. Desses, quantos anos você atua nessa escola?
( ) menos de 1 ano
( ) de 1 a 2 anos
( ) de 2 a 3 anos
( ) acima de 3 anos

3. Área que leciona:

( ) Linguagens: Língua Portuguesa; Inglês/Espanhol; Artes, Educação Física e Tecnologias da Informação e Comunicação

( ) Ciências da Natureza e Matemática: Biologia; Física, Química e Matemática

( ) Ciências Humanas: História; Geografia; Filosofia e Sociologia

4. Formação acadêmica (grau concluído ou em conclusão):
( ) graduação
( ) especialização
( ) mestrado
( ) doutorado
( ) pós-doutorado

4.1 Na mesma área que leciona? ( ) sim

( ) não

4.2 Possui formação em licenciatura? ( ) sim ( ) não

5. Total de capacitações voltadas à docência realizadas nos últimos 2 (dois) anos:
( ) 0
( ) 1
( ) 2
( ) 3
( ) 4 ou mais

Obs.: Caso queira complementar uma ou mais respostas das questões a seguir, utilize a última página ou solicite mais folhas. 


\section{QUESTIONÁRIO}

1. O que é educação de qualidade para você?

2. Em sua opinião, quais são os principais fatores que facilitam ou dificultam a implementação de um Ensino Médio de qualidade?

Fatores que facilitam:

Fatores que dificultam: 
3. De acordo com a sua experiência e com a sua vivência em sala de aula, o que precisa ser feito para que se alcance essa qualidade?

4. Você gosta de trabalhar nessa escola (o que te motiva)? Por quê? O que poderia melhorar?

5. Em sua opinião, a escola tem estimulado o aluno a perseguir um futuro melhor, a superar desafios, a ser perseverante nos seus objetivos, cooperativo, criativo, inovador?

( ) nunca ( )raramente ( ) as vezes ( ) frequentemente $\quad$ ( ) sempre

De que forma?

6. Com vistas à melhoria da qualidade da educação ofertada, marque abaixo as áreas que deveriam ser enfatizadas ou promovidas atividades extracurriculares na escola:

( ) Sociedade, direito e cidadania (estudo e resolução de problemas do cotidiano e do entorno da escola)

( ) Profissões e trabalho

( ) Finanças pessoais e orçamento doméstico

( ) Ciência, tecnologia e inovação

( ) Autoconhecimento, projeto de vida e solidariedade

( ) Meio ambiente e sustentabilidade ambiental

( ) Saúde, drogas e sexualidade

( ) Arte e cultura

( ) ENEM e vestibulares

( ) Outros. Quais?

7. Do seu ponto de vista, o sucesso dos alunos e da escola no ENEM, nos últimos anos, reflete o que é educação de qualidade para você?

$\begin{array}{lll}(\text { ) não reflete } & (\text { ) reflete pouco } & (\text { ) reflete }\end{array}$

Por quê? 
8. Em sua opinião, o que precisa ser feito para melhorar a qualidade do Ensino Médio nessa escola?

( ) Melhorar o Projeto Político Pedagógico da escola

( ) Melhorar a implementação do Projeto Político Pedagógico

( ) Promover um ambiente educativo mais acolhedor, que favoreça o bom relacionamento entre todos.

( ) Desenvolver aulas mais estimulantes e interativas.

( ) Aperfeiçoar o material de ensino e aprendizagem, incluindo o uso de jogos, softwares educativos, vídeos e internet.

( ) Criar espaços onde os alunos possam discutir, contribuir e negociar formas para melhor aprender o conteúdo.

( ) Criar espaços onde todos (alunos, direção, professores, funcionários e pais ou responsáveis) possam discutir e negociar as regras de disciplina e encaminhamentos relativos ao andamento da escola.

( ) Melhorar a forma de avaliação dos alunos (provas, seminários, pesquisas, elaboração de vídeos etc).

( ) Promover ou aperfeiçoar o reforço escolar para os alunos com nota baixa.

( ) Melhorar a formação dos docentes.

( ) Melhorar a gestão escolar.

( ) Melhorar a infraestrutura da escola. Em que aspecto?

( ) Outras sugestões:

9. Em sua visão e com base em sua experiência, quais são os principais desafios para a implementação de um Ensino Médio de qualidade? 
10. Com vistas a aperfeiçoar a qualidade do Ensino Médio, você gostaria de deixar alguma sugestão aos gestores e aos tomadores de decisão?

Muito obrigada por sua colaboração!! 
ANEXO 3 - Questionário aplicado aos coordenadores pedagógicos

Pesquisa: Qualidade do Ensino Médio - Questionário Coordenador Pedagógico

Caro Docente,

É em respeito ao seu valioso trabalho que este questionário tem como objetivo investigar os principais desafios para a implementação de um Ensino Médio de qualidade no Distrito Federal.

Como você trabalha e contribui em uma escola que obteve uma das melhores notas no ENEM em 2014 entre as escolas públicas no Distrito Federal, a sua participação se torna fundamental para a pesquisa. Gostaríamos de "ouvi-lo(a)" sobre os temas abaixo. Com isso, pretendemos dar "voz" àqueles que executam e se esmeram para tornar realidade a política educacional na ponta.

Respeitando os critérios da ética de pesquisa, está assegurado o total anonimato dos participantes. Para qualquer informação a respeito desse estudo você pode entrar em contato com a pesquisadora através do e-mail: pkaari@hotmail.com ou telefone: (61)

Agradeço enormemente por sua contribuição!

Fraterno abraço,

Petra Kaari Fernandes

Mestranda em Gestão Pública FUP/UnB

ESCOLA:

DATA: 12016.

\section{PERFIL PROFISSIONAL - TURNO:}

1. Há quantos anos você atua como coordenador/supervisor/orientador educacional?

( ) menos de 1 ano ( ) de 1 a $2 \operatorname{anos}$ ( ) de 2 a 3 anos ( ) acima de 3 anos

2. Desses, quantos anos você atua nessa função nessa escola?

( ) menos de 1 ano ( ) de 1 a 2 anos ( ) de 2 a 3 anos ( ) acima de 3 anos

3. Quantos anos de experiência você tem como professor(a), atuando em sala de aula?
( ) menos de 1 ano
( ) de 1 a 5 anos
( ) de 5 a 10 anos
( ) acima de 10 anos

4. Desses, quantos anos você lecionou nessa escola?
( ) nunca lecionei nessa escola
( ) menos de 1 ano
( ) de 1 a 3 anos
( ) de 3 a 5 anos
( ) de 5 a 10 anos
( ) acima de 10 anos

5. Área que lecionava:

6. Formação acadêmica (grau concluído ou em conclusão):

( ) graduação ( ) especialização ( ) mestrado ( ) doutorado ( ) pós-doutorado

7. Total de capacitações relacionadas à educação nos últimos 2 (dois) anos:
( ) 0
( ) 1
( ) 2
( ) 3
( ) 4 ou mais

\section{QUESTIONÁRIO}

(idem ao aplicado aos docentes)

Obs.: Caso queira complementar uma ou mais respostas das questões a seguir, utilize a última página ou solicite mais folhas. 
ANEXO 4 - Questionário aplicado aos diretores

Pesquisa: Qualidade do Ensino Médio

Questionário - Direção Escolar - (nome da escola)

\section{Questões entregues ao entrevistado(a):}

1. Com vistas à melhoria da qualidade da educação ofertada, marque abaixo as áreas que deveriam ser enfatizadas ou promovidas atividades extracurriculares na escola:

( ) Sociedade, direito e cidadania (estudo e resolução de problemas do cotidiano e do entorno da escola)

( ) Profissões e trabalho

( ) Finanças pessoais e orçamento doméstico

( ) Ciência, tecnologia e inovação

( ) Autoconhecimento, projeto de vida e solidariedade

( ) Meio ambiente e sustentabilidade ambiental

( ) Saúde, drogas e sexualidade

( ) Arte e cultura

( ) ENEM e vestibulares

( ) Outros. Quais?

2. Em sua opinião, o que precisa ser feito para melhorar a qualidade do Ensino Médio nessa escola?

( ) Melhorar o Projeto Político Pedagógico da escola

( ) Melhorar a implementação do Projeto Político Pedagógico

( ) Promover um ambiente educativo mais acolhedor, que favoreça o bom relacionamento entre todos.

( ) Desenvolver aulas mais estimulantes e interativas.

( ) Aperfeiçoar o material de ensino e aprendizagem, incluindo o uso de jogos, softwares educativos, vídeos e internet.

( ) Criar espaços onde os alunos possam discutir, contribuir e negociar formas para melhor aprender o conteúdo.

( ) Criar espaços onde todos (alunos, direção, professores, funcionários e pais ou responsáveis) possam discutir e negociar as regras de disciplina e encaminhamentos relativos ao andamento da escola.

( ) Melhorar a forma de avaliação dos alunos (provas, seminários, pesquisas, elaboração de vídeos etc).

( ) Promover ou aperfeiçoar o reforço escolar para os alunos com nota baixa.

( ) Melhorar a formação dos docentes.

( ) Melhorar a gestão escolar.

( ) Melhorar a infraestrutura da escola. Em que aspecto?

( ) Outras sugestões:

Nota 1: Salienta-se que as demais questões aplicadas aos docentes e aos coordenadores pedagógicos foram realizadas por meio de entrevista à direção escolar.

Nota 2: Cumpre informar que se reduziu o tamanho da fonte dos questionários contidos como anexos para que coubessem em menos páginas, porém, os questionários aplicados foram com fonte Times New Roman, tamanho12. 